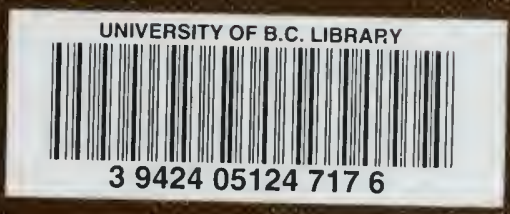

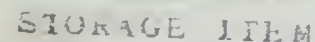
"ROCLSSING-CNE

$L p 1-L \cdot 1.36$ U.B.C. LIBRARY 


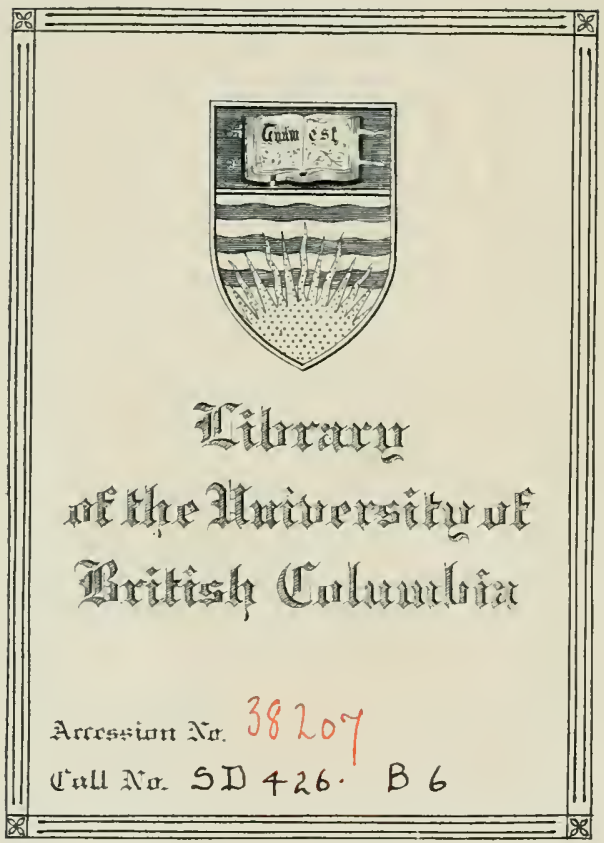



Digitized by the Internet Archive in 2010 with funding from University of British Columbia Library 


\section{OUR NATIONAL FORESTS}




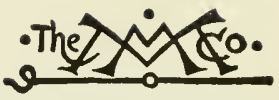

THE MACMILLAN COMPANY

NEW YORK - BOSTON - CHICAGO - DALLAS

ATLANTA - SAN FRANCISCO

MACMILLAN \& CO., Limited

LONDON - BOMBAY - CALCUTTA

MELBOURNE

THE MACMILLAN CO. OF CANADA, LTD. TORONTO 



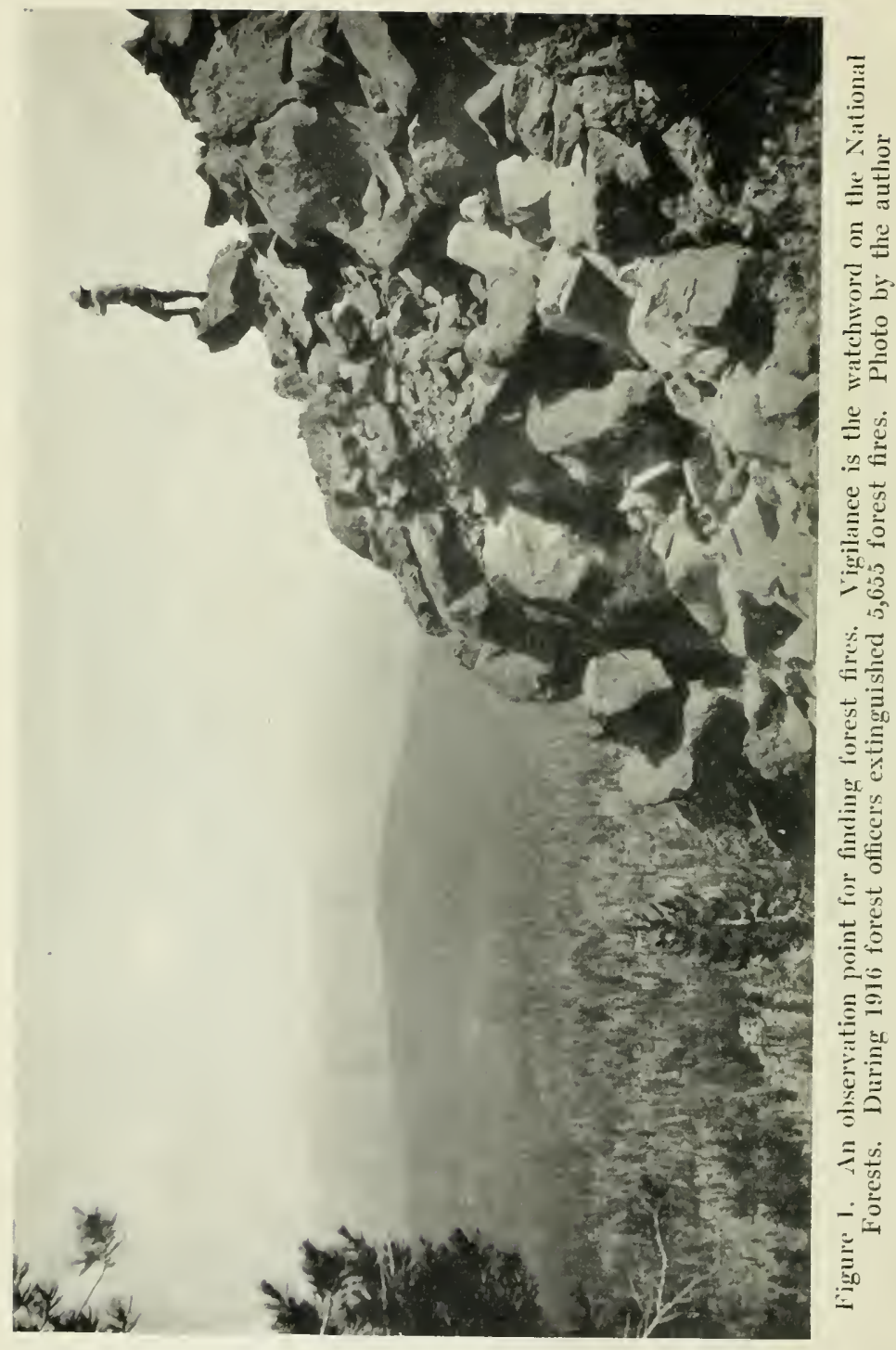




\title{
OUR
}

\section{NATIONAL FORESTS}

A SHORT POPULAR ACCOUNT OF THE WORK OF THE UNITED STATES FOREST SERVICE ON THE NATIONAL FORESTS

BY

RICHARD H. DOUAI BOERKER, M.S.F., Рн.D. Arboriculturist, Department of Parks, City of New York. With the United States Forest Service from 1910 to 1917.

\author{
Jem 吪ark \\ THE MACMILLAN COMPANY \\ 1920 \\ $\Delta$ ll rights reserved
}


COPYRIGHT, 1918

BY THE MACMILLAN COMPANY

Set up and electrotyper. Published, September, 1918 


\section{WHOM should this humble volume}

seek to honor but the father and mother whose unselfish devotion made possible both my education and my profession? $\therefore \therefore \therefore \therefore$ 
The highest type of scientific writing is that which sets forth useful scientific facts in language which is interesting and easily understood by the millions who read.

L. A. Mann. 


\section{PREFACE}

Forestry is a vast subject. It has to do with farm and forest, soil and climate, man and beast. It affects hill and valley, mountain and plain. It influences the life of cities, states, and nations. It deals not only with the manifold problems of growing timber and forest by-products, such as forage, naval stores, tanbark, and maple sugar, but it is intimately related to the navigability of rivers and harbors, the flow of streams, the erosion of hillsides, the destruction of fertile farm lands, the devastation wrought by floods, the game and birds of the forest, the public health, and national prosperity.

The practice of forestry has, therefore, become an important part in the household economy of civilized nations. Every nation has learned, through the misuse of its forest resources, that forest destruction is followed by timber famines, floods, and erosion. Mills and factories depending upon a regular stream flow must close down, or use 
other means for securing their power, which usually are more expensive. Floods, besides doing enormous damage, cover fertile bottom-lands with gravel, bowlders, and débris, which ruins these lands beyond redemption. The birds, fish, and game, which dwell in the forests, disappear with them. Springs dry up and a luxurious, wellwatered country becomes a veritable desert. In short, the disappearance of the forests means the disappearance of everything in civilization that is worth while.

These are the lessons that some of the world's greatest nations have learned, in some cases through sad experience. . The French people, after neglecting their forests, following the French Revolution, paid the penalty. France, through her reckless cutting in the mountain forests, has suffered and is still suffering from devastating floods on the Seine and other streams. Over one million acres were cut over in the mountains, and the slash and young growth that was left was destroyed by fire. As a result of this forest destruction the fertility of over $8,000,000$ acres of tillable land was destroyed and the population of eighteen departments was impoverished or driven out. Now, although over 
$\$ 40,000,000$ has been expended, only a very small part of the damage has been repaired.

Our own country has learned from its own experiences and from the experiences of nations like France. On a small scale we have endured the same devastating floods. Forest fires in the United States have caused an average annual loss of seventy human lives and from $\$ 25,000,000$ to $\$ 50,000,000$ worth of timber. The indirect losses run close to a half a billion a year. Like other nations, we have come to the conclusion that forest conservation can be assured only through the public ownership of forest resources. Other nations have bought or otherwise acquired national, state, and municipal forests, to assure the people a neverfailing supply of timber. For this reason, mainly, our own National Forests have been created and maintained.

The ever-increasing importance of the forestry movement in this country, which brings with it an ever-increasing desire for information along forestry lines, has led me to prepare this volume dealing with our National Forests. To a large extent I write from my own experience, having come in contact with the federal forestry movement for 
more than ten years. My connection with the United States Forest Service in various parts of the West has given me ample opportunity to study every phase of the problem. I am attempting to chronicle a wonderful accomplishment by a wonderful organization of altruistic Americans,--an accomplishment of which every American has reason to feel proud.

Few people realize that the bringing under administration and protection of these vast forests is one of the greatest achievements in the history of forest conservation. To place $\mathbf{1 5 5 , 0 0 0 , 0 0 0}$ acres of inaccessible, mountainous, forest land, scattered through our great western mountain ranges and in eighteen Western States, under administration, to manage these forests according to scientific forestry principles, to make them yield a revenue of almost $\$ 3,500,000$ annually, and to protect them from the ravages of forest fires and reducing the huge annual loss to but a small fraction of what it was before-these are some of the things that have been accomplished by the United States Forest Service within the last twenty years.

Not only is this a great achievement in itself, but few people realize what the solution of the National 
Forest problem has meant to the millions of people who live near them; what it has meant to bring civilization to the great forested empire of Uncle Sam; what it has meant to change from a condition of unrestricted, unregulated misuse with respect to the public domain, to a policy of wise, regulated use, based upon the principle of the greatest good to the greatest number in the long run. In the early days before the Forest Service organization became established, the people were said to have "shot-gun titles" to timber or grazing lands on the public domain, and "might made right" in the truest sense of the word. This crude condition of affairs gave way to wise, conservative use under government control. Just as the farmer each year sets aside a certain amount of his seed for next year's planting, just so the stockman saves his calves and cows and lambs for greater growth and each year sees a part of his herd maturing for market, and just so the forester, under the new system, cuts only the mature trees and allows the young timber to remain for greater growth and greater value in the future, or, in the absence of young trees, plants small trees to replace those removed. The people of the West are convinced that a 
great work has been done well and wisely. The people of the Eastern States will soon realize that a similar forest policy, already inaugurated in the Appalachian and White Mountains, will mean every bit as much to them.

If I succeed only in a small degree to make my reader appreciate the great significance of the $\mathrm{Na}$ tional Forest movement to our national economy, I will feel amply repaid for the time spent in preparing this brief statement. I am indebted to the Forest Service for many valuable illustrations used with the text, and for data and other valuable assistance. To all those who have aided in the preparation of this volume, by reading the manuscript or otherwise, I extend my sincere thanks. I am especially grateful to Mr. Herbert A. Smith and others of the Washington office of the Forest Service for having critically read the manuscript and for having offered valuable suggestions.

\section{Richard H. Doual Boerker.}

New York, N. Y.,

July 7, 1918. 


\section{INTRODUCTION}

\section{FORESTRY AS A NATIONAL PROBLEM}

The forest problem is, both locally and nationally, of vital internal importance. Not only is wood-the chief product of the forest-indispensable to our daily life, but the forest plays an important rôle in regulating stream flow, thereby reducing the severity of floods and preventing erosion. For these reasons the preservation of forests ceases to be a problem of private or individual concern, but forthwith becomes a governmental problem, or, at best, an enterprise which should be jointly controlled by the National Government and the individual States.

Our Consumption of Wood. It is often said that wood enters into our daily life from the time we are born until we die-from the cradle to the coffin. It is difficult to imagine a civilization without wood. In our country in a single year we use $90,000,000$ cords of firewood, nearly 40,000,000,000 feet of lumber, 150,000,000 railroad ties, nearly 1,700,000,000 barrel staves, 445,000,000 board feet of veneer, over $135,000,000$ sets of barrel headings, 
over $350,000,000$ barrel hoops, over $3,300,000$ cords of native pulpwood, 170,000,000 cubic feet of round mine timbers, nearly 1,500,000 cords of wood for distillation, over 140,000 cords for excelsior, and nuarly 3,500,000 telephone and telegraph poles. In short, we take from our forests yearly, including waste in logging and manufacture, more than twenty-two billion cubic feet of wood valued at about $\$ 1,375,000,000$. This is enough lumber to construct seven board walks twenty-five feet wide from the earth to the moon, a distance of about 240,000 miles, or a board walk one-third of a mile wide completely around the earth at the equator. These figures give a little idea of the enormous annual drainage upon the forests of the United States and immediately suggest an important reason that led to the establishment of our National Forests.

The Lumber Industry. Measured by the number of persons employed, lumbering is the country's largest manufacturing industry. In its 48,000 saw mills it employs more than 600,000 men. Its investment in these plants is over $\$ 1,000$,000,000 , and the investment in standing timber is $\$ 1,500,000,000$ more. This industry furnishes 
the railroads a traffic income of over $\$ 200,000$,000 annually. If we include in these statistics also the derived wood products, we find that over $1,000,000$ wage earners are employed, and that the products and derived products are valued at oror $\$ 2,000,000,000$ annually. Most certainly we are dealing with a very large business enterprise.

Our Future Lumber Supply. You may ask, "What effect have the great annual consumption of wood and these large business interests upon the future supply of wood?" The most reliable statistics show that out of 5,200 billion feet of merchantable timber which we once possessed, only 2,900 billion feet are left. In other words, almost half of our original supply of timber has been used. Besides, the present rate of cutting for all purposes exceeds the annual growth of the forests. Even the annual growth is considered by many experts of unknown quantity and quality, to some extent offset by decay in virgin forests. The only logical conclusion to draw from this condition of affairs, if the present rate of consumption continues, is a timber shortage in so far as our most valuable woods are concerned. In view of this it is fortunate that the National Government began to control the 
lumber and forest situation by the creation o National Forests and the institution of scientifi forestry practice.

Forests and Stream Flow. But the forests no only supply us with wood. For other reasons the deserve governmental consideration. The forest in the mountains control our streams, vitally affec the industries depending upon water power, reduc the severity of floods and erosion, and in this wa are intimately wrapped up with our great agricul tural interests. For this reason forestry is by na ture less suited for private enterprise. In agricul ture and horticulture the influence of the farm o the fruit crop rarely extends beyond the owner' fence. What I plant in my field does not affec my neighbors; they share neither in my success o failure. If by the use of poor methods I ruin th fertility of my farm, this fact does not influenc the fertility of my neighbor's fields. But in for estry it is different. Unfortunately, just as th sins of the fathers are visited upon their children so the sins of the mountains are visited upon th valleys.

The mountainous slopes of the Appalachiar ranges and the steep, broken, granite ridges of the 
Rockies, the Sierras, and the Cascades are the sites most suited in our country for forestry purposes. The Appalachian ranges have been affected most by the reckless cutting of forests. When these mountains were clothed with forests, the rivers ran bank full, ships came to the harbors at low tide with ease, and factories and cotton-mills ran steadily all year long. Since the destruction of these forests the surrounding country has suffered from alternate floods and droughts; great manufacturing centers have lost their steady supply of water; harbors are filled with silt from the mountain sides; and fields, once fertile, are covered with sand, gravel, and débrís, deposited by the ungovernable stream. These forests belonged to private individuals who disposed of the timber and pocketed all the profits, while the community below suffered all the loss. In other words, private ownership is inadequate since private interest and private responsibility are not sufficiently far-reaching and far-sighted.

Forests and Erosion. Erosion is one of the most serious dangers that threaten our farms both by transporting fertile soil and by covering the bottomlands with sand, gravel, and débris. Since we are largely an agricultural people, the importance of 
this problem will be readily appreciated. Over 50 per cent. of our population is rural, and the annual production of farm crops has a value of over $\$ 5$,$500,000,000$. Farm uplands are washed away or eroded by high water, and high water is largely caused by the destruction of the forests on the mountain slopes. With the forest cover removed, there is nothing to obstruct the flow of water down the mountain sides. Raindrops beating on the bare soil make it hard and compact so that most of the water runs off instead of being absorbed by the subsoil, with the result that a heavy rain storm rushes down through the valleys in a few days instead of a few weeks, tears out the river banks, floods the lowlands, and deposits upon them the rocks and gravel carried down from the mountains. The most effective means for preventing the erosion and destruction of our farmlands is by the wise use of the forests at the headwaters of the rivers.

Forestry a Public Enterprise. From what has been said it will be seen that forestry is a national business rather than an individual's. Moreover, it is of such a protracted nature, reaching continuously into such long periods of time, demanding so 


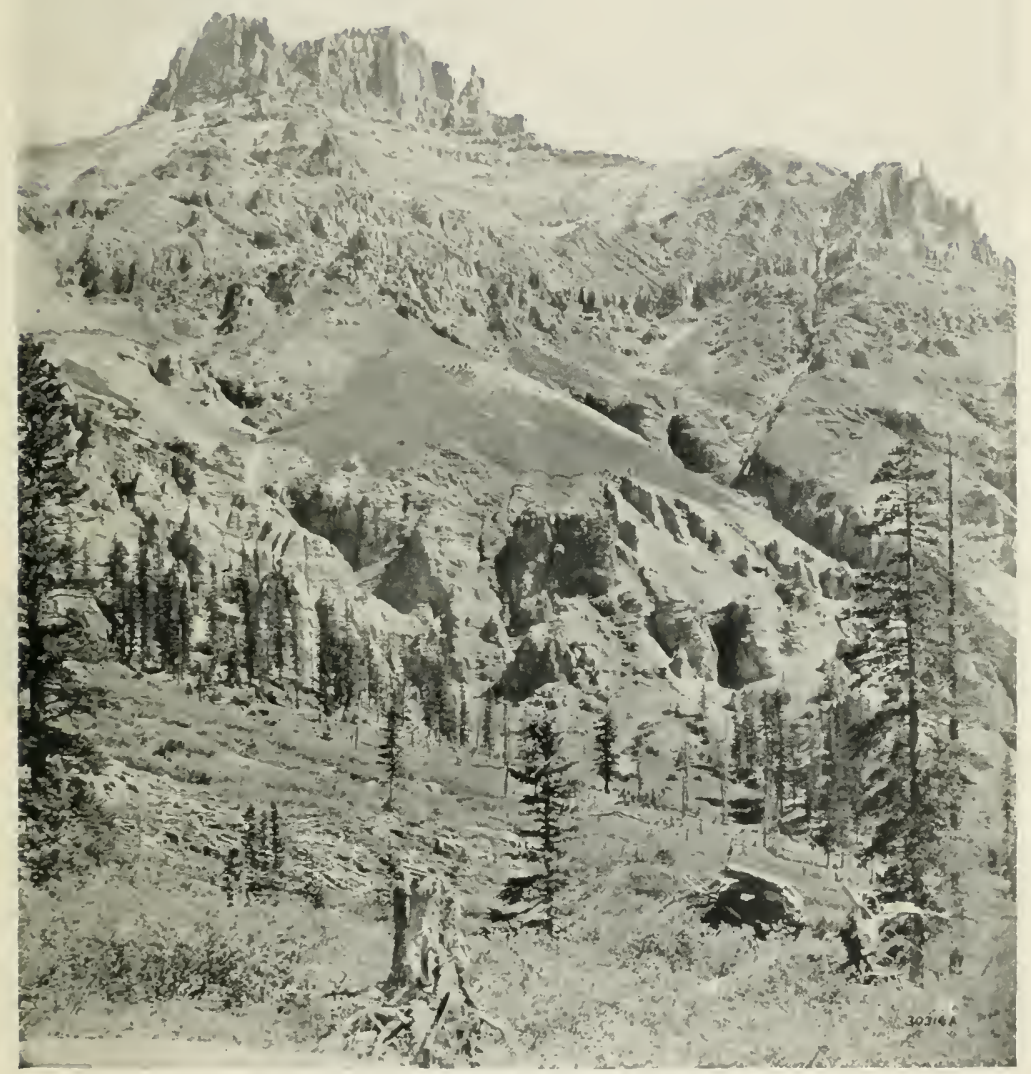

Figure 2. A typical National Forest landscape in the high mountains. Potosi Peak, 13.i63 feet. from Yankee Boy Basin, Lncampalgre National Forest, Ouray County, Colorado. 

many years of time and patience to see the expected and promised results, that an individual would not live to see the success of his labors. The individual becomes easily discouraged and is especially affected by financial conditions. The Government, on the other hand, having unlimited resources at its command can more readily afford to wait for results. In fact every consideration of national welfare urges the Government to carry it on; it is a sure source of revenue, there is none less fluctuating, and it is closely connected with the manifold industries of life. Its chief product is wood, without which the human race, so far, has not succeeded in managing its affairs, and which will therefore always have a sale value.

\section{THE EXTENT AND CHARACTER OF OUR}

NATIONAL FORESTS

How the Government Obtained the National Forest Lands. Probably the first question that will occur to my reader concerning the National Forests is, How did the Government acquire them? To answer this question we have but to turn back the pages of history to the close of the Revolutionary 
War. Following this war, our country started on its career of continental conquest. This conquest was largely a peaceful one because most of the western country was acquired by treaty or purchase, thus: Louisiana Territory was purchased from France in 1803; 'Texas applied for admission into the Union in 1845; Oregon Territory was acquired by treaty from Great Britain in 1846; the present states of California, Nevada, Utah, New Mexico, and Arizona were ceded to us as a result of the Mexican War in 1848; and the Gadsden Purchase was obtained from Mexico in $\mathbf{1 8 5 3}$ and added to the territory of New Mexico. Then also Alaska was finally purchased from Russia in 1867. 'These large acquisitions, comprising together the western two thirds of the United States, were gradually divided into territories. Later they hecame States, and were opened up to settlement and development by means of various land and mining laws and large railroad grants. The National Forests are composed of the land most valuable for growing timber, that has not been acquired in some way by private individuals, in the western part of the United States.

The Romance of the National Forest Region. 
This vast expanse west of the Mississippi River boasts of some of the wildest and most romantic scenery on the North American continent, and it is in the heart of this picturesque country that the $\mathrm{Na}$ tional Forests are located. This is the country in which Owen Wister, Harold Bell Wright, Stewart Edward White, Jack London, Theodore Roosevelt, and other authors have gotten their inspirations and laid their plots. To one who knows "The Virginian," or "When a Man's a Man," or "The Winning of Barbara Worth," or "The Valley of the Moon," nothing more need be said. To others I might say that my pen picture of that country is a very poor and very inadequate method of description. It is the land of the cow-puncher, the sheepherder, and the lumber-jack; a land of crude customs and manners, but, withal, generous hospitality. It is the country of the elk and the mule-tail deer, the mountain lion and the rattlesnake. Its grandeur makes you love it; its vastness makes you fear it; yet there is an irresistible charm, a magic lure, an indescribable something that stamps an indelible impression upon the mind and that makes you want to go back there after you have sworn an oath never to return. 
This National Forest empire presents a great variety of scenery, of forest, and of topography. The beautiful white pine forests of Idaho and Montana, the steep pine- and spruce-clad granite slopes of the Colorado Rockies, and the sun-parched mesas of the Southwest, with their open park-like forests of yellow pine, all have their individual charm. And after crossing the well-watered Cascades and Sierra Nevadas we find forest scenery entirely different. The dense, luxuriant, giant-forests of the coast region of Oregon and Washington, bathed in an almost continual fog and rain, are without doubt the most wonderful forests in the world. And lastly, California, so far as variety of forest scenery is concerned, has absolutely no rival. The open oak groves of the great valleys, the arid pine- and oakcovered foothills, the valuable sugar pine and "bigtree" groves of the moist mountain slopes, and the dwarfed pine and hemlock forests near the serrated crest of the Sierras, all occur within a comparatively short distance of each other, and, in fact, may be seen in less than a day on any one of the many National Forests in these mountains.

Famous Scenic Wonders Near the Forests. 
Many of the beautiful National Parks that have been created by Congress are either entirely or partly surrounded by one or more of the National Forests. These parks are a Mecca to which hundreds of thousands of our people make their annual pilgrimage. Most of these parks are already famous for their scenery, and, in consequence, the National Forests surrounding them have received greater patronage and fame. The Glacier National Park in Montana, the Yellowstone in Wyoming, the Rocky Mountain in Colorado, the Mount Rainier in Washington, the Crater Lake in Oregon, the Wind Cave in South Dakota, and the Lassen Peak Volcanic Park, the Yosemite, General Grant, and Sequoia parks in California, are all situated in the heart of the National Forest region.

The highest and best-known mountain peaks in the United States are either located within or situated near the National Forests, as, for example, Rainier, Olympus, St. Helens, Adams, and Baker in Washington; Hood and Jefferson in Oregon; Shasta, Lassen, and Whitney in California; and Pikes Peak in Colorado.

Then there are the National Monuments, of 
which there are eleven, all situated within one or more of the National Forests. These were created under an act of Congress for the preservation of objects of historic or scientific interest. The largest monument, and no doubt the most famous, is the Grand Canyon National Monument located in the Tusayan and Kaibab National Forests in Arizona, comprising over 800,000 acres. The next largest is the Mount Olympus Monument on the Olympic National Forest in Washington, comprising almost 300,000 acres. Other well-known monuments are the Cinder Cone and the Lassen Peak Monuments on the Lassen National Forest in California, and the Cliff Dwellings on the Gila National Forest in New Mexico.

The Size and Extent of the National Forests. With this brief introduction of the nature of the country in which the National Forests are located, the reader will be interested to know something of the size of the Forests and their total area. The total area varies slightly from time to time, due to the addition of lands that have been found to have value for forestry purposes, or to the elimination of lands found to be chiefly valuable for agricultural use. On June 30, 1917, there were 147 National 
Forests with a total of $155,166,619$ acres. Thus the average National Forest comprises about one million acres of government lands. The many private holdings scattered through the Forests make the average gross area of each Forest much greater. These Forests are located in Alaska, Arizona, Arkansas, California, Colorado, Florida, Idaho, Michigan, Minnesota, Montana, Nebraska, Nevada, New Mexico, North Dakota, Oklahoma, Oregon, Porto Rico, South Dakota, Utah, Washington, and Wyoming. Besides these Forests there have been acquired or approved for purchase under the Weeks Law over 1,500,000 acres in the States of Georgia, Maine, New Hampshire, North Carolina, South Carolina, Tennessee, Virginia, and West Virginia. These lands are now under protection and will gradually be consolidated into National Forests. More lands are constantly being acquired in the Eastern States in accordance with the Weeks Law.

Few people have any conception of what a gigantic empire the National Forest domain is. If consolidated into one large compact area, the 155 million acres of National Forests would cover an area larger than the combined areas of thirteen wellknown Eastern States, viz.: Maine, Vermont, 


\section{INTRODUCTION}

New Hampshire, Massachusetts, Connecticut, Rhode Island, New York, New Jersey, Pennsylvania, Maryland, Delaware, Virginia, and West Virginia (see map). This area is also one fifth larger than the entire area of France. We marvel sometimes at the ability of a ruler to rule a country as large as France or Germany; why should we Americans not marvel at the ability of the man who practically rules over our National Forests, who keeps in perfect working order the great organization which protects and administrates the Forests?

The Topography and Climate of the National Forest Region. The difficulty of the work of this organization is at once apparent when we find that these Forests are located in wild, rugged, mountainous country, in most cases many miles from the railroad and human habitations, such as towns and cities. This country is usually far above sea level - the average being between 3,000 and 8,000 feet in altitude. But there are large areas in the $\mathrm{Na}$ tional Forests of Colorado that lie above 10,000 feet elevation. Such country as this has a very severe climate. The climate is usually too cold and the 


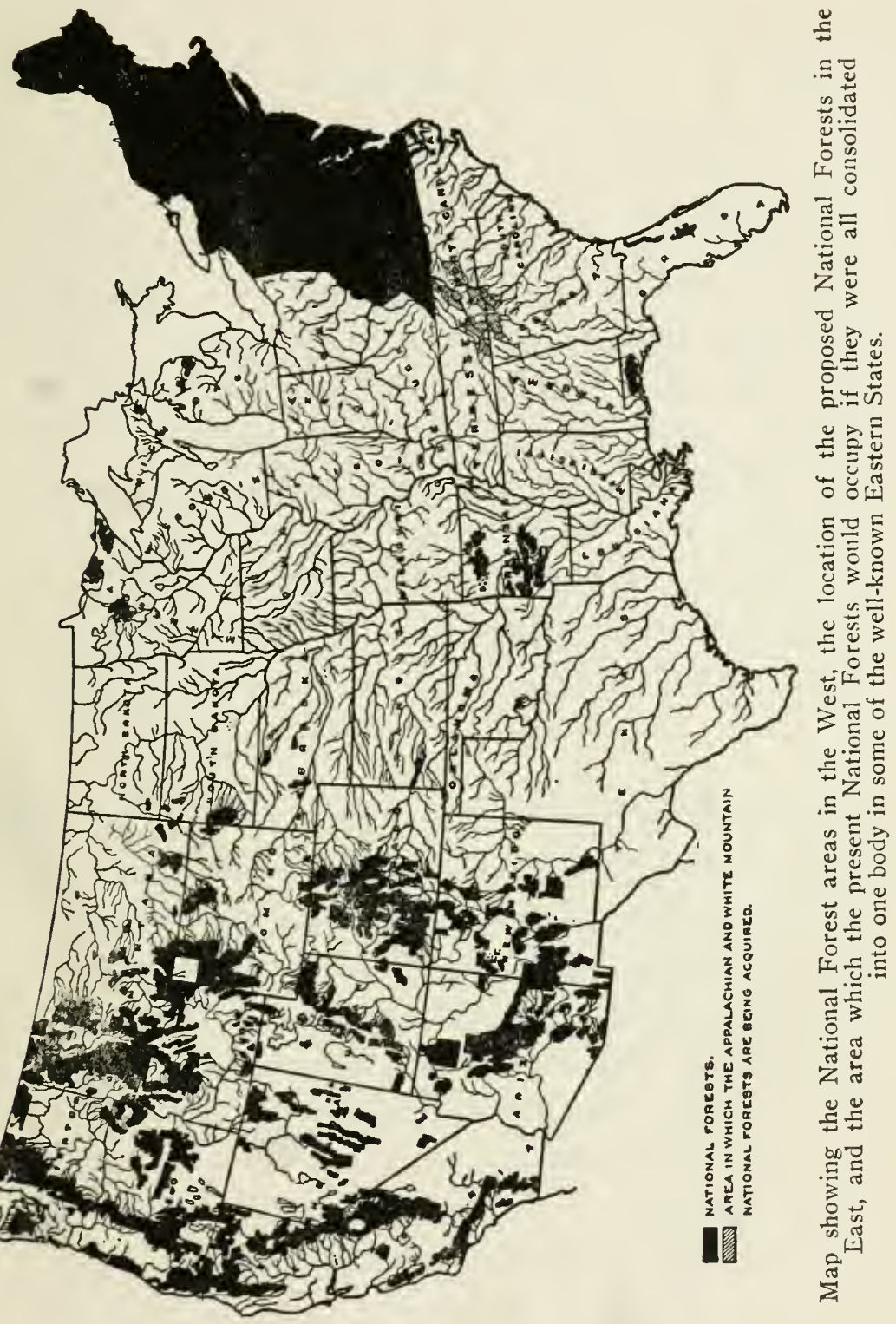



growing seasons too short for the production of crops such as wheat, corn, oats, potatoes, etc. Therefore, practically all of this land is what the forester calls "absolute forest land," that is, it is better adapted for growing timber crops than any other. Another important fact about the National Forests is that they are located, for the most part, on steep mountain slopes and at the headwaters of mountain streams. This makes them of vital importance in regulating the stream flow of our western rivers. In fact it is no exaggeration to say that all our large western rivers have their origin on National Forest land.

\section{WHY THE NATIONAL FORESTS WERE CREATED}

Aside from the great economic reasons why a nation should possess National Forests, there are local reasons which pertain to the welfare of the home builder and home industries which are often of paramount importance. The timber, the water, the pasture, the minerals, and all other resources on the government lands in the West are for the use of all the people. And only by a well-regulated policy of sale or rental can these resources be dis- 
posed so as to give all individuals an equal opportunity to enjoy them. These vast resources have been estimated to have a value of over $\$ 2,000,000,-$ 000. But their value to the local communities can hardly be overestimated. The welfare of every community is dependent upon a cheap and plentiful supply of timber. If lumber, fence posts, mine props, telephone poles, firewood, etc., must be brought in from distant markets, the prices are usually very much higher. The regulation of the cut on each National Forest assures a never-failing supply of timber to the home builder and to home industries. Then also the permanence of the great live stock industry is dependent upon a conservative use of vast areas of government range. Local residents are protected from unfair competition. Lastly, the protection by the Forest Service of the forest cover in the western mountains assures a regular stream flow which is of vital importance for power, irrigation, and domestic purposes.

Perhaps the most comprehensive statement upon the purposes of the National Forests and the methods and general policy of administering them is to be found in a letter by the Secretary of Agriculture to the Forester, dated February 1, 1905, when 


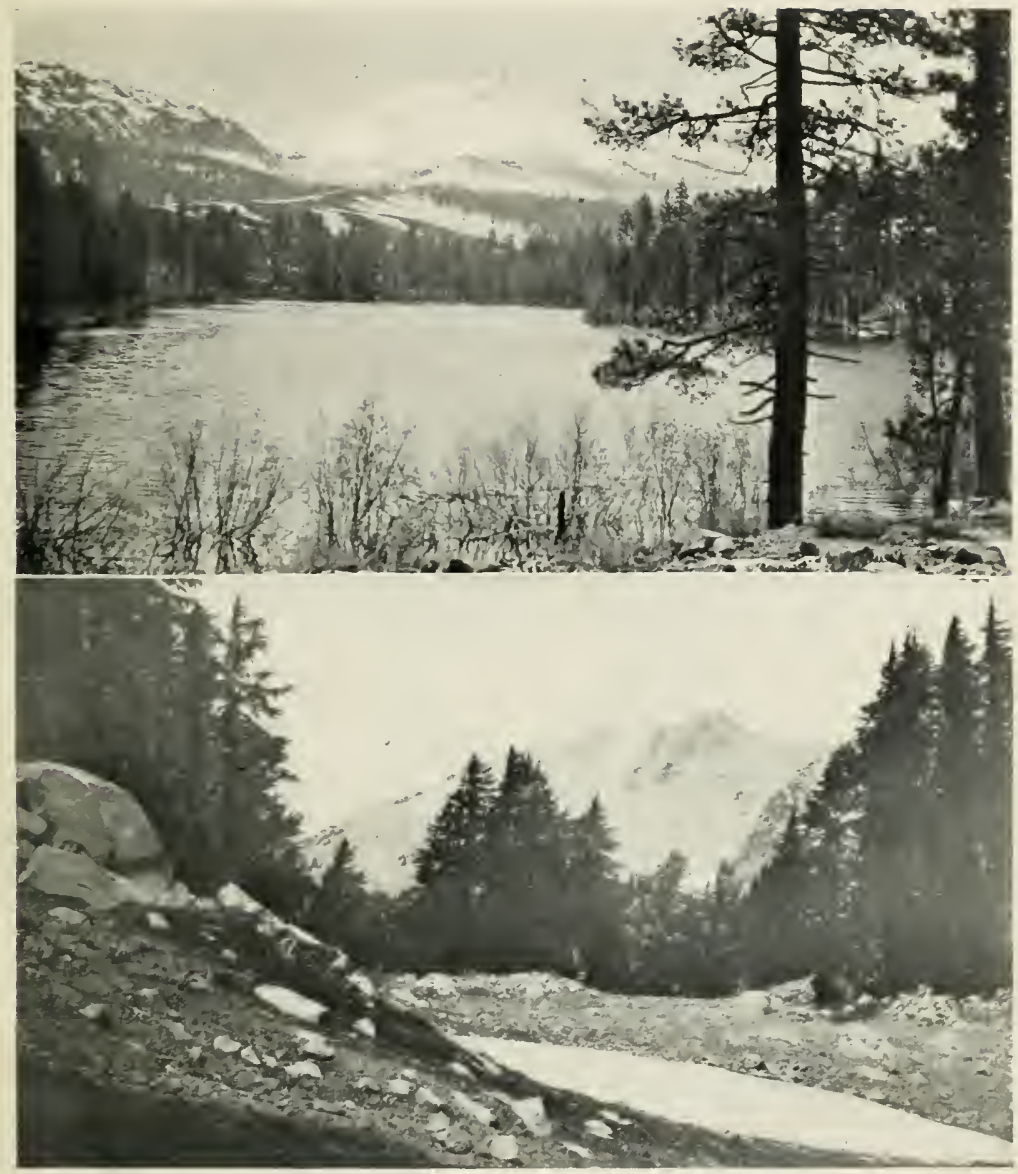

Figure 3. The climate of most of the National Forests is serere. This view was taken in the early summer and shows the high monntains still covered with snow. Most of the National Forest lands are therefore of small value for agriculture. Photo by Abbey.

Figure 4. On many high mountains on the National Forests snow banks persist througlout the summer. This riew was taken in the latter part of August. Lassen National Forest, California. Photo by the author. 

the Forests were turned over to the Department of Agriculture:

"In the administration of the forest reserves it must be clearly borne in mind that all land is to be devoted to its most productive use for the permanent good of the whole people, and not for the temporary benefit of individuals or companies. All the resources of the forest reserves are for use, and this use must be brought about in a thoroughly prompt and businesslike manner, under such restrictions only as will insure the permanence of these resources. The vital importance of forest reserves to the great industries of the Western States will be largely increased in the near future by the continued steady advance in settlement and development. The permanence of the resources of the reserves is therefore indispensable to continued prosperity, and the policy of this Department for their protection and use will invariably be guided by this fact, bearing in mind that the conservative use of these resources in no way conflicts with their permanent value.

"You will see to it that the water, wood, and forage of the reserves are conserved and wisely used for the benefit of the home builder first of all, upon whom depends the best permanent use of lands and resources alike. The continued prosperity of the agricultural, lumbering, mining, and livestock interests is directly dependent upon a permanent and accessible supply of water, wood, and forage, as well as upon the present and future use of these resources under businesslike regulations, enforced with promptness, effectiveness, and common sense. In the management of each reserve local questions will be decided upon local grounds; the dominant industry will be considered first, but with as little restriction to minor industries as may be possible; sudden changes in in- 
dustrial conditions will be avoided by gradual adjustment after due notice, and where conflicting interests must be reconciled the question will always be decided from the standpoint of the greatest good of the greatest number in the long run."

HOW THE NATIONAL FOREST POLICY HAS BENEFITED THE PEOPLE

This general policy, which was laid down by the Secretary of Agriculture, has been followed out, with the result that a great many benefits have been derived by the nation as a whole, by the individual States in which the National Forests are located, and, lastly, by the local communities and users of the Forests.

\section{The Remaining Timber Resources Were Saved.} First of all the timber, the forage, and the waterpower on the public domain has been reserved for the whole people and not for a privileged few. Before the Forest Reserve policy went into effect, the most valuable timber was being withdrawn from government ownership by the misuse of the public land laws, whose purpose and intent were fraudulently evaded. Many claims were initiated apparently for the purpose of establishing a homestead but in reality for the purposes of securing the tim- 
ber on the land and later to dispose of it to some large timber holder. Every citizen is allowed to exercise his homestead right. Big timber operators would secure the services of many dummy locators, pay the expenses of locating, improving, and perfecting the patent, and then buy the claim from these dummies for small sums. A large timber holder in California secured his hundreds of thousands of acres of timber land in this way. By instructing these men where to locate their claims he was able to secure more or less solid blocks of timber made up originally of 160 acre patches. These patches, which originally were bought by the lumber barons for from $\$ 500$ to $\$ 800$ a claim, now have a value of from $\$ 8,000$ to as high as $\$ 20,000$. The people of the United States have lost the difference.

It is difficult to say where or how this wholesale misuse of the public land laws would have ended if it had not been for the inauguration of the $\mathrm{Na}$ tional Forest policy. Since the Government has taken full charge of its forest domain, this misuse has stopped. In fact many of the fraudulent claims located years ago are being investigated, and if they are found to have been initiated with intent to defraud the Government, the land and the timber 
is returned to the National Forest in which it is located. To-day the National Forests contain about one fifth of the standing timber in the United States, an amount which will undoubtedly have a great effect upon the supply of timber available for future generations, especially since under present lumbering methods the privately owned timber lands are being practically destroyed, while the $\mathrm{Na}$ tional Forests are actually being improved by scientific management. Four fifths of the standing timber is privately owned, and this is usually of much higher quality than the publicly owned timber.

The Use of Frorage and Water Resources Was Regulated. The forage and water resources of the public domain have been subject to similar abuse. Before the National Forest policy was put into effect the large ranges of the West were used indiscriminately by all. The range was subject to considerable abuse because it was used very early in the spring before the forage was mature, or too late in the fall, which prevented the forage from ripening its seed and reproducing for the next season. Not the small, local stockmen, however, but the large sheep and cattle companies, many con- 


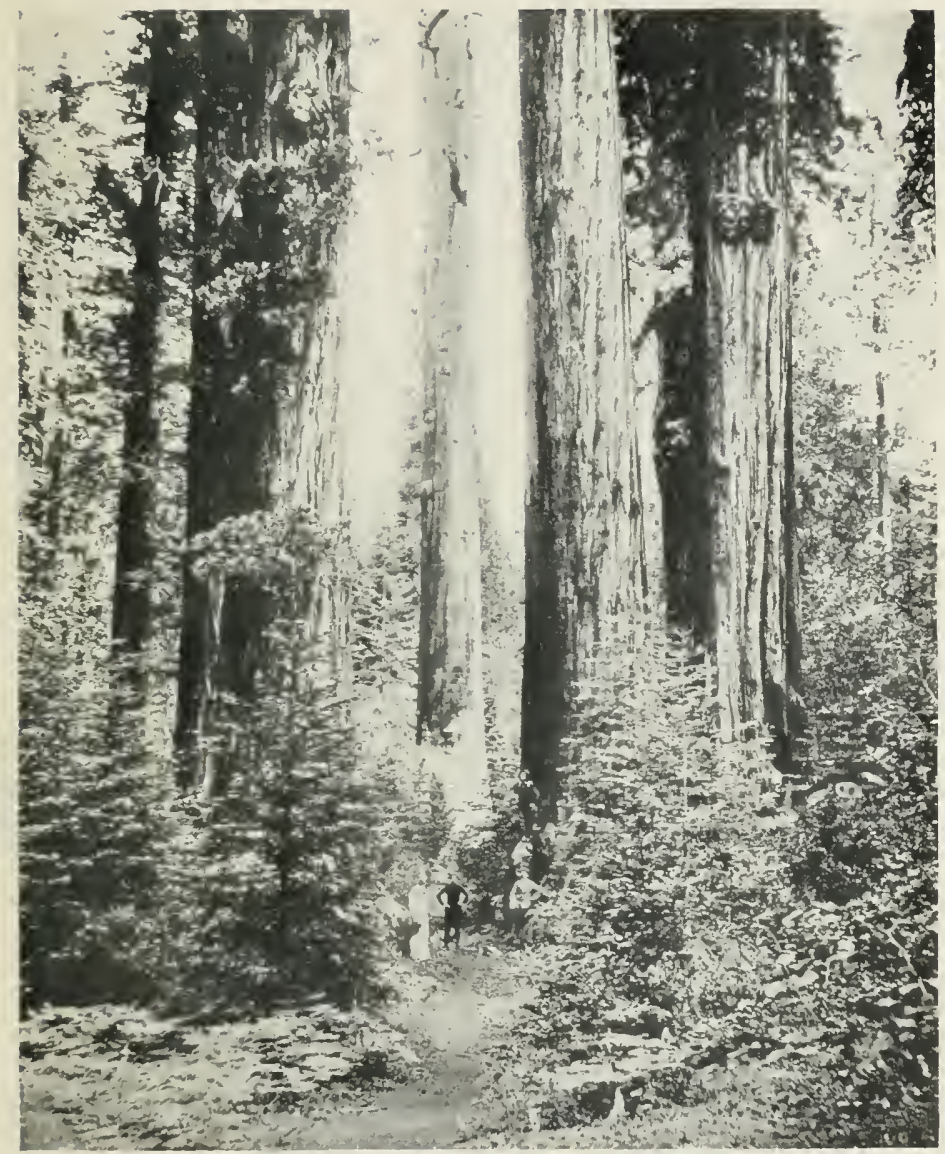

Figure 5. The Big Trees. "Mother of the Forest" in the background. North Calaveras Grove, California 

trolled by foreign capital, benefited by this condition of affairs. These "big men," as they were called, illegally fenced and monopolized large areas, varying in size from townships to entire counties. What chance would a local rancher with fifty or sixty cattle have against a million-dollar outfit with perhaps 40,000 to 50,000 cattle? He was merely swallowed up, so to speak, and had no chance whatever to get his small share. "Might made right" in those days, and it is said that if a man held any title or equity on the range it was a "shotgun" title. Also, the sheep and cattle men had innumerable disputes about the use of the range which in many cases resulted in bloodshed. If a sheep man arrived first on the range in the spring with his large bands of sheep, he simply took the feed. The Government owned the land and the forage but it had no organization in the field to regulate the use of it. It was indeed a chaotic condition of affairs and ended only after the inauguration of the present policy of leasing the lands under the permit system. These permits are issued and charged for upon a per capita basis.

The conservative and regulated use of the grazing lands under Forest Service supervision has re- 
sulted in better growth and better weights on stock and more actual profit. 'There are ample data that show that the National Forests produce some of the best lambs that are put upon the market. Data secured from the Modoc National Forest, California, in 1910, show that lambs brought 50 cents per head more and weighed an average of 10 pounds more than lambs produced outside the Forest. Weights taken of 10,000 head showed an average of 72 pounds for National Forest lambs, while outside the Forest average weights on 3,000 lambs showed only 62 pounds. The regulation of the length of the grazing season, the introduction of better methods of handling sheep, and the prevention of over-grazing are some of the Forest Service methods that produce better lambs.

Then also under the old system the valuable water-power sites were being rapidly eliminated from government ownership by large corporations who secured valuable property for a song. The National Forests, however, still contain about onethird of the potential water-power resources of the United States and over 40 per cent. of the estimated power resources of the Western States. And this vast wealth will not pass from the owner- 
ship of the United States but will be leased under long-term leases from which the Government will receive yearly a fair rental.

The Forests Were Protected from Fire and Trespass. But not only have these large timber, forage, and power resources been put under administration for the use of the people. The protection of the National Forests, which goes hand in hand with their administration, means a great deal to the local communities, the States, and the nation as a whole. Until about twenty years ago the forests upon our public lands-the timber of the Rocky Mountains from Montana to New Mexico and of the Pacific Coast ranges from northern Washington to southern California-seemed destined to be destroyed by fire and reckless, illegal cutting. Nothing whatever was being done to protect them from fire or trespass. They were simply left to burn. When the people living near the public domain wanted any house logs, fence posts, or firewood, they went into the public domain and took them. The best trees were usually taken first. In California, especially, there was a common practice of cutting down the finest sugar pine trees and sutting and splitting them into shakes to make a 
roof covering. Then, too, much government timber was stolen by lumber companies operating in the vicinity of valuable government timber. After the land had been stripped of everything of value a fire was started in the slashing, which among other things burned the stumps and thus practically obliterated all evidence of trespass. Had this destruction continued there would to-day have been little timber left in the West, and the development of the country which demands timber all the time, and not only at certain intervals, would have been retarded, if not stopped altogether.

How terrible the forest fires were in this western country is well illustrated by what an old California settler once told me, and what I have heard repeatedly in many Western States. He said: "In the years before the Forest Service took over the care and protection of the forests around here, the mountains within view of my ranch were not visible for many months at a time, being almost continually enveloped in smoke from the big forest fires that were raging in the forests all summer without ever being under control. They started in the spring as soon as it became dry and were not suppressed until the late fall rains and snows put them 


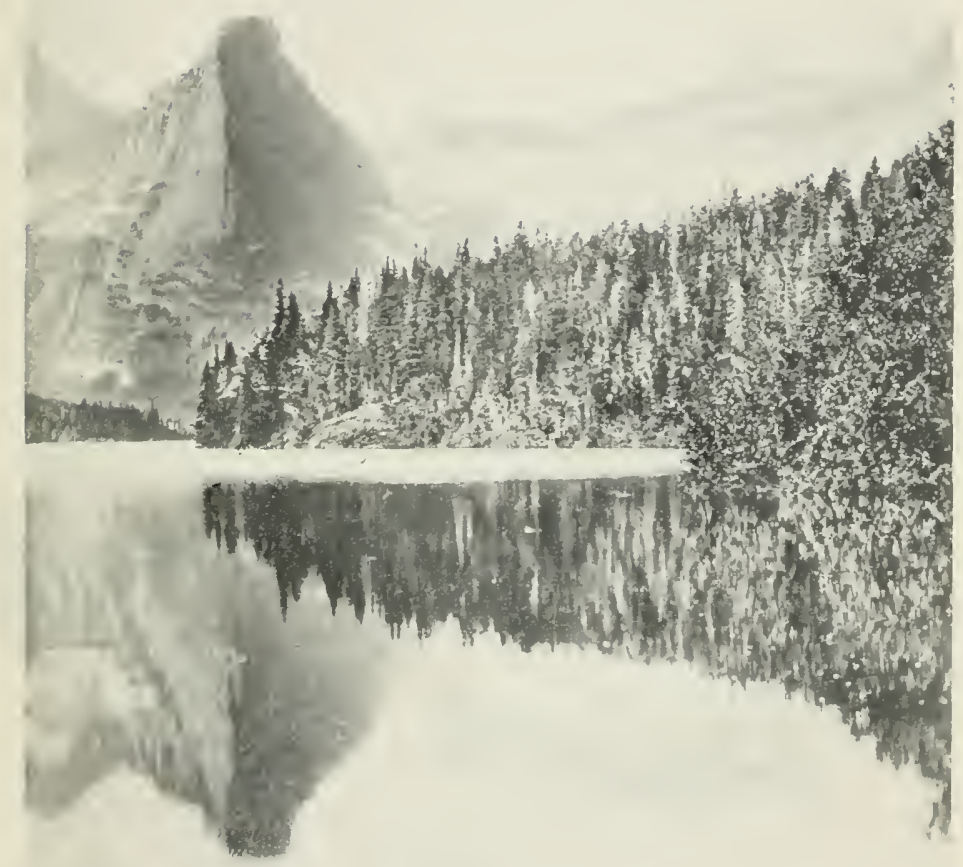

Figure 6. I scene on one of the famoms National Parks. Cpper Lake, Glacier National Park, Northern Rockies, Montana 

out." But he added with great enthusiasm, "Since the Service has taken charge the sky around here is as clear as crystal all summer. I never see any forest fires, not even smoke, because the Rangers seem to get to them before they get to be of any size." Such testimony as this speaks volumes for the efficiency of the present system of protecting the Forests from fire.

The $\boldsymbol{W}$ atershed Cover $\boldsymbol{W}$ as Preserved. The destruction of the forest cover on the watersheds feeding thousands of streams which rise in the western mountains would have had its bad effect on stream flow-low water during the long dry periods, and destructive floods after heavy rains. This condition of affairs would have meant disaster to the systems of irrigation by which most of the western farmers raise their crops. It would also have seriously impeded and in many cases prevented electric power development, to say nothing of affecting the domestic water of many of our large western cities whose drinking water comes from the streams rising in the National Forests. The protection of these valuable watersheds by the Forest Service from fire and destructive lumbering is of such vital importance to the wel- 
fare of the nation that it has been made one of the main reasons for establishing National Forests.

Civilization Brought to the Mountains. What the National Forest movement has done for settling and building up the Western States can hardly be overestimated. It has brought civilization into the wilderness. Roads, trails, telephone lines, and other modern conveniences have been brought to remote corners of the mountains. It has encouraged the settlement of the country by calling attention to the agricultural lands within the National Forests. More important than that, it has assured the West permanent towns, permanent civilization, and not a temporary, careless, shiftless civilization which vanishes with the exploitation of resources, as it did under the old régime.

The improvements on the National Forests have benefited not only the Forest officers for the administration of the Forests. They have helped immensely the local population. The pleasure resorts as well as the business of the Forests have been made more accessible. New trails have opened up new and hitherto inaccessible country, where fishing, hunting, and trapping are ideal. All the old and new roads and trails have been well marked with 
sign boards giving the tourist detailed information about distances between the various points of interest. Roads have opened up new regions to automobiles and to the horse and wagon. In 1916 it was estimated that more than $2,000,000$ people visited the National Forests for recreation and pleasure. They came in automobiles, in horse and wagon, on horseback, on mules, on burros, and in all sorts of made-to-order contrivances, and the writer has even seen those that could not afford anything better, pack their camp outfits in a wheelbarrow and push it before them in their effor't to leave the hot, dusty valleys below, and go to the refreshing and invigorating Forests of Uncle Sam. In addition to the large numbers of tourists that visit the National Forests every year, over $\mathbf{1 0 0 , 0 0 0}$ persons or companies use the National Forests. Of these a little more than half are paid users, who are charged a fair fee for timber, grazing, or other privileges and a little less than half enjoy free use privileges.

Agricultural Lands Opened to Settlement. The settlement of the agricultural lands in the National Forests is a matter that has received special attention at the hands of the Forest Service in late years. Land more valuable for agriculture than for timber 
growing was excluded from the National Forests before the boundaries were drawn, so far as this was possible. Small tracts of agricultural land within the Forests which could not be excluded are opened to settlement under the Forest Homestead Act of June 11, 1906. The amount of land, however, that is more valuable for agriculture than for timber is trifling, because the greater part of the valuable land was already settled before the Forests were created. The few small patches that are left inside of the National Forest boundaries are rapidly being classified and opened to entry for homesteads. Much of the land apparently adapted for agricultural purposes has a severe climate because it lies at high altitudes and it is often remote from roads, schools, villages, and markets. Therefore the chance offered the prospective settler in the immediate vicinity of the Forests is far better than in the Forests themselves. The Forest Service is doing everything it can to encourage homesteaders on the National Forests; it wants them because they help to report fires, help to fight fires, and in many other ways assist the Forest officers.

Permanent and Not Temporary Civilization Resulted. Only those people who have been brought 
up near a large lumbering center can appreciate what it means when a town vanishes; when all that is left of a thriving town of 5,000 or more souls is empty streets, empty houses, and heaps of tin cans. In the days of the Golden Age of lumbering in Michigan many towns flourished in the midst of the forests. 'These towns had thrifty, busy people, with schools, churches, banks, and other conveniences. These people were engaged in exploiting the forests. The beautiful white pine forests were converted into boards at the rate of thousands of feet every day. When these magnificent forests were laid low, the lumbermen left to seek virgin timber elsewhere. They left behind them empty towns and barren lands; only a few charred stumps remained to show where the forests once stood. But this is not an incident peculiar to the Golden Age of lumbering in Michigan. Even to-day this very thing is happening. The town of Crossfork, Potter County, Pennsylvania, had a population of over 2,500 souls in 1909 . When the near-by timber was exhausted, practically the whole town was abandoned. In 1913 it had a population of 50 .

In direct contrast to this short-sighted policy of the State of Michigan (and many others also) is 
the National Forest policy, which provides for a future supply of forest products as well as a present supply; which provides for work and homes and schools and churches for future generations as well as for the present; which provides for a permanent industry and not one that vanishes with the exploitation of the resources of a region as snow vanishes under the warm rays of a spring day. Lumbering even to-day is merely the removal of every vestige of timber that has any sale value. But forestry, which is practiced on the National Forests, removes only the mature trees, leaving the young growth to be cut at some future time. Lumbering has been and is to-day forest destruction; forestry is forest conservation under a system of wise use. Lumbering is followed usually by fire, and often by an entire impoverishment of the region in which it is carried on because it destroys both the mature tree and the young growth; under a system of forestry, cutting is followed by young, green forests which are protected from fire for the benefit of future generations. Such a system leaves the region and the industry in a permanent, good condition. The county under the old system receives no more taxes after its wealth is gone; but each county 

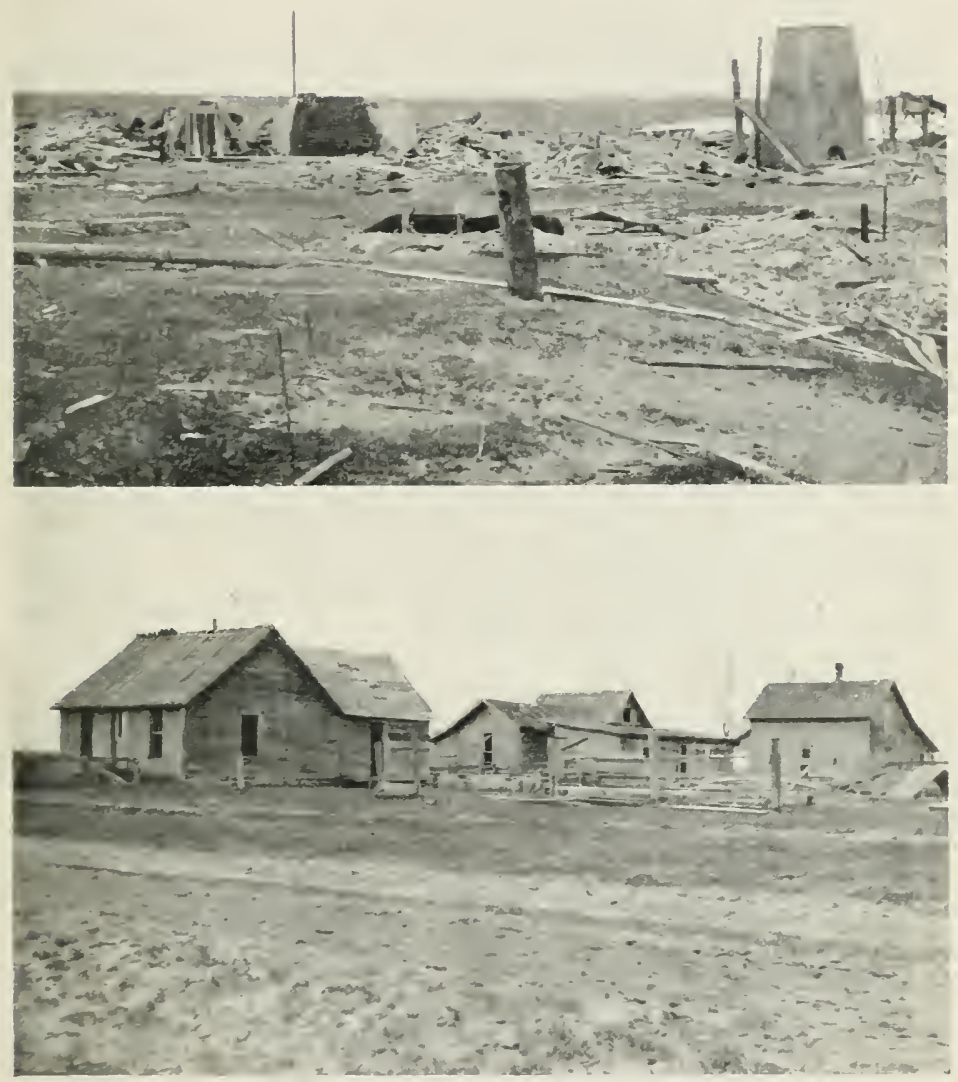

Figure $\tau$. 'The remains of the old boiler house. 'The town once had a sawmill, planing mill, lath mill, besides modern conveniences. All these are now gone after the forests have been cut. Lemiston, Montmorency Countr, Michigan.

Figure \&. Deserted houses, ahandoned after the sawmill left. These are the remains of what was once a prosperous town. Lemiston, Montmorency Countr. Michigan. 

will receive taxes or money in lieu of taxes every year as long as the National Forests shall endure.

Financial Returns. All the benefits of which I have spoken are without doubt great assets to the local community, to the State, and to the nation as a whole. They are great contributions to the welfare of our country even though they cannot be measured in dollars and cents. This brings us then to the financial aspect of the National Forest movement. Even though the fundamental purpose of the National Forests was in no sense a financial one, it is interesting to look into the finances of this great forestry enterprise.

The total regular appropriation for salaries, general expenses, and improvements for the fiscal year 1918 is $\$ 5,712,275$. For 1917 it was slightly less than this: $\$ 5,574,735$. The receipts from the sale or rental of National Forest resources in the fiscal year 1917 reached $\$ 3,457,028.41$. From these figures it will be seen that the expenditures exceed the receipts by between $\$ 2,000,000$ and $\$ 3,000,000$ a year, depending partly on the severity of the fire season and partly on the activity of the general lumber market. When we consider that this is really a newly established business scarcely twenty 
years old; that large expenditures have been made and must necessarily be made every year for equipment and improvements before the resources could even be used; and that an efficient organization had to be built up to handle the business, we must confess that the receipts are really a wonderful showing.

When the Forest Reserves were taken over by the Government it could not be expected that they would yield a revenue at the very outset, nor could it be expected that even in the long space of twentyfive years they could be made self-supporting. The reasons for this are many. They are located for the most part in rugged, inaccessible mountains. In the case of almost every Forest a great deal of money had to be expended for roads, trails, telephone lines, fences, bridges, ranger stations and other cabins, lookout structures, fire lines, and many other improvements before the resources could even be used. Many of the resources were practically locked up; there were no roads by which to get them out of the wilderness. During the fiscal year 1916 alone there were built 227 miles of roads, 1,975 miles of trails, 2,124 miles of telephone lines, 89 miles of fire lines, 81 lookout structures, 40 
bridges, 222 miles of fences, 545 dwellings, barns, and other structures, and many other improvements. Up to date there have been constructed over 3,000 miles of roads, over 25,000 miles of trails, about 23,000 miles of telephone lines, 860 miles of firebreaks, about 360 forest fire lookout cabins and towers, and many other improvements. Their total value is estimated at $\$ 7,000,000$. And these vast improvements are but a small percentage of the improvements which will be necessary to be able to put these Forests to their highest use.

Not only must enormous sums be spent for improvements. The huge sums which are spent for the protection of the great resources bring no tangible return in dollars and cents; yet the fire protection system prevents the destruction of millions of dollars' worth of timber every year. 'Then again, when government timber lands are cut over, only the mature trees are taken; the smaller trees, although they have a commercial value, are left on the ground to mature because they will have a still greater value in from forty to fifty years. This is merely foregoing a small present revenue for a larger future one. Also many National Forests have on them large areas of steep mountain slopes 
where not a stick of timber is allowed to be cut. These areas are maintained intact for watershed protection. In fact many of the Forests of southern California are maintained solely for this purpose. These Forests are covered almost entirely by a low bush-like growth called "chaparral," which has no value either as timber or as browse, but which has great value to preserve an equable stream flow for domestic use, irrigation, and water power.

But there are still other reasons why the cash receipts from the National Forests are not as large as they might be. In addition to the cash receipts the equivalent of a large revenue is foregone every year through the various forms of free use and the sale of timber to settlers at cost instead of at its actual cash value. During the fiscal year 1917 approximately $\$ 150,000$ worth of timber was given to settlers free of cost. About 40,000 people were served under this policy. Also much timber is sold at cost to settlers for domestic use. In this way over 4,400 persons received many millions of feet of timber whose cost value was about $\$ 20,000$, but whose sale value was much greater. The privilege of grazing a small number of stock free of charge is granted to settlers living on or near the Forests. 
The stock thus grazed amounts to about $\mathbf{1 2 5 , 0 0 0}$ animals every year. The Forests are also put to many special uses for which no charge is made although their administration involves some expense. Strict accounting should credit the fair value of such uses to the receipts from the National Forests, for it is in effect income which instead of being put into the treasury is made available for the benefit of the people.

From what has been said it will be seen that a large part of the benefits derived from the systematic administration of the National Forests cannot be measured in dollars and cents. These benefits are in effect privileges extended to the people who in return assist in the protection of the Forests from fire and thus more than repay the Government for what they receive. Even under the rather unfavorable revenue producing conditions mentioned above, it is interesting to note that in 1917 the receipts of thirty-two National Forests exceeded their total expenditures. On fifteen others the receipts exceeded the cost of protection and administration. In other words, one-third of the National Forests are practically self-supporting.

The Ner Eastern National Forests. The great 
success with which the National Forest policy was launched in the Western States was largely responsible for the inauguration of a similar policy in the Appalachian and White Mountains. The main purpose for which these forests are to be acquired is to preserve a steady stream flow for waterpower navigation and domestic use, and to lessen the damage caused by floods and erosion. These forests are of vital influence in controlling the flow of the Melrimac, Connecticut, Androscoggin, Potomac, James, Santee, Savannah, Tennessee, and Monongahela rivers. Some years ago the Merrimac drove mills worth over $\$ 100,000,000$, which employed over 80,000 people. Upon these, it is said, 350,000 were dependent for support. In the Carolinas and Georgia alone the cotton mills operated by water-power turn out an annual product valued at almost $\$ 100,000,000$. In these mills 60,000 people are employed, upon whom 250,000 are dependent for support. These mills utilize 106,000 horse-power. The forests which control these waters are therefore of great pecuniary value.

The Act of March 1, 1911, commonly known as the Weeks Law, made the acquisition of forest lands in the Appalachian and White Mountains 
possible. Up to June 30,1917 , over $1,500,000$ acres have been approved for purchase by the $\mathrm{Na}$ tional Forest Reservation Commission. The Forest Service has been designated as the bureau to examine and value such lands as may be offered for purchase. The original appropriation was $\$ 2,000,000$ per year for five and one-half years, beginning the last half of the fiscal year 1911. The Agricultural Appropriation Bill for the fiscal year 1913 made the appropriation for 1912 and subsequent years available until expended. A further appropriation of $\$ 3,000,000$ was provided later for the same purpose, to be expended during the fiscal years 1917 and 1918. Under Section 2 of the same law coöperative fire protection with the States was provided for. This section of the law provided that the Forest Service should maintain a coöperative system of forest fire protection with those States which have a law providing for a system of fire protection for state and private forest lands upon the watersheds of navigable streams. In no case was the amount to be expended by the Forest Service to exceed the amount appropriated by the State for the same purpose in any given fiscal year. The original appropriation was $\$ 200,000$ and sub- 
sequent appropriations have been for $\$ 100,000$ annually. Twenty-one States are coöperating with the Forest Service in this way.

By the passage of the Weeks Bill, Congress has voiced the sentiment that the forest fire problem, even on private land, is not only no longer a private problem, is not even exclusively a state problem, but a joint problem and duty to be borne by the State and nation. Forest fires are now rightfully looked upon as a public enemy rather than a private menace. This is a big step in the right direction, and it is hoped that this same principle will be applied in the not too distant future to all other matters dealing with private timber lands. If the protection of these private timber lands is a public and not a private problem, then certainly their management for continuity is a public problem. A timber owner should not be allowed to cut his timber without the consent of the Government, and the Government should see to it that he leaves the young growth as a basis for a future crop or provides a new growth of timber by planting young trees. 


\section{TABLE OF CON'TENTS}

PrEFACE . . . . . . . . . . . . . v vii

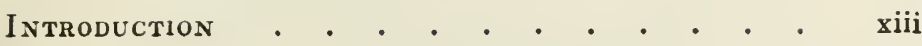

Forestry as a National Problem . . . . . xiii

Our consumption of wood . . . . . . xii

The lumber industry . . . . . . . xiv

Our future lumber supply . . . . . . $\quad$ xv

Forests and stream flow . . . . . . e xvi

Forests and erosion . . . . . . . . . $\quad$ xvii

Forestry a public enterprise . . . . . xviii

The Extent and Character of Our National Forests . . . . . . . . xix

How the Government obtained the National Forest lands . . . . . . . . . xix

The romance of the National Forest region . $\quad x x$

Famous scenic wonders near the Forests . . xxii

The size and extent of the National Forests . xxiv

The topograplyy and climate of the National

Forest region . . . . . . . . xxvi

Why the National Forests were Created . . xxvii

How the National Forest Policy has Benefited the People . . . . . . . . . $\mathrm{xxx}$

The remaining timber resources were saved . $x x x$

The use of forage and water resources was regulated

The Forests were protected from fire and trespass . . . . . . . . . . $\mathrm{x} \times x \mathrm{v}$

The watershed cover was preserved . . . xxxvii

Civilization brought to the mountains . . xxxviii

Agricultural lands opened to settlement . . xxxix

Permanent and not temporary civilization resulted

Financial returns . . . . . . . . xliii

The new eastern National Forests . . . xlvii 
I The Creation and Organization of the National Forests . . . . . . . . . . . 1

Economic Conditions Which Led to Forest Conservation . . . . . . . . . . 1 Prodigality leads finally to conservation . . I The march of forest destruction . . . . . 2

Our lumber and water supply imperiled . . . 5 The First Steps in Federal Forest Conservation . 6

The upbuilding of the West . . . . . . 6

The Lake States first to act . . . . . . 7

The first federal steps . . . . . . . 8

The Act of August 16,1876 . . . . . . . $\quad$. 9

Further work under the Act . . . . . . 11

The First Forest Reserves Established March 30, 1891 . • . • . . • . . . . . 12

The situation before 1891 . $. \quad . \quad . \quad . \quad .12$

The need of the forest policy . . . . . . 13

The Act of March 3,1891 . . . . . . 11

An Anomalous Condition-Forest Reserves Without Forest Administration . . . . . . 14

The Need of Administration on the Reserves . 14

More Reserves created . . . . . . . 16

The Administration of the Reserves Under the

General Land Office . . . . . . 16

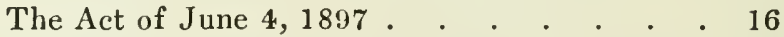

The Division of Forestry in 1898 . . . . 18

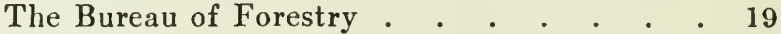

The Consolidation of the Forestry Work in the Department of Agriculture in 1905 . . $\quad 19$

The Act of February 1, 1905 . . . . . 19

Early forestry education and literature . . . 20

Changes in the Forest Service personnel . . 21

More National Forests created . . . . . 21

The growth of the Forest Service . . . . 22

Recent modifications in the organization . . 23

The Present Organization of the Forest Service . 24

The administrative districts . . . . . . 24

The Washington office . . . . . . . 26

The district offices . . . . . . . . 28 
II The Administration of the National Forests a 30 Personnel • . • • • . . . . . . 31

Duties of forest officers . . . . . . . 31

The Forest Supervisor . . . . . . . 32

The Forest Assistant . . . . . . . 34

The Forest Ranger . . . . . . . . 35

The Forest Clerk . . . . . . . . . 38

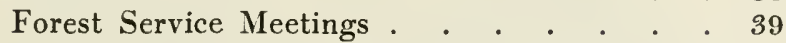

How the Forest Service Appropriation is Allotted to the National Forests . . . . . . 40

Forest Service expenses . . . . . . . 40

The agricultural appropriation bill . . . . 42

The ranger's protection and improvement plans 42

The Supervisor's plans . . . . . . . 43

Approval of plans by the District Forester . . 44

The district fiscal agent . . . . . . 45

Tax money paid to the states . . . . . 46

The Equipment and Supplies for the National

Forests . . . . . . . . . . 47

The property auditor and property clerk . . 47

Blănk forms . . . . . . . . . . 48

Supplies . . . . . . . . . . . . 48

National Forest Improvements . . . . . . 49

The need of improvements . . . . . . 49

Transportation facilities . . . . . . . 50

Communication facilities . . . . . . 53

Grazing improvements . . . . . . 56

Protection improvements . . . . . . . 57

Appropriations for improvement work . . . 58

The Classification and Consolidation of National Forest Lands . . . . . . . . . 61

Land classification . . . . . . . . 61

The consolidation of National Forest lands . 63

How Young Forests are Planted to Replace Those

Destroyed by Fire. . . . . . . . 64

Reforestation and the timber supply . . . 64

Reforestation and water supply . . . . 65

Government reforestation policy . . . . . 67

Methods of reforestation . . . . . . . 70 
Direct seeding work on the National Forests . 72

Planting on the National Forests . . . 78

The Organization and Scopc of Forest Experiments and Investigations . . . . . 83

The need of scientific experiments . . . 83

The science of growing timber . . . . . 84

Dendrological studies . . . . . . . 86

Seed studies . . . . . . . . . . . $\quad$. 87

Nursery studies . . . . . . . . . 88

Forestation experiments . . . . . . . $\quad$. 89

Studies of forest influences . . . . . . . $\quad$. $\quad 89$

Meteorological observations . . . . . . 91

Forest management studies . . . . . . 92

Forest protection studies . . . . . . . . 94

Protection from grazing damage . . . . 95

Protection from insects and diseases . . . 96

Tree studies . . . . . . . . . . . $\quad .97$

Grazing investigations . . . . . . . 98

Investigations dealing with poisonous plants and predatory animals . . . . . . . . 102

National Forest utilization experiments . . . 104

Forest Products Laboratory experiments . . 108

Industrial investigations . . . . . . . 116

III The Protection of the National Forests . . 120

Protection from Fire . . . . . . . . 120

Forest Fire danger on the National Forests . 120

Importance of fire protection . . . . 121

Causes of forest fires on the National Forests . 124

Behavior of forest fires . . . . . . 126

Losses by forest fires on the National Forests 126

The forest fire problem stated . . . . 128

Fire prevention . . . . . . . . . 129

Fire suppression . . . . . . . . . 133

How forest fire funds are distributed . . 134

Forest fire history . . . . . . . . 136

Relation of forest fires to the weather . . 137

Improvements and equipment for protection . 138

Forest fire maps and charts . . . . . . 139

Forest fire organization . . . . . . . 140 
How fires are located.

142

The fire fighting organization . . . . . 144

Forest fire coöperation . . . . . . . 146

Fighting forest fires . . . . . . . . 147

Protection Against Trespass, Forest Insects,

Erosion, and Other Agencies . . . . 150

Trespass . . . . . . . . . . . 150

Forest insects . . . . . . . . . . 154

Tree diseases . . . . . . . . . . . 159

Water supply . . . . . . . . . . 162

Public health . . . . . . . . . . 167

Violation of game laws . . . . . . 168

IV The Sale and Rental of National Forest ReSOURCES • . . . • . . . . . . 170

The Sale and Disposal of National Forest Timber 170

Government Timber Sale Policy . . . . . 171

Annual yield and cut . . . . . . . 172

Timber reconnoissance . . . . . . . 174

Logging the timber . . . . . . . . 176

The first step in purchasing government timber 180

Procedure in an advertised sale . . . . . 180

Timber sale contract clauses . . . . . . 182

Special contract clauses . . . . . . . 184

When the operation may begin . . . . . 186

Marking the timber for cutting . . . . . 186

Scaling, measuring, and stamping . . . 188

Disposal of slash . . . . . . . . . 190

Payment for timber . . . . . . . . 192

Stumpage rates . . . . . . . . . 193

Cutting period . . . . . . . . . 194

Readjustment of Stumpage rates . . . . 194

Refunds . . . . . . . . . . . 194

The Disposal of timber to Homestead Settlers and

Under Free Use . . . . . . . . 195

Sales to homestead settlers and farmers . . 195

Free Use . . . . . . . . . . . 195

Timber Settlement and Administrative Use . . 198

The Rental of National Forest Range Lands . . 200 
PAGE

Importance of the live-stock industry . . 200

Permits issued in 1917 . . . . . . . 201

Kinds of range, grazing seasons, and methods handling stock. . . . . . . . . 202

Grazing districts and grazing units . . . 205

Who are entitled to grazing privileges . . . 207

Grazing permits . . . . . . . . . 211

Grazing fees . . . . . . . . . . 214

Stock associations . . . . . . . . . . 215

Protective and maximum limits . . . . 2 216

Prohibition of grazing . . . . . . . 218

Protection of grazing interests . . . . . 219

Special Uses . . . . . . . . . . . 220

Claims and Settlement . . . . . . . 223

The National Forest Homestead Act . . . 224

The mining laws . . . . . . . . . 229

Coal-land laws . . . . . . . . 230

Administrative Use of National Forest Lands . 230

Water Power, Telephone, Telegraph, and Power

Transmission Lines . . . . . . . 230

APPENDIX . . . . . . . . . . . . . 233 


\section{ILLUSTRATIONS}

Figure 1. An observation point for finding forest fires. Vigilance is the watchword on the National Forests. During 1916 forest officers extinguished 5,655 forest fires. Photo by the author . . . . . . . . . Frontispiece

Figure 2. A typical National Forest landscape in the high mountains. Potosi Peak, 13,763 feet, from Yankee Boy Basin, Uncompahgre $\mathrm{Na}^{-}$ tional Forest, Ouray County, Colorado . . xviii

Figure 3. The climate of most of the National Forests is severe. This view was taken in the early summer and shows the high mountains still covered with snow. Most of the National Forest lands are therefore of small value for agriculture. Photo by Abbey . . . . xxviii

Figure 4. On many high mountains on the National Forests snow banks persist throughout the summer. This view was taken in the latter part of August. Lassen National Forest, California. Photo by the author . . . xxviii

Figure 5. The Big Trees. "Mother of the Forest" in the background. North Calaveras Grove, California . . . . . . . . . . xxxii

Figure 6. A scene on one of the famous National Parks. Upper Lake, Glacier National Park, Northern Rockies, Montana . . . . . xxxvi

Figure 7. The remains of the old boiler house. The town once had a sawmill, planing mill, lath mill, besides modern conveniences. All these 
are now gone after the forests have been cut. Lemiston, Montmorency County, Michigan . xlii

Figure 8. Deserted houses, abandoned after the sawmill left. These are the remains of what was once a prosperous town. Lemiston, Montmorency County, Michigan . . . . xli

Figure 9. Forest officers in front of the Forest Supervisor's summer headquarters. Note the many telephone wires that lead from the office. This is 50 miles from the railroad. Lassen National Forest, California . .

Figure 10. Scene in front of the Forest Supervisor's headquarters. Sheep leaving the National Forest summer range in the fall to go to winter range in the valley. Lassen National Forest, California . . . . . . .

Figure 11. Forest officers and lumberjacks burning the slash resulting from a timber sale. The snow on the ground makes the burning less dangerous. Washakie National Forest, Wyoming. Photo by the author . . . .

Figure 12. Forest officers at a winter timber-cruising camp repairing snow shoes. Besides cruising the timber, these men make a logging map of the government lands, to show how the timber can best be taken out. Lassen National Forest, California. Photo by the author

Figure 13. A forest fire lookout tower on Leek Springs Mountain, Eldorado National Forest, California

Figure 14. A typical Forest Ranger's headquarters. Idlewood Ranger Station, Arapaho National Forest, Colorado . . . . . . . 


\section{ILLUSTRATIONS}

Figure 15. A typical view of the National Forest country in Montana. Forest Service trail up Squaw Peak Patrol Station, Cabinet National Forest . . . . . . . . . .

Figure 16. Forest Rangers repairing a bridge over a mountain stream. Arapaho National Forest, Colorado . . . . . . . . .

Figure 17. A forest fire lookout station on the top of Lassen Peak, elevation 10,400 feet, Lassen National Forest, California. The cabin was first erected complete in a carpenter's shop in Red Bluff, about 50 miles away. It was then taken to pieces and packed to the foot of Lassen Peak. On the last two miles of its journey it was packed piece by piece on forest officers' backs and finally reassembled on the topmost pinnacle of the mountain. Photo by the author . . . . .

Figure 18. Forest officers and laborers building a wagon road through trap rock. Payette National Forest, Idaho . . . . . . . . .

Figure 19. Drying pine cones preparatory to extracting the seed. Near Plumas National Forest, California . . . . . . . . .

Figure 20. Extracting tree seed from the cones. The dried cones are shaken around until the secds drop out through the wire mesh which forms the sides of the machine

Figure 21. Preparing the ground with a spring-tooth harrow for the broadcast sowing of tree seeds. Battlement National Forest, Colorado. This view was taken at approximately 10,000 feet elevation. Photo by the author

Figure 22. A local settler delivering a load of Lodgepole pine cones at the seed extractory, for 
which he receives 45 cents per bushel. Forest officers receiving them, Arapaho National Forest, Colorado

Figure 23. In a forest nursery a trough is often used for sowing seeds in drills. The seed scattered along the sides of the trough rattles into position at the bottom and is more even than when distributed by the ordinary worker at the bottom of the trough. Pike National Forest, Colorado . . . . . . . .

Figure 24. Uncle Sam grows the little trees by the millions. These will soon cover some of the bare hillsides on the National Forests of the West . . . . . . . . .

Figure 25. One of the largest Forest Service nurseries where the young trees are given the utmost care before they are large and strong enough to endure the rigorous climate of the National Forests. McCloud Nursery, Shasta National Forest, California . . . . . .

Figure 26. A view of seed sowing with a corn planter. San Isabel National Forest, Colorado . .

Figure 27. Sowing seed along contour lines on the slopes. Pike National Forest, Colorado.

Figure 28. A planting crew at work setting out small trees. The man ahead digs the hole, and the man behind plants the tree. Wasatch $\mathrm{Na}$ tional Forest, Utah . . . . . .

Figure 29. At the Fort Valley Forest Experiment Station, Coconino National Forest, Arizona. A typical meteorological station. Forest officer measuring precipitation. Note the shelter which contains thermometers and also the electrically equipped instruments to record the direction and velocity of the wind . . 
Figure 30. Forest officer ascertaining the amount of evaporation from a free water surface. Fort Valley Forest Experiment Station, Flagstaff, Arizona . . . . . . . .

Figure 31. Forest Ranger with his pack horses traveling over his district. Meadow Creek, foot of Mt. Wilson, Montezuma National Forest, Colorado

Figure 32. A plank of Incense cedar affected by a disease known as "pin rot." By cutting the cedar timber when it is mature this can be largely avoided. Lassen National Forest, California. Photo by the author . .

Figure 33. The western pine forests will some day be a great source for naval stores. By distilling the crude resin of the Jeffrey pine a light volatile oil-abietene-is secured which has great healing and curative properties. Lassen National Forest, California. Photo by the author . . . . . . . .

Figure 34. A forest fire lookout station at the summit of Mt. Eddy. Mt. Shasta in the background. California . . . . . . . . .

Figure 35. A forest fire lookout station on the summit of Brokeoff Mountain, elevation 9,500 feet. Lassen National Forest, California. Photo by the author . . . . . . . .

Figure 36. Turner Mountain lookout station, Lassen National Forest, California. This is a 10 $\mathrm{ft}$. by $10 \mathrm{ft}$. cabin with a stove and with folding bed, table, and chairs. The forest officer stationed here watches for forest fires day and night throughout the fire season. Photo by the author

Figure 37. A fire line cut through the low bush-like growth of "Chaparral" on the Angeles Na- 
tional Forest, California. This "Chaparral" is of great value for regulating stream flow. The streams are used for water power, domestic purposes, and for irrigating many of the largest lemon and orange groves of southern California . . . . . .

Figure 38. A forest officers' temporary camp while fighting forest fires. Near Oregon National Forest, Oregon

Figure 39. Putting out a ground fire. Even if the fire does not burn the standing timber, it kills the young trees and so weakens the larger ones that they are easily blown over. Wallowa National Forest, Oregon . . . . .

Figure 40. Forest officers ready to leave a tool box for a forest fire in the vicinity. Such tool boxes as these are stationed at convenient places on National Forests ready for any emergency. Arapaho National Forest, Colorado

Figure 41. A forest fire on the Wasatch National Forest, Utah. Forest officers trying to stop a forest fire by cutting a fire line. Note the valuable growth of young trees which they are trying to save at the right . . .

Figure 42. A forest fire running in dense underbrush on one of the National Forests in Oregon . .

Figure 43. Men in a dense forest with heavy undergrowth clearing away brush to stop the fire as it is running down hill. Crater National Forest, Oregon . . . . . . .

Figure 44. Fire in a Lodgepole pine forest in Colorado. Arapalıo National Forest, Colorado . .

Figure 45. A mountain fire in "Chaparral" five hours after it started. Pasadena, California. 


\section{ILLUSTRATIONS}

Figure 46. A few years ago this was a green, luxuriant forest. Picture taken after the great fires of August 20, 1910, on the Cœur d'Alene $\mathrm{Na}$ tional Forest near Wallace, Idaho . .

Figure 47. The first evidence of insect attack are the reddish brown pitch tubes on the bark. Lodgepole pine infested by the mountain pine beetle. Lassen National Forest, California. Photo by the author . . . . . . .

Figure 48. The last stage of an insect-attacked tree. The tree is dead and the dry bark is falling off. Lassen National Forest, California. Photo by the author . . . . . .

Figure 49. Wrecked farm buildings due to flood of May 21, 1901, Nolichucky River, near Erwin, Tenn. This is one result of denuding the Appalachian Mountains of their forest cover

Figure 50. When steep hillsides are stripped of their forest growth, erosion results. Erosion has been especially serious in the Appalachian Mountains. View taken in Madison County, North Carolina

Figure 51. A fertile corn-field covered with sand, gravel and débris brought down from the mountains by floods. These farm lands are ruined beyond redemption. This could have been prevented by preserving the forests on the watershed of this river . . . . .

Figure 52. A view towards Mt. Adams and the headwaters of Lewis River. Council Lake in the foreground. National Forest lands lie at the headwaters of practically every large western rivcr. This means that the water supply for the western people used for domestic use, water power, and irrigation is being protected from pollution and destruc- 
tion. View taken on the Rainier National Forest, Washington . . . . . . . 172

Figure 53. A large storage reservoir used to irrigate the ranches in the valley below. Elevation 10,500 feet. Battlement National Forest, Colorado. Photo by the author . . .

Figure 54. A sheep herder's camp used temporarily by Forest Service timber cruisers. Elevation about 10,000 feet. Battlement National Forest, Colorado. Photo by the author.

Figure 55. View taken in the Coast Range mountains of California where Sugar pine and Douglas fir are the principal trees. Klamath $\mathrm{Na}$ tional Forest, California. Photo by the author

Figure 56. A typical mountain scene in the California Coast Range. On these steep slopes a forest cover is of vital importance. Klamath National Forest, California. Photo by the author

Figure 57. A forest officer at work on a high mountain peak making a plane-table survey and timber estimate of National Forest lands. Photo by the author . . . . . .

Figure 58. A government timber cruiser's summer camp. These cruisers get a fairly accurate estimate of Uncle Sam's timber resources at a cost of from 2 to 5 cents an acre. Photo by the author

Figure 59. Forest officers moving camp while engaged in winter reconnoissance work. All food, beds, and clothing are packed on "Alaska" sleds and drawn by the men themselves. Photo by the author . . . . . . . . 


\section{ILLUSTRATIONS}

lxvii

FACING

PAGE

Figure 60. A winter reconnoissance camp showing snow-shoes, skis, "Alaska" sleds, and bull hide used to repair the webbing on the snowshoes. Lassen National Forest, California. Plioto by the author . . . . . .

Figure 61. A group of giant redwoods. Santa Cruz County, California . . . . . .

Figure 62. A big Sugar pine tree about six feet in diameter. This is the most valuable timber species in California. Photo by the author

Figure 63. A Western Yellow pine forest in California. These trees are from four to six feet in diameter and from 150 to 200 feet high. Note the Forest Service timber cruiser measuring the tree at the left. Photo by the author.

Figure 64. Logging in California. Powerful steam engines pull the logs from the woods to the railroad and load them on flat cars. Photo by the author . . . . . . . .

Figure 65. The loaded flat cars reach the saw-mill where the logs are unloaded and sawn into lumber. During the fiscal year 1917 timber sales on the National Forests brought into the National Treasury almost $\$ 1,700$,000.00. Photo by the author

Figure 66. Scene in Montana. Forest officers constructing a telephone line through the Flathead National Forest . . . . . .

Figure 67. Forest Ranger, accompanied by a lumberman, marking National Forest timber for cutting in a timber sale. Coconino National Forest, Arizona . . . . . . .

Figure 68. An excellent illustration showing the difference between unrestricted logging as practiced by lumbermen, and conservative log- 
ging as practiced by the Forest Service. In the foreground is the unrestricted logging which strips the soil of every stick of timber both large and small; in the background is the Forest Service logging area which preserves the young growth to insure a future supply of timber for the West. Bitterroot National Forest, Montana . . . .

Figure 69. View showing the Forest Service method of piling the brush and débris after logging, and also how stump heights are kept down to prevent waste. New Mexico. . .

Figure 70. A tie-cutting operation on a National Forest. These piles of railroad ties are being inspected, stamped, and counted by Forest rangers. From this point the ties are "skidded" to the banks of a stream to be floated to the shipping point. Near Evanston, Wyoming .

Figure 71. Brush piles on a cut-over area before burning. Forest Service methods aim to clean up the forest after logging so that forest fires have less inflammable material to feed on. Bitterroot National Forest, Montana .

Figure 72. At a time of the year when there is least danger from fire the brush piles are burned. Missoula National Forest, Montana . .

Figure 73. Counting sheep as they leave the corral. Sheep and cattle are pastured on the $\mathrm{Na}$ tional Forests at so many cents per head, hence they must be counted before they enter in the spring. Wasatch National Forest, Utah

Figure 74. Logging National Forest timber. Santa Fe National Forest, New Mexico . . . . 


\section{ILLUSTRATIONS}

lxix

FACING

PAGE

Figure 75. Sheep grazing on the Montezuma National fiorest at the foot of Mt. Wilson, Colorado. Over 7,500,000 sheep and goats grazed on the National Forests during the fiscal year 1917

Figure 76. Grazing cattle on a National Forest in Colorado. Permits were issued during 1917 to graze over 2,000,000 cattle, horses, and swine on the National Forests . . . .

Figure 77. North Clear Creek Falls, Rio Grande National Forest, Colorado. The National Forests contain about one-third of all the potential water-power resources of the United States . . . . . . . .

Figure 78. The power plant of the Colorado Power Company, on the Grand River, Holy Cross National Forest, Colorado. Every fiscal year there is a substantial increase in water power development on the National Forests

Figure 79. This is only one of the thousands of streams in the National Forests of the West capable of generating electric power. It has been estimated that over 40 per cent. of the water resources of the Western States are included in the National Forests. Photo by the author

Figure 80. View in the famous orange belt of San Bernardino County, California. These orchards depend absolutely upon irrigation. The watersheds from which the necessary water comes are in the National Forests and are protected by the Forest Service. Some of the smaller watersheds in these mountains are said to irrigate orchards valued at $\$ 10$,000,000 



\section{OUR NATIONAL FORESTS}

\section{CHAPTER I}

\section{THE CREATION AND ORGANIZATION OF THE NATIONAL FORESTS}

ECONOMIC CONDITIONS WHICH LED TO FOREST CONSERVATION

In order that the reader may fully appreciate the gigantic task that has been accomplished in bringing the National Forest administration and organization to its present state of development, it is necessary to briefly sketch the conditions that led up to the inauguration of the Federal Forest Policy before we stop to consider that policy and the establishment and organization of National Forests.

Prodigality Leads Finally to Conservation. Every great movement, which has for its object the betterment of the lot of mankind, lags far behind the times. There must be an actual economic need before a new movement can be expected to take 
root and flourish. Forest conservation had no place in the household economy of nations that had forests in superabundance. Their forests were used with prodigality. It seems to be a great human failing to use natural resources lavishly when the supply is apparently unlimited, and to practice frugality only when the end of a resource is in sight. Thus we find in the pages of forestry history that all nations have begun to husband their forest resources only after having felt the pinch of want. In our country history repeats itself and our federal policy of forest conservation properly begins at the time that the national conscience was awakened to the realization that if we did not practice economy with our forest resources we would some day be without an adequate supply of timber and forage, and be confronted with other dangers and calamities that follow the destruction of forests.

The March of Forest Destruction. When the London Company settled at Jamestown, Virginia, in 1607 it found that unlimited pine and hardwood forests confronted it on every side. Nor did these early settlers ever find a way out of this forested wilderness except by clearings made with the ax. When the Pilgrim Fathers landed at Cape 
Cod in 1620 they found similar forests stretching in all directions from their town-site. After the Atlantic seaboard became pretty well settled the home-builders began moving westward through New York, Pennsylvania, and what is now Ohio. Still nothing but unbroken, virgin forests were encountered. Westward to the Mississippi civilization advanced and still forests reigned supreme. Then the Middle West, the Rocky Mountain region, and finally the Pacific Coast regions were settled. During 140 years civilization has spread from coast to coast and of that vast wilderness of forest there is left only a remnant here and there. 'The giant pines that sheltered De Soto and his thousand followers on their ill-fated expedition in 1541 to the Mississippi River have long since disappeared. Along the Allegheny and Appalachian ranges the vast forests that once harbored the hostile Narragansetts and Iroquois are now but a memory. The giant oak, ash, and cypress forests of the Mississippi Valley are rapidly being decimated by the big saw-mills that work night and day to outdo each other. In the north the dense and magnificent forests of white pine that greeted Father Marquette, when he planted his missionary station at Sault Ste. 
Marie in 1668, have been laid low. Unproductive wastes, sandy barrens, and useless underbrush now greet the eye. In fact the pine forests which covered the greater part of Michigan, Wisconsin, and Minnesota have been leveled by the woodman's ax. The army of lumbermen has moved now to the Coast to again turn virgin timberlands into unproductive wastes.

Thus forest destruction has followed civilization. Statistics show very vividly how gradually one large lumbering center after another has become exhausted, often leaving behind desolation and business depression. In these large centers thriving towns sprang up only to disappear again after the removal of the forest wealth. In 1850 about 55 per cent. of the annual cut of lumber came from the New England States; even as late as 1865 New York furnished more lumber than any State in the Union. By 1890 Michigan had reached the zenith of its production and in that year the Lake States furnished 36 per cent. of the lumber cut. By 1909 the Southern States had increased their cut to over 50 per cent. of the total of the country. In 1913 the cut of the State of Washington was the largest ever recorded for that State or for any other State, 
even outdoing Michigan during its Golden Age. In 1915 about 20 per cent. of the cut came from the Coast but the South still furnished almost $\mathbf{5 0}$ per cent.

Our Lumber and Water Supply Imperiled. In our prodigal use of our forest resources we have become the most lavish users of wood in the world. While the annual consumption per capita for France is about 25 cubic feet, and that of Germany about 40 cubic feet, our per capita consumption is in the neighborhood of 250 cubic feet. And the most terrible thing about our reckless methods has been that we have wasted by crude lumbering methods and we have let great forest fires consume many times as much lumber as we have used. There have been vast public and private losses through unnecessary forest fires which not only consumed millions of dollars' worth of timber every year, but which also cost the lives of thousands of settlers. Then, as every one knows, by being grossly negligent with our forests, our rivers have visited their wrath upon the unfortunate people in the valleys. Many streams have become raging torrents in the spring and only chains of stagnant pools in the summer, thus destroying their value for water 
power and irrigation. Cotton mills, which formerly used water power all the year round, now must depend upon more expensive steam power generated by coal to keep their mills running in times of water shortage, while during high water there is the great danger that the entire factory might be swept away.

THE FIRST STEPS IN FEDERAL FOREST CONSERVATION

Gradually the national conscience became awakened to the need of a more rational use of our forest resources. But it was not until after the Civil War that the first steps were taken. As was to be expected, the States in which forest destruction had reached its worst stages were the first to attempt to mend their ways, thus leading the way along which the Federal Government was soon to follow.

The Upbuilding of the West. The decade following the Civil War is marked by the construction of some of our great trans-continental railroads and the consequent development of the great western country. In fact between 1865 and 1875 the railroad mileage of the United States doubled. The first trans-continental railroad, the Union 
Pacific, was completed in 1869. Others soon followed. To encourage construction and settlement vast tracts of land were granted to the railroad companies by the Government, and with the land much valuable timber passed from government ownership. After the construction of the railroads towns and villages sprang up like mushrooms. As was to be expected with this increased development the destruction of our forests received an added impetus. The Lake States, then the center of the lumber industry, began to take alarm at the rapidity with which their hillsides were being denuded. Destructive lumbering, usually followed by devastáting forest fires, was fast decimating the virgin pine forests. The young growth that had escaped the lumberman's ax fell a prey to forest fires which soon took the form of annual conflagrations. As the population increased the new sections of the country were settled, and as manufacturing operations were extended timber was getting higher in price.

The Lake States First to Act. The first attempt to remedy the situation was made by the State of Wisconsin. In $\mathbf{1 8 6 7}$ the Wisconsin legislature suggested a committee who should report 
upon the destruction of Wisconsin's forests. The next year Michigan took a similar step and in 1869 the Maine legislature began to look into their waning supply by appointing a committee to estimate the standing timber of the State. As early as this observations and calculations upon the rate of consumption of lumber pointed to a not far distant wood famine.

The First Federal Steps. The first step taken by the federal authorities was at the urgent request of the Statistician of the Department of Agriculture in 1870. At that time lands were recognized as being either "improved" or "unimproved" farm lands. He recommended that the category of "unimproved farm lands" be subdivided into "woodlands" and "other unimproved lands." By thus dividing off woodlands from other unimproved farm lands more attention was concentrated upon the former. This attention was manifested in the investigations that followed shortly in which it was estimated that 39 per cent. of the area of the country was in woodland. This was the first and most logical step toward taking an inventory of our forest resources.

Another early attempt to assist in forest conser- 
vation was an attempt to reforest the treeless plains of our Western States. On March 3, 1873, the 'Timber Culture Act was passed by Congress by which the planting to timber of 40 acres of land in the treeless territories conferred the title to $\mathbf{1 6 0}$ acres of public domain. At first this act seemed to work out as intended but it did not take very many years before it proved a dismal failure. Settlers had no knowledge of planting trees; the restrictions of the act could not be enforced, and the act was open to other abuses. The act was finally repealed in 1891. Many similar laws for encouraging the planting of timber were passed by the legislatures of some of the Middle Western States, but all met with little success. In 1874 Nebraska inaugurated Arbor Day. By this act of the legislature the second Wednesday in April of each year was set aside for planting trees. Other States have followed the example of Nebraska, so that to-day almost every State provides one day in the year for planting trees. Thus Arbor Day has become practically a national institution.

The Act of August 16, 1876. The first constructive piece of legislation enacted by the Congress of the United States was the Act of August 
16, 1876. This was the first of a series of Acts passed by Congress which, although occurring many years apart in some cases, put forest conservation upon a firm basis. Under the first act the Commissioner of Agriculture was directed:

"To appoint some man of approved attainments who is practically well acquainted with methods of statistical inquiry and who has evinced an intimate acquaintance with questions relating to the national wants in regard to timber, to prosecute investigations and inquiries with the view of ascertaining the annual amount of consumption, importation, and exportation of timber and other forest products; the probable supply for future wants; the means best adapted to their preservation and renewal; the influence of forests upon climate and the means that have been successfully applied in foreign countries, or that may be deemed applicable in this country for the preservation and restoration or planting of forests, and to report upon the same to the Commissioner of Agriculture, to be by him in a separate report transmitted to Congress."

Dr. Franklin B. Hough, an active, untiring, and intelligent scholar, was the first man to be appointed by this act. As Commissioner of Forestry he prepared the first report and submitted it to Congress. The next year, in 1877, Congress granted its first appropriation of $\$ 6,000$, "for the purpose of obtaining other facts and information preparatory to establishing a Division of Forestry." 
Further Work Under the Act. The office of Commissioner of Forestry gradually enlarged the scope of its duties and functions. Five years later, due to the ever-increasing importance of the subject, a distinct division, the Division of Forestry, was established in the Department of Agriculture. The duties and powers of this Division were "to devote itself exclusively to such investigations of the subject as would tend to the fullest development of the resources of the country in that respect, to discover the best methods of managing and preserving our waning forests and to maintain in all its bearings the universal interest involved in that industry."

In 1881 an agent of the Department was sent to Europe to study the work of forestry there. In 1882 the American Forestry Congress was organized. This organization had for its object the discussion and dissemination of the important facts of forestry, and while strictly a private body, had a considerable influence in later years in educating the people to the needs of forestry and in helping to establish a rational forest policy in the United States. Its first meeting took place in Cincinnati. At a second meeting held the same 
year in Montreal the name was changed to the American Forestry Association and since then has been the center of all private efforts to advance the forestry movement. In 1898 this association began the publication of a propagandist journal which is now called American Forestry. In 1884 the duty of making experiments with timber was added to the functions of the Division. The next year the collecting and distribution of valuable economic tree seeds was begun. In 1886 the study of the biology of some of our important timber trees was taken up, while in the following year silvicultural problems first engaged the attention of the Division.

THE FIRST FOREST RESERVES ESTABLISHED MARCH 30, 1891

The Situation Before 1891. Before 1891 the Division of Forestry was simply a bureau of information. In general the information supplied was of a twofold nature. It was technical in so far as it related to the management of private woodlands and statistical in so far as the knowledge of the conditions of our forest resources induced the application of forestry principles. Up 
to that date Congress had neither appropriated enough money for efficient outdoor work nor did she attempt to put any government woodlands under the control of the Division. Therefore there had been no management because there were no forests to manage. This one-sided development of the forestry work of the Division was greatly impeding a rational development of the forest conservation movement.

The Need of a Forest Policy. The need for a well-defined forest policy with respect to the government forest lands now began to be felt. Railroad land grants, the Homestead Act, Preëmption claims, and the Timber and Stone Act were taking much valuable timberland out of government ownership. People secured claims under these acts merely for the timber that was on them. The purposes of the laws and acts of Congress were being fraudulently evaded. Also the Government had restrictive and protective laws in regard to its lands, but it could not enforce them on account of lack of appropriations with which to maintain an administrative and protective organization. The time was now ripe for an executive policy to manage the woodlands that still remained in the possession 


\section{4}

OUR NATIONAL FORESTS

of the Government before it was too late to save what was left.

The Act of March 3, 1891. The Division of Forestry was designed by the nature of its duties to be more than a bureau of information. The existence of a governmental department to promulgate forestry principles while the Government itself had made no provision to apply such principles to its own permanent timberlands was an incongruity that suggested further legislative action. This was in part supplied by the law of March 3, 1891, which conferred upon the President the power to establish Forest Reservations. The first exercise of power under this act was the presidential proclamation creating the Yellowstone Park Timber Land Reserve under President Harrison on March 30, 1891. This was probably the wisest step yet taken in the development of a National Forest policy; but, unfortunately, the act left the Division simply a bureau of information as it was before.

AN ANOMALOUS CONDITION-FOREST RESERVES WITHOUT FOREST ADMINISTRATION

The Need of Administration on the Reserves. At first thought it will be seen that this piece of 
legislation must necessarily remain inoperative unless it were followed by the establishment of a proper administration of the Reserves based upon sound forestry principles. Furthermore, the law withdrew from public use all such lands that might be acquired under it. It was now easy for the Government to acquire lands; the question that next presented itself was how to protect and regulate the use of these new acquisitions. Forest protection cannot be secured without forest rangers and forest guards; nor forest management without technical foresters. The very reasons for establishing the Reserves would point to the absolute need of a-system of managing them. These reasons were briefly:

"to prevent annual conflagrations; to prevent useless destruction of life and property by fires, etc.; to provide benefit and revenue from the sale of forest products, fuels, and timbers; to administer this resource for future benefit; to increase the stock of game; to promote the development of the country; to give regular empioyment to a professional staff; to secure continuous supplies of wood and to get the maximum amount of good from each acre."

Such arguments as these assume the presence of a force of men to protect and administrate these Reserves. 
More Reserves Created. In spite of this serious fault in the Act of March 3, 1891, more Forest Reservations were created. By 1894 Presidents Harrison and Cleveland had created about 17,500,000 acres and on a single day, February 22, 1897, President Cleveland proclaimed over 20,000,000 acres. By the close of 1897 a total of almost 40,000,000 acres of Forest Reserves had been established.

During the six years following the law giving the President power to establish Reserves, the Reserves were under the jurisdiction of the General Land Office. The appropriations of Congress were small, amounting to less than $\$ 30,000$ annually. Such appropriations were used mainly for testing timber strength and the conditions affecting quality.

THE ADMINISTRATION OF THE RESERVES UNDER THE GENERAL LAND OFFICE

The Act of June 4, 189\%. The Secretary of the Interior in 1896 requested the National Academy of Sciences, the legally constituted advisor of the Government in scientific matter's, to investigate, report upon, and recommend a National Forest policy. 'This resulted in the Act of June 4, 1897, 
under which, with subsequent amendments, the $\mathrm{Na}$ tional Forests are now being administered. Under this act the Reserves remained in the hands of the General Land Office, Department of the Interior. It charged this office with the administration and protection of the Forest Reservations. Later the Geological Survey was charged with surveying and mapping them, and the Division of Forestry was asked to give technical advice. It is very evident that the Division of Forestry containing all the trained scientific staff had no relation to the government forestry work except as the offices of the Department of the Interior might apply for assistance or advice. - It is true that an important step had been taken, but the complete separation of the administration by the General Land Office and the force of trained men in the Division of Forestry was a serious defect.

The Act of June 4 might be called the Magna Charta of national forestry. The U. S. Geological Survey undertook the task of surveying, classifying, and describing the Forest Reservations. At a cost of about one and one-half million dollars over 70,000,000 acres of Forest Reserves were mapped and described. The General Land Office undertook 
the administration and Forest Superintendents and Rangers were appointed to take charge of the Reservations. The rules and regulations for administering the Reserves were formulated by the Commissioner of the General Land Office.

The Division of Forestry in 1898. On July 1, 1898, the Division of Forestry employed 11 persons, 6 clerical and 5 scientific. There were also some collaborators and student assistants. There was no field equipment and no field work. But in the fall of 1898 an important step was taken. From that time on the Division of Forestry offered practical assistance to forest owners and thus it shifted its field of activity from the desk to the woods. The lumbermen were met on their own grounds and actual forest management for purely commercial ends was undertaken by well known lumbermen. From that time dates the solution of specific problems of forest management and the development of efficient methods of attacking them. The work of the Division at this time, therefore, consisted of activities along 4 distinct lines: that of working plans, (2) that of economic tree planting, (3) that of special investigations, and (4) that of office work. Thus it will be seen, even at 
this late date the Division had practically nothing to say about the scientific forestry methods which should be used on the Reservations.

The Bureau of Forestry. In 1901 the Division of Forestry was raised to the rank of a Bureau, but this was a change in name only and carried with it no change in the handling of the Government's vast forest resources.

THE CONSOLIDATION OF THE FORESTRY WORK IN THE DEPARTMENT OF AGRICULTURE IN 1905

The Act of February 1, 1905 . The necessity of consolidating the various branches of government forest work became apparent and was urged upon Congress by President Roosevelt and by the executive officers concerned. This was finally accomplished by the act of February 1, 1905, by which entire jurisdiction over the Forest Reserves was transferred to the Secretary of Agriculture. Matters of surveying and passage of title, however, were still kept under the jurisdiction of the General Land Office. By this act the Division of Forestry for the first time in its career became an administrative organization. On July 1 of the same year the Bureau of Forestry became the Forest 
Service and in 1907 the change of name from "Forest Reserves" to "National Forests" was made to correct the impression that the forests were like reserves which had been withdrawn from use.

Early Forestry Education and Literature. The Act of February 1, 1905, was the final step which established the federal policy with regard to our National Forests. At this stage it will be interesting to note briefly the status of the science of American Forestry and of forestry education. As late as the spring of 1898 there was no science or literature on American Forestry, nor could education in the subject be procured in the country. But soon thereafter several forestry schools were established, namely, Cornell Forestry School in 1898, Yale School of Forestry and Biltmore Forest School in 1899, and the University of Michigan Forestry School in 1903. The beginning of the twentieth century saw the first professional foresters graduated and taking upon themselves the task of applying scientific forestry methods to the $\mathrm{Na}$ tional Forests. Further evidence of the growth of the profession of forestry was the organization of the Society of American Foresters in 1900. The first professional journal was started in 1902 as the 
Forestry Quarterly, and other scientific forestry literature was issued by the Government. The scientific knowledge gathered in the field work since 1898 has taken the form of a rapidly growing literature on the subject which has formed the basis of the science of American Forestry.

Changes in the Forest Service Personnel. By 1905 the work of the Forest Service had increased to such an extent that the number of employees was increased to 821. With the opening of the forestry schools, professional foresters became available and the National Forests then began to be put into the hands of expert scientific men. Gradually the old type of untrained, non-scientific woodsman is being replaced by the trained forester. In addition, the entire force was made a part of the classified Civil Service and the plan of political appointees was banished forever.

More National Forests Created. While the administration of the National Forests was being adjusted the area of National Forests was constantly being increased. To the 40,000,000 acres of Reserves set aside by Presidents Harrison and Cleveland before 1897, President McKinley added over $7,000,000$ acres until 1901. When Roosevelt be- 
came President the National Forest policy received an added impetus and vigor. Being a great lover of the out-of-door-life and being especially well acquainted, on account of his extensive travels, with the great western country, President Roosevelt threw his powerful influence into the balance. With the close coöperation of Mr. Gifford Pinchot, his warm personal friend, and at that time the Chief Forester, Mr. Roosevelt set aside between 1901 and 1909 over 148,000,000 acres of National Forests, more than three times as much as had been set aside by all his predecessors together. Since 1909 a careful adjustment of the boundaries has been going on, both Presidents Taft and Wilson adding small areas here and there, which were found valuable for forestry purposes, or eliminating small areas found to have no value. Acts of Congress passed since 1907 prohibit the addition by the President to the National Forests already established in Washington, Oregon, California, Idaho, Montana, Wyoming, and Colorado. Additions can be made in these States only by special act of Congress. A number of such acts have been passed; some of them upon petitions of the people in these States.

The Growth of the Forest Service. The growth 
of the Forest Service between 1897 and 1917 is little short of marvelous. The number of its employees has increased from 61 in 1898 to 3,544 on June 30, 1917. The annual appropriations have increased from less than $\$ 30,000$ in 1897 to $\$ 5,712,-$ 275 for the fiscal year 1918. But besides this appropriation for 1918 the Weeks Law calls for an expenditure of $\$ 2,100,000$ and the Federal Aid Road Act for $\$ 1,000,000$ more. 'The receipts of the National Forests have also increased by leaps and bounds. In 1897 the receipts were practically negligible in amount but by 1906 they had reached approximately $\$ 800,000$. In the fiscal year 1917 they were more than $\$ 3,457,000$.

Recent Modifications in the Organization. Further slight modifications in the organization, as established in 1905, were made since that date. Before 1908 all the work of the Forests was supervised from the main office in Washington and this arrangement caused much delay and inconvenience in carrying on the business of the Forests. In the fall of 1908 six administrative districts were established, to which another was added in 1914. By this arrangement the National Forests are divided into 7 groups and each group has a district head- 


\section{OUR NATIONAL FORESTS}

quarters in a large city or town centrally located in the group. The District Office acts as sort of clearing house for all National Forest business. All matters in the administration and protection of the National Forests that cannot be settled on the Forest or appear to be of general importance to the district are taken to the District Office, which is in charge of a District Forester and several assistants. Beginning in 1909 Forest Experiment Stations were established in each district and in 1910 the Forest Products Laboratory, the first one of its kind in the world, was formally opened at Madison, Wisconsin. The Weeks Law, passed on March 1, 1911, provides for the acquisition of forest lands on the watersheds of navigable streams in the Appalachian and White Mountains. Up to June 30, 1917, over $1,500,000$ acres have been approved for purchase in these mountains. The Pisgah National Forest in North Carolina was recently organized from purchased lands.

THE PRESENT ORGANIZATION OF THE FOREST SERVICE

The Administrative Districts. The administration of the National Forests and the conduct of all matters relating to forestry which have been placed 
upon the Department of Agriculture are in charge of the Forester whose office is in Washington, D. C. To facilitate the administration of the Forests 7 districts have been established with headquarters in the following places:

District 1. (Montana, northeastern Washington, northern Idaho, and northwestern South Dakota) Missoula, Montana.

District 2. (Colorado, Wyoming, the remainder of South Dakota, Nebraska, northern Michigan, and northern Minnesota) Denver, Colorado.

District 3. (Most of Arizona and New Mexico) Albuquerque, New Mexico.

District 4. (Utah, southern Idaho, western Wyoming, eastern and central Nevada, and northwestern Arizona) - Ogden, Utah.

District 5. (California and western Nevada) San Francisco, California.

District 6. (Washington, Oregon, and Alaska) Portland, Oregon.

District 7. (Arkansas, Florida, Oklahoma, and the newly purchased areas in South Carolina, Georgia, North Carolina, Tennessee, Virginia, West Virginia, New Hampshire, Maine, and Alabama,) Washington, D. C.

Each administrative district embraces a number of National Forests and is in charge of a Forest officer known as the District Forester who is responsible to the Forester for all administrative and technical 
work performed within the district. Each District Forester is aided by several assistants and by specialists in various lines of work. Each National Forest is in charge of a Forest Supervisor who may have a Deputy and a Forest Assistant or Forest Examiner to assist him if the amount of business on a National Forest warrants it. Each National Forest is subdivided into Ranger districts for the purpose of facilitating the protection work. Each Ranger district is in charge of a Ranger who may be assisted by other Rangers or Forest Guards.

The Washington Office. The work of the Forest Service in Washington is organized under the Office of Forester and the Branches of Operation, Lands, Silviculture, Research, Grazing, Engineering, and Acquisition of lands under the Weeks Law. The Office of Forester includes the Associate Forester, the Editor, the Dendrologist, the Chief of Accounts, besides Inspectors and Lumbermen. The Branch of Operation administers and supervises the business organization of the Forest Service and has general supervision of the personnel, quarters, equipment, and supplies of the Service and all the fire protection and permanent improvement work on the National Forests. The Branch of 
Lands examines and classifies lands in the Forests to determine their value for forest purposes, conducts the work in connection with claims on the Forests prior to proceedings before United States registers and receivers, and assists the Chief Engineer of the Service in handling matters in connection with the occupation and use of the National Forest lands for hydro-electric power purposes. The Branch of Silviculture supervises the sale and cutting of timber on the National Forests and coöperates with States in protecting forest lands under Section 2 of the Weeks Law. The Branch of Research has supervision over the investigative work of the Service, including silvicultural studies, studies of state forest conditions, investigations of the lumber and wood-using industries and lumber prices, and the investigative work carried on at the Forest Products Laboratory and the Forest Experiment Stations. The Branch of Grazing supervises the grazing of live stock upon the National Forests, allotting grazing privileges and dividing the ranges between different owners and classes of stock. It is also charged with the work of improving depleted grazing lands and of coöperating with the Federal and state authorities in the enforce- 
ment of stock quarantine regulations. The Branch of Engineering has to do with the proper designing and planning of roads, trails, and bridges; with the engineering problems involved in granting permits to hydro-electric plants in the Forests; and with the making of forest maps, surveys, improving the forest atlas, and other drafting work. The Branch of Acquisition of Lands under the Weeks Law has charge of examining and evaluating such lands which are offered for purchase and recommending suitable lands for purchase under the act.

The District Offices. Each District Office (of which there are 7) is organized in the main along the same lines as the Washington office. Each Branch in the Washington office is represented in the District Office by an Assistant District Forester or some similar official. The Office of the District Forester has in addition the Office of Solicitor (Forest Service Branch), which is in charge of an assistant to the Solicitor of the Department of Agriculture. He is the advisor to the District Forester in all matters of law which arise in the administration of the National Forests. His opinions are usually binding except that, in urgent cases, appeal may be taken to the Solicitor of the Depart- 


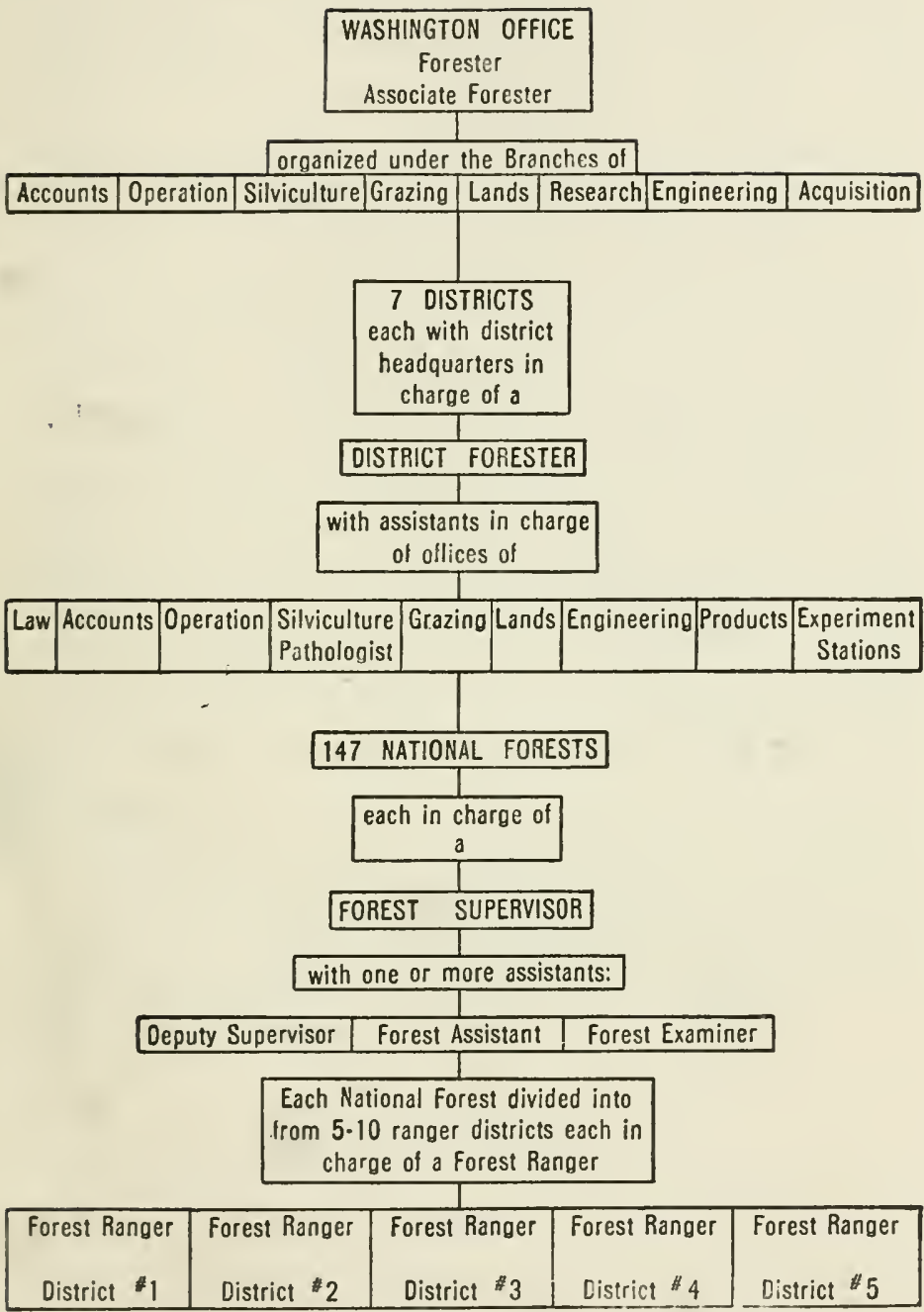



ment at Washington through the Forester. Many cases of law arise on the National Forests such as cases of timber, fire, and grazing trespass. All these are handled in the Office of the District Forester. The Office of Accounts in the districts is in charge of the District Fiscal Agent who is an assistant to the Chief of Accounts in the Washington Office. Three of the districts have a Branch of Products. The Experiment Stations in the districts are under the supervision of the District Forester and the men in charge of them bear the same relation to the District Office as the Supervisor of a National Forest. Most of the districts also have in the Office of Silviculture a Consulting Pathologist who has charge of all problems relating to tree diseases.

The following scheme will illustrate in a general way the organization of the Forest Service and show how the National Forests are administered at the present time: 


\section{CHAPTER II}

\section{THE ADMINISTRATION OF THE NA'TIONAL FORESTS}

Under the head of administration we must necessarily understand those factors which are essential to carry on the business of the National Forests. First of all we must consider the personnel, that is, the men that make up the organization by means of which the work on the Forests is done. Next we must learn how the money for this large enterprise is appropriated each year to carry on the work, and how it is divided up so that each National Forest gets an amount each year in proportion to its needs. Then again men and money are of little avail without tools, equipment, and supplies. The proper distribution of these to the 147 National Forests is no small business organization in itself. Lastly we must learn of the many permanent improvements which are made on the National Forests which are absolutely necessary for their proper administration, protection and use. No large con- 
structive forestry enterprise is complete without these. They consist of the construction of means of transportation, means of communication, and living quarters for the personnel; of extensive planting of young trees to reëstablish forests which have been destroyed by fires; the carrying on of research and experiments to aid in the development of the best methods of forestry; and the classification and segregation of agricultural lands and the establishment of permanent boundaries. All these matters must necessarily be considered before we attempt to learn about the protection and the utilization of the National Forests.

\section{PERSONNEL}

Duties of Forest Officers. Forest officers are the servants of the people and they are expected to assist in every way possible those who wish to use the resources of the Forests. Their first duty is to enforce the regulations under which all permits, leases, sales, and rentals are made. These regulations cover every phase of National Forest activity and in conducting business under them they must not let personal or other interests weigh against the good of the Forests. For the good of the Forest 
Service their conduct must be prompt and courteous and their business methods sensible and effective. They make it their business to prevent misunderstandings and violations of forest regulations rather than to correct mistakes after they have been made.

On the National Forests there are permanent employees and temporary employees. Under the former heading come the Forest Supervisor, the Deputy Supervisor, the Forest Assistant, the Forest Ranger, Lumbermen, Scalers, Planting Assistants, and Forest Clerks. Under the latter category come the Forest Guards, the Field Assistants, and the Temporary Laborers. All permanent positions are in the classified Civil Service. Vacancies are filled from a certified list of those who have passed a Civil Service examination or by promotion from the lower ranks.

The Forest Supervisor. A Forest Supervisor is in charge of each National Forest and he plans the work of the Forest and supervises its execution. He works, of course, under direct instruction from the District Forester and is responsible to him. When the amount of business on the Forest warrants it he is assisted by a Deputy Supervisor. 


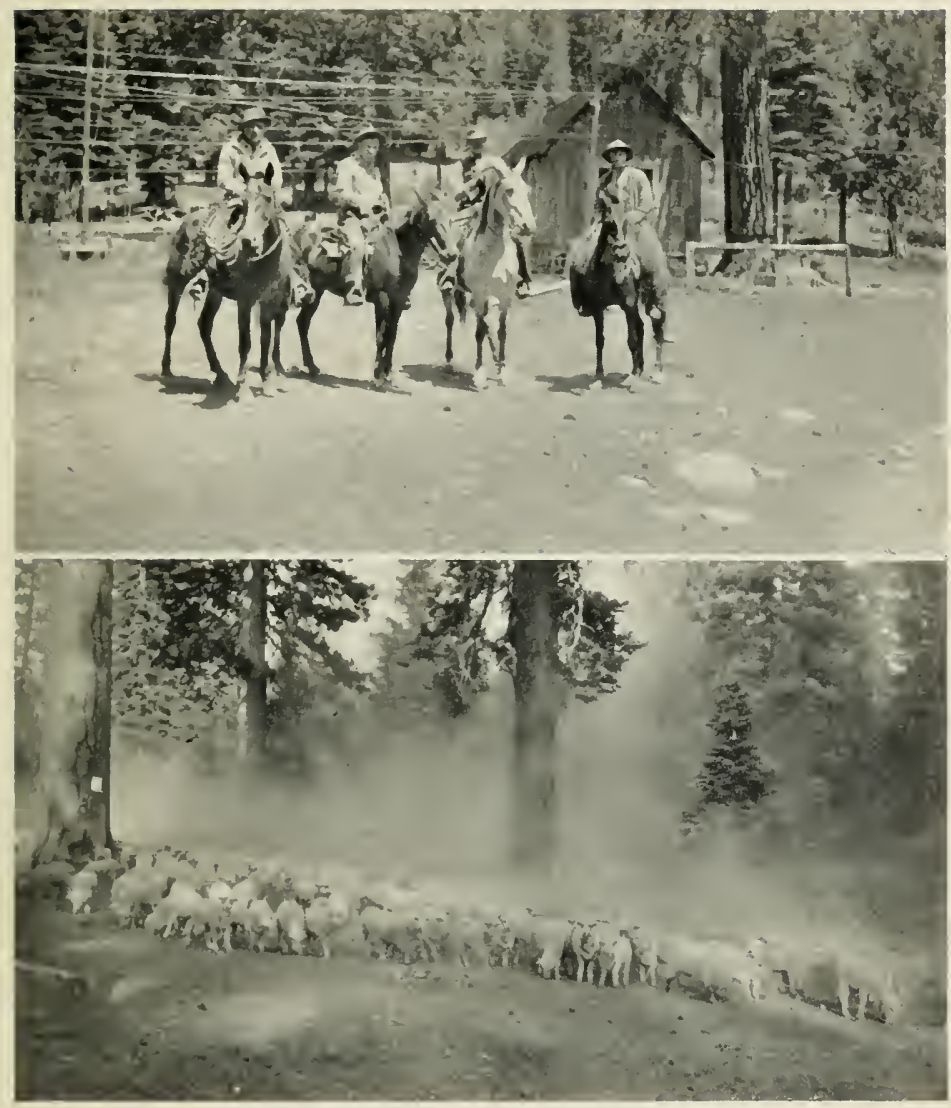

Figure 9. Forest officers in front of the Forest Supervisor"s summer headquarters. Note the many telephone wires that lead from the office. 'This is 50 miles from the railroad. Lassen National Forest, California.

Figure 10. Srene in front of the Forest Supervisor's headquarters. Shere leaving the National Forest summer range in the fall to go to winter range in the valley. Lassen National Forest, California. 



\section{ADMINISTRATION}

Both these positions are filled by the promotion of experienced men in the classified Civil Service. The Forest Supervisor's headquarters are located in towns conveniently situated with regard to the most important points in his Forest. The town is usually located on a railroad and centrally located with regard to the various Ranger districts of his Forest. His headquarters are usually the center of the system of roads and trails which covers his entire Forest. From his office also the telephone system radiates in all directions to his various District Rangers. In short, the Forest Supervisor's office is so situated that he has at all times full knowledge of all the activities of his Forest; he is therefore in a position to give advice and directions by telephone to his Rangers and other subordinates almost at any time of the day or night. Such intimate communication is of especial importance during the fire season.

Some Forests have two headquarters, one that is occupied in the winter and the other that is occupied in the summer. The summer quarters is usually most advantageously situated as far as the business of the Forest is concerned, but owing to deep snow, which seriously interferes with mail and tele- 
phone connections, a more accessible winter quarters is occupied from October to May.

The force of men the Forest Supervisor has working under him varies of course with the amount of work to be performed. The permanent force is usually from 10 to 15 men, which during the fire season may be increased to from 25 to 40 and in cases of great fire emergency sometimes to several hundred men, by the addition of temporary employees.

The Forest Assistant. The other permanent men on a National Forest are the Forest Assistant or Forest Examiner, Forest Rangers, and a Forest clerk with his assistant, the Stenographer and Typewriter. The Forest Assistant or Examiner ranks next to the Deputy and his work is directed by the Forest Supervisor, to whom he makes his reports. The Forest Assistant is the technical man of the Forest force, who upon making good is promoted to Forest Examiner. He is employed upon such technical lines of work as the examination and mapping of forest areas; reports on applications for the purchase of timber; marking, scaling, and managing timber sales; the survey of boundaries; and nursery and planting work. 
Not only is a Forest Assistant called upon to perform these various lines of technical work. The very nature of the country he is in indicates that he must be an all-round practical man. He must be able to ride, pack, and drive. He must often live alone and therefore must do his own cooking, washing, and take care of other personal needs. He must be strong and healthy and capable of undergoing hardships, at least be able to stand long days of walking, climbing, and horseback riding. His various duties and the different situations that arise often call for knowledge and practical ability as a carpenter, a mechanic, a plumber, an engineer, a surveyor, and many other lines of work. Perhaps more important than his education and ability are his personal qualifications. His temperament must be such that he must feel satisfied and contented under the most trying conditions. He must be able to do without most of the comforts of modern civilization for most of the time. For these reasons the country-bred western youths are more liable to make a success of the work than the city-bred easterner.

The Forest Ranger. The Forest Ranger's position is one of the most important and at the same 
time the most difficult positions on our National Forests.

The Forest Ranger's headquarters are usually at the nearest business center to his district and if that is not practicable permanent headquarters are provided on the Forest. In any case his station is located as near to the center of the business activity of his district as possible. If his headquarters are centrally located in his district, trails, roads, and telephone lines lead out from his cabin to all parts of his district. His station is built and maintained at government expense and usually has, besides his living quarters, a barn, tool-house, pasture, corral, and other necessary improvements.

The Forest Ranger performs such routine work as the supervision of timber sales, grazing, free use, special use, and other contracts and permits, the carrying out of the protection and improvement plans for his district, and other administrative duties. 'The average Forest Ranger has a territory of from $\mathbf{7 5 , 0 0 0}$ to $\mathbf{1 5 0 , 0 0 0}$ acres to take care of. On June 30, 1917, there were about 1,100 Forest Rangers employed on the National Forests who were assisted by orer 900 Assistant Forest Rangers and Forest Guards. The protective force 
was therefore about one man for every $\mathbf{7 7 , 8 0 0}$ acres or about 121 square miles.

The Forest Ranger must be a man who is physically sound and capable of enduring great hardships. He is often required to do heavy manual labor in fighting fire under the most trying conditions. For this reason he must have great endurance. They are usually men who have been brought up in timber work, on ranches or farms, or with the stock business. They are therefore thoroughly familiar with the region in which they are to be employed and especially acquainted with the rough, semi-primitive life which is characteristic of remote places in the $\mathbf{W}$ est.

He must be able to take care of himself and his horses in regions remote from settlement and supplies. He must be able to build trails, roads and cabins; he must be able to ride, pack, and drive and deal tactfully with all classes of people. He must know something about land surveying, estimating, and scaling timber; of logging, mining laws, and the live stock business. His duties include patrol to prevent fire and trespass; estimating, surveying, and marking timber; the supervision of cutting and similar work. He is authorized to issue permits, 
build cabins and trails, oversee grazing business, investigate mining and agricultural claims, report upon applications, and report upon and arrest for the violation of Forest laws and regulations.

The Forest Clerk. The Forest Clerk performs the clerical work and the book-keeping in the Forest Supervisor's office. He sometimes has a Stenographer and Typewriter to assist him and to do the mechanical work of correspondence. Lumbermen are specialists who are thoroughly well versed in all that pertains to logging, milling, scaling, and cruising timber. They are assigned temporarily to Forests where need for their work arises. Scalers are men thoroughly familiar with the art of scaling or measuring logs, ties, poles, cordwood and other forest products. Planting Assistants are specialists in nursery and planting work. Their duties include the preparation of seed beds, seed sowing, transplanting and care of seedlings, and field planting. They are assigned to the Forest Service nurseries.

Temporary Laborers, Forest Guards, and Field Assistants are employed during the field season when additional work on the National Forests warrants it. Forest Guards perform temporary 


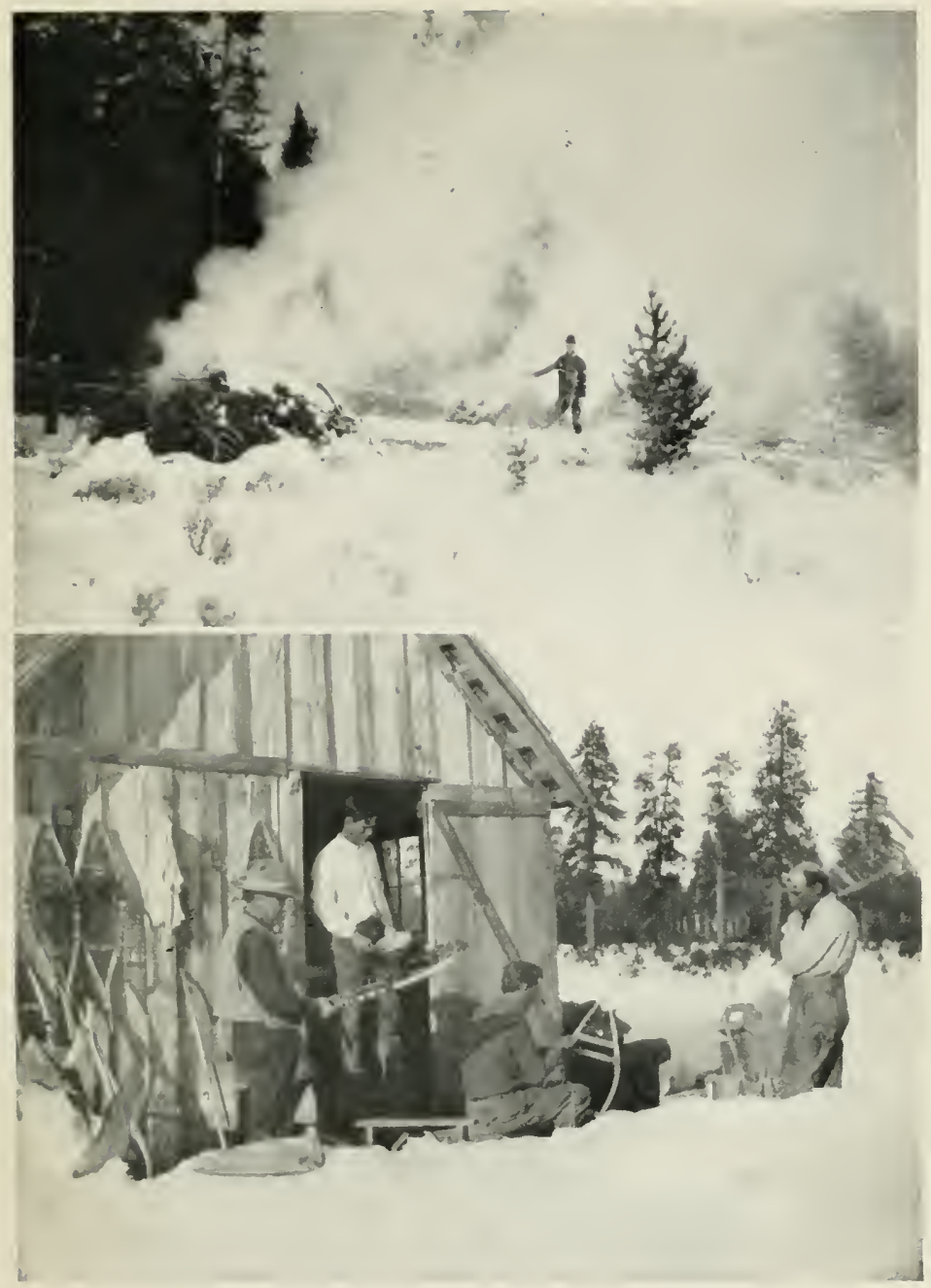

Tife Work of Fonest OfFicers ix tue Wixter

Figure 11. Forest officers and lmmberjacks burning the slauh resulting from a timber sale. The snow on the ground makes the hurning less dangerous. Washakie National Forest, Wyoming. Ploto by the anthor.

Fignre 12. Forest officers at a winter timber-cruising camp repairing snow shoes. Besides eruising the timber, these men make a logring map of the govermment lands, to show how the timber can best be taken out. Iassen National Forest, California. Photo by the anthor. 

protection, administrative, and improvement work; Field Assistants, usually students of forestry serving their apprenticeships, are usually employed at minor technical work and timber cruising; Temporary Laborers are employed by the day or month at any kind of improvement or maintenance work.

Forest Service Meetings. A general meeting of the Forest force is usually held annually to give the Forest officers the benefit of each other's experience, to keep in touch with the entire work of the Forest, and to promote "esprit-de-corps." The time and place of the meeting depends upon circumstances, but it is usually held at a time of the year when there is least danger from fire. Often joint meetings are held with the forces of adjacent Forests. This annual meeting idea is carried through the entire Forest Service. The Forest Supervisors in each administrative district usually meet at the district headquarters once a year and the District Foresters of all the districts together with representative officers from the Washington office usually meet annually at some centrally located district office such as the one at Ogden, Utah. These meetings assist greatly in keeping all the work in the various branches of the Service up to the same 
standard of efficiency, in avoiding mistakes by learning the experience of others, and in correlating and summarizing work done on similar problems in widely different regions.

HOW THE FOREST SERVICE APPROPRIATION IS ALLOTTED TO THE NATIONAL FORESTS

It is, indeed, a great task to distribute the money that is each year appropriated by Congress for the Forest Service so that the Washington Office, the District Offices, and the 147 National Forests each get their just share and so that each dollar buys the greatest amount of good for the whole people without extravagance or waste. To do this a large organization has been built up composed of business men who have absolutely no selfish interest at heart and among whom graft or favoritism is unknown and unheard of. It may be said without exaggeration that the business of the National Forests is on a thoroughly sound and efficient basis.

Forest Service Expenses. While for reasons already spoken of, the cash receipts are considerably below the expenses for running the Forests, the rapidly increasing system of roads, trails and telephone lines points not only to a constantly increas- 
ing use and service to the public but also as a consequence to increased financial returns.

The expenses of the Forest Service on the National Forests are of a two-fold character. There are costs of administration and protection on the one hand which might be called ordinary running expenses, and the costs of improvements, reforestation, and forest investigations on the other. The latter are really in the nature of investments, and do not properly fall into the category of operating costs. Yet they are absolutely necessary to the welfare of the Forests. They comprise expenditures for roads, trails, telephone lines, and similar improvements, the establishment of forests by the planting of young trees which have been destroyed by past fires, the carrying on of research and experiments to aid in the development of the best methods of forestry, and expenses connected with the classification and segregation of agricultural lands in the Forests. The establishment of permanent boundaries and the cost of making homestead and other surveys are also in the nature of investments. Such expenditures may be looked upon as money deposited in the bank to bear interest; they will not bring direct financial returns now 
but will produce great revenue many years hence.

The Agricultural A ppropriation Bill. 'The fiscal year in the Forest Service extends from July 1 of one year to June 30 of the next. Every year, in the Agricultural Appropriation Bill that comes before Congress, there is an appropriation for the Forest Service for its work. This appropriation is not in a lump sum but by allotments or funds. There is the fund for Fire Fighting, one for General Expenses, another for Statutory Salaries, another for Improvements, another for Emergency Fire conditions, and usually there are special appropriations for various purposes. For the fiscal year 1918 (extending from July 1, 1917, to June 30,1918 ) there are special appropriations for Land Classification, for purchasing land under the $W$ eeks Law, for coöperative fire protection under the Weeks Law, and for the Federal Aid Road Act.

The Ranger's Protection and Improvement Plans. Long before this bill reaches Congress every Forest Ranger on every National Forest, every Forest Supervisor, and every Branch of the Washington and the District Offices have been estimating how much money they will need to carry out the plans proposed for the next fiscal year. 
Each Forest Ranger works and studies over his plans for the next year with which he hopes to protect his district from fire. He plans and figures out what improvements are urgently necessary to make the remote parts of his district more accessible. He tries to arrive at a safe estimate of the cost of so many miles of trails, roads, and telephone lines, so many cabins, barns, corrals, etc., which he thinks are absolutely essential to the proper administration of his district, and he estimates the number of Forest Guards, lookout men, and patrol men he will need for the protection of his territory. Usually these items are summed up under his annual Improvement Plan and his Protection Plan respectively.

The Supervisor's Plans. When the Forest Supervisor receives such estimates and plans from each of his Forest Rangers he studies them over carefully and tries to decide in an impartial way what improvements are most necessary in each Ranger district and what additional men are necessary for the adequate protection of the region in question. He carefully weighs the arguments for and against each expenditure and decides what improvements must be made now and which ones it would be 
possible to postpone for one or more years without detriment to the work of his Forest as a whole. For in most cases the amount of necessary work to be done on each Ranger district is far in excess of the amount which the Forest Supervisor could approve owing to the inadequacy of the Forest Service funds. So, for the Forest Supervisor, it is merely a question of how low he can keep his estimates for money for the ensuing year until such a time when Congress will appropriate more money so that all the important and necessary work can be done. In most cases therefore the major part of all the expenditures recommended by the Forest Ranger is warranted, but the Forest Supervisor knows that he must cut all the estimates down considerably in order to bring the total Forest estimate reasonably near the amount he is likely to get, basing his judgment upon what he got the year before. Approval of Plans by the District Forester. The District Forester then gets the National Forest estimate from every one of his 25 or 30 Forest Supervisors and he in turn must decide what projects on each Forest are immediately necessary and which ones can be postponed. The same process is repeated in the Washington office when all the 
estimates from the District Foresters are received, and the Forester in turn sends to the Secretary of Agriculture his estimates by allotments or funds, which in turn are put before Congress. While Congress sometimes makes minor changes in the Forest Service appropriation, in most cases the bill is passed as it stands.

The District Fiscal Agent. The money appropriated by Congress is allotted to each district, and in turn to each National Forest and finally to each Ranger district by funds, such as General Expenses, Fire Fighting, Improvements, etc. In each district the financial matters are taken care of in the Office of-Accounts by the District Fiscal Agent. $\mathrm{He}$ is the Assistant of the Chief of the Forest Service Branch of the Division of Accounts of the Department of Agriculture and pays all the bills incurred by the district and receives all the money which comes in from the sale of National Forest resources. 'The amount of money appropriated for the district is credited to him and he disburses this appropriation in accordance with the Fiscal Regulations of the Department of Agriculture. No other officer is allowed to receive money for the sale of timber, forage, or other resources; in fact no 
other official in the District handles any of the Forest Service funds whatsoever.

All remittances by users of the National Forests are made to the U. S. District Depository. If a rancher has bought some timber from a Forest Ranger, he is given a letter of transmittal showing the amount of the purchase which he must send to the District Fiscal Agent with the amount necessary to pay for the timber. The letter of transmittal explains the purpose of the remittance.

Tax Money Paid to the States. Another interesting feature of the National Forest business is the money paid each State out of the annual receipts in lieu of taxes. It must be remembered that $\mathrm{Na}$ tional Forests do not pay taxes to the States in which they are located. On the other hand, if the National Forests were private property they would bring into the county and state treasuries yearly taxes. To compensate the State for the taxes lost in this way each National Forest pays to each county in proportion to the area of the National Forest lands located in that county a sum of money equal to 25 per cent. of the total gross receipts each fiscal year. From the receipts of the fiscal year 1917 this amounts to about $\$ 850,000$. It is 
provided that this money is to be expended for schools and roads in the county in which the $\mathrm{Na}$ tional Forests lie. Recently a law was passed giving the Secretary of Agriculture authority to expend an additional 10 per cent. of the National Forest receipts for the construction of roads and trails for the benefit of local communities. From the fiscal year 1917 this amounts to about $\$ 340,000$. These moneys for roads, trails, and schools are of course a great benefit to the mountain communities, since usually the amount of taxable property in such remote localities is small and hence the amount of taxes received is small. These allotments to the counties have helped to develop the communication systems of local communities and have also made the National Forests more accessible and useful.

THE EQUIPMENT AND SUPPLIES FOR THE NATIONAL FORESTS

The Property Auditor and Property Clerk. The depot for equipment, supplies, and blank forms is located at Ogden, Utah, and this office furnishes all the Forests in all the districts with most of the equipment necessary. The record of the property of the United States in the custody of the For- 
est Service is kept by a man called the Property Auditor. Requisitions for supplies and equipment are made by the Forest Supervisor to the Property Clerk. Government property is considered expendable or non-expendable depending upon its character. Each Forest has a Property Custodian who has charge of all the property assigned to the Forest. When property is received from the Property Clerk or if property is transferred from one forest officer to another, the Property Custodian must note the change on his records.

Blank Forms. The blank forms which are supplied by the Property Clerk are printed standard forms used in issuing permits, making contracts, reports, examinations, timber sale agreements, in short, those used in almost every business transaction of the Forest Service. Even timber estimates, tree measurements, and other similar public records are kept on standard printed forms for permanent uniform record.

Supplies. Supplies such as stationery, typewriters, pencils, ink, notebooks, paper for map work, compasses, measuring tapes, and a host of other articles are furnished upon requisition by the Property Clerk. Equipment such as filing cases, 
tables, chairs, typewriters, tree-measuring instruments, tents, cooking utensils, surveying instruments, snow shoes, skiis, knapsacks, water buckets, canteens, kodaks, and many other forms of equipment are furnished by the Property Clerk, although in cases of emergency some of these things may be purchased locally by Forest officers by the authority of the Forest Supervisor.

\section{NATIONAL FOREST IMPROVEMENTS}

The Need of Improvements. It is but natural, from their situation, that the National Forests represent pioneer conditions; conditions that one might expect to find in a wild, rugged, mountainous country. This was true to an extreme degree when the National Forests were first established and it is true in a very large degree even to-day, since the amount of time and money which it will be necessary to expend on the construction of improvements on the 155,000,000 acres of National Forests is something enormous. For a long time to come, then, the $\mathrm{Na}$ tional Forests will need improvements in order to make them secure against fire and in order to make the resources, now locked up, available. Proper protection and the fullest use of National Forest 
resources depend mainly upon facilities for transportation, communication, and control. All parts of the National Forests should be accessible by roads and trails; there should be telephone communication between settlements and Forest officers' headquarters and with the lookout stations; and in most cases suitable living accommodations must be provided for the field force. For the fullest use of the forage resources, water for the live stock must be developed and range fences constructed; to reduce the hazard and the cost and difficulty of controlling forest fires, firebreaks and other works must be constructed.

Transportation Facilities. Adequate facilities for travel and transportation are of first importance. Steam roads, electric roads, and boat lines are utilized in the National Forest transportation system as well as the existing roads and trails. Added to this, new roads and trails are being constructed every year to complete the already existing network.

The need for new roads and trails depends upon the number of them already existing, the value of the resources that it is necessary to make accessible, the fire liability, and the amount of unrealized rev- 


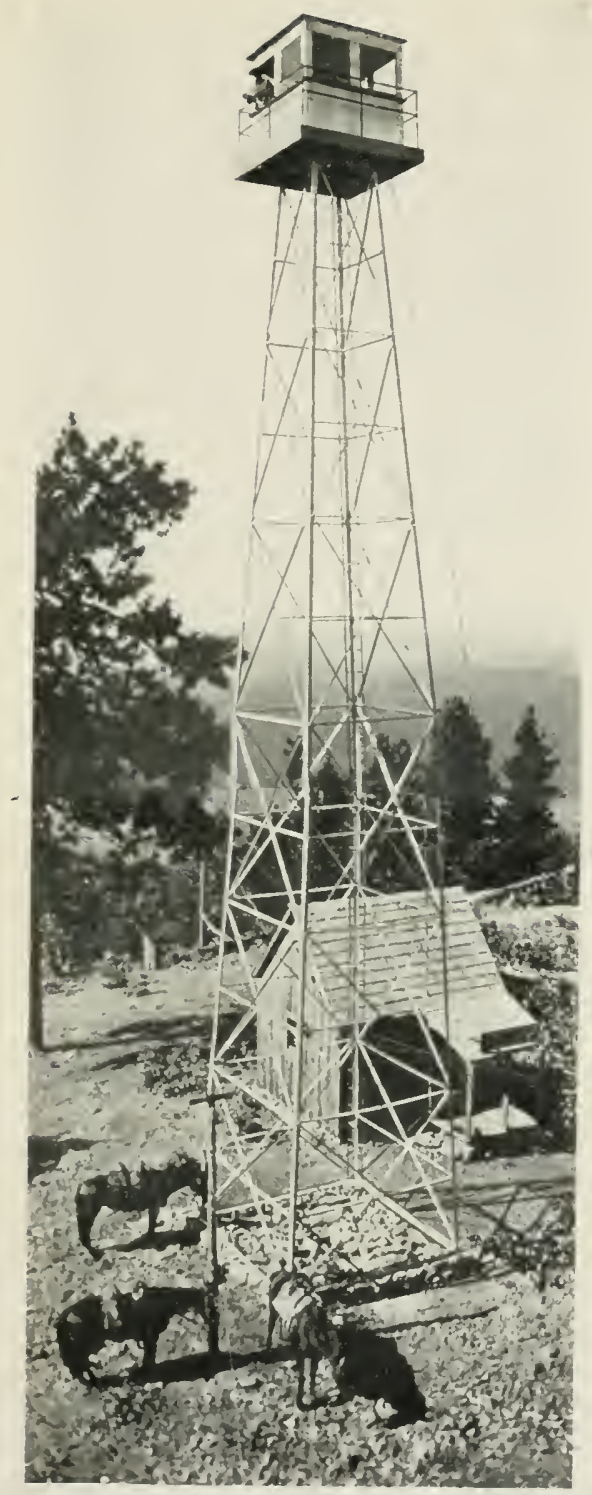

Figure 13. A forest fire looknut tower on Leek Springs Mountain. Eldorado National Forest. California 

enues due to lack of transportation facilities. If valuable grazing land or timber land can be made accessible there is good reason for building a new road. In many cases roads and trails are built to facilitate the protection of large remote areas from fire. Such areas may have large bodies of valuable timber which if destroyed by forest fires would involve a heavy loss. Even aside from valuable timber on an area, it is absolutely necessary when a forest fire breaks out to get to it with men and firefighting equipment in the shortest possible time before it spreads. If the fire gets to be a large one, many men with provisions, tents, fire-fighting tools, and other equipment must be transported to the scene of the fire. Any delay in the transportation of these things may prove fatal and may result in an uncontrollable conflagration.

The transportation system that is proposed for a National Forest, if the one that exists is inadequate, is usually planned many years ahead. The ultimate or ideal system is always kept in mind so that every mile of road or trail that is constructed is made a part of it. If not enough money is available for a good road, a trail is built along the line of the proposed road. Later this trail is widened 
into a permanent road. The Engineer connected with each District Office usually has charge of laying out big road projects. A few miles of permanent, good, dirt road with good grade is always preferred to many miles of poor road with heavy grade and improper drainage. A road and trail system is planned for each National Forest which will eventually place every portion of the Forest within a distance of at least $71 / 2$ miles of a wagon road. A pack-train can then transport supplies from the point to which they are delivered on the wagon road to any field camp and return in a single day.

In trail and road construction it is very often necessary to build bridges. Sometimes a very simple log bridge meets the need, but in bridging many large mountain torrents, which become very high and dangerous in the spring, large bridges are necessary. Cable suspension bridges and queen and king truss bridges are built where occasion arises for them, but only after being planned in detail and after the District Forester has approved their design and method of construction.

Very often navigable streams and lakes are used as a part of the transportation system on a $\mathrm{Na}$ tional Forest. On the 'Tahoe National Forest in 


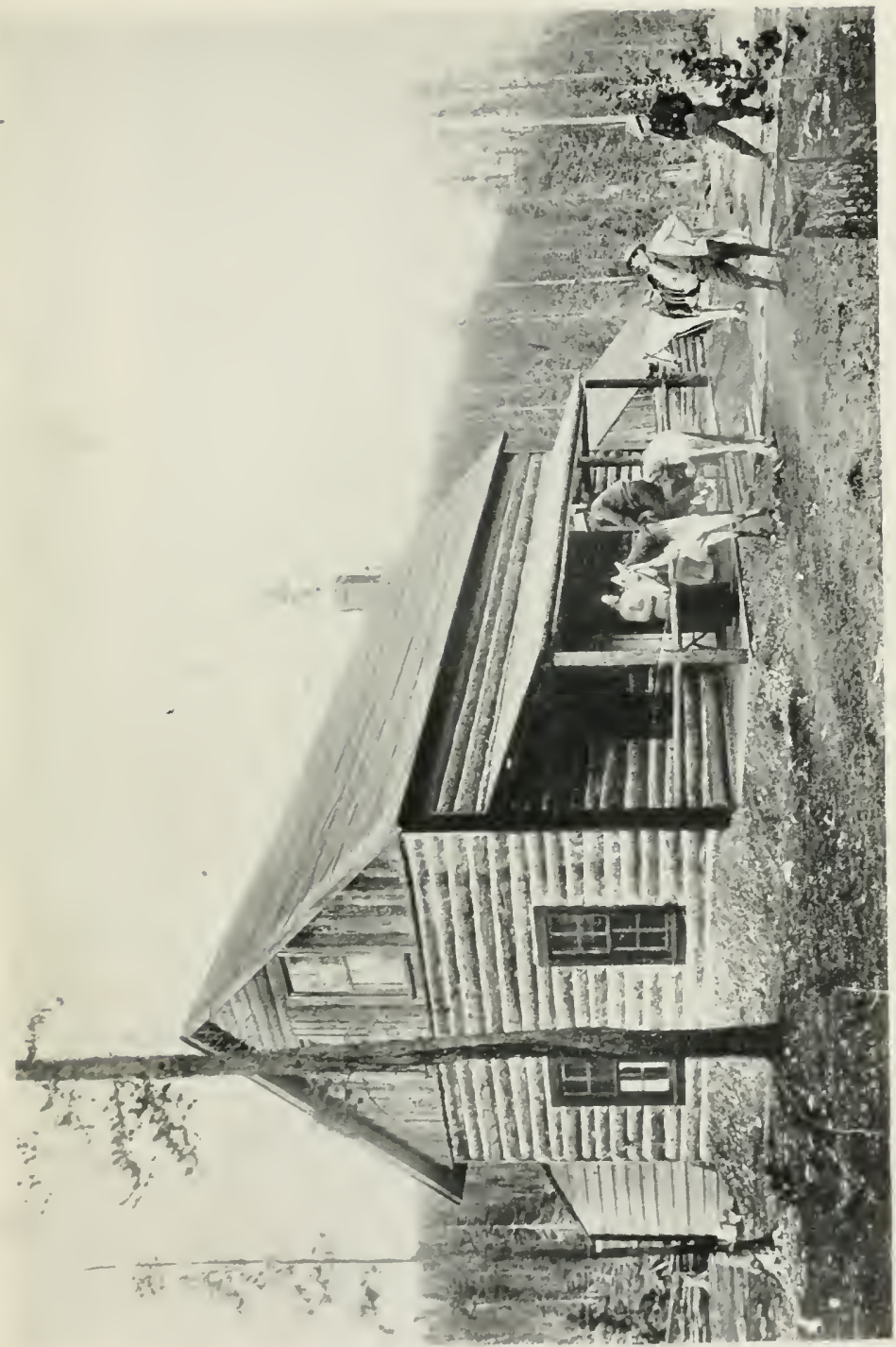



California launches are operated by the Forest Service on Lake Tahoe to patrol the region around the lake for forest fires. Ferries, boats, and launches belonging to private companies or individuals are used by agreement or if necessary are bought by the Service from the Improvement funds. Speeders, motor cars, and hand cars on railroads or logging roads are often used when an agreement has been made with the company. In this way railroads are made a part of the transportation system of the Forest.

Communication Facilities. The system of communication on the National Forests is scarcely less important than the system of transportation. This system includes telephone lines, signal systems, and mail service. The telephone system, as can be readily seen, is of the utmost importance for the transaction of all kinds of National Forest business. In case a Forest Ranger wishes to speak to his Supervisor about controlling a large fire, it makes a great difference whether he can talk to him over the telephone or whether he must send a messenger on horseback perhaps 60 or 70 miles. In the former case practically no time is lost, in the latter it would take at least two days for the 
messenger to reach the Forest Ranger, and in the meantime the fire would continue to rage and spread.

In the absence of a telephone system a signal system is used. The one probably used the most in forest fire protection work is the heliograph, by which code messages are sent from one point to another by means of a series of light flashes on a mirror. The light of the sun is used and the flashes are made by the opening and closing of a shutter in front of the mirror. Very often these heliograph stations are located on mountain tops in the midst of extremely inaccessible country. Where there are a number of these stations at least one is connected by telephone to the Forest Supervisor's office. When the Forest officer at the telephone gets a heliograph message about a certain fire he immediately telephones the news directly to the Forest Ranger in whose district the fire is located, or if he does not happen to be in direct communication with the Forest Ranger he notifies the Forest Supervisor, who then notifies the officer concerned. Of course it is all prearranged who should be notified in case a fire is reported to the heliograph man.

Unfortunately it has been found that this system 


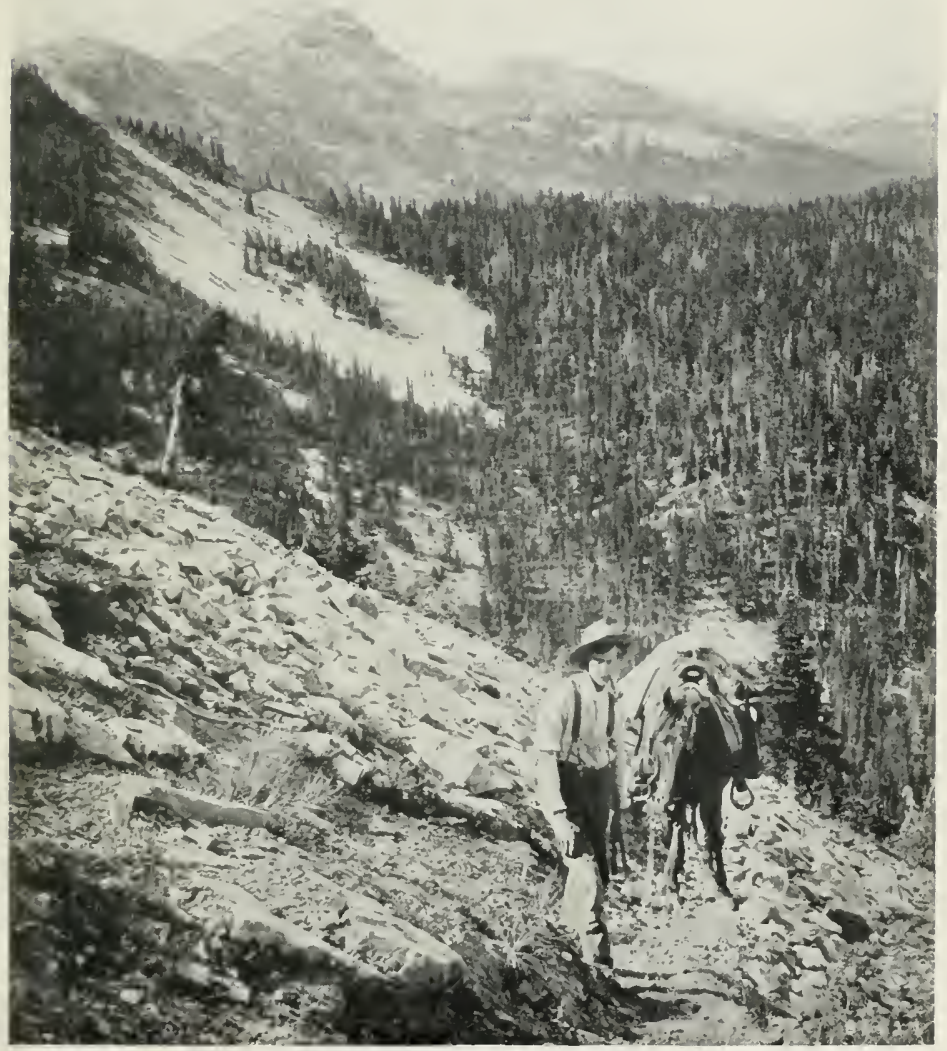

Figure 1.5. I typical view of the National Forest country in Montana. Forest Service trail up Squaw Peak Patrol Station, Cahinet National Forest. 

of communication is not satisfactory even under favorable conditions. 'This system depends upon direct sunlight; without it is useless. When there is much smoke in the air it is also of uncertain value. The heliograph system has perhaps reached its greatest development upon the California $\mathrm{Na}$ tional Forest, but even here experience has shown that it is only a temporary makeshift and the plan is to replace it by a telephone system as soon as possible.

The Forest Supervisor, especially in his summer headquarters, depends directly upon the mail service for communication with the District Forester and the outside world. In many cases the fact that the Forest Supervisor has his headquarters in a small mountain community in the summer has made it possible for that community to receive a daily mail service or mail at least three times a week. When the Forest Supervisor becomes satisfied that mail service is desirable in certain mountain communities he investigates local settlers' needs for mail facilities; or he may coöperate with the people in the nearest village who are petitioning for mail service. Often his influence proves the deciding factor in getting it. 
As I have said before, telephone communication is indispensable to fire protection and to quick and efficient methods of conducting National Forest business. Not only do Forest Service lines enter into the National Forest telephone system but all private lines are also made use of. By coöperative agreements with private companies the National Forest lines are used by private companies, in return for which private lines are used by the Forest Service. In this way a complete network of telephone lines is established connecting not only the Forest Supervisor with all his Rangers and his forest fire lookout stations, but also connecting each one of these with local communities and the large towns at a distance. Thus, when a forest fire occurs and the available local help is not sufficient to control the fire the telephone system is put to use to call help from the nearest villages and towns.

Grazing Improvements. It is often necessary for the complete and economical use of the forage on a National Forest to coöperate with the local stockmen to develop range by constructing improvements. Water may have to be developed; fences, corrals, bridges, trails, and other works may have to be constructed. Often cattle belonging to 

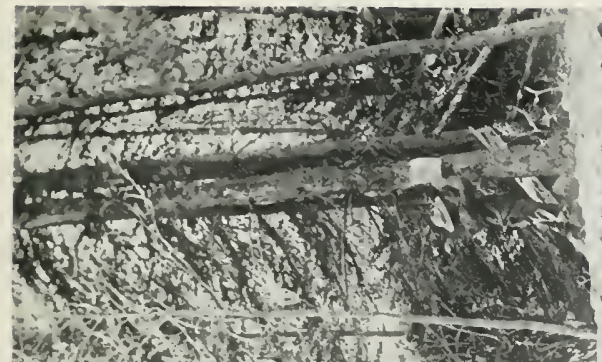

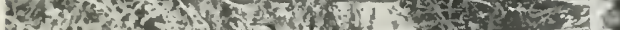

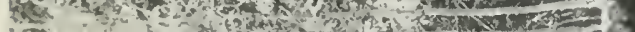

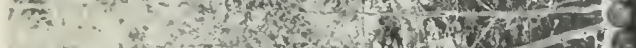
\%

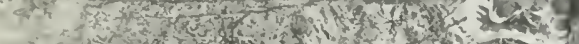

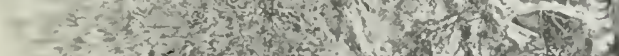

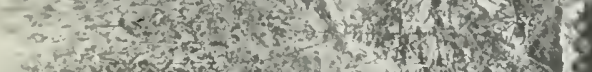

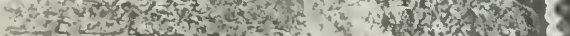

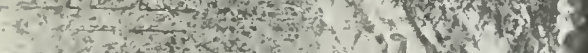

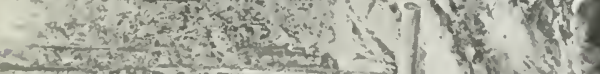

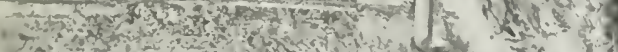

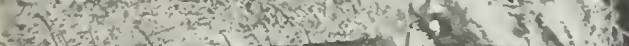

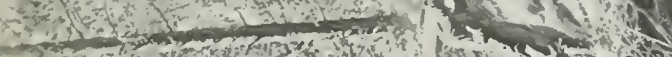

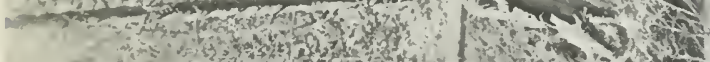

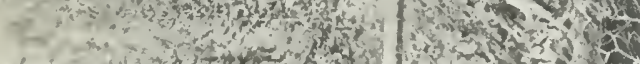
L.

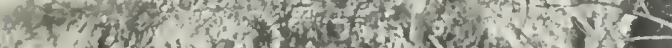

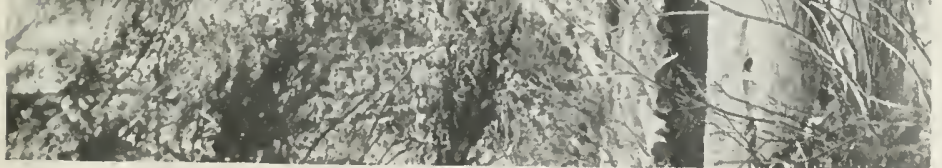

छ

iᄂ

c

¿ุo

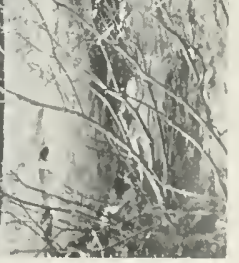



different stockmen are grazed on adjacent areas which are not separated by natural boundaries such as rivers, ridges, or swamps. If there is no obstacle to prevent the cattle from drifting from one range into another, a drift fence is built, thus definitely separating one stockman's range from the other. Often good range would remain unused on account of lack of water altogether or on account of lack of water during the dry season only. In this case the Forest Service usually coöperates with the stockmen to provide water. Roads, trails, and bridges are often necessary to enable sheep and cattle to reach range lands.

Protective Improvements. Ranger stations, cabins, lookout stations, firebreaks and similar works are required to protect the forests from fire and are known as protective improvements. Buildings are constructed for the field force to afford necessary shelter and to furnish an office for the efficient transaction of business. Land is often cultivated for the production of forage crops and fences are built to insure necessary pasturage for live stock used by the Forest officers in their work. The buildings may be substantial houses to be used throughout the year or they may be merely such 
structures as will afford the necessary shelter and domestic conveniences for Forest officers in the summer. 'These summer camps are constructed where needed for the use of patrolmen, officers engaged in timber sale work or at such points as will serve the needs of officers traveling through the forest. Barns, sheds, and other small structures are constructed at the Ranger's headquarters when they are needed. Office buildings are also constructed for the use of Forest Rangers or for summer headquarters of the Forest Supervisor.

Appropriations for Improvement Work. The money for the construction of National Forest improvements is secured from various sources. The annual Forest Service appropriation usually carries a considerable sum for this purpose. In the fiscal year $1918 \$ 450,000$ has been appropriated for this work, which divided among the 147 National Forests gives an average only of about $\$ 3,000$ per Forest. This is really a very small sum considering the size of the average National Forest. Fortunately there are other appropriations and funds and each year sees more money available for this most important work. Under the law 25 per cent. of the 

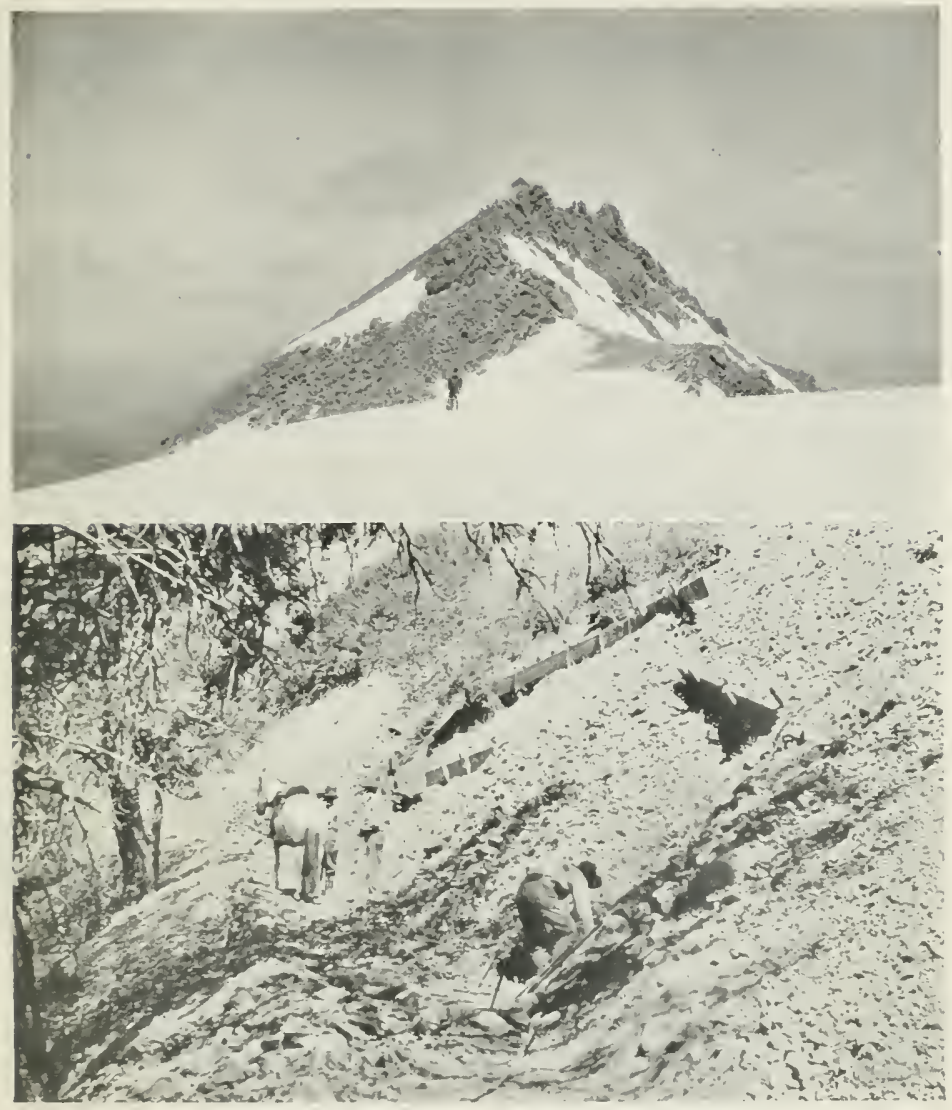

Figure 1\%. I forest fire lookont station on the top of Lassen Peak. elevation 10,100 feet, Lassen National Forest, California. This rahin was first erected eomplete in a carpenter's shop in Red Bluff, ahout jo miles awar. It was then taken to pieces and packed to the foot of I.assen Peak. On the last two miles of its journey it was packed piece hr piece on forest officers hacks and finally reassemblect on the topmost pinnacle of the mountain. Photo hy the author.

Figure 1s. Forest officers and laborers builelingr a wagon road through trap rock. Parette National Forest. Idalo. 

receipts are paid to the States in which the National Forests are located to be expended for roads and schools. The amount to be paid to the States in this way from the receipts in 1917 is about \$848,874.00. By the acts of Congress organizing them as States, Arizona and New Mexico also receive for their schools funds an additional share of the receipts based on the proportion that their school lands within the National Forests bear to the total National Forest area in the States. The approximate amounts due on account of the receipts for 1917 are $\$ 42,844.80$ to Arizona and $\$ 18,687.56$ to New Mexico. Congress has also provided that 10 per cent.- of the receipts shall be set aside as an appropriation to be used under the direction of the Secretary of Agriculture for road and trail building in National Forests in coöperation with state authorities or otherwise. The amount thus appropriated on account of the fiscal year 1917 receipts is $\$ 339,549.61$. This added to the amount carried over from the 1916 receipts fund, $\$ 136,981.23$, and the amount appropriated for improvements, in the regular Agricultural Appropriation Bill, \$450,000.00 , brings the total available for the construc- 
tion of roads, trails, cabins, bridges, telephone lines, etc., on the National Forests for the fiscal year 1918 to $\$ 926,530.84$.

'There is still another fund recently appropriated which will enable roads and trails to be built on a very much larger scale than hitherto has been possible and will result in the rapid opening of forest regions at present practically inaccessible. The Federal Aid Road Act, passed by Congress in 1916, appropriated ten million dollars for the construction and maintenance of roads and trails within or partly within National Forests. This money becomes available at the rate of a million dollars a year until 1927. In general, the States and counties are required to furnish coöperation in an amount at least equal to 50 per cent. of the estimated cost of the surveys and construction of projects approved by the Secretary of Agriculture. The apportionment among the States is based on the area of National Forest lands in each State and the estimated value of the timber and forage resources which the Forests contain.

The total amount from all sources available for roads, trails, and other improvements on the $\mathrm{Na}$ - 
tional Forests during the fiscal year 1918 is therefore $\$ 1,926,530.84$.

THE CLASSIFICATION AND CONSOLIDATION OF NATIONAL FOREST LANDS

The classitication and consolidation of National Forest lands is a matter of great importance to their proper administration and protection. If all the lands within the Forests are to be put to their highest use for the permanent good of the whole people the lands inside of their boundaries must be classified and permanent boundaries established for each Forest. Through this kind of work the National Forests gain in stability. The classification and segregation of the agricultural lands is most important, for these lands are open to entry under the Forest Homestead Act.

Land Classification. The land classification work is organized in the Washington and District Offices under the Branch of Lands. Crews of men are sent out from the District Offices and the work of classification, carefully planned ahead, is done by projects, that is, large contiguous areas are examined together. For instance, the Hat Creek Proj- 
ect on the Lassen National Forest consisted of a number of large areas containing scattered parcels of agricultural lands along the Hat Creek valley in that Forest. For the classification of the lands on a big project a surveyor and a lineman, one or more timber cruisers, and an expert from the $\mathrm{Bu}$ reau of Soils constitute the crew. As a result of this work over 1,100 individual tracts within the Forests were made available for entry under the Forest Homestead Act during the fiscal year 1916, because this land was found to have a greater value for growing agricultural crops than for growing timber. Under this same policy since 1912 about $12,000,000$ acres were eliminated from the Forests, partly because they were of greater value for agricultural use, or because they were not suited for the purposes for which the National Forests were created. Up to June $30,1917,127,156,610$ acres of National Forest land have been examined and classified. Such work as this, once and for all time, will settle the controversy now and then waged in Congress by certain Congressmen that the National Forests have large and valuable tracts of agricultural lands locked up within their boundaries and therefore should be abolished, or turned over to the 
States, or equally radical disposition made of them. Such Congressmen usually are working for some predatory private interests who want to secure the great wealth in the National Forests that is being wisely conserved for the people.

The Consolidation of National Forest Lands. There has also been a great need for consolidating the National Forest lands where these were interspersed with private or state lands. Congress has recognized this need and from time to time has granted authority to exchange lands with private owners or States where such an exchange would be advantageous to the Government through the resulting consolidation of holdings. Thus by getting the government lands into a more compact body their administration and protection are materially facilitated in many ways.

Before any exchange is made it must be ascertained that the land which the Government is to receive has equal value with that relinquished, also that the land is chiefly valuable for the production of timber and the protection of stream flow. Recent additions to the Whitman National Forest in Oregon consisted of privately owned cut-over timherland rapidly reproducing to valuable timber 
trees. Title to this will be secured by exchange for government owned lands.

HOW YOUNG FORESTS ARE PLANTED TO REPLACE THOSE DESTROYED BY FIRE

Reforestation and the Timber Supply. More than 15,000,000 acres of National Forest lands which are capable of producing timber and valuable chiefly for that purpose have been denuded of their original tree growth. These lands are not adapted to agriculture and possess but a small value for grazing. In their present condition they are practically unproductive barrens.

It is probable that one-half of this area will reforest itself naturally through the reseeding of burns, and the encroachment of tree growth upon natural openings, parks, grass lands, and brush lands. This natural extension of the forest on such areas is progressing at the estimated rate of 150,000 acres annually. The remaining half of the denuded area, 7,500,000 acres, must be reforested by artificial means. This land is unquestionably adapted to growing timber and useful to the nation primarily for that purpose. Every year that it lies idle the country suffers a great financial loss, for 
such an immense area is capable of growing at least three-quarters of a billion feet of timber annually. It was recently estimated that the timberlands on the National Forests are producing between five and six billion feet of lumber annually by growth. The complete restocking of the areas now denuded or sparsely timbered will increase the annual production of wood at least 25 per cent., an item certainly worth considering.

Reforestation and Water Supply. Even more important than the value of the timber which is lost annually is the part which these large areas play in the conservation of water supply. Most of this area is on the watersheds of western streams and rivers and the fact that it is denuded is a dangerous menace to the equable flow of the rivers which drain those areas. The National Forests contain over 1,175 watersheds which supply many municipalities, 324 water-power projects, and 1,266 irrigation projects, aside from many other outside power and irrigation projects which are fed by watersheds within the Forests. The cities of Salt Lake City, Utah; Denver and Colorado Springs, Colorado; Portland, Oregon, and Seattle, Washington, all derive their municipal water supply from streams aris- 
ing in the National Forests. The proposed water system for the city of San Francisco, California, is also to be taken from the National Forest streams. A few years ago planting was undertaken on the watershed of the Colorado Springs, Colorado, reservoir. This water supply is worth annually from $\$ 80,000$ to $\$ 100,000$. Besides this the 2,000 horsepower hydro-electric plants are valued at $\$ 40,000$ and the 40,000 undeveloped horsepower are said to have an additional value of $\$ 400,000$, making the total value of the watershed more than $\$ 500,000$, with the probability that a greater water supply having a far greater value will be needed as the city grows.

And there are many evidences that the people of the West have begun to realize that the National Forests are the key to the entire water-supply situation in the West no matter for what purpose the water is used. The public consideration now being given to flood control, the requests from many western cities for special measures to protect their municipal water supply, the concern expressed by irrigation associations in Colorado and elsewhere, lest even the regulated cutting on the National Forests 


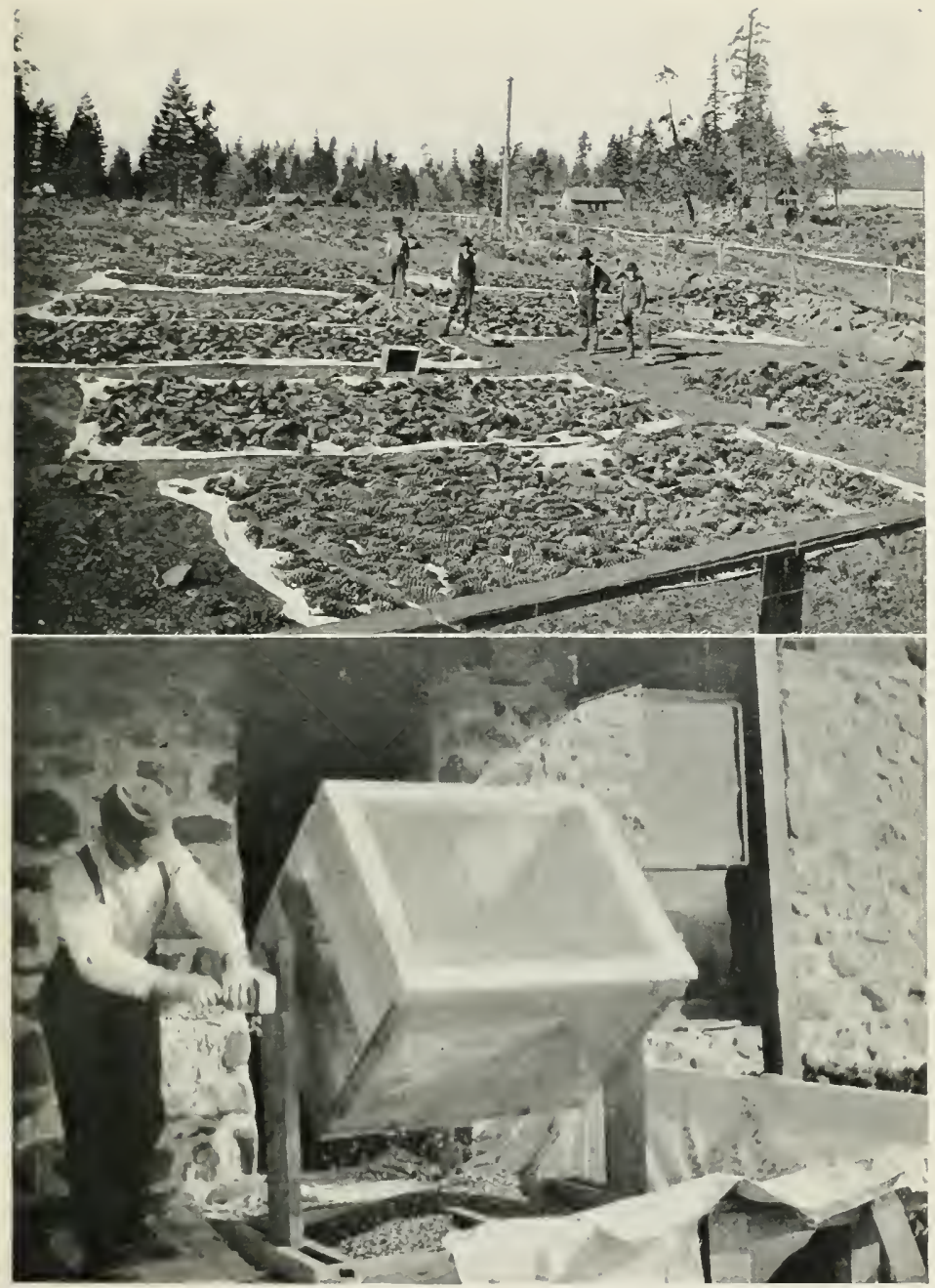

Figure 19. Irying pine cones preparatory to extracting the seed. Vear Plumas National Forest, California.

Figure 20. Extracting tree seed from the cones. The dried cones are shaken around until the seeds drop out through the wire mesh which forms the sides of the machine. 

may reduce stream flow, and the rapid rate at which unused reservoir and power sites in the Forests are being developed, all are evidences of the importance of Forests in protecting water supplies. Reforestation is essential so that the National Forests can effectively discharge this function.

Government Reforestation Policy. The duty of the Forest Service to put the denuded areas which will not be reforested naturally into a condition of productivity admits of no further argument. But the problem is not so easily solved as it is made clear. Under the semi-arid conditions prevailing on many National Forests this work involves uncertainties and unsolved problems. On the $\mathrm{Na}$ tional Forests artificial reforestation was an untried field when the Forest Service entered it. The Government therefore had to develop its own practice in the face of a great variety of conditions, largely unfavorable. The situation still calls for intensive experiments to develop the best methods from the standpoint of both cost and results. More than that, it calls for a different set of methods for each forest region of the West which has its peculiar trees, climate, and soils. Then, lastly, when the 
proper methods have been demonstrated by experiment, the new methods can be applied on a large scale with a very good chance for success.

Therefore intensive experiments must come first. Business prudence requires the development of all methods in detail and reasonable certainty as to their results before large sums are expended upon field operations. In the least favorable regions like the semi-arid mesas of the Southwest, the work is restricted for the present to small, carefully conducted experiments, the result sought being reliable information upon how to proceed rather than the reforestation of many acres. In the most favorable regions, as the western slopes of the Rocky Mountains and the Cascade Ranges, the results already obtained have been so excellent, due to an unusual combination of good growing conditions, that operations upon a larger scale have been justified simultaneously with continued intensive investigations. As the work is extended into each new region or new National Forest, the most favorable sites are always chosen first. After the possibilities and limitations of each method have been ascertained by experience under the best conditions of each locality the work can either be intelligently 


\section{ADMINISTRATION}

extended or restricted. But the work is always conducted from the standpoint of the maximum return for each dollar expended.

In accordance with the policy outlined by the Forest Service watersheds used for municipal supply or irrigation continue to receive first consideration. Large sums are not, however, being spent on such watersheds where any uncertainty as to the outcome exists; that is before successful methods have been perfected by experiment. In addition to watersheds, reforestation work is being conducted for the primary object of producing timber only where climatic conditions and other factors are extremely favorable. As far as possible these areas are being selected with reference to the low cost of the work, natural conditions which insure rapid tree growth, and urgent local need for additional timber supplies. These favorable conditions generally obtain in Washington, Oregon, Idaho, Montana, Minnesota, and Michigan and it is in these States that the best results have been obtained. In California, Utah, Nevada, Colorado, and the Southwest the work is restricted to intensive experiments on a small scale, until sucessful methods of meeting the adverse local conditions have been perfected. 
Methods of Reforestation. 'Two general methods of reforestation have been developed. The first is called the direct seeding method, in which tree seed is sown upon the ground with or without simple forms of cultivation. The other method is the planting method by which seedlings are grown in nurseries under ideal conditions of soil, light, and moisture until they are large enough to be transplanted and stand the rigors of the open field. Direct seeding, where successful, is the cheaper method, but is necessarily limited to sites whose soil and moisture conditions are exceptionally favorable to tree growth. The inability of the newly germinated seedling to establish itself except in comparatively moist soil makes the success of this method on the semi-arid mesas of the Southwest, for example, very problematical, especially since these localities are subject to long dry seasons. In such localities the use of the direct seeding method must be restricted to experiments designed to determine the exact range of conditions under which it is feasible. The main effort, however, of the Forest Service has been given to direct seeding on areas where reasonable success appears to be assured. 


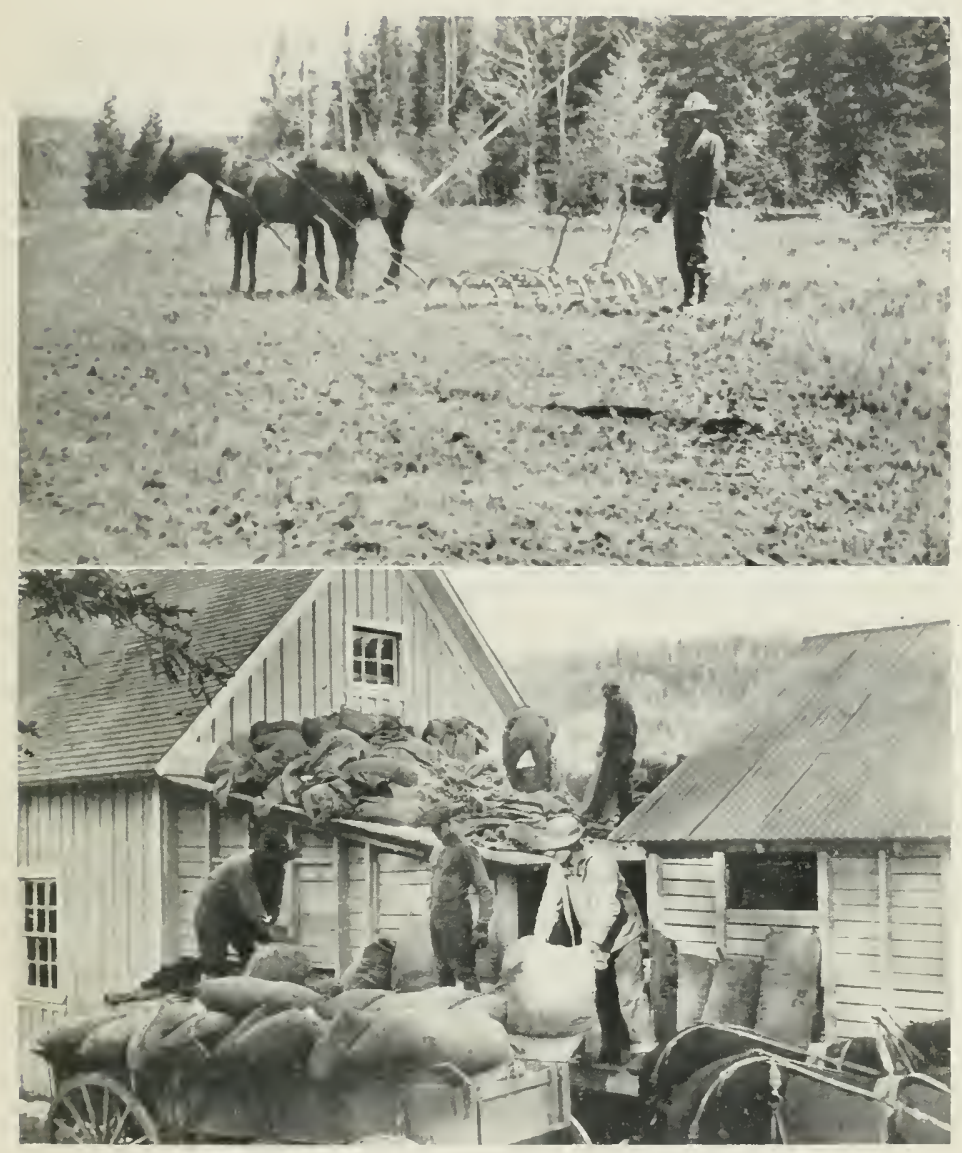

Figure 21. Preparing the ground with a spring-tooth harrow for the broadcast sowing of tree seeds. Battlement National Forest, Colorado. This view was taken at approximately 10,000 feet elevation. Photo by the author.

Figure 22. A local settler delivering a load of Lodgepole pine cenes at the seed extractory, for which loe receives is cents per husbel. Forest officers receiving them. Arapaho National Forest, Colorado. 

The planting of $\mathbf{2}$ or $\mathbf{3}$ year old seedlings or transplants largely overcomes the adverse soil and moisture factors which appear to have made direct seeding unsuccessful in many localities. This method, which is the general practice in European forestry, must without doubt be employed to reforest a considerable portion of the denuded lands. The growing and planting of nursery stock is carried on simultaneously with direct seeding. The object of this is to ascertain the comparative results of the two methods, the sites on which the greater success will be obtained from each, and the proper relation of the two methods in the future development of reforestation .work.

Since reforestation work was begun on the $\mathrm{Na}$ tional Forests about 135,500 acres have been sowed or planted. The larger part of this acreage was reforested by direct seeding. Until only a few years ago larger areas were direct seeded each year than were planted to nursery stock, but at the pres. ent time more planting is being done. During the fiscal year 1916 about 7,600 acres were planted and about 2,800 acres were seeded. The average cost in that year of planting was about $\$ 10.00$ per acre, 
that of the seeding was about $\$ 4.50$ per acre. The 1917 costs were slightly higher, due to the increased cost of labor and supplies.

The reforesting methods of the Forest Service mean the collection of large quantities of seeds and the growing of large quantities of small trees for planting. Since 1911 the Forest Service has collected over 175,000 pounds of seeds for its direct seeding and planting work. During the fiscal year 1916 the Forest Service had 14 large tree-nurseries and 7 small ones, which had in them over 37 million young trees which would, in a short time, be planted in the field. From these figures it is readily seen that the reforestation work on the National Forests is conducted on a large scale.

Direct Seeding Work on the National Forests. The direct seeding work on the National Forests involves many more problems than one would at first thought suppose. Seed must be collected and extracted; it must be stored, if it is not used immediately; if the seed is sown it must be protected from rodents and very often the ground must be prepared before the seed is sown.

Seeds are collected in various ways. Often cones are purchased at advertised rates from per- 

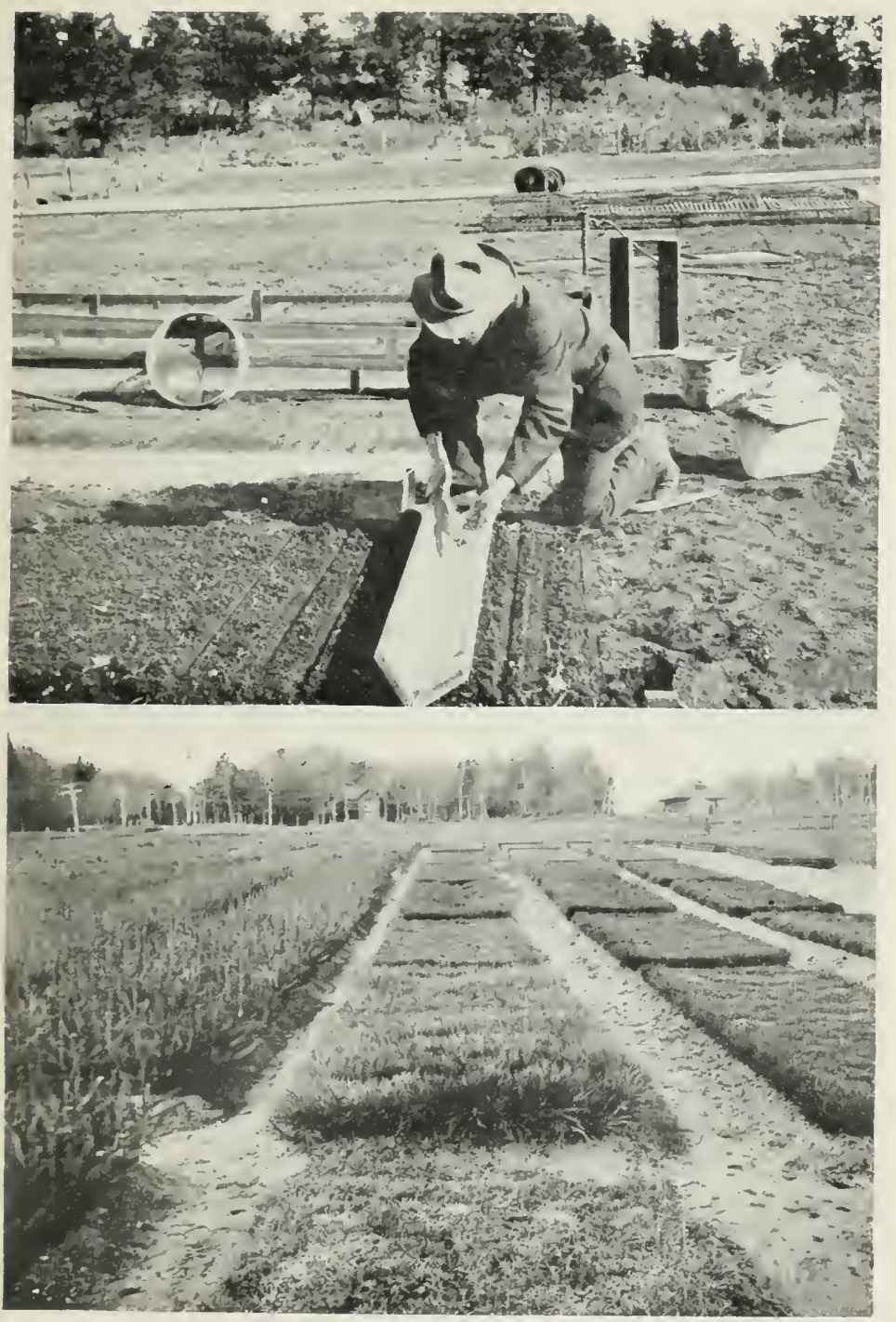

Figure 2:3. In the forest nursery a trough is often used for sowing seerl in drills. The seed scattered along the sides of the trough rattles into position at the bottom and is more eren than when distributed by the ordinary worker at the bottom of the trougl. Pike Tational Forest, Colorado.

Figure 24. Uncle Sam grows the little trees by the millions. These will soon cover some of the bare hillsides on the National Forests of the West. 
sons who make a business of seed collecting. The collectors deliver the cones to a specified Ranger station or to some seed extracting plant. But such collectors are not always available. Seed is collected by Forest officers by stripping cones directly from standing trees or from those felled in logging operations. Large quantities are also gathered from the vast stores or caches assembled by squirrels.

Seed extraction is usually done most economcally by experienced Forest officers. It requires drying by exposure to natural or artificial heat to open the cones; threshing to separate the seed from the scales and woody portions of the cone; and cleaning or fanning to remove chaff and dirt. Much of the extraction has hitherto been done in small quantities at a large number of stations and with very simple home-made appliances. In view of the large amount of seed which must be handled each year the cost of extraction has been materially reduced and seed of higher average fertility has been obtained by concentrating the major part of the work at central seed-extracting plants equipped with improved machinery.

A problem of great importance from the stand- 
point of final results is that of having seed available at the season of the year when it is needed. Past experiments have shown that fall sowing is essential to success in most parts of the West where extensive seeding projects will be conducted. Experience has also shown that seed on a large scale cannot be extracted in time for use in the same season. Moreover, every year is not a good seed year, so that Forest officers must take advantage of the good years to collect large quantities and store them for use during years of seed shortage. Purchased domestic or foreign seed cannot be used to advantage to make up these deficiencies because it is sometimes of poor quality and not adapted to the climatic conditions in which it must be sown. For these reasons methods had to be devised for storing large quantities of seeds for several years at a time and in such a manner that their vitality would not be impaired. Many storage tests have been made by the Forest Service to determine the best way of storing seeds. The tests showed that the sealed glass jar is the best container and that seed must be stored either in air-tight receptacles or at low temperatures to be kept for any considerable period without loss of fertility. 


\section{ADMINISTRATION}

Probably the greatest obstacle encountered in reforestation by direct seeding is the destruction of the seeds by rodents. The failure of many direct seeding projects has been due primarily to loss from this cause. Failure has occurred on areas of practically every character regardless of the time of the year the seed was sown. Success has been encountered only where recent burns had largely eliminated the animals either by outright destruction or by the loss of food supply. The rodents which are most destructive to tree seeds are the ground squirrels, the chipmunks, the mice, and the gophers. It is not strange that they should seek out the seed that has been carefully sown by the Forest officers. In many cases these seeds are their natural food and they are wonderfully diligent and expert in searching it out.

In coöperation with the Biological Survey, the Forest Service has worked on the problem of destroying the rodents. Many methods have been tried out in the field. The free use of grain poisoned with strychnine has thus far produced the best results and has reduced the loss from rodents sufficiently to secure satisfactory germination. The successful elimination of such injury appears 
to lie in the thorough poisoning by this method of areas to be seeded, once or oftener in advance of sowing.

With successful germination assured by the collection of good seed and the protection of it after it has been sowed from rodents, the next problem lies in cheap methods of cultivation and sowing. This will enable the young seedling to develop its root system early enough and rapidly enough to withstand the first annual drought, the dominant feature of the climate of all the western National Forests.

There are numerous methods used in sowing tree seed on the National Forests. Three general methods are used in most of the work. Broadcast sowing is practiced in the fall and spring or upon the snow in the winter, both on ground that has not been prepared and on soil that has been scarified by rough brush drags, harrowing, disking, or partial or complete plowing. In seed-spot sowing the seed is planted at regular intervals in small spots where the soil is cleared of vegetation and worked up loose to a depth of from 5 to 6 inches. When corn planting or dibbling is practiced the seed is thrust into the soil by a hand corn-planter, 

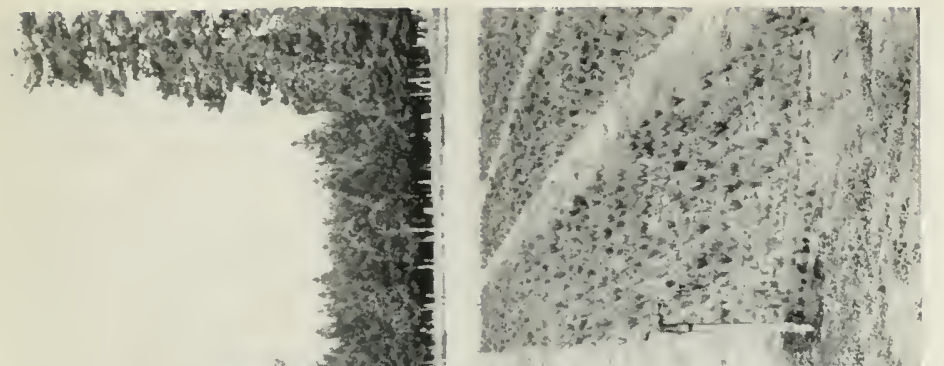

2
0
0
0
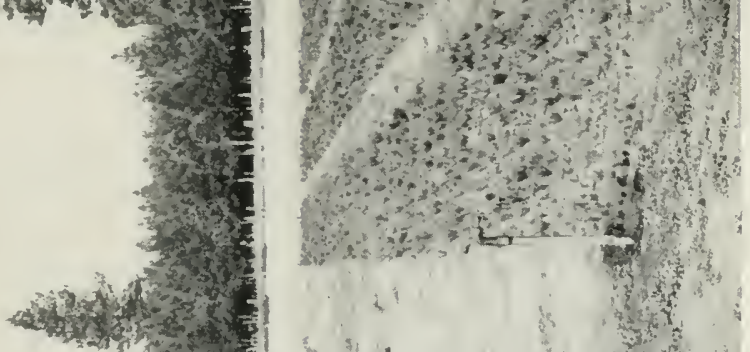

tis

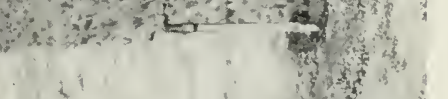

至

들

幽茎
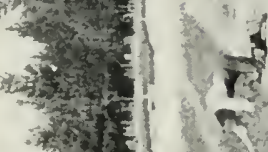

thit

$\left\{\begin{array}{l}3,1 \\ x+3\end{array}\right.$

ing

$\pm \%$

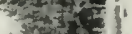

* s

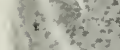

$-x^{2}+x^{2}+1$

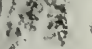

Non 3 .

$4 x^{2}=2$

$-1+x^{2}$

Non eses

$32,+7+5$

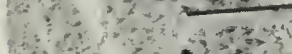

$x+2 a$

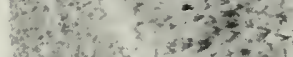

axily

(a) 40

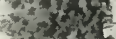

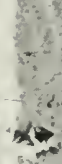

to

-

,

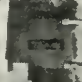

(1)

$x^{3}+4,3=0$

f) 1,0
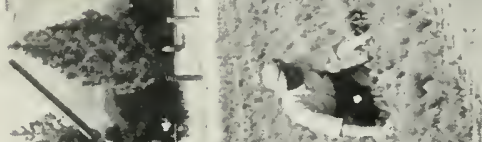

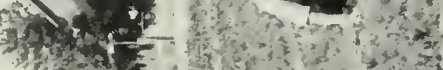

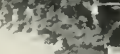

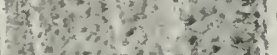

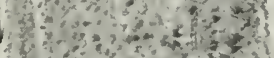

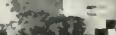

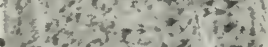

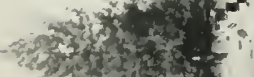

$4 x_{x \rightarrow 1} x$

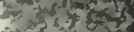

$3,2=0$

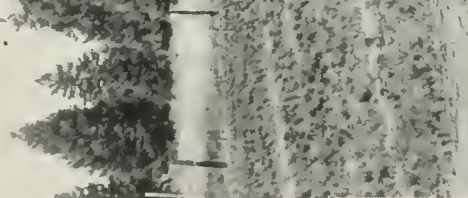
with

if $f^{3}>t=0$

$\therefore=3 y+3=\frac{3}{4}$ \&

$\div \frac{1}{5}$

:

$\Xi$

$\stackrel{\Xi}{\Xi}$

政

$+$

ن

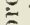

近的

就

즈

충

$\cong \Xi$

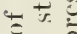

$\Xi$



䒕

은

$\therefore$

$\bar{z} \bar{z}$

$=$

$-\underline{\Xi}$ 



\section{ADMINISTRATION}

or, in the case of large nuts, pressed into holes made with a pointed stick. The corn-planter method is often combined with the preparation of seed spots or the plowing of single furrows, in order to plant the seed in loose soil free from vegetation.

On a large majority of the Forests broadcast seeding on unprepared ground has not succeeded. As a rule satisfactory stands have been secured from broadcasting only after an expensive preliminary cultivation which would be impracticable in extended operations and which would exceed the cost of planting with nursery stock. But broadcasting on prepared strips and upon recent burns has given some success. 'The seed-spot method has been most successful if done at the proper season. Late summer and early fall sowing has produced better results than sowing in spring or winter. As a whole direct seeding has not succeeded, especially when the results and costs of the work are compared with the planting of nursery stock. Planting has thus far yielded better results, especially on the less favorable areas. Furthermore, from the standpoint of final results attained, plantng has actually been cheaper than seeding, in spite of the greater initial cost of planting. While the 
major emphasis in reforestation work is placed upon planting, considerable seeding is being done, but it is confined to the most favorable localities and sites.

Planting on the National Forests. Reforestation by planting young trees has received much attention during the last few years principally because it has produced better results. Much still remains to be said for both methods and future experiments alone can decide which method to use in a specified region and under given conditions of climate and soil. Usually direct seeding has been tried first in any given locality where reforestation work was to be done. In fact the policy of the Forest Service in artificial reforestation on the National Forests has been, first, to conduct experiments to find out what can be done and what is the best way to do it; second, to reforest by direct seeding wherever this is feasible; and third, to plant nursery seedlings where direct seeding has been found too uncertain.

In selecting areas for planting, preference is usually given to the watersheds of streams important for irrigation and municipal water supply and to land which is capable of producing heavy 

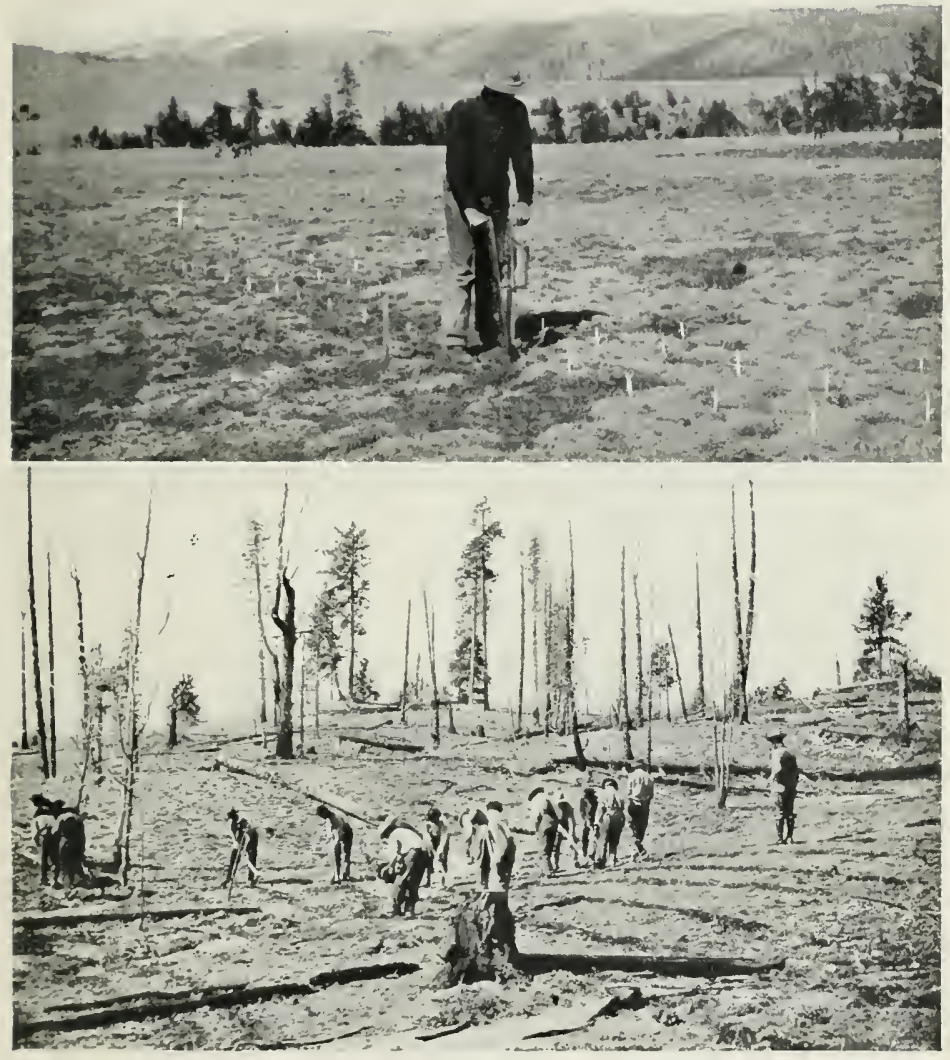

Figure 26. $\Lambda$ view of seed sowing with a corn planter. San Isabel National Forest, Colorado

Figure 2\%. Sowing seed along contour lines on the slopes. Pike National Forest, Colorado 

stands of a quick-growing species or of a specially valuable species. Next in importance are areas which offer good opportunities for object lessons to the public in the practice of forestry. Some areas offer combinations of advantages. For instance, a burned-over tract may be suitable for planting to some rapid-growing species which is also valuable for timber and at the same time may be situated so that it will serve as an object lesson also. It is on such areas in general that reforestation by planting is being concentrated.

While the reforestation of the watersheds of streams important for irrigation and municipal water supply has a large financial value, this value is hard to estimate because it involves not actual cash profit but loss prevented. But when a favorable site is planted to a quick-growing, valuable, species, it is comparatively easy to arrive at a fair estimate of the possible profit on money invested. It has been estimated that under many conditions it is highly profitable to reforest waste lands on the National Forests by planting. From certain experiments made it is estimated that a white pine forest artificially established on a second-class forest soil in Minnesota, will yield about 46,500 board feet 
per acre in 50 years, worth at least $\$ 10$ per thousand feet, or $\$ 465$ per acre. Figuring the cost of planting and the cost of care and protection per acre per year at 3 per cent. compound interest gives a total cost of $\$ 34.07$ per acre at the time the timber is cut and a net profit of $\$ 8.62$ per acre per year. Douglas fir in the Nortliwest will produce 81,000 board feet in 80 years, worth at least $\$ 8.50$ per thousand feet. After deducting all expenses this would leave a net profit of $\$ 555.30$ in 80 years or about $\$ 6.94$ per acre per year. These profits are indeed large, considering that the land is not capable of producing cereal or vegetable crops profitably. And it must be remembered that in all the above calculations all the money invested is earning 3 per cent. compound interest and that the net profits are the earnings in excess of this 3 per cent. interest.

The little trees that are set out on the National Forests every year are produced in large nurseries, where they are grown by the millions. In these nurseries the little trees receive the most expert care from the time the seeds germinate until the time they are large enough to withstand the rigors of wind and weather on the barren hillsides of Uncle 


\section{ADMINISTRATION}

Sam's Forests. The seeds are first carefully sown in seed beds and left to develop in these from one to three years. At the end of one year they may be transplanted in nursery rows where they will have more room to develop. Rapidly growing species like yellow pine are kept only a year in the seed bed and perhaps one or two years in the transplant beds; but slow growing species, like cedar, must remain in the seed beds two years and usually two years in the transplant beds. All this depends upon the species and the site upon which it is to be planted.

If my reader were to visit the Pikes Peak region during spring or fall he would doubtless encounter large gangs of men planting young trees on the barren mountain slopes. Under the proper supervision of Forest officers some of the men will be seen digging holes with a mattock while others are coming directly behind them with bags or boxes with wet moss or burlap, containing small trees. These men are called respectively the diggers and planters. Two men will plant from 500 to 1,000 trees a day, depending upon how deep the holes must be dug to accommodate the roots, whether the ground is bare or covered with sod, whether the land 
is mountainous or level, and many other factors.

In this way Uncle Sam plants his denuded areas in the Forests, so that they will be producing timber for future generations instead of useless brush or tree weeds. The great variety of climatic and topographic conditions included in the National Forest area makes the problem of tree planting infinitely complex. Nursery stock must be raised in each region having similar climatic conditions, and in each of these regions different methods of planting must be used, depending upon local conditions. The semi-arid mesas of Arizona and New Mexico present different planting problems from the humid forest regions of Oregon and Washington; the methods used in the sandhills of Nebraska and the sand plains of Michigan cannot be applied in full on the high mountain slopes of Colorado; nor are the planting problems in the vast chaparral areas of northern California anything like those encountered in the mountains of Idaho, or in the prairie States of the Middle West, or in the Black Hills. Then, again, the reforestation problems of the chaparral fields of southern California are more perplexing than any I have mentioned above. 


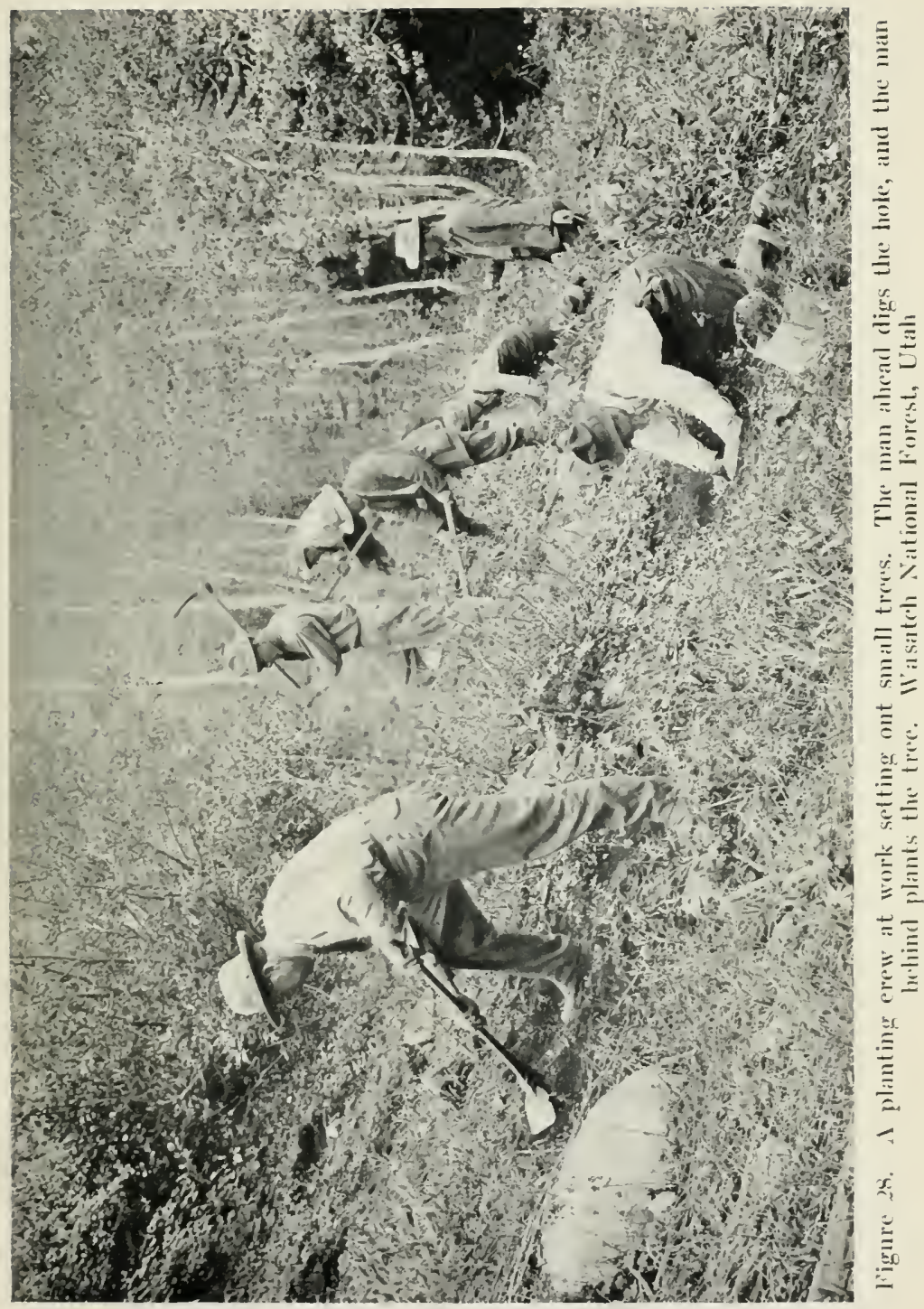





\section{ADMINISTRATION}

THE ORGANIZATION AND SCOPE OF FOREST EXPERIMENTS AND INVESTIGATIONS

The Need of Scientific Experiments. No science can make progress without intensive experiments and investigations, least of all a new science like forestry. The science of forestry as it has but the science of forestry as applied to American conditions is still in the infancy of its development - probably not over 20 years old. Therefore we know very little about our trees, our forests, and the wood which they produce, and the professional foresters who handle the scientific work on our National Forests are very much handicapped. To supply the needed information about the requiretheir wood can be put, and many other related subjects, the Forest Service has established 8 Forest Experiment Stations (recently reduced to 6) and one Forest Products Laboratory. It has become the business of these institutions to study the laws governing the life of the tree and the forest and their effect upon the final product-wood. The 
the many problems which confront the Forest officers in the management and the protection of the National Forests; while the Forest Products Laboratory was organized to promote the most profitable utilization and the most economical disposition of the forest products of the National Forests. Both sets of institutions, in doing this, are helping materially to build up the science of American Forestry, which even to-day can hardly be said to exist.

The Science of Growing Timber. In order to better understand the many diversified problems which are being studied at the Forest Experiment Stations, it is necessary to give the reader a few ideas concerning the science of forest ecology. This science is the basis of all problems dealing with the growing of timber and is therefore a study of the utmost importance to forestry. Forest ecology is the study of the relations of trees and forests to their surroundings. By surroundings (or environment) we mean all the factors which influence their growth and reproduction, such as soil temperature, soil moisture, soil texture, rainfall, light, wind, air temperature, relative humidity, altitude, slope, exposure, and surface. Forests, we must remember, are not warehouses of standing logs; they are not 


\section{ADMINISTRATION}

merely aggregations of individual trees; but they are complex communities of living organisms, which are affected in many ways by climate and soil and which, in turn, affect in no small degree the climatic and soil conditions in their immediate vicinity. 'The forester cannot treat the forest as an aggregation of individuals, for forests have laws which govern their behavior which are entirely different from those that govern the individual tree. Some foresters and botanists prefer to call this science by the name of "tree sociology," and they compare it with human sociology. Individuals, as we well know, are governed by different natural laws than communities. Just so with trees and forests. In order, therefore, to grow a never-failing supply of timber intelligently and economically we must understand these complex organisms and communities, we must study their behavior under different soil and climatic conditions and ascertain the conditions under which they grow best. Only by doing this can the forester achieve all the objects of forestry, namely, to help Nature to produce more and better timber, in a shorter length of time and at the smallest possible cost.

The experimental work of the Forest Experi- 
ment Stations is grouped under such categories as these: dendrological studies, forestation studies, studies in forest influences, studies relating to forest managemerit, studies in forest protection, commercial tree studies, and grazing studies.

\section{Dendrological Studies. Dendrological studies} include studies in tree distribution and wood identification. For each tree species growing in the United States (and there are about 500 of them) it is desirable to know its geographical distribution, its commercial distribution, and its local distribution. The first of these deals with the entire range of the tree by geographical divisions; the second of these with the distribution of those bodies of timber that are of commercial quantity or size; and the last deals with the distribution of the tree by local divisions, such as lowlands, slopes, ridges, valleys, plateaus, etc. This information is usually placed on maps for permanent record. Observations by Forest officers on the many National Forests are recorded by them and at the first opportunity sent to Washington. Very often it happens that the range of a species of tree is considerably extended and that a tree is found growing in a locality where it was never reported from before. The identifica- 
tion of woods is done at the Forest Products Laboratory. The distinguishing characteristics of the woods of many American tree species have been determined. The wood of different trees is studied under the microscope to discover in what way it differs from other woods closely related. Many such results are published for the benefit of both the lumber dealer and the general public in the form of bulletins. Both the subject of dyewoods and that of the many woods now sold as mahogany have been investigated in this way. The resulting data have been used by many companies and have helped to protect the public from frauds.

Seed Studies. Experiments in reforestation are grouped under seed studies, nursery studies, and sowing and planting. Considerable work has been done in developing the best methods of seedextraction. Much valuable information has been gathered on the largest amount of seed that may be extracted from pine cones of different species per unit of time at different degrees of temperature; the maximum temperature which may be applied to seeds of different species without impairing their vitality; the germinating power of seed extracted at different temperatures; the comparative length of 
time required for the germination of seed extracted with or without artificial heat; and the most economical type of seed-extracting plant. Studies have been made upon the comparative germination of tree seeds in the field and the greenhouse. The ultimate success of the plantations being established on the National Forests in a large degree depends upon the character of the seed used. Hence studies are being conducted of the effect of altitude, soil, age of the tree, density of stand, insect damage and disease infection, and other factors that affect the mother tree, upon the character of the seed collected from those trees, and the growth and form of the resulting seedling. Also tests to show the effect of the source of seed on the form and growth of young seedlings have indicated very clearly that with all species the seed grown in the locality where the trees are to be planted give as a rule better results than seed imported from another region.

Nursery Studies. Nursery studies endeavor to show the most efficient methods for growing young trees for field planting for each species of trees. It is of great importance to know how much seed to sow per foot in the nursery beds; what is the best time (spring or fall) for sowing; to what depth the 
seed should be covered in order to give the highest germination; whether better results are obtained by drill sowing or by broadcast sowing; the best methods of shading, fertilizing, watering, and cultivating the seed beds; the methods of securing the best root development of the young seedlings; the best time and method of transplanting from the nursery beds to the transplant beds; the best methods for retarding spring growth in seedlings to be used at high altitudes; and other problems of similar nature.

Forestation Experiments. Experiments in forestation have, year after year, proven that planting is much safer than direct seeding and ultimately less expensive. For this reason a greater emphasis has been placed upon planting studies. These studies have attempted to show the best season for planting each species; the best methods of planting; the most advantageous classes of stock to use; and what the most suitable sites are for each species of tree.

Studies of Forest Influences. Studies on the influence of forests upon stream flow and erosion are attempting to furnish important data for American conditions upon this subject. At the Wagon Wheel Gap Forest Experiment Station in Colorado 
such a study is being carried on. The purpose of the study for the first two or three years has been to determine the character of the two streams which are to be measured. The forest cover on the two watersheds is practically identical. The results so far obtained indicate that the influence upon the stream flow must be about the same in both cases, and, consequently, a comparison of these streams after the denudation of one watershed will be a very fair test of the influence of the forest cover upon the relative height of the flood stage and lowwater stage, the amount of erosion, and the rate of melting of the snow.

Experimental observations which have been conducted since 1908 at the various Forest Experiment Stations have shown that the forest exercises a decided moderating influence upon temperature extremes, wind motion, and evaporation. Likewise, the presence of a forest cover retards the melting of snow in the spring, and in this way huge snowbanks in the forests feed the nearby streams until late in the summer. Forests therefore have been shown to conserve the water supply and also causing this water to run off slowly rather than in sudden floods. Studies have also been conducted on determining 


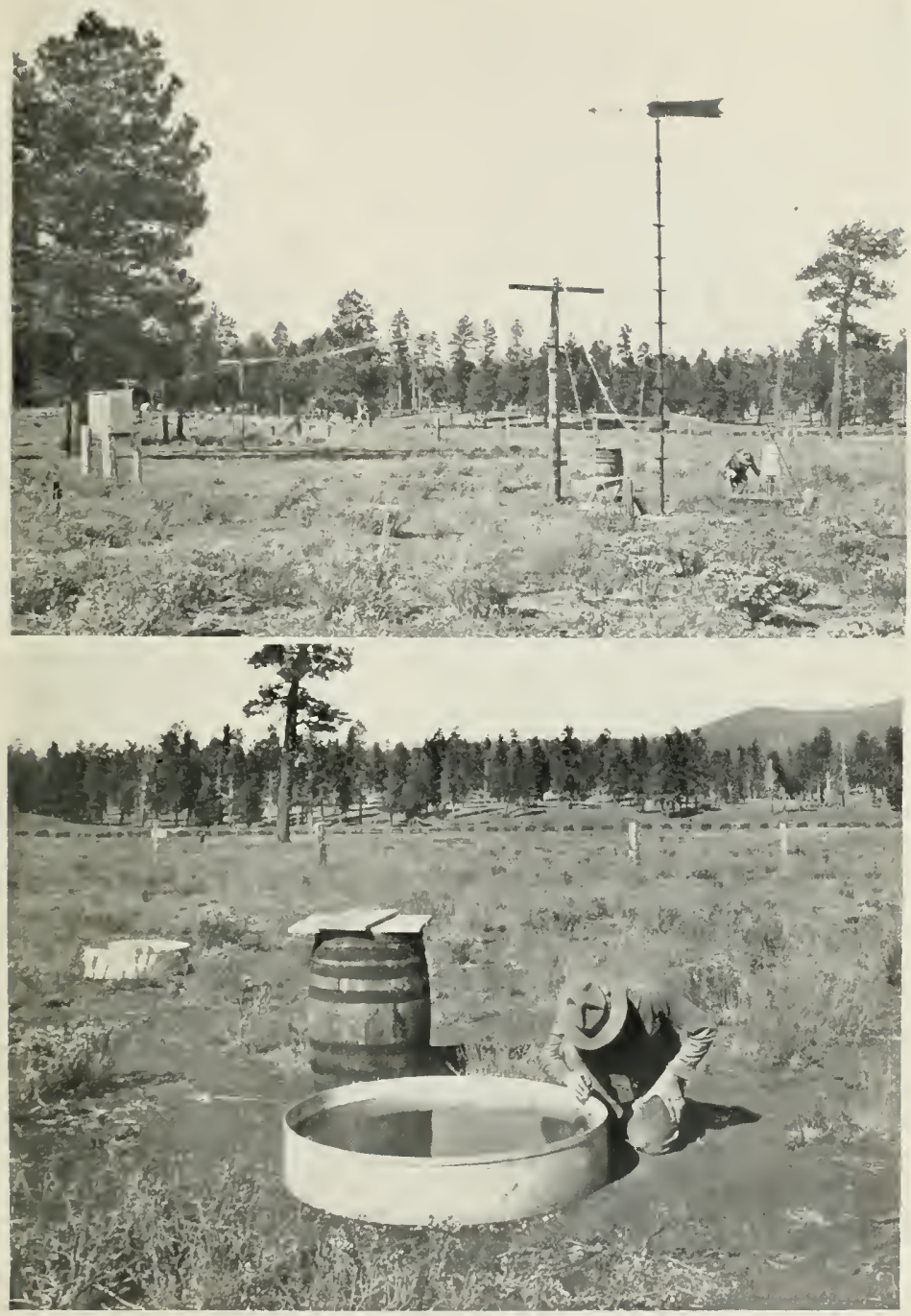

Figure 29. At the Fort Valley Forest Experiment Station, Co conino National Forest, Arizona. A typical meteorological station Forest officer measuring precipitation. Note the shelter which contains thermometers and also the electrically equipped instruments to record the direction and velncity of the wind.

Figure 30. Forest officer ascertaining the amount of evaporation from a free water surface. Fort Valley Forest Experiment Station, Flagstaff, Arizona. 

the effect of cutting timber upon the climate within the forest.

Meteorological Observations. The climatic requirements of forest types have been studied at the Fremont Experiment Station since January 1, 1910, through experimental observations, and other stations have taken up the same problem since that date. The first step in this work at the Fremont has been to obtain a complete meteorological record as a basis for determining what climatic conditions are most important in limiting the natural range of such important species as Yellow pine, Douglas fir, and Engelmann spruce. The data collected so far have shown that soil moisture and soil temperature are the controlling factors in determining the existence of the three forest types. It has also been shown what climatic conditions each of the three types of forest must have in order to succeed. This work has since been extended to include other types of forest and a meteorological station has been established at timber line on Pikes Peak. This station, which is at approximately 11,500 feet, is equipped with self-recording instruments to measure the climatic factors which obtain at that elevation and which mark the uppermost 
altitudinal limit of tree growth in that locality.

Such studies as these, based upon systematic meteorological observations, have an important bearing on all other forest problems. The data secured in this way especially assist the technical foresters in solving the various problems in forest management, reforestation, fire protection, and land classification, besides giving positive knowledge of the environment in which our trees live and of the factors affecting their growth and reproduction. These systematic observations are of prime importance if we ever hope to have a science of American Forestry.

Forest Management Studies. Experiments in forest management are carried on to determine the best methods of cutting National Forest timber to secure natural reproduction and at the same time to improve the quality and productivity of the remaining stand. These studies are carried on by means of permanent sample plots, on which all the trees are carefully measured and recorded. First the timber is cut on the plots under different systems of management, or thinnings or improvement cuttings are made. An exact record is kept of the amount of timber removed and of the size and dis- 
tribution of the remaining trees. Measurements taken at regular intervals show the precise effect of the method used on each plot. Close observations of the reproduction which takes place, brush and other forms of cover which may establish themselves, and changes in soil conditions are recorded. On similar sample plots methods of brush disposal, methods of marking timber for cutting, and thinning methods are studied. After logging there are several ways in which the resulting slash may be disposed, depending upon surrounding conditions. In some localities the brush must be burned immediately on account of the fire danger which its presence involves; in other places it must be removed because it interferes with reproduction; in still other places the brush may be scattered over the area because there is little fire danger and, in fact, the brush has been found to assist and protect reproduction. All these possibilities must be determined by experiments. Likewise in marking timber for cutting and in thinning practice various methods are possible, depending upon circumstances, the most important of which are the requirements of the species and the density of the forest. 
Other management studies deal with the determination by actual measurement of the volumes of trees and stands, and the growth of trees and the yields of whole forests. Reliable growth and yield data for the different species and types are necessary to properly handle timber sales as well as for forest management. They are also essential for determining damages caused by fires and trespass.

Forest Protection Studies. Studies in forest protection endeavor to find the best methods of protecting the National Forests from fire, grazing, disease, insects, wind, snow, hail, and animals. The most efficient protection of the National Forests from fire calls for an accurate, scientific knowledge of all the factors that enter into the problem. Comprehensive studies are undertaken to secure the basis for a more scientific method of distributing National Forest fire-protecting funds. The aim has been to find the degree of intensiveness in fire protection warranted by timber, forage, and watershed values, as modified by their susceptibility to damage by fire. Under the ideal system of allotting fire-protecting funds, the most valuable resources, which at the same time are most in danger of destruction by fire, should receive the largest 
amount of funds and therefore the greatest amount of protection. Less valuable resources, less susceptible to fire danger, should receive protection in proportion. Other classes of fire protection studies have to do with the various phases of fire prevention, fire detection, and fire control. Studies have also been carried on to determine the rapidity with which fire spreads in different forest types, and under a given set of climatic conditions.

Protection from Grazing Damage. Studies of the effects of grazing upon the natural reproduction of forests are conducted with a view to devising a system of range control which would minimize such injury without requiring the total exclusion of the stock from the range. Studies have shown that serious damage occurs to seedlings under four feet in height during the dry season, on areas containing poor forage, or which have been overgrazed, or where there was little or no underbrush. It was found that sheep do twice as much damage as cattle. Some of the measures that have been adopted to lessen the injury to reproduction by sheep and cattle are: the revegetation of overgrazed areas, reductions in the amount of stock, provisions for the better distribution of stock by 
the regulation of watering places, and the exclusion of sheep from cut-over areas on which reproduction is deficient until the seedlings reach a sufficient height to be out of the reach of the animals.

Protection from Insects and Diseases. In cooperation with the Bureau of Entomology and the Bureau of Plant Industry the Forest Service is conducting a large number of studies and investigations dealing with the insects and diseases that do destructive damage to forests. The direct result of these studies will be the gradual eradication of predaceous insects and dangerous tree diseases from the valuable timber forests of the Government. Control measures already taken have shown the value of exact scientific information. On the Klamath National Forest some years ago about 900 acres were treated for insect infestation. The cost was about $\$ 3,000$ and the amount of timber saved by the eradication of the insects was worth over $\$ 600,000$. Other studies are carried on to identify and describe certain classes of insects, such, for instance, as those that destroy the seeds of trees in the cones. The various families, genera, and species of forest insects are studied and described, and the results are published in the form 
of monographs. Many of these insects are difficult to identify and concerning others very little is known. Investigations on tree diseases have not made such good progress, because tree diseases are much more difficult to control. Tree diseases, like human diseases, must be prevented instead of controlled. A general survey of the tree diseases prevalent in the National Forests has been made, especially in California. Further studies have brought to light little known or even unknown diseases. In California, studies have shown that a certain relation exists between old age and disease. Incense cedar, for example, seems to become infested after it reaches maturity at an age of about 150 years.

Tree Studies. Commercial tree studies are made of important tree species. The results are published in the form of monographs dealing with the range, silvicultural characteristics, growth, yield and management of each tree. These studies bring together all the important facts known about the tree described, such as: the industrial uses of the wood, the conditions under which the tree succeeds, the rate of growth in different situations, and the most suitable methods of management to 
secure the highest returns. Tables are included to show the volume of the trees at different ages and sizes, in cubic feet, in cords, in board feet, etc. Studies are also made of the life history and requirements of important forest trees, often in connection with commercial studies. Such studies cover: local, geographical, and commercial occurrence of the species, the species which are associated with it, the habit of the tree, its soil and climatic requirements for germination and growth, and the various matters connected with its reproduction. Such publications as these give the Forest officers much valuable information about the trees with which they are dealing, and also furnish the only sources of information to students in forest schools on the characteristics and requirements of the trees important in forestry in this country.

Grazing Investigations. Grazing investigations, being intimately connected with a great national industry, have received a considerable amount of attention. These studies are confined at present to grazing reconnoissance, the reseeding of depleted mountain grazing lands, studies in the best methods of handling sheep on the range, studies of the effect of grazing on the forest, iden- 
tification of range plants, and the systematic elimination of poisonous range plants and predatory animals.

Grazing reconnoissance is a stock taking of the forage possibilities of a certain piece of range land. This work is usually done by organized parties, but a small amount is done also by Forest officers in spare time. This study aims to collect all the important grazing information, such as: the area of grazing lands, the kind of forage, the species of forage plants, the location of streams, springs, and other watering places for stock, the location of stock driveways, drift fences, and cabins, the location of timber lands that do and those that do not contain forage, and many other matters pertaining to the grazing of stock. The maps and field data secured furnish the basis for range improvement and more intensive range management. Up to date, over 12,288,885 acres of range lands have been covered in this way.

All intensive forage and range experiments are conducted at the Great Basin Experiment Station on the Manti National Forest. Here intensive problems are carried on under controlled conditions and under constant and careful observation 
and the necessary care and thoroughness is given to them which could only be given then at a lully equipped experiment station. All grazing investigations on the National Forests are carried on under the direct supervision of this station.

The seeding of depleted grazing lands is accomplished either by direct artificial seeding or through rotation grazing. Under the former method the seed of native or foreign grasses and other range plants are sown on the range, in the attempt to increase the forage crop. By rotation grazing, that is, permitting the stock to feed first on one area and then on another, the grasses and forage plants are allowed to recuperate from the effect of grazing and allowed to reproduce. The stock is excluded from one area while the seed is maturing, and after the seed has matured and become scattered on the area the stock is allowed to graze on it. As the stock feeds on the plants it tramples the seed into the ground and thereby furnishes favorable conditions for the germination of the seed. There are few parts of the National Forests that cannot be completely regenerated by the adoption of either one or the other of these two methods. 


\section{ADMINISTRA'TION}

To reduce interference with the natural processes of reforestation, damage to tree growth and watersheds, depletion of grazing lands, and the waste of valuable forest resources, it is important to develop improved methods of managing different kinds of live stock on different types of land. 'These new methods of handling stock have been applied only to sheep. The lambing of sheep in small inclosures on the open range has resulted in the saving of a large percentage of the lambs. The new method of bedding sheep where they happen to be at nightfall has been found to have many advantages over the old system of returning them to an established bedding ground a number of nights in succession. The results have been better sheep, less damage to range, and more feed.

It was not so many years ago that practically nothing was known about the various plants which make up the forage crop on the National Forests. Forest officers could not identify the plants or say whether they were of value for forage or not. This made it difficult to secure the use of each range by the class of stock to which it was best adapted, to apply deferred and rotation grazing and to eliminate losses from poisonous plants. This ob- 
stacle to efficient range management was overcome when a system of plant collection and identification was started by the Forest Service. Some 23,000 specimens of about 3,000 different species have been collected on the National Forests, identified by specialists and the collector informed as to the value of each species. 'The identification of range plants is the first step toward securing an intimate knowledge of the life history of the plant. Such information as the soil and moisture requirements, date of flowering and seeding, requirements for reproduction, and its relation to other range plants is of the utmost importance if the maximum forage crop is to be produced on the range each year. This constitutes the latest stage in the development of grazing studies.

Investigations Dealing with Poisonous Plants and Predatory Animals. In coöperation with the Bureau of Plant Industry the study of poisonous plants and the means for reducing the losses from them has been undertaken. The death camas, the lupines, the larkspurs, some of the wild cherries, locoweed, and practically all species of zygadenus are plants that have been found to cause death among stock. While the handling of stock to 


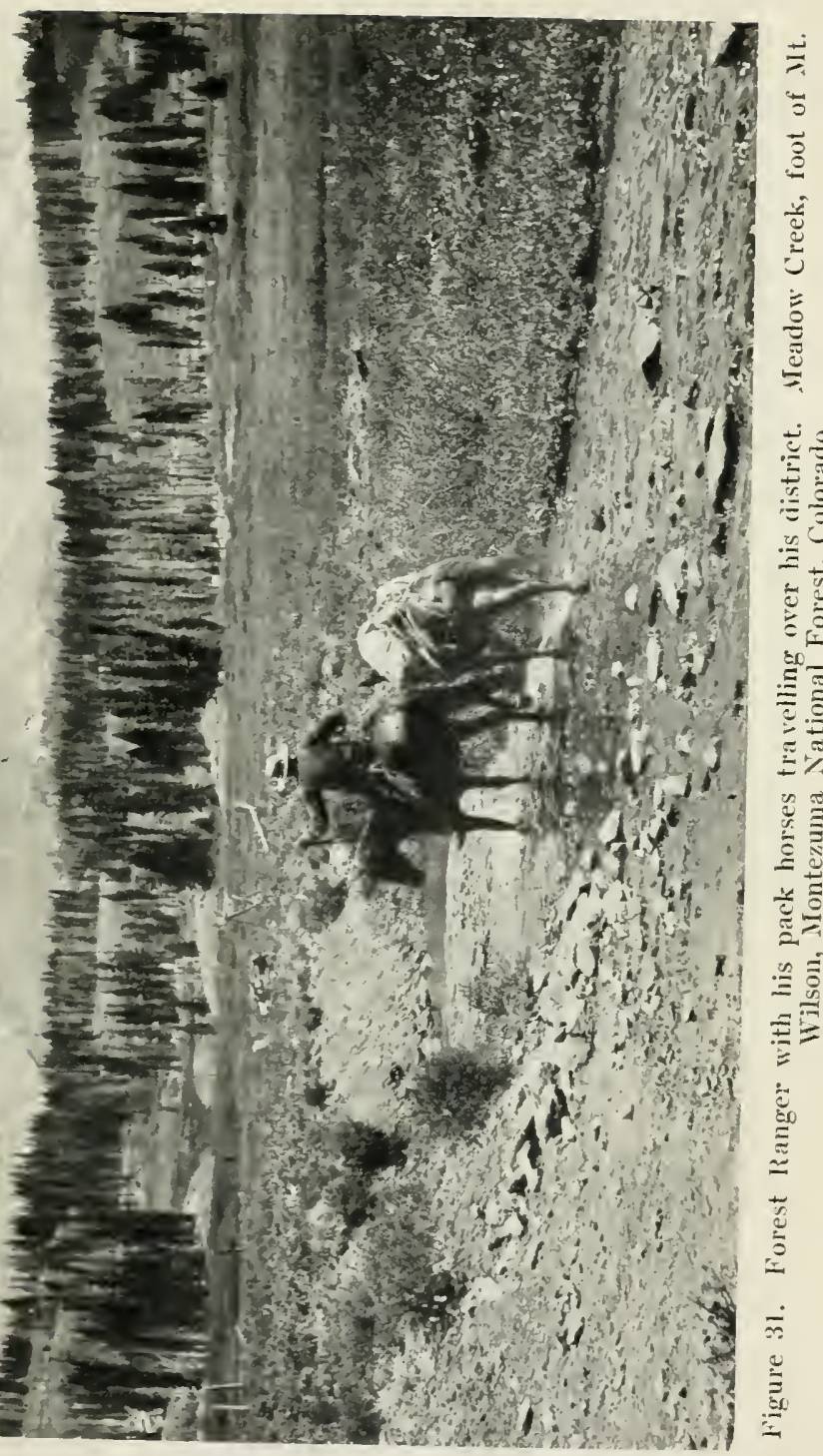





\section{ADMINISTRATION}

avoid the poison areas can eliminate the losses to a small extent, it has been found that the most expeditious remedy is in digging out and destroying the poisonous plants. On the Stanislaus National Forest in California, a cattle range of about 14,000 acres, containing about 67 acres of larkspur, was cleared of this weed at a cost of about $\$ 695$. The ave"age loss of cattle in previous years had been about 34 head. Following the eradication of the larkspur the loss was 4 head. The net saving was valued at $\$ 1,800$. Similar operations are conducted on other Forests.

The work of the destruction of predatory animals has been transferred to the hands of the Bureau of Biological Survey. Formerly special Forest Service hunters were detailed to hunt the animals, and these men used to kill about 4,000 a year. The Biological Survey, however, still furnishes traps, ammunition and poison for the destruction of predatory animals to Forest officers, who do this work in connection with their regular duties. Bears, coyotes, mountain lions, lynxes, wildcats, and wolves are the animals that do the most of the damage. What makes the problem a difficult one is that the wolf and the coyote, the two species 
which do the greatest damage to game and domestic stock, are transient visitors on the Forests which frequent the Forests only when game and stock is most abundant. They are bred, born, and spend the greater portion of their lives in the foothills outside of the National Forests. Under these conditions the animals killed on the Forests are quickly replaced by others from outside. For this reason the matter was handed over to the Biological Survey, which will destroy these animals throughout the public domain and the results will be much more permanent and effective.

Besides the investigations carried on by the Forest Experiment Stations many studies are carried on dealing with forest products. The purpose of the Branch of Forest Research of the Forest Service is to promote the most profitable and economical utilization of forest products by means of experiments and investigations. The work of the Branch falls into three divisions: National Forest utilization, the work of the Forest Products Laboratory, and industrial investigations.

National Forest Utilization Experiments. The work of the proper utilization of the products of the National Forests is under the supervision of 
the District Forester and the Assistant District Forester in charge of Forest Products in the districts. Only three out of the seven districts have such an organization. These men have charge of all problems connected with the use and marketing of National Forest timber, the construction of improvements on the Forests, and related administrative questions. The following problems are included: studies of existing industries, covering methods and costs of manufacture, grades, and other specifications of manufactured products and the prices obtained for such products; the collection of market prices, mill scale studies to determine grades and overrun, and investigations in kiln drying; waste in existing industries and closer utilization possible through improved methods; new uses for National Forest species through wood preservation; introduction of industries which will result in closer or more profitable utilization, as the manufacture of pulp and paper, wood distillation, turpentining, and the manufacture of secondary wood products; overcoming prejudices against particular species or classes of material; general questions of timber supply and demand, markets and freight rates; advice and assistance in the con- 
struction of National Forest improvements, particularly in the use of wood preservatives; advice and assistance to persons on any matter connected with the utilization of National Forest timber; the preparation of publications upon subjects covered by investigations which have practical or scientific value; and demonstrations of methods or processes developed by the Forest Service for the benefit of local communities.

The presence on a Forest of large quantities of unmarketable timber, or dead timber, or of material not used in current sales would mean an investigation of methods for its utilization. Local problems affecting wood-using industries in manufacturing or marketing timber, such as sap stain in lumber, dificulties in seasoning lumber, and the effect of different silvicultural methods upon the average grades of lumber manufactured, are also taken up with the Products experts at the District Office. Also in the construction of National For-. est improvements the Forest Supervisor may need assistance in applying wood preservatives to telephone poles, fence posts, and other material. Sometimes timber treating plants are erected, if necessary, to treat not only material used on the 


\section{ADMINISTRATION}

National Forests, but also material used by local residents near a Forest.

One of the important problems which confronts the Office of Products in the various National Forest districts is the utilization of the so-called low grade or inferior tree species. The terms "high grade" and "low grade" or "inferior," as used at present, merely indicate the lumberman's valuation of the timber from his point of view and according to his standards of value. If a certain species will not produce clear lumber, which is straight-grained, easily worked, and not subject to splitting or warping, it is at once classed as inferior. But the Forest Products specialists each year are making progress in demonstrating that wood, in order to be of marketable value, does not necessarily need to be cut in the form of lumber. It is also being shown that proper methods of drying lumber make possible the use of inferior woods for lumber and manufacturing purposes.

The Office of Forest Products in California has made considerable progress in overcoming the lumberman's prejudices against the inferior species in the California National Forests and the species are beginning to find wider use and to command better 
prices. The discovery that Incense cedar was valuable for making lead pencils caused the price of this so-called "inferior" species to jump from an average of $\$ 10$ per thousand feet in $\operatorname{logs} f$. o. b. cars to as high as $\$ 16$. White fir, a species religiously avoided by lumbermen in the woods, was found to have special properties which make it very valuable as a pulpwood. One mill in California now uses annually upwards of $\mathbf{3 0 , 0 0 0}$ cords of it for making paper. Lodgepole pine has been shown to have a great value for telephone and telegraph poles when treated with preservatives. It was found to be 12 per cent. stronger than Western Red cedar, the standard pole timber, has a more desirable taper and can be shipped for less money. Many other cases could be cited from this and other National Forest Districts.

Forest Products Laboratory Experiments. The work of the Forest Products Laboratory includes investigations on the mechanical properties of wood; the physical and chemical characteristics and properties of wood; air seasoning and artificial drying of wood; agencies destructive to wood; wood preservation; wood distillation; production of naval stores; and the production of pulp and paper and 


\section{ADMINISTRATION}

other chemical products of wood. 'This work is carried on at the Laboratory and sometimes in coöperation with the National Forests and district experts. At the Laboratory there is a director and a large staff of technical and scientific men, such as chemists, physicists, and engineers, each of whom is an expert in his particular line of work.

A good deal of attention is given to testing the strength of woods grown in the United States, as a means of assisting user's to select the species best adapted to a given purpose, or to find substitutes for species which are becoming difficult to obtain. The strength of a good many species used for structural timbers has been tested. The species most used for this class of timber are the Southern pines, Douglas fir, Norway pine, Tamarack, and Red spruce. An important discovery was made several years ago that Western hemlock, generally considered an inferior timber, showed an average strength 88 per cent. as great as that of Douglas fir, one of the best construction timbers in the United States. Strength tests have also been made on fire-killed timber and these have shown that timber killed by fire is almost as strong as green timber. Other tests have been made to de- 
termine the effect of preservative treatment upon the strength of timber. As a result of the large number and variety of strength tests carried on by this Laboratory the United States Government now has a more thorough and comprehensive collection of data on the mechanical properties of wood than any other nation.

Many studies are also conducted to determine the physical properties and the structure of the different kinds of wood grown in this country. The minute structure of the wood of many of our native species has been studied by means of microscopic slides. A study has also been made of a large number of species to determine the specific gravity of the actual wood substance. Other tests are made to determine the specific heat of woods.

The drying or seasoning of woods, more especially of certain species which have been found difficult to season, has received a good deal of attention. A new type of kiln, invented by a Forest Service man, has been devised to season such woods as the eucalyptus, which has always been very difficult to handle in drying. Western larch has been seasoned with a loss of only 5 per cent., whereas the loss in ordinary commercial kilns usually ran be- 
tween 60 and 70 per cent. As a result, many manufacturers have remodeled their old kilns to embody the new Forest Service methods. A new method has also been developed for the rapid drykilning of Eastern hemlock, which has great commercial possibilities.

Experiments in wood preservation have to do with the kind of preservatives it is best to use, the character of the wood to be treated, and the methods of injection. Experiments have developed the best methods for treating railroad ties, mine timbers, fence posts, wood paving blocks, telephone and telegraph poles, and wharf piling. Untreated mine timbers have been found to last only from 1 to 2 years, while treated ones are usually entirely sound at the end of 4 years. Untreated railroad ties last from 5 to 10 years, while treated ones will last over 15. Such experiments as these have shown the advisability of treating all kinds of timbers with creosote or zinc chloride, or some other preservative. Many new preservatives are being proposed or marketed each year by various companies or individuals. These are all tested to determine their value to prevent the growth of fungi in the wood. Their efficiency 
varies greatly and many of them have been shown to have very small value.

Studies in wood distillation seek to find new woods which can be used for this industry, new and more efficient methods which can be employed, and new uses for wood waste and stumps. Charcoal, wood alcohol, acetate of lime, and tar are derived from the distillation of such woods as beech, birch, and maple, to which tar oils and turpentine are added for the pines and other resinous woods. These by-products of wood distillation have many uses, as well as the many products which are, in turn, made from these by-products. Charcoal is used in the manufacture of black powder. acetic acid is used in the manufacture of explosives, and wood alcohol is converted into formaldehyde for disinfection against contagious diseases. By means of temperature control methods developed at the Laboratory in the destructive distillation of hardwoods, the net gain per annum of one company's plant was over $\$ 17,000$. About one-half of the plants of the country have adopted the new method developed by the Forest Products Laboratory.

Experiments have been conducted by the Labor- 
atory in the distillation of the needles of coniferous trees and the distillation of the crude gum of some of the important timber trees of the South and West. The oils distilled from many trees in this way have found great use for various purposes. Shoeblacking owes its peculiar aromatic odor, faintly suggestive of the deep spruce and hemlock woods, to an oil which is distilled from these same kind of needles. Evergreen tree leaf oils are used for the perfume of soap, and in the manufacture of liniments, insecticides, and medicinal preparations.

Investigations have been carried on at the Forest Products Laboratory in making artificial silk from sawdust. The industry has already attained considerable proportions. It consists principally of converting cellulose into viscose, which, in turn, is manufactured into an almost endless number and variety of silk and other goods varying from sausage casings to silk hose and tapestries. Sawdust is used also in the manufacture of inlaid linoleum and dynamite.

Experiments in naval stores are attempting to improve the old methods of harvesting turpentine, which have proven very destructive to the forests. With the approaching exhaustion of the Southern 


\section{OUR NATIONAL FORESTS}

Pinery as a field for the naval stores industry, it has become more and more important to find other species for this purpose. Consequently the Laboratory has conducted experiments with the various pines on the National Forests in California, Colorado, Arizona, and New Mexico.

A great many pulp and paper investigations are also conducted by this Laboratory. The large size of the industry and the threatened exhaustion of the native spruce forests which furnish the principal supply are circumstances which call for intensive investigations. About nine-tenths of the paper which we use is made from wood, and the amount of wood which is converted into paper annually has reached almost 5,000,000 cords. There are over 2,500 newspapers in the United States, and it is said that a single issue of a New York Sunday paper consumes the trees on about 15 acres of forest. The main object of the work at the Laboratory has been to use other species of wood for the manufacture of paper to offset the fast waning supplies of spruce. Poplar, hemlock, pine and balsam are now being used in considerable quantities. News and wrapping paper has also been successfully made from many National Forest 


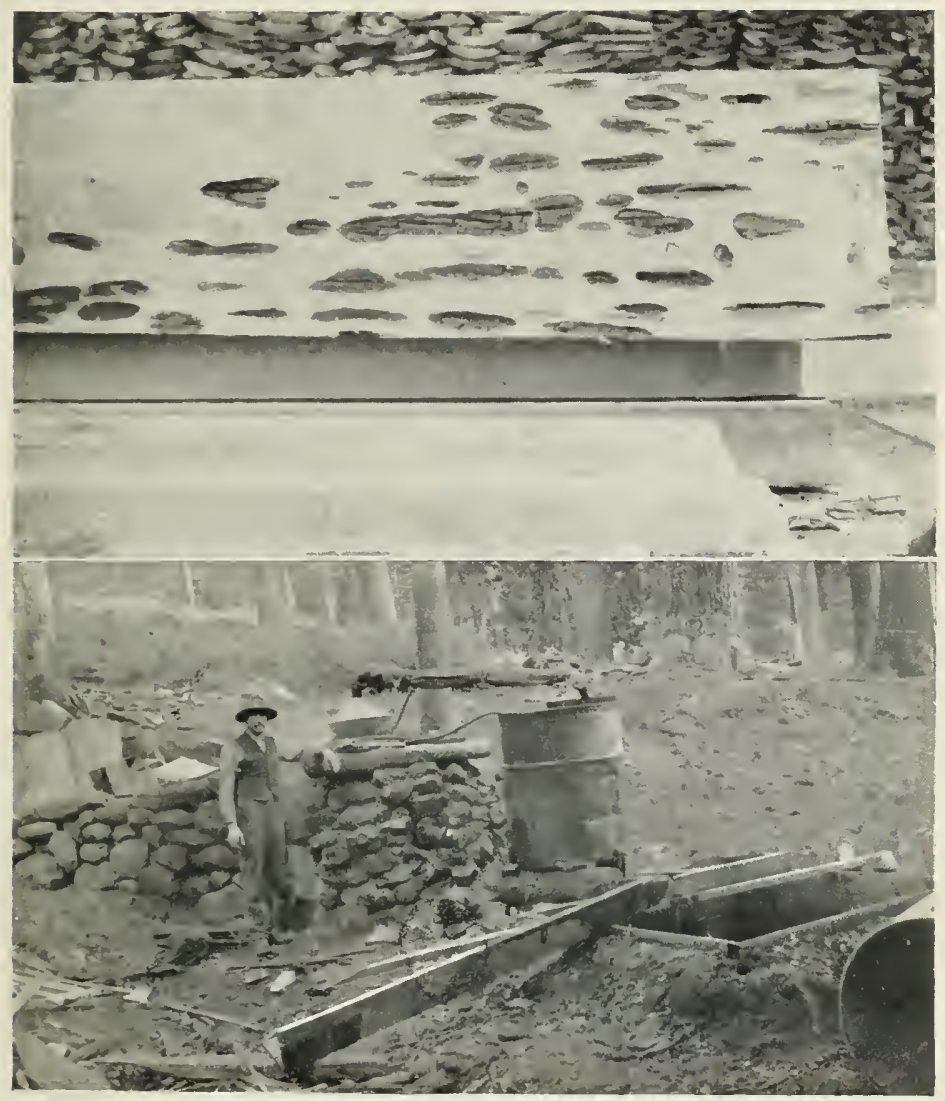

Figure 32. A plank of Incense cedar affected by a disease known as "pin rot." By cutting the cedar timber when it is mature this can be largely aioided. Lassen National Forest, California. Photo by the author.

Figure 33. The western pine forests will some day be a great source for naval stores. By distilling the crude resin of the Jeffrey pine a light volatile oil-abietene-is secured which has great healing and curative properties. Iassen National Forest, California, Photo by the author. 

species, including Sitka spruce, Western hemlock, Engelmann spruce, Red fir, White fir, and Lodgepole pine. Kraft paper has been made and manufactured into suitcases, bags, wall coverings, twine, and similar articles. Not only has the Forest Products Laboratory brought into use species of trees never before tried for paper making, but it has also improved some of the old methods of paper making to such an extent that the results have been adopted by various large paper mills.

Many strength tests are conducted with packing boxes. The railroad companies of the United States are paying annually claims amounting to many millions of dollars because of goods damaged in shipment. Much of the damage is preventable through properly constructed boxes. Tests conducted at the Laboratory have shown for cannedfood boxes an increase in strength of 300 per cent. by the use of four additional nails in each end of the box. The results of these tests are being rapidly adopted by manufacturers and canners.

The dyeing principle of the Osage orange wood was not used prior to the investigations conducted by the Laboratory. The value of this material has been so conclusively shown that about one million 
dollar's' worth of the dye is now being manufactured annually in the United States and practically all from material which was formerly wasted.

The discovery that sodium fluoride is superior to sodium carbonate in preventing sap stain in lumber promises to reduce materially the present estimated loss of $\$ 7,000,000$ from this cause.

Industrial Investigations. The function of the Office of Industrial Investigations of the Branch of Forest Research is to conduct statistical and industrial studies of uses of wood in the United States. The aim of these investigations is to determine methods and conditions under which wood is now used; the marketable products obtained from it; tendencies in methods of manufacture; and improved methods possible, especially in the utilization of waste. When practicable, such investigations are followed by the commercial application of their results. This office also conducts all statistical investigations of the production and use of forest products.

The work of industrial investigations includes the following: collection and compilation of statistics on the production and consumption of forest products, prevailing market and stumpage prices, 
imports and exports, and transportation rates; the compilation and study of specifications of rough and manufactured forest products; studies of lumber manufacture and wood-using industries as to methods, forms of material, waste, costs, equipment, substitution of one species for another, and improvements through a more conservative use of raw material; studies of special problems or features of wood-using industries; advice and assistance to States, industries and individuals along such lines of work; and the dissemination of results by publications.

Many studies in wood utilization are made not only of certain industries like the shingle, or the lumber industry, but also dealing with the industries of particular sections of the country and with the various States. These investigations in the States show the kinds and amounts of woods required by the various industries, the purposes for which the various species are employed, and the extent of their use. So far the wood-using industries of 35 States have been studied and the results published.

Records of lumber prices for important woods are compiled quarterly. These figures are useful 


\section{8}

OUR NATIONAL FORESTS

in establishing timber sale prices on the National Forests. Statistics as to the annual consumption of lumber in the country are also compiled by this office.

The wood waste exchange was established in 1914 by the Forest Service. It consists of two lists of manufacturers, which are sent out quarterly to persons desiring them. One of these is of "Opportunities to Sell Waste" and contains the names of firms which use sawdust and small pieces of wood. This list is sent to people having waste for sale. The other list is of "Opportunities to Buy Waste," and gives the names of concerns which have waste to dispose of. This list is sent to people who wish to buy material. No charge is made for this service, and at the present time over 500 coöperators are using this exchange.

By the use of this exchange, makers of wooden novelties have been successful in finding supplies of material near their plants. Other wood-working industries have been able to dispose of their waste at higher prices than they could otherwise have obtained. Many firms were located within short distances of each other, but until recently have had no way of getting together. A Philadel- 


\section{ADMINISTRATION}

phia firm, engaged in the manufacture of composition flooring, has been able to obtain a portion of its sawdust from a New York lumber company. A New York woodworking establishment disposed of its waste pieces of white oak and sugar maple to a maker of wooden novelties in Connecticut for use in the manufacture of furniture knobs. A clock maker of Connecticut secured waste material for making clock boxes from the planing mill of a New York lumber company. 


\section{CHAPTER III}

\section{THE PRO'TEC'TION OF THE NATIONAL FORESTS}

The resources of the National Forests may be injured or destroyed in many ways. Fire may burn the timber and young growth; insects and tree diseases may damage or kill timber, and certain persons may innocently or willfully commit trespass on National Forest land and use the resources without permit. Then also, the fish and game of the Forests must be protected from unlawful shooting and trapping, and the water issuing from $\mathrm{Na}$ tional Forest streams must be kept free from pollution, to protect the public health.

\section{PROTECTION FROM FIRE}

Forest Fire Danger on the National Forests. Practically all the resources of the National Forests are subject to severe injury or even to entire destruction by fire. It is an ever-present danger on the National Forests, due to their great inacces- 
sibility, their dry climate, and to other unfarorable conditions. 'There are probably few forest regions in the world where the danger of fire is greater than on the National Forests. The great size of the individual Forests, as compared with the size of the available patrolling force, the difficulty of reaching remote areas across miles of wilderness, the dry air and light rainfall in most parts of the western United States, the prevalence of lightning storms in the mountains, the sparseness of the population, and the constant use of fire in the industries and the daily life of the people, all combine to make the hazard exceptional.

Importance of Fire Protection. Forest fires when uncontrolled mean the loss of human lives, the destruction of homes, live stock, forage, timber and watershed cover. Besides the direct damage to the National Forest resources it defeats all attempts to practice forestry; it nullifies all efforts of forest management, such as regulation of cutting to insure a second crop of timber, the planting of denuded areas, and the restriction of grazing to assist reproduction. Fire destroys the very improvements which are constructed annually at great expense. In other words, protection from 
fire is the first and most important problem on the National Forests without which no operation or transaction, however small, can be undertaken.

If the problem of fire protection is the most important task confronting a Forest officer on the National Forests, then certainly fire prevention is next in importance. Obviously it is easier to prevent fires than to fight them. All large conflagrations have their origin in small fires which if they could be reached in time could probably be put out by one man. But in regions remote from water and supplies fires may start and reach vast proportions before a party of fire fighters can get to the scene, no matter how promptly the start is made. By far the best plan, therefore, is to prevent fires rather than to depend upon fighting them after they get started. To this end the Forest Service has given the most earnest consideration. During the dangerous season the main attention of Forest Supervisors and Forest Rangers is devoted to preventing fire. Extra men are employed, the Forests are systematically patrolled, and a careful lookout is maintained from high points. Roads and trails are so built that every part of the Forests may be quickly reached with pack animals. Tools 
and food for fire fighters are stored at convenient places. The Ranger stations and lookout houses are connected with the office of the Forest Supervisor by telephone, so that men may be quickly assembled to fight a dangerous fire which the patrolman cannot subdue alone. Each Forest Supervisor endeavors to secure the coöperation of all forest users in the work of preventing fires and in reporting and helping to fight them in case they get started.

Probably the beginning point of any discussion of forest fires is a consideration of their causes. The Forest Service has kept careful records year after year (by calendar and not fiscal years) concerning the cause, the damage, the area burned over, the cost of fighting and many other matters. During the calendar year 1917 there were 7,814 forest fires on the National Forests. Of these the National Forests of California had to contend with 1,862. Of the total number of forest fires 40 per cent. were confined to less than $1 / 4$ of an acre, 28 per cent. to less than 10 acres, while 32 per cent. spread over areas greater than 10 acres. The large percentage of small fires shows how efficiently the National Forest fire protection organization works 


\section{OUR NATIONAI, FORESTS}

in keeping the area burned over to the lowest possible acreage.

Causes of Forest Fires on the National Forests. Forest fires on the National Forests originate in many different ways. In 191\%, lightning caused 27 per cent.; unknown agencies, 17 per cent.; campers, 17 per cent.; incendiaries, 12 per cent.; railroads, 13 per cent.; brush burning, 7 per cent.; saw mills, 3 per cent., and all other causes, 4 per cent. Thus it will be seen that a very large percentage, at least 60 per cent., of the fires are attributable to human agencies and are therefore preventable. At least 27 per cent. of the fires, those attributed to lightning, are not preventable, and the only way to combat those is for the Forest officer to get to them as soon as possible after they get started. The preventable fires, however, may be arrested at their source, that is, by popular education dealing with the use of fire in the woods these causes can be greatly reduced and, in time, no doubt, eliminated. Therefore, the fire protection problem immediately resolves itself into two almost distinct phases of action-fire prevention and fire control.

Just how these various agencies start fires may be of interest. Railroads cause fires by their loco- 


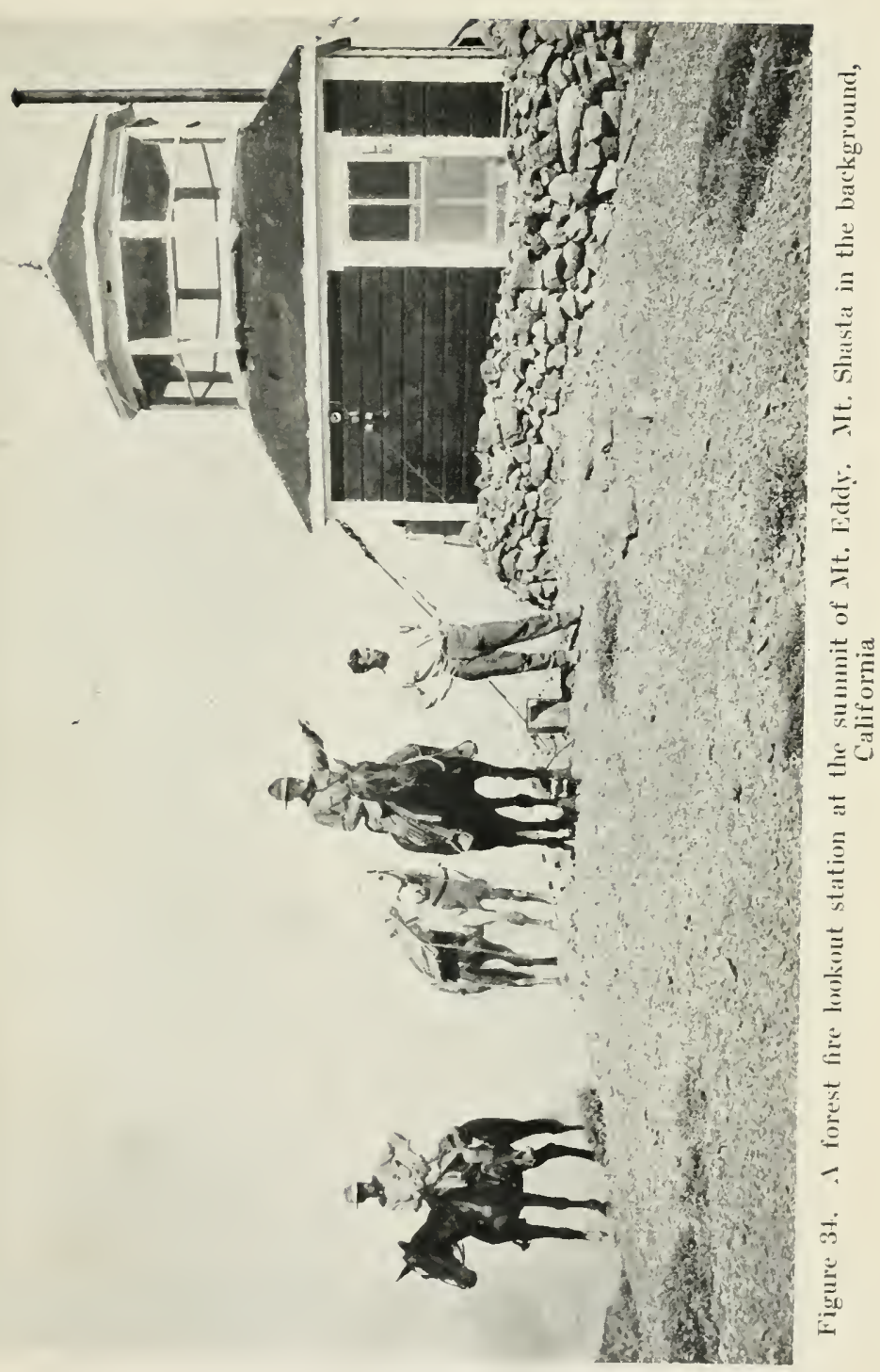



motives sending out sparks through the smokestack or dropping hot ashes along the right-of-way. These sparks alight in inflammable material, such as dry grass and leaves, and start a fire. Lightning sets fire to trees, especially dead and dry ones. In the California mountains, lightning storms without rain are frequent and these do great damage. The author has seen as many as nine forest fires started by a single lightning storm inside of half an hour. Incendiary fires are set by people with varying intent. How many are set with malicious intent, just to see the forests burn, is not known, but many fires are started by people setting fires to drive game, to improve the pasture, to make traveling through the woods easier, or for other reasons. Brush burning includes those fires which start from settlers clearing land and burning the brush and thickets. Campers cause a large percentage of the fires by leaving their camp fires burning. Instead of extinguishing them before they leave camp, careless people let them burn; a wind blows a few sparks into some dry leaves or grass nearby, and the fire is started. Many forest fires also start around logging camps by sparks escaping from logging engines, or by setting fire to 
the slash that is left after logging and allowing these fires to get beyond control.

Behavior of Forest Fires. Fires behave differently, once they get started, depending upon the character of the timber, the amount of wind, and the degree of inflammability of the forest cover. Ground fires burn the inflammable dry grass, needles, dead twigs, etc., on the ground; crown fires are much more severe and, being usually fanned by a heavy wind, run through the tops or crowns of the trees; brush fires burn the bushes and dry shrubs from 5 to 10 feet high; timber fires consume the entire forest-crown, stem, ground cover, and undergrowth-and usually occur in timber that stands close together.

Losses by Forest Fires on the National Forests. The results of forest fires naturally vary with the kind and intensity of the fire. Crown and timber fires do the most damage, and ground and brush fires do less. While the ground fires and brush fires seem to do very little damage to the valuable timber, still they may greatly reduce the productive power of the soil and destroy the watershed cover. Severe ground fires may kill valuable timber by girdling the trees. The great fires of August, 1910, 
which swept northern Idaho and western Montana destroyed millions of dollars' worth of timber and 85 human lives, and cost the United States $\$ 839,000$ for fire fighting. These were timber fires and they occurred for the most part in valuable stands of dense timber.

The forest fire losses on the National Forests for the last 9 years show a very great and gradual reduction of losses due to forest fires. In 1908, the total loss through fires was $\$ 451,188$ and in 1909 it was $\$ 297,275$. In 1910 , the year of the great fires in Montana and Idaho, there were very heavy losses in timber and human lives, due to an unusual combination of dry weather and high winds. But in that year the fire organization was not complete; it had never really been tried out. In this year the organization received its first severe test, and while it did the best it could with the available men and equipment, the situation in Idaho pointed out conclusively the weak points and the short-comings. The proof of these statements is found in the statistics of the next 5 years, when the average total loss for 1911 to 1915 , inclusive, was $\$ 293,000$, and, it must be remembered, several of these years were equally as unfavorable, so far as dry weather and 


\section{8 OUR NATIONAL FORESTS}

high winds were concerned, as the year 1910. During these years, however, the fire fighting organization had a good chance to be tried out thoroughly; for, as is quite evident, experience is the greatest teacher in this kind of work. During the calendar year 1916 the fire losses reached a new low level, compared to other years, the losses amounting to only $\$ 198,599$. In 1917 they were higher.

The Forest Fire Problem Stated. Having seen a little of the causes, behavior and results of forest fires on the National Forests, it is comparatively easy to state the forest fire problem as it occurs on the National Forests. Briefly stated, it is this: With the funds, organization and equipment that are available, the aim of the Forest Service is to keep the area burned over each year (and therefore the damage done) down to an accepted reasonable minimum. But the problem is not as easily worked out as it is stated, due, largely, to a great many uncontrollable and variable factors which cannot be foreseen in advance, the most important of which are the weather conditions. As has been said before, there are two general ways of keeping the area burned over down to an accepted reasonable minimum: either prevent the fires from getting 

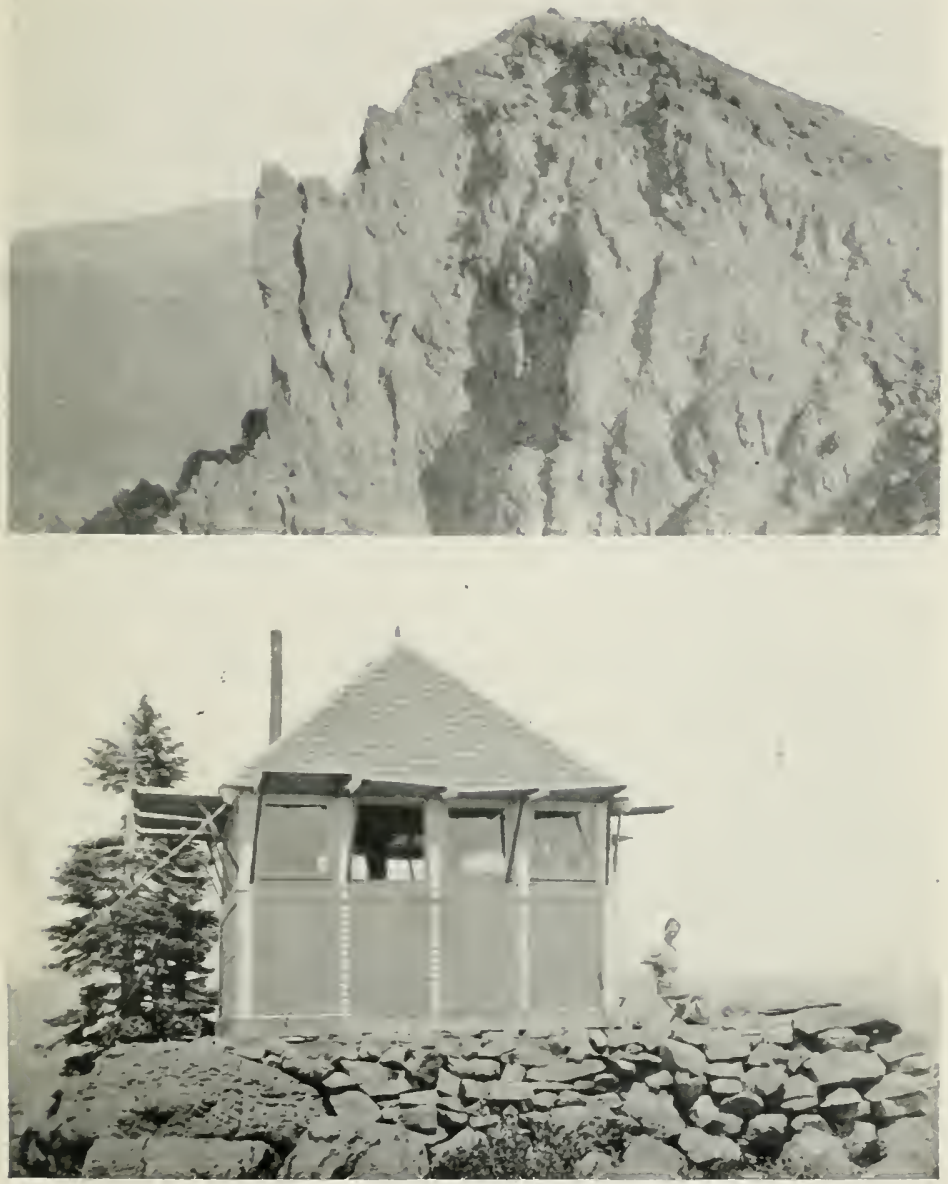

Figure 3.5. A forest fire lookout station on the summit of Brokeoff IIountain, elevation 9,500 feet. Lassen National Forest, California. Photo by the author.

Figure 36. Turner Mountain lookout station, Lassen National Forest, California. This is a $10 \mathrm{ft}$. by $10 \mathrm{ft}$. cabin with a stove and with folding bed, table, and chairs. The forest officer stationed here watches for forest fires day and night throughout the fire season. Photo by the author. 

started (as in the case of those started by human agencies) or, after they get started, to get to them with men and fire fighting implements in the shortest possible time after they are found. The former is called fire prevention, and the latter fire suppression or control. How the organization of the $\mathrm{Na}$ tional Forests solves these two problems is of the greatest interest.

Fire Prevention. The measures employed for fire prevention may be either administrative, legislative or educative in nature.

The most important administrative measures employed to prevent fire are those that aim to reduce the amount of inflammable material in the $\mathrm{Na}$ tional Forests. This is done in many different ways. The free use timber policy enables Rangers to give away much dead timber, both standing and down. Timber operators cutting on the National Forests are required by the Forest Service contract to remove dead snags, which are a fire menace, from the timber sale area. Where there is fire danger, all slashing resulting from such sales must be burned or otherwise disposed of. While grazing is usually not considered a measure to prevent fires, still grass lands that have not been grazed over 
become very dry in the fall and are a dangerous fire menace. Wherever it is feasible, old slash left by lumbermen on private lands adjacent or near to the National Forests are burned, when the fire can be confined to a small area. Another administrative measure is the reduction of the causes of fires by a patrol force. Forest Guards travel along the highways where there is most traffic and most danger. Their presence often is enough to remind campers, hunters and fishermen to put their camp fires out before leaving them. These patrolmen mix with the people and, if necessary, remind them in a courteous way to be careful to extinguish their camp fires before breaking camp.

Most of the necessary legislative measures for preventing forest fires already exist. The $\mathrm{Na}$ tional Forest force is seeking merely to obtain a strict enforcement of existing laws. Railroads are required to use spark-arresters on their locomotives and to provide for keeping their rights-of-way free from inflammable material. Logging camps must also prevent the destruction of National Forest timber by fire by using spark-arresters on all logging engines. The Forest officers are ever on 
the alert for the detection and apprehension of campers for leaving fires unextinguished and incendiaries for starting fires willfully. These careless individuals are arrested by them without warrant, either under the Federal laws, if the fire occurred on National Forest lands, or under the State law, if it occurred outside of government lands.

Educational measures are for the purpose of educating both the local forest-using public and the general public who may travel through the Forests in the careful use of fires in the forests. Forest officers, especially Rangers, come into personal touch with local residents and users, that is, the ranchers, stockmen, business men, loggers, campers, hunters, fishermen and others. Such people are often reminded by personal appeals by the Forest officers. Most of them have learned by this time, because of having been called upon to help fight fires at one time or another, and having gotten a taste of the result of other people's carelessness. Many written appeals are also sent out by the Supervisor and are slipped into the envelopes when grazing permits and other official documents are mailed. One of these written appeals, and prob- 
ably the one that has been used most widely, is known as the six rules for the prevention of fires in the mountains:

1. Matches.-Be sure your match is out. Break it in two before you throw it away.

2. Tobacco.-Throw pipe ashes and cigar or cigarette stumps in the dust of the road and stamp or pinch out the fire before leaving them. Don't throw them into the brush, leaves, or needles.

3. Making camp.-Build a small camp fire. Build it in the open, not against a tree or log, or near brush. Scrape away the trash from all around it.

4. Leaving camp.-Never leave a camp fire, even for a short time, without quenching it with water or earth.

5. Bonfires.-Never build bonfires in windy weather or where there is the slightest danger of their escaping from control. Don't make them larger than you need.

6. Fighting fires.-If you find a fire try to put it out. If you can't, get word of it to the nearest United States forest ranger or State fire warden at once. Keep in touch with the rangers.

Besides these kinds of appeals, many kinds of fire warnings are posted at conspicuous places along roads and trails to remind the public to be careful with fire in the Forests.

An attempt is also made to reach the general public, that is, those living outside the local communities, but who occasionally travel through and use 

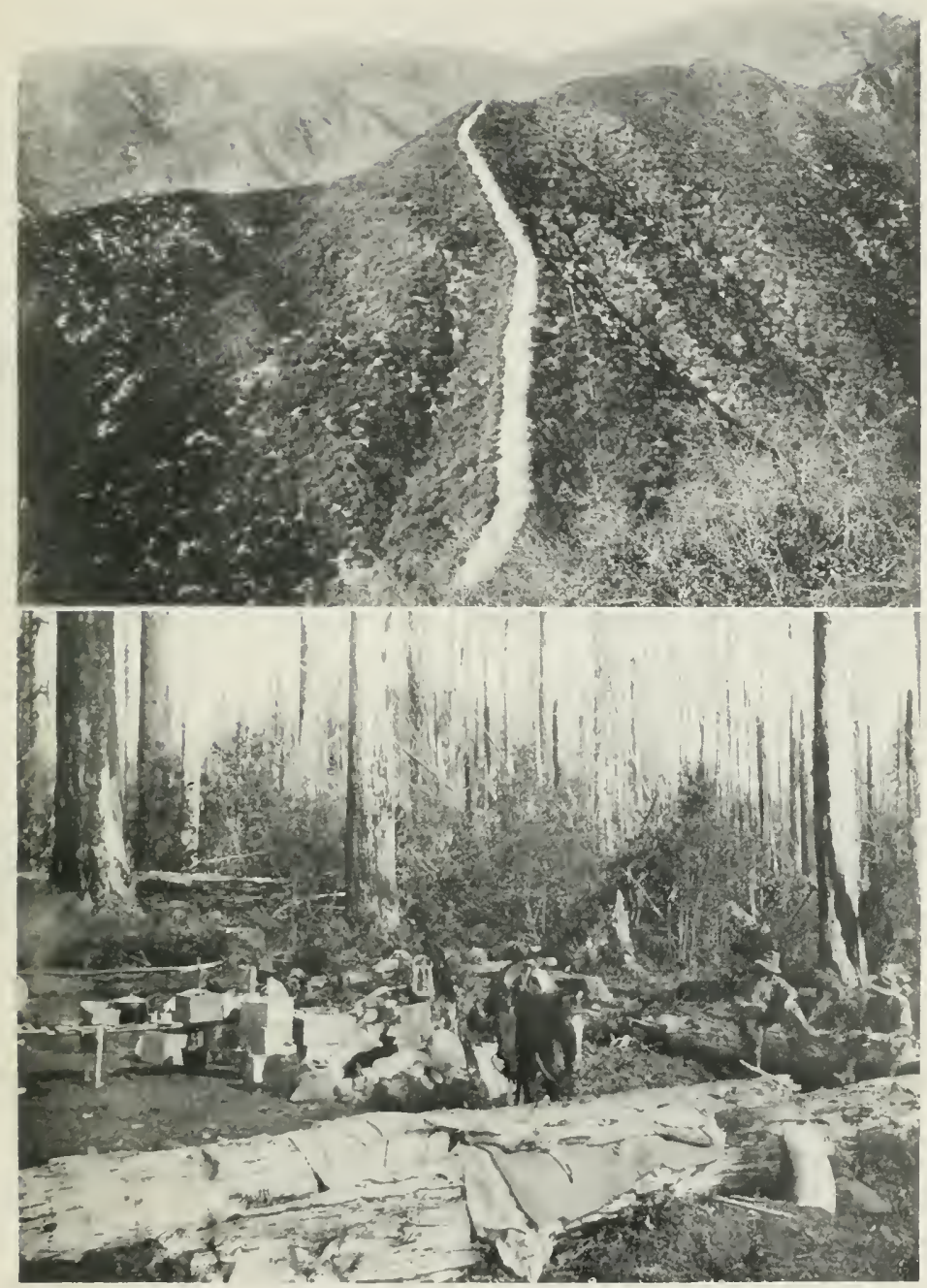

Jigure 3i. I fire line cut through the low bush-like growth of "Chaparral" on the Angeles National Forest, California. This "Chaparral" is of great value for regulating stream flow. "The streams are used for water power, domestic purposes, and for irrigating many of the largest lemon and orange groves of southern California.

Figure 38. A forest officers' temporary camp while fighting forest fires. Near Oregon National Forest, Oregon. 

the National Forests. Many hundreds of thousands travel through the Forests every year by automobile or by other conveyances. These people camp in the Forests, fish, hunt, and enjoy the cool climate and beautiful scenery. Before they start on their trips, that is, while they are still in their home towns, and also while they are on their way, many means have been devised to reach them. They are confronted with newspaper advertisements, folders, booklets, and other printed matter. In towns and cities, public meetings, lectures, exhibits, expositions, county fairs, commercial clubs, and the chambers of commerce, all help, either directly or indirectly, by one means or another, to inform the people of the great fire danger on the National Forests. Even the letters sent out by the District Forester and the Supervisors have written appeals affixed to the outside of the envelopes by means of a rubber stamp. In short, every possible means is used to educate the public that uses the $\mathrm{Na}$ tional Forests and in whose interest, in fact, the Forests are being maintained and protected.

Fire Suppression. So much for the problem of fire prevention. In case a fire does get started, and there are thousands of them on the National For- 
ests every year, the problem, as has been said before, consists of getting men and tools to it in the shortest possible time, in order to keep the damage down to the lowest possible point. To do this, a vast organization has been formed by the Forest Service, which is not unlike the Minute Man organization of Revolutionary days. A brief outline of this organization and how it works when a fire starts will give my reader a still better idea of what the Forest Service is doing in forest fire protection. But before speaking of this organization, a few preliminary matters are of interest; they deal with the manner of distributing fire protection funds, forest fire history, and the study of weather conditions.

How Forest Fire Funds Are Distributed. It devolves upon the Forest Supervisor and also the District Forester to apportion the appropriation allotted for fire protection in the most economical and efficient manner. First of all, the money is allotted to the various Forests in proportion to their needs. These needs are measured by the size of the Forest, the value of its resources, the length of the dangerous dry season, the fire liability or the amount of money loss in case of fire, the fire hazard 
or the degree to which an area is subject to fire danger, the difficulty of prevention and control and many other factors. These same factors are employed to apportion the Supervisor's allotment of money to the various Ranger districts on his Forest.

Probably the most difficult factors for the Forest Supervisor to appraise on each Ranger district are the fire liability and the fire hazard. Fire liability has to do with the amount of damage a fire could do if it got started. Valuable timber needs protection most of all, and the value of the forest is determined by the kind of trees in it and the density of the stand. Fire hazard is usually expressed in terms of risk. The Supervisor asks his Ranger if the risk on a certain area in his district is high, low, or medium. Risk depends, of course, largely upon the character and inflammability of the forest cover and the presence of human causes. Dense forests involve greater risk than open, scattering trees; government forests interspersed with private holdings containing much old slash have a high risk factor; and government forests near sawmills, large towns, and along railroad rights-of-way also have high risk factors. All these matters must be consid- 
ered, in order that each area on each Ranger district gets just enough money for fire protection and not a bit more.

Forest Fire History. Very important also in fire protection are the studies which the Forest Service is carrying on, dealing with forest fire history. For many years back, records have been kept on all fires : their causes, area burned over, date of the fire, damage caused, the exact location of each fire, the cost of fighting it, the total number each month and each calendar year, and many other data. More recently records have been kept upon still further details connected with each fire, such as: the time elapsed between the start and the discovery of a fire, between the discovery and the report to the proper official, between the report and the beginning of the actual work of fighting, and the time required to put the fire out. Intensive studies have been made also upon the length and character of the fire season on each Forest, for it is important to know the maximum length, the minimum length and the average length of the fire season. These data show how much extra help must be hired for fire patrol and fire fighting, and during what periods the greatest damage is done, based both on acreage 

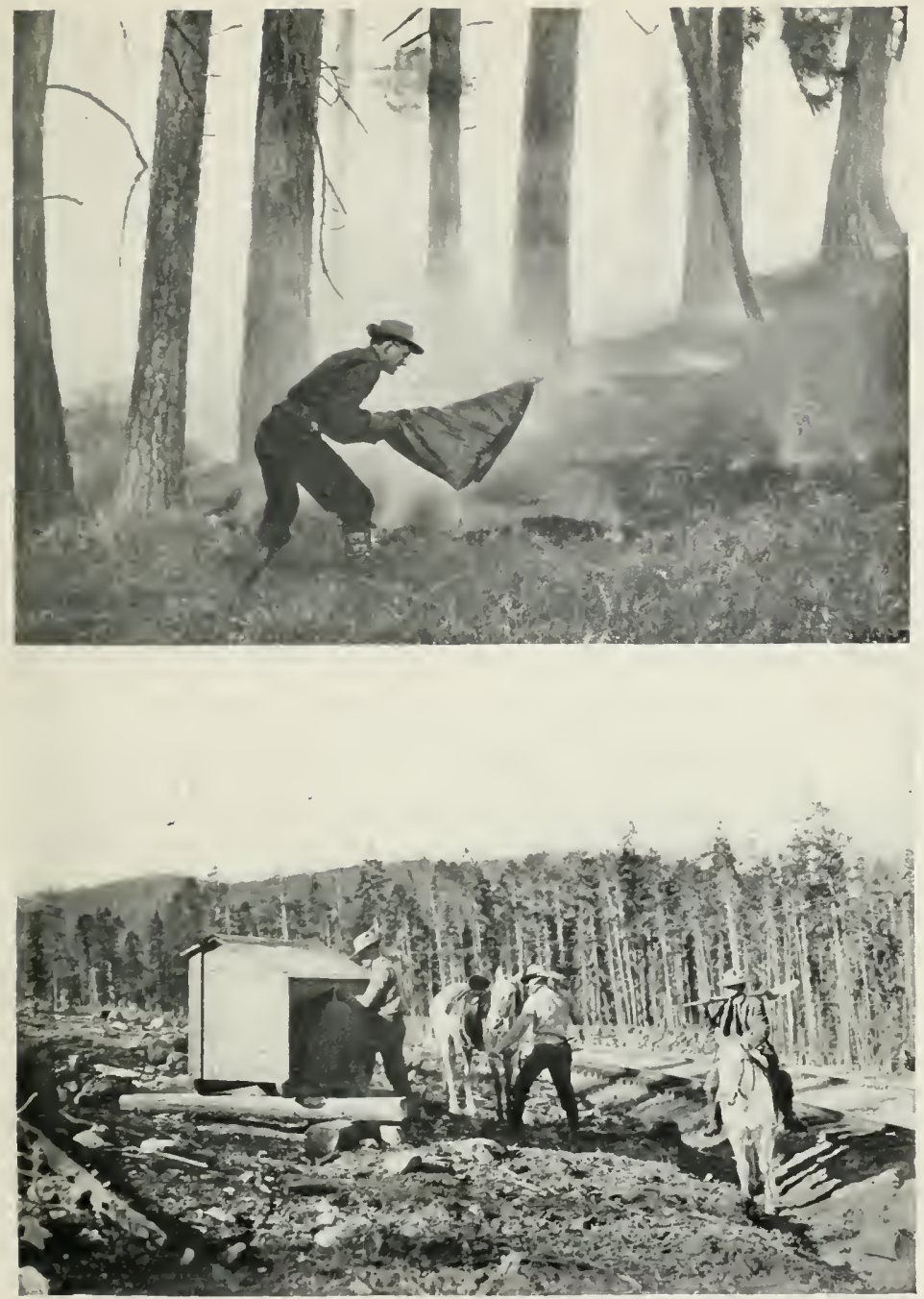

Figure 39. Putting ont a ground fire. Even if the fire does not burn the standing timber, it kills the young trees and so weakens the larger ones that they are easily blown over. Wallowa National Forest, Oregon.

Figure 10. Forest officers ready to leave a tool box for a forest fire in the vicinity. Such tool boxes as these are stationed at convenient places on National Forests ready for any einergency. Arapalıo National Forest, Colorado. 



\section{PROTECTION}

burned over and by the number of fires. Studies of this kind yield positive information on what areas ach Fo. est are particularly liable to lightning to canıp fires, and to incendiary fires. With 1 nowledge the Forest Supervisor can plan and distribute his men and funds more intelligently; they tell him during what period he can expect the most trouble, and therefore must have the greatest number of fire fighters at his command. It is scientific study like this that is doing more than anything else to solve the fire protection problem in the Wes rn States.

Relation, of Forest Fires to the Weather. In coöperatic 1 with the United States Weather Bureau, the Forest Service studies weather conditions in $r$ 'ation to forest fires. Weather forecasts have be ent to each Forest Supervisor throughout the $1_{s}$ a season, informing him of the probable weather conditions. The velocity and duration of the wind, the temperature, the precipitation, and the relative humidity are all factors which greatly affect the inflammability of the forest. Forest Supervisors have been informed in these forecasts of what are known as emergency conditions, that is, an unsual and abnormal combination of weather 
conditions which make fire danger very great. These conditions may be a high wind, low relative humidity, high te: neratures, or a combination of the three. When a : rost Supervisor is informed by the District Fore - chat emergency conditions are likely to exist during the next ten days or so, he immediately sends an alarm to all his Rangers to be especially watchful.

Improvements and $\boldsymbol{E}_{4}$ uipment for Protection. After the preliminaries of fire protection finance, forest fire history, and the tudy of weather and emergency conditions have a a worked out, probably the first and most impu tant prerequisite to forest fire protection is a matter already spoken of, namely, the improvements and the equipment. The construction and maintenance of improvements and the possession of suitable eqr mant is second in importance only to the organizia

do the actual fire suppression. Roa

phone lines, fire lines, lookout stations Ranger $x^{\circ}$ tions, tool and food caches, a central su.

and many other things are necessarv

can be effective. Each Forest Rangeri the following equipment: fire fighting tools, water bags and pails, teams, pack horses, wagons, auto- 


\section{PROTECTION}

mobiles, saddle horses, tents, portable telephone lines, riding and packing equipment, and many other special equipment, whic ust be hired when occasion for its use ari if a Forest Ranger has not access to this equip. ent, and few of them have, he has hanging by his telephone a complete list of all the stores, stables, garages, etc., in the neighboring towns and how much equipment each can furnish when called upori.

Forest Fire Maps and Charts. Not the least important bit of ec" ment, by any means, is the fire map or maps. ' the Forest Supervisor has a fire map of his whille forest in his office and the Forest Ranger has one of his district (sometimes including the neighboring districts, too) hanging in his cabin, usually posted conspicuously, so that it can be referr to any time of the day or night without delay. These maps have upon them all the available information regarding the country which is to bet protected. They show physiographic features, 通 as topography, creeks, springs, meadows, $w$, er, swamps, etc.; vegetative features, such as ti areas, regenerating areas, slashings, etc.; such manmade features as roads, trails, cabins, ranger sta- 
tions, corrals, pastures, Supervisor's headquarters, sheep camps, cattle camps, ranches, camp sites, railroads, logging railroads and camps, sawmills, power plants, towns, villages, etc.; and special protective features, such as locations of men, tools, equipment, tool and food caches, local help, emergency help, fire lines, fire breaks, lookouts, government and private telephone lines, instruments and switchboards, locations of stores, state Fire Wardens, livery stables, pack trains, garages, stage routes, etc. All these features and data are not put upon one map; usually a series of maps are used or some of the information is put on charts or on the border of the maps. In short all this information is put in such form that it is available at the shortest notice for emergency conditions. It makes little difference how it is recorded, so long as the information is available when needed.

Forest Fire Organization. The forest fire organization, whether it be on the whole National Forest or upon the Ranger district, consists of three agencies: the fire detection agencies, the fire reporting agencies, and the fire fighting agencies. All these must work in absolute harmony without interruption of any kind, to obtain the maximum of 


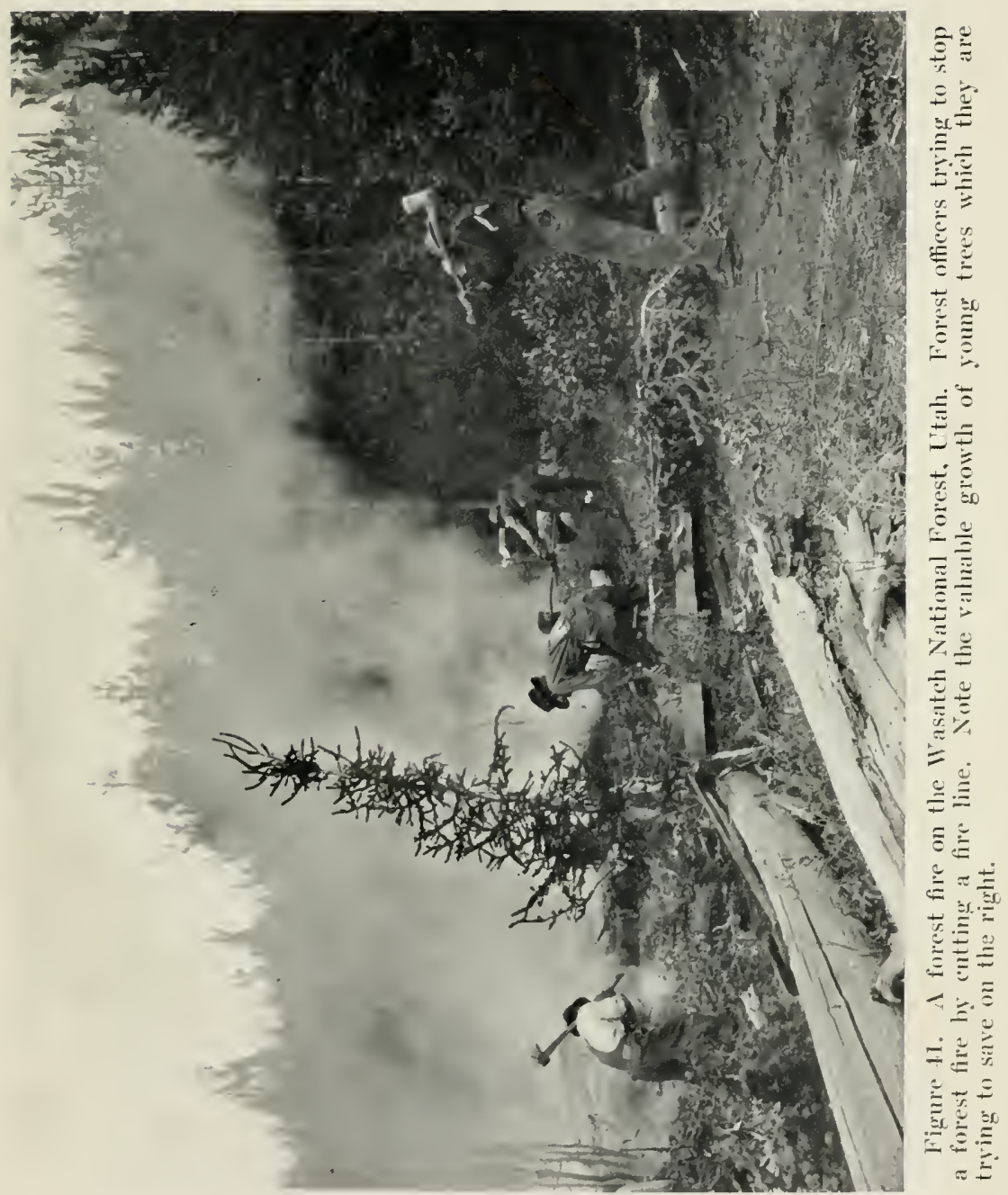



efficiency. The detection agencies consist of the look out men, stationed at high, advantageous po its which overlook large areas, and the moving patrolmen, who are assigned to definite beats or territory which cannot be adequately reached by the loskouts. Lookout men live in small cabins on the $\imath$ ps of high mountains, and they watch for fires constantly. In regions which have very few high points and which are not suited to that method of detection, moving patrolmen are employed. These men move about on foot, on horseback, on railroad speeders, in automobiles, or in any other conveyance adapted to the country they are in.

When the detectors find a fire they report it immediately to the nearest Forest Ranger or the Forest Supervisor. The Forest Ranger in whose district the fire is located is logically the first man to be informed, but telephone connections and other conditions sometimes alter this procedure. Just because a fire is found in, we will say, Ranger district number one, does not necessarily mean that the Forest Ranger of this district is the proper man to be notified. The fire may be at the very outer boundary of his district and may be much more easily accessible to the Forest Ranger in district 
number two. In any case it is all arranged beforehand just exactly who shall be notified in case of a fire in each and every corner of a National Forest. Each man in the organization has his duties and responsibilities determined for him in advance and he does his part without being prodded or reminded. The location of a fire in the wild and inaccessible forest regions of the West, which may seem a very simple matter, is determined in a very ingenious manner.

How Fires Are Located. The lookout man, as well as the Forest Rangers and the Forest Supervisor, is provided with identical maps of the Forest. These maps show most of the important features useful in fire protection work, including also the private lands, all government holdings, and the public land survey. This public land survey has divided the land surface into legal subdivisions known as townships, sections, and quarter sections, and it is by these and with reference to these that all features, both natural and artificial, are located. A township is usually a square 6 miles on a side, containing 36 sections. Each section is divided into quarter sections containing 160 acres each, which are further divided (though not by law) into forty- 


\section{PROTECTION}

acre squares. The problem, therefore, that confronts the lookout man upon the discovery of a forest fire is to inform the Ranger or other Forest officer where the fire is-that is, in what section it is located, if it cannot be located with reference to some well-known natural feature.

In order to determine in what section or quarter section a fire is located, each lookout point on the Supervisor's and Rangers' fire maps has a transparent circular protractor mounted on it. (A protractor is a device by which angles are marked off; it consists of a circle upon whose arc the degrees from 0 to 360 are indicated, 0 degrees being equivalent to North, $90^{\circ}$ to East, $180^{\circ}$ to South and $270^{\circ}$ to West.) The center of the protractor is the lookout point. A piece of black thread is fastened to the center of each lookout point, so that it can be stretched across the arc of the circle and the degrees read off. The other end of the thread has fastened to it a thumb tack or similar device, so that when the thread is stretched to read a certain angle, it can be fixed at that angle. The maps of the lookout men are usually fastened or permanently mounted upon a table which is oriented (that is, the top of the map is turned toward the north). The 


\section{OUR NATIONAL FORESTS}

lookout men have sighting devices, usually alidades, which are placed on the map, by means of which they sight at a fire; but the bearing of the fire is read from the angles marked on the edge of the map, which is in reality a large protractor.

By these devices a fire is quickly and accurately located. When the lookout man sees a fire, he gets its bearing from the map by means of the sighting device. He telephones this bearing to the Ranger, or, in many cases, to the Supervisor. Immediately the Supervisor goes to his map, picks up the black thread attached to this lookout point, stretches the string, and, having marked off the bearing, pushes the thumb tack into the map. In the meantime, another lookout, perhaps two more, have sighted the same fire. The black threads from the other lookout points on the Supervisor's map are stretched and fixed in a similar manner. The fire will be found to be at the point where two or more of these black threads intersect. This is only one of the many ways which have been devised to locate forest fires; there are other methods, but all are based upon the same principle.

The Fire Fighting Organization. The organization of men who do the actual fire suppression 


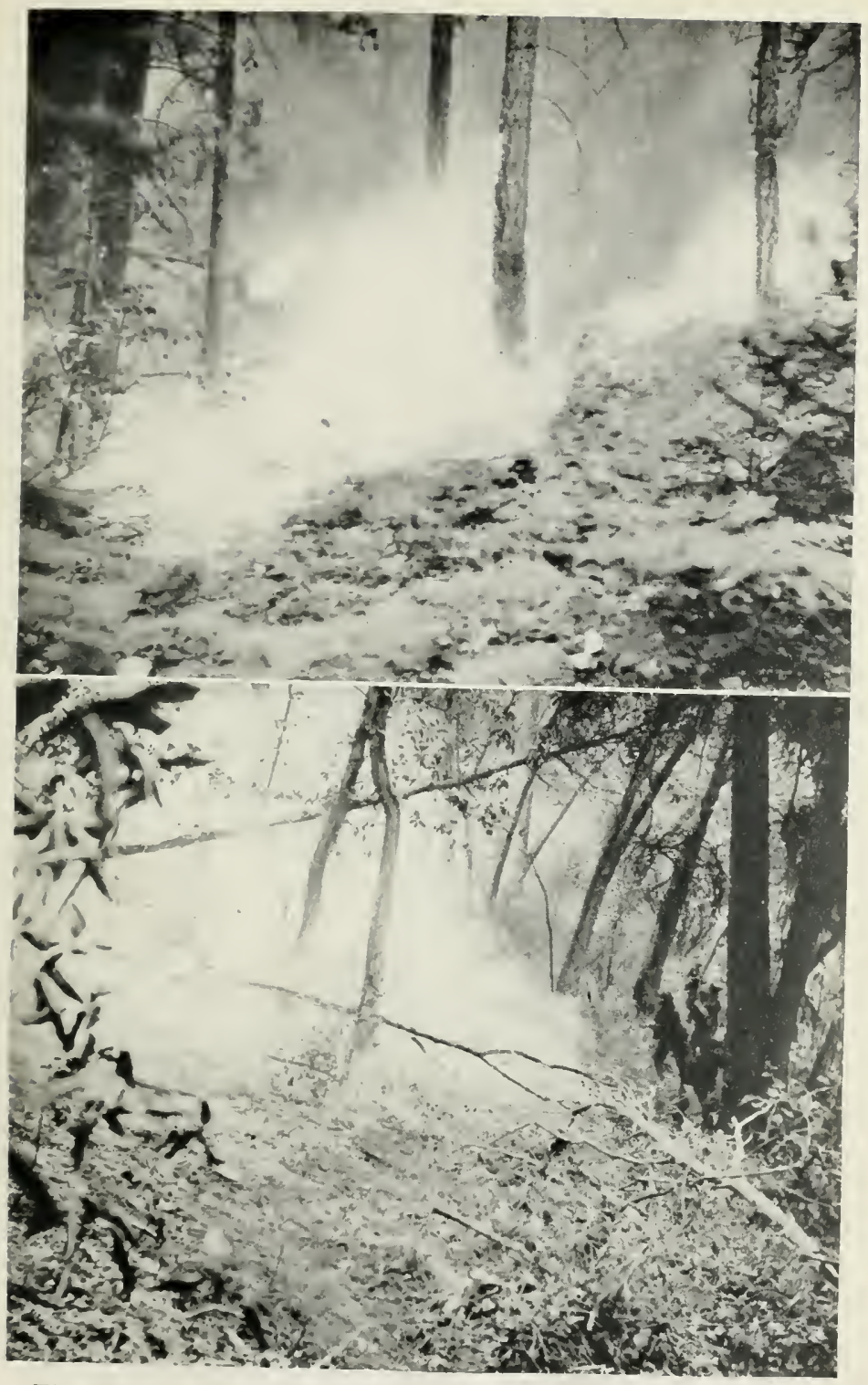

Figure 42. A forest fire running in dense underbrush on one of the National Forests in Oregon.

Figure 43. Jen in a dense forest with heavy undergrowth elearing away brush to stop the fire as it is running down hill. Crater National Forest, Oregon. 
must be an elastic one, adequate to meet the needs of a Ranger district or of a whole National Forest, or, in some cases, of an entire administrative district, comprising as many as 25 to 30 National Forests. The Forest Guards and Forest Rangers are known as the first line of defense in this war against forest fires. Upon them falls the brunt of the work of fire suppression. The second line is composed of local stockmen, ranchers, and logging and sawmill crews. When these prove insufficient in number, the large villages and towns are called upon, and the last resort is the labor of the cities and the United States Army. Thus, in the case of a very large fire the organization of the Forest Service is modified to cover not only each and every National Forest, but also entire States. In case of a very large fire, every available man from each Forest is sent to take his place in the organization. Expert fire fighters are sent direct to the fire. Other Forest officers are sent to the large towns and villages to act as quartermasters. These men hire fire fighters, entrain them, and fill orders for food, bedding, tools, and other equipment. Other quartermasters at the scene of the fire check shipments of supplies, check the time of fire fighters, approve 
accounts, hire transportation, and perform similar duties. Special disbursing agents are sent to the scene to pay the men. In short, everything is done to dispatch as quickly as possible the necessary men, food and equipment to the fire, and to do it in accordance with the prearranged plan for such emergencies.

Forest Fire Coöperation. A very important part of the plan of fire protection on the National Forests are the coöperative agreements entered into between the Forest Service and private individuals or companies. Such coöperation may be in the form of building improvements for fire suppression, furnishing men in case of fire, furnishing lookouts or patrols, furnishing equipment, and, in fact, in connection with any of the necessary means for fighting fire. This coöperation has been of mutual benefit. One National Forest may coöperate with one or more neighboring Forests or with sawmills, power plants, logging camps, or railroad companies. Coöperation may also be with a wellorganized Forest Protection Association, of which there are a large number in the Western States. These coöperative agencies agree to send a large force of their men to fires on the National Forest 
in their vicinity, and the Forest Service reciprocates by sending men for fires occurring on their lands, which may threaten National Forest timber. Often coöperative agencies enter into agreement to build jointly with the Forest Service certain improvements, such as telephone lines, lookout towers, or trails, which will benefit public fire protection as well as private. Many sawmills and logging companies who operate on or near the $\mathrm{Na}$ tional Forests have agreements with the Service, by which they suspend all operations and send all their help to fires which threaten National Forest timber. All timber sale contracts of the Forest Service provide for coöperative fire protection.

Fighting Forest Fires. The most important requirements for successful fire suppression are: quick arrival after discovery, adequate forces of men, proper equipment, thorough organization on the fire line, skill in attacking, and careful, systematic patrol after the fire is thought to be out. All fires, whether large or small, require generals to lead the attacking forces, and the strategy of fire fighting can only be learned after long experience on the fire line. A cool, level-headed man is the greatest necessity in an emergency, for it is as 


\section{8}

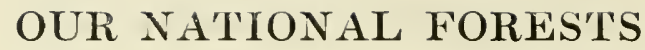

disastrous to get too many men as it is too few. A few men that know how to attack a fire are worth a great deal more than a great many that are inexperienced.

There are different kinds of fires, depending upon their size, their intensity, and the nature of the country in which they are burning. And there are as many different methods of fighting fire as there are kinds of fires. Some fires, such as grass fires or those burning in the needles and litter in the forest, can be extinguished directly by being smothered or beaten out. For this purpose Rangers sometimes use their saddle blankets, when nothing else is handy, but usually wet gunny sacks, boughs, and tree branches are used. Often, if it is available, sand or dirt is thrown on the fire with a shovel. Surface fires are a little more difficult to extinguish. 'They are more intense and more swift and consume brush, young growth, and fallen dry trees. These usually cannot be attacked directly, but must be controlled indirectly by the building of a trench or a fire break, or by a system of back firing. Trenches are fire breaks in miniature, usually from one to several feet wide. Fire breaks or fire lines are broad belts from 30 to 50 feet wide, which are 

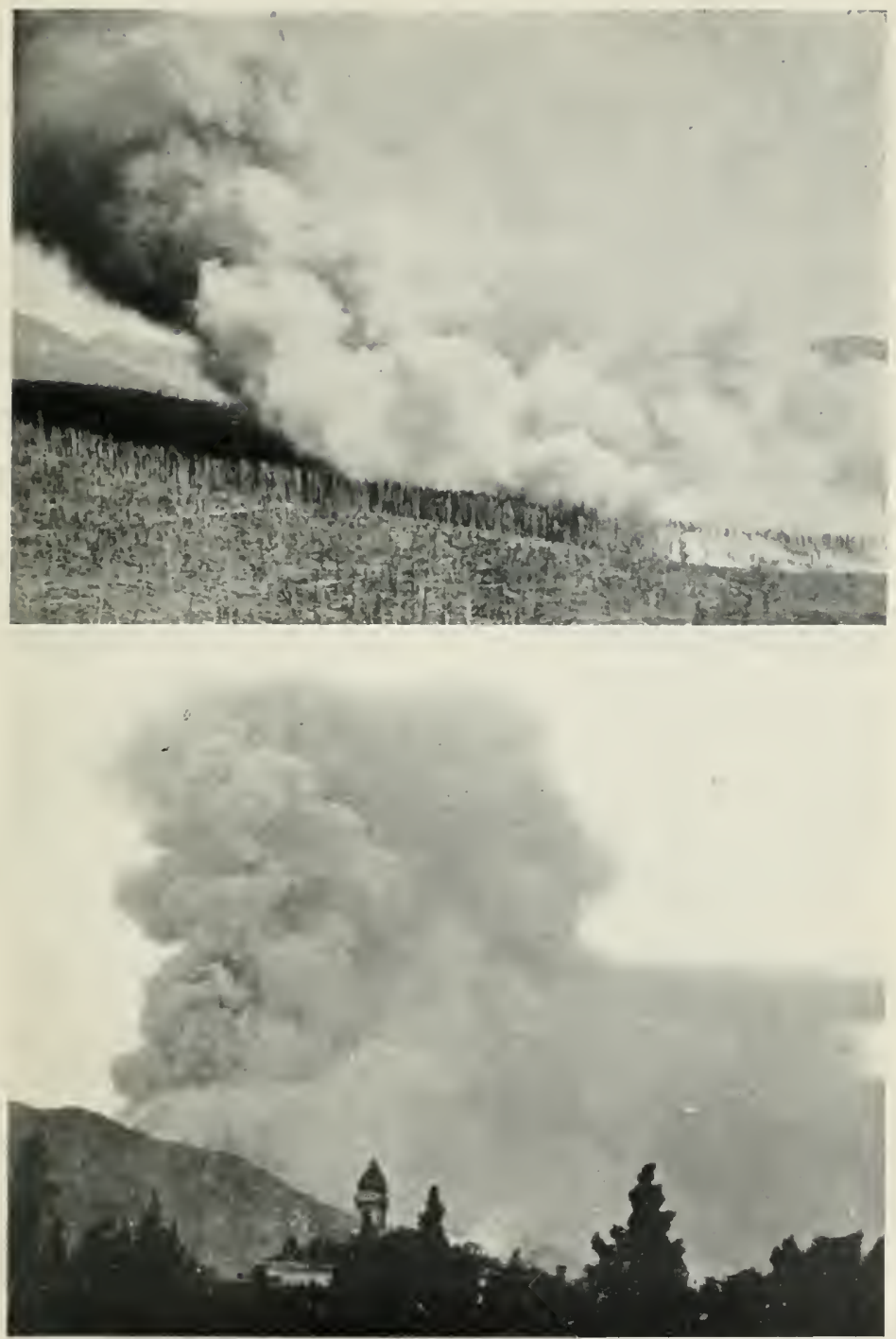

Figure 4t. Fire in a Lodgepole pine forest in Colorado. Arapaho National Forest, Colorado

Figure 15. A mountain fire in "Chaparral," five hours after it started. Pasadena, California 



\section{PRO'TECTION}

cleared of inflammable material, not so much to stop the fire when it reaches this belt as to furnish a safe area from which fire can be fought and, most of all, from which back firing can be started. These lines or belts are usually built along ridges. If a fire starts on the lower slope of a mountain and the wind carries it up the mountain toward the fire line, the only hope of stopping the fire at the top of the ridge at the fire line is to start fires on the top of the ridge, which will burn down the slope and meet the original fire coming up. In rare cases, as, for instance, in the Idaho fires of 1910, the fires get to be so large and swift that all methods of attack prove futile and the only salvation is in natural barriers, such as rivers, or a change of the wind, or rain, to extinguish them.

In all fire fighting work, the plan is to surround the fire (if it cannot be beaten or smothered out) by a trench, fire line, or fire break, and to prevent the fire from spreadng. In this kind of work, shovels, spades, mattocks, rakes, and hoes are used to move the soil; saws and axes are used to remove fallen trees from the fire line, and in some cases plows, dynamite, and other implements are employed. 
PROTECTION AGAINST TRESPASS, FOREST INSECTS, EROSION, AND OTHER AGENCIES

While the protection of the Forest resources from fire is probably the most important phase of forest protection, it is not the only one by any means. The National Forest force also protects the Forest resources from trespass, from insect damages, and from tree diseases. Also water supply for domestic use, for irrigation, waterpower, and navigation must be protected, and the public health must be safeguarded against the pollution of the streams emerging from the Forests. It is also the duty of Forest officers; in coöperation with the state authorities, to protect game, fish, and birds from illegal practices.

Trespass. The Act of June 4, 1897, authorizes the Secretary of Agriculture to make rules and regulations for the occupancy, use and protection of the National Forests, and provides that any violation of such rules and regulations shall be punishable by a fine or imprisonment or both. This and later acts provide for fines or imprisonment for all violations of the regulations governing National Forests. The violation of these regulations consti- 
tutes trespass, and these may be either fire, timber, grazing, occupancy or property trespass, depending upon the offense. Since the United States has all the civil rights and remedies for trespass possessed by private individuals, it may bring action to recover damages resulting from trespass or breach of contract.

Fire trespass includes the following offenses: setting fire to timber, brush or grass; building camp fires in dangerous places where they are hard to extinguish; or leaving camp fires without completely extinguishing them. The various railroads that cross the National Forests are one of the most frequent offenders in that the sparks issuing from the locomotives or the hot ashes dropping from the fire box set fire to National Forest timber. The railroads are required to use every precaution to prevent such fires, but many of them are started, resulting in damage suits by the Government. The damages cover not only the merchantable timber and forage destroyed, but damages are also collected for young, immature growth, which at first thought might seem to have little or no value. But the courts have held that while the young, unmerchantable trees have very little value now, they 
have a great value as the basis for a future crop of timber. Thus, in the case of the United States versus the Chicago, Burlington and Quincy Railroad, in 1910, for fire trespass on the Black Hills National Forest, caused by sparks from the locomotives operated by the company, the damages included $\$ 17,900$ for young growth. Also, in the case of the United States versus the Great Northern Railroad, in 1911, in which suit was brought upon the negligence (causing fires to start) of the defendant company on their right-of-way, which fires subsequently spread to the Blackfeet National Forest, damages included the destruction of a great many immature trees, the value of which was estimated on the basis of their value at maturity discounted to date. It is significant that this case never went to trial; the defendant paid damages and costs without argument.

Under timber trespass are included the following acts: the cutting, killing, girdling, or otherwise damaging trees; the cutting of timber under sale contract or permit before it is marked by a Forest officer; the removal of timber before it is scaled, measured, or counted by a Forest officer; and the fraudulent stamping of any timber belonging to the 


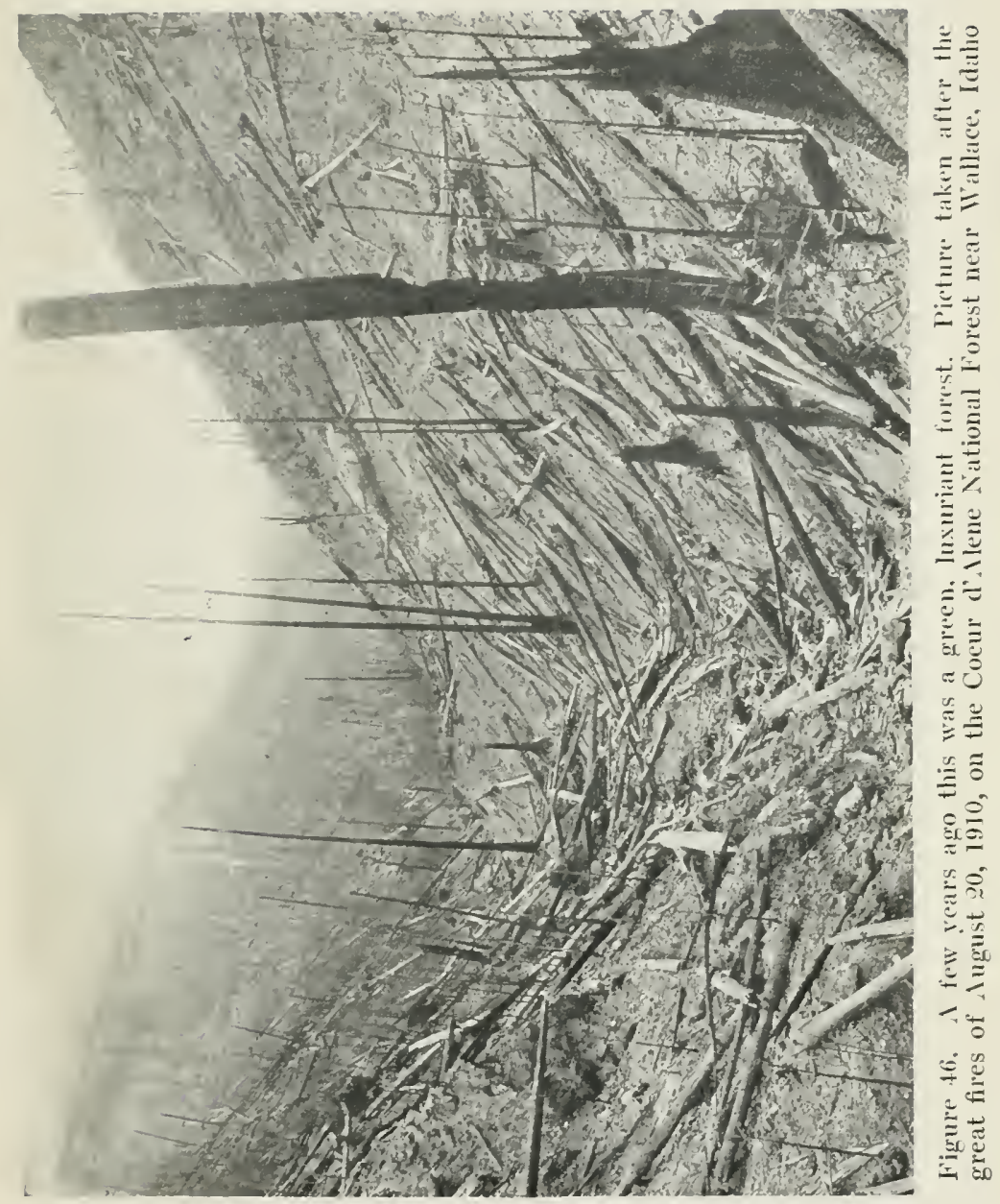



United States with the regulation marking tools or similar device. Under grazing trespass are included such acts as: grazing stock on National Forest lands without permit; grazing stock on areas which are designated as closed to grazing; driving stock across a National Forest without permit; and refusal to remove stock upon instructions from an authorized Forest officer when an injury is being done to the National Forests by reason of the improper handling of the stock. The use of National Forest land without a permit for any purpose for which special use permits are required constitutes occupancy trespass. But traveling, temporary camping, hunting, surveying, or prospecting may be carried on without permit, and camp wood and forage for stock used in connection with such activities may be taken free of charge. The unauthorized appropriation, damage, or destruction of property belonging to the United States, which is used in the administration of the National Forests, also constitutes trespass.

Innocent trespass is usually settled amicably between the trespasser and the Supervisor. If the violation of the timber, grazing, or land regulations was due to a misunderstanding and was not of a 
willful character, a permit is issued and the trespasser pays for the timber or special use, as under regulation. Fire and property trespass cases seldom can be construed as innocent, hence in most cases such offenses result in litigation.

Forest Insects. Protection against forest insects is carried out in coöperation with the Bureau of Entomology of the Department of Agriculture.

An essential part of good forest protection is the work of locating and reporting evidences of insect depredations. There are scores of insects which are constantly working in the forests, either injuring or killing live trees or attacking the wood of trees after they have been killed. Weevils kill young shoots on trees and destroy tree seeds; bark beetles and timber beetles infest the bark, girdle the tree and destroy the wood; and various borers and timber worms attack seasoned and unseasoned forest products and destroy the wood in the forest after it has been cut down and sawed into lumber. The greatest annual loss by insects is caused not so much by conspicuous local outbreaks as in the sustained annual loss of scattered merchantable trees. Local infestations often kill a large percentage of trees on an area, but these outbreaks are easily seen; 
the scattered infestations that kill a tree or two here and there over large forest areas are not so noticeable, but, taken all together, add up to a startling total.

The task of locating and reporting insect infestations falls upon the Forest Ranger and other field men of the Forest Service. Since the Rangers are practically the only class of Forest officers that visit all parts of a National Forest during each field season, the Supervisor relies mostly on them to report upon insect infestations. In riding to and from his work, while on fire patrol, while going for mail and supplies, while attending to the timber, grazing and other business of his district, the Ranger does a good deal of traveling and covers practically every part of his district. These are good opportunities to watch for fresh outbreaks of insects, and the wide-awake, progressive Ranger never misses such chances. If he sees reddish-brown masses of pitch and sawdust on the bark of a tree he immediately recognizes it as the work of insects. Or perhaps he may see a pine or a spruce tree with all its needles turned yellow. He knows then that this tree was girdled by bark beetles very recently, probably during the previous summer. A tree whose 
needles had turned red would indicate to him that the infestation was more than a year old, since trees attacked in the spring of one year usually do not show the results until the following summer. These two stages are known by the trained entomologist as the "yellow-top" and the "red-top" stages respectively. The latter is followed by the "black-top" stage. In this stage, insect infested trees stand out very conspicuously as leafless, gray or black snags, and they tell the story of the work of bark beetles that happened years ago.

Probably the first external evidence of the attack of a bark beetle upon living trees with normal green foliage, is the presence of pitch tubes upon the outer bark. These are small, reddish-brown (later becoming grayish-white) masses of pitch and sawdust, which exude from the small cylindrical entrance made by the adult beetle where it bores through the bark to begin its egg tunnel. Each tube represents the entrance of one or more of these beetles. But we must follow these egg tunnels further, to learn how the actual damage is done to the tree. As soon as the bark beetle has made its entrance through the bark, it starts to work up through the live bark and cambium of the tree, 


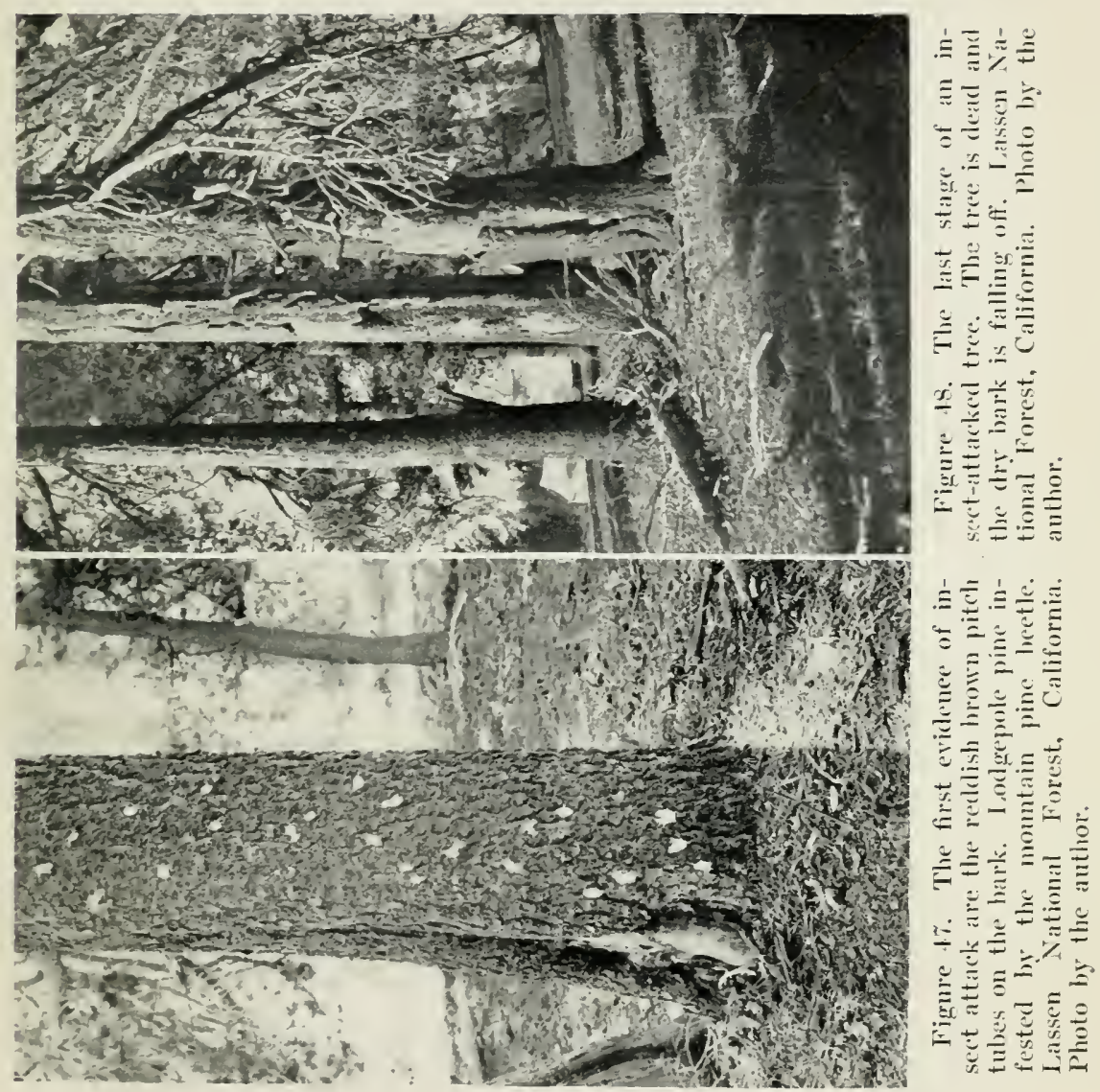



forming a tunnel but little larger than the diameter of the beetle, which is known as the egg gallery, These egg galleries vary in shape from straight to winding, and in length from ten to forty inches. As a rule, male and female beetles work together in one gallery, and the eggs are deposited along the sides of the gallery, often in little pockets. When the tunneling and egg-laying process of the adult beetles is completed, their activity ceases, and they are usually found dead at the upper end of their galleries. The larvæ hatch and begin their work by burrowing across the cambium at right angles to the egg galleries. The complete girdling of the cambium layer is not accomplished until the larvæ have completed their work, and the numerous larval galleries, by joining one another, form a complete gallery around the cambium of the tree, thus cutting off the food supply which is made in the leaves of the tree, from the lower portion of the tree, namely the roots. Since the roots cannot live without nourishment, the tree dies. As soon as the larvæ have completed their development they pupate. Later they develop into adult beetles. These adult beetles issue forth in swarms the following spring, to attack new trees. 
The control of insect pests is a difficult matter. On areas where insect depredations are conspicuous and are liable to spread to nearby valuable timber, control measures are undertaken in coöperation with experts from the Bureau of Entomology. In these control projects, crews of men fell the infested trees, strip the bark from them, and burn the bark (usually at a time of the year when the young broods of beetles are still in the bark, namely, fall or winter). Trap trees are sometimes resorted to. In this method, trees are girdled with an ax and thereby weakened to such a degree that beetles are attracted to it. After such a tree has become thoroughly infested in this manner, it is cut down and burned. In the case of a large, conspicuous infestation, an insect reconnoissance is made, in order to obtain an estimate of the percentage of trees that have been killed by insects. When it is possible, the timber is immediately sold. For example, on the Lassen National Forest, the writer several years ago made such an estimate of an infestation caused by the mountain pine beetle, covering over 100,000 acres. The reconnoissance showed that about $\mathbf{3 5}$ per cent. of the trees above 12 inches in diameter had been killed. The killed timber was subse- 
quently utilized for telephone and telegraph poles.

There are many administrative measures which are practiced on the National Forests, which aim to prevent insect infestation. The prevention and suppression of forest fires, which form infection courts for insects, is probably the most important one. In all timber sales, old dead snags and slashIng, which are breeding places for insects, are disposed of. Through free use and timber sales, insect-killed timber is disposed of and the loss due to insects is reduced to a minimum, besides in many cases destroying the young insect broods.

Tree Diseases. In almost every administrative district there is a Consulting Pathologist, connected with the Bureau of Plant Pathology of the Department of Agriculture, who has charge of all work dealing with the eradication of tree diseases.

A tree disease is really any condition that interferes with the normal functioning of the tree, be this condition caused by fungi, mistletoe, fumes, smoke, frost, sunscald, drought or excess of water in the soil. Parasitic fungi and mistletoes cause most of the tree diseases. Leaf diseases, by killing a greater part of the foliage, destroy the very organs in which food for the growing tissues is prepared. 
Diseases of the bark intercept the flow of food coming down in the bark from the leaves. Diseases of the sapwood cut off the water supply, which is pumped upward from the roots. Those that attack the roots also affect the water supply of the tree. Diseases of flowers and seeds destroy the faculty of reproduction.

Certain parasites are able to enter the youngest parts of trees, twigs and leaves directly, but the majority of the fungi causing decay of the wood can get into the interior of the living tree only by way of a pin knot or wound. For this reason, every wound caused by lightning, by fire, by man, or by animals, constitutes a menace to infection. Many coniferous trees cover their wounds by an aseptic coat of pitch, which is very effective in preventing the germination and growth of fungus spores. But the less resinous conifers and the hardwood trees do not cover their wounds very effectively; large wounds are not covered at all. Upon exposure by a wound, the sapwood just underneath the bark dies, dries out, and checks. Spores of parasitic fungi enter the cracks, germinate and infect the heartwood. The spores of a heartwood-inhabiting fungus cannot germinate and 
thrive unless they fall upon the heartwood of the tree. In this way certain diseases of the heartwood, which result in rot or decay, can very frequently be traced directly to fire scars, lightning scars, spike tops, broken limbs or branches, and other mechanical destruction caused by lightning, fire, storms, cloudbursts, or heavy snow-fall.

Fire as a cause of wounds is responsible for more cases of heartrot than all other injuries taken together. For this reason the protection of forests from fire is the most important preventive measure that can be taken to eradicate tree diseases. In fact, the best way of controlling diseases is by preventing them, and the Forest officers are endeavoring to eliminate any danger to the health of the forest, to prevent the injury of the trees, and to establish healthy conditions for their growth. This is forest hygiene, and it bears the same relation to the trees and forests as personal hygiene and community sanitation do to persons and communities.

It is impossible to grow a sound and thrifty forest for future generations if there are unhealthful conditions in the forest that are a constant menace to the trees. The first step in this hygienic work is close observation on the part of the Forest officers. 
The next important step is to prevent the infection and infestation of sound trees by getting rid of all diseased and insect-infested living and dying trees. By means of timber sales and free use, Forest officers very materially help in establishing healthy conditions on the National Forests. There is a clause in most timber sale contracts which requires the cutting by the purchaser of all snags and other unhealthy trees on the area. This measure not only eliminates undesirable trees from a hygienic standpoint, but it also makes it possible to utilize the merchantable timber left in undesirable trees, which would otherwise go to waste. On timber sales, Forest officers who do the marking leave for reproduction only such trees as are perfectly sound and healthy. Mistletoe infested trees, especially, are marked for cutting, for neither in plant nor in animal life can healthy offspring be expected to develop under unhealthful conditions.

Water Supply. Undoubtedly the greatest value of the mountain forests of the West, most of which are within the National Forests, lies in their influence upon the regularity of the water supply. In many States these mountains afford the only water supply for domestic use, for irrigation, and for the 


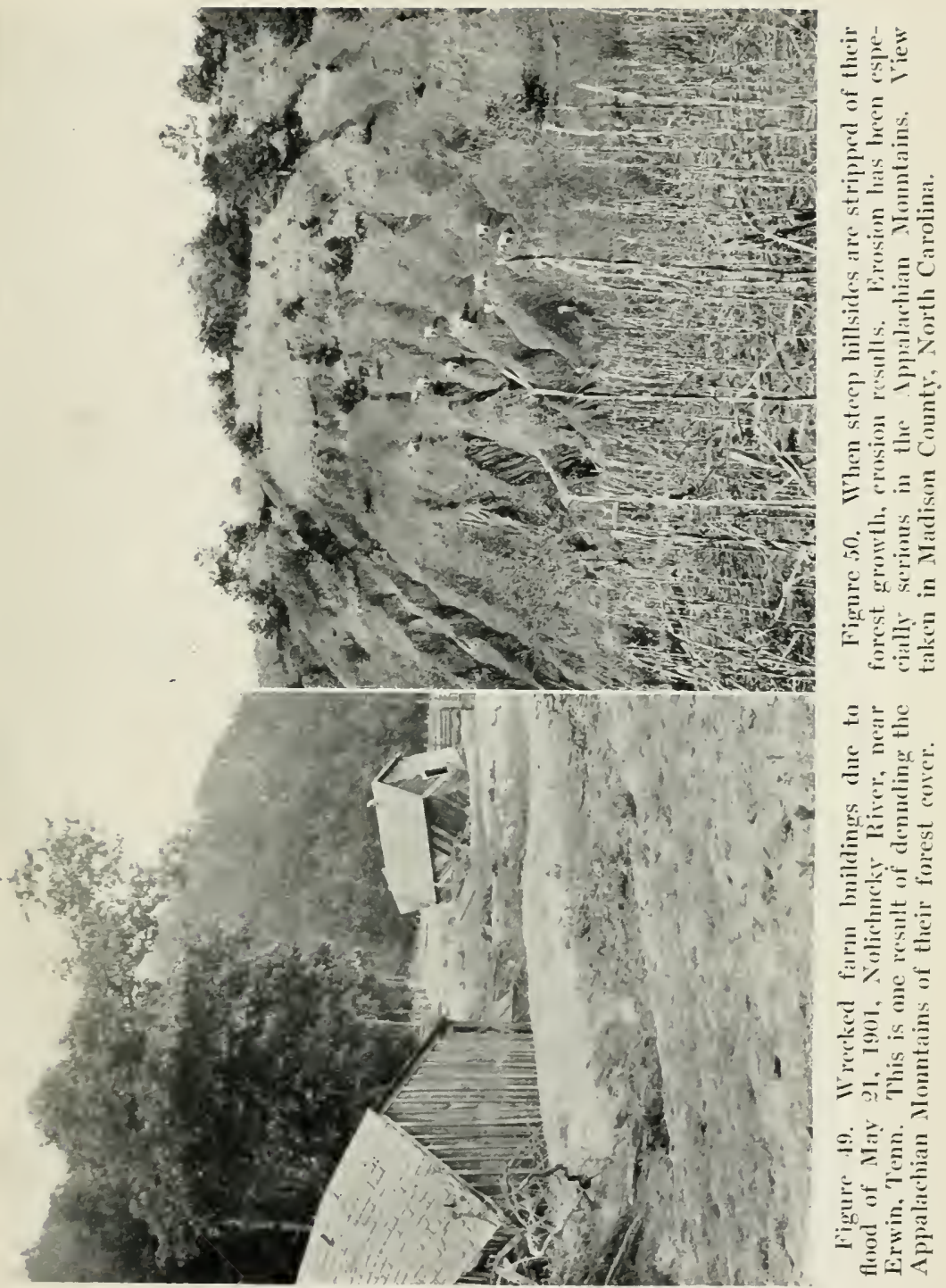



development of power. The future development of the entire region depends, therefore, upon a regular water supply. It is not so much the amount of water as the manner in which it flows from the mountains that is important. To insure this regularity, the vegetative covering is an important factor. For this reason, Congress made the preservation of conditions favorable to stream flow one of the principal objects in the establishment and administration of the National Forests.

Many of my readers who have lived out-of-doors a great deal have learned by common observation the simple problem of how the forest regulates stream flow. Any one who has been in a treeless region after a heavy rainstorm can recall how suddenly the streams swell and flood their banks, and how soon these same streams return to their former flow. On the other hand, a severe rainstorm in a forested region will hardly have an appreciable eff ect upon the streams. The difference is not very hard to explain. In a treeless region there are no natural obstacles which might delay or prevent the raindrops from reaching the ground. The soil is usually hard and dry, and the water runs off as though from a gable roof. In a forest, we well 


\section{4}

\section{OUR NATIONAL FORESTS}

know, the crowns of the trees intercept most of the rain that falls; very little strikes the ground directly. The rain that strikes the crown is dissipated on the leaves or needles, on the twigs and branches, and on the trunk. It must travel a long way before it reaches the ground, and all this delay helps in preventing a rapid run-off or flood. The soil in the forest is covered by a living ground cover of flowers, shrubs and young trees, and by a dead cover composed of leaves, twigs, dead branches, fallen trees, all of which interrupt the raindrop's journey to the ground. Even after the rain reaches the ground, only a small part of it goes off as surface run-off. The soil in the forest is loose and full of holes and channels made by decaying roots, earth worms, etc., so that the water is absorbed as fast as it reaches the soil. Also the soil in the forest contains a large amount of organic matter, resulting from decaying leaves and branches, and this organic matter acts as a great sponge, because it is capable of holding several times its own weight of water. As a result of the living and dead ground cover, the crown cover, and the organic matter in the soil, the rainfall is fed to the streams gradually through weeks and months, 


\section{PRO'TECTION}

instead of a few hours, and the nearby rivers have a steady, equable flow, instead of alternate stages of floods and low water.

Closely bound up with the protection of watersheds is the erosion problem. Without a forest cover, rain runs off mountain slopes very rapidly, often carrying with it silt and sand, and, in severe floods, even rocks and bowlders. A well known physical law states that the carrying capacity of a stream increases as the sixth power of its velocity. In other words, double the velocity of a stream and you have multiplied its carrying power by 64 ; increase its velocity ten times, and you multiply its carrying power by a million. The delay caused by the forest cover in each raindrop's journey down a mountain side not only prevents floods, but also preserves the fertility of the fields in the valleys below.

Many streams in the West carry such enormous amounts of silt that the storage capacity of reservoirs has been seriously impaired, even within a comparatively short time. Then, also, there is the added difficulty and expense of keeping the diversion works-the ditches and canals-free from an excess of this material. Studies which have been. 
carried on to determine in what way the administration of the National Forests can keep the destructive processes of erosion at a minimum have shown that the balance between the stability of the soil and rapid erosion on many slopes is so delicate that only a slight abuse may result in complete loss of the fertile top soil and permanent changes in the character of the vegetation.

In August, 1909, the town of Ephraim, on the Manti National Forest, Utah, experienced a disastrous flood from Ephraim canyon, which was attributed in part to the overgrazed condition on the watershed. An examination made the next spring clearly demonstrated that the severity of the flood was a direct result of deterioration of forest, brush, and grass cover, due to overgrazing during a long period of years. The canyon was therefore closed to grazing as an immediate protective measure. Plans were thereafter made to restore the forest cover of the canyon by planting.

In this kind of protection work, as in the case of forest fires, it has been found that preventive measures are much more effective and much less costly than remedial measures. The regulations under 


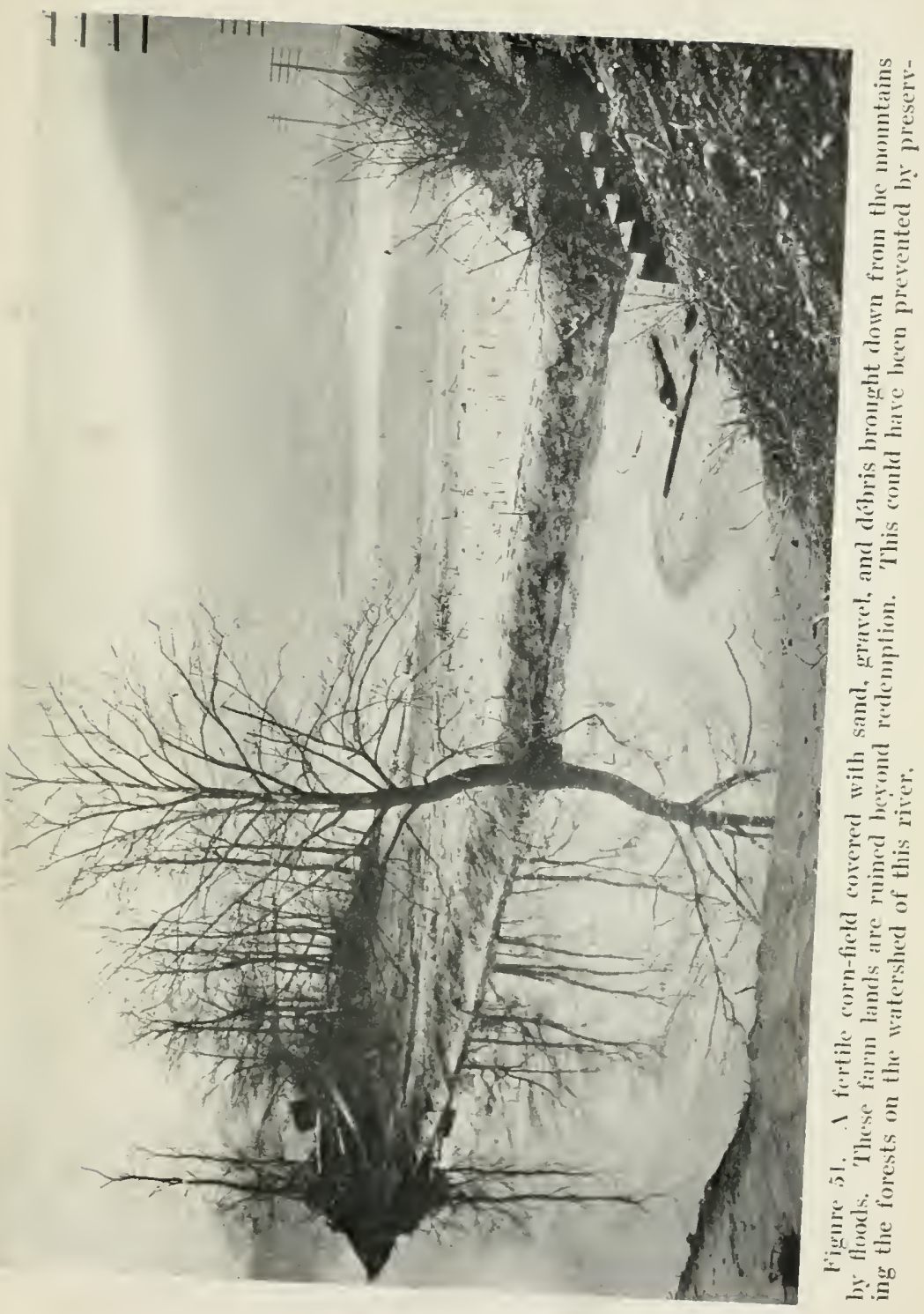



which the Forests are administered give the Secretary of Agriculture power to institute preventive measures. To insure the sufficiency and purity of the water supply of a municipality or of an irrigation district, or to prevent floods and snowslides, the use of watersheds for grazing, timber, special uses, or settlement is especially restricted when such restriction is found to be necessary. On steep grass or timber-covered mountain slopes both grazing and timber sales are prohibited, if necessary.

Public Health. From the relation which the National Forests bear to the streams that issue from them, it will be seen that they may exert a great influence, upon the health and general welfare of the communities in the valleys below. All persons either permanently or temporarily camped upon National Forest land are liable to trespass proceedings if unsanitary conditions result from their presence. All camp refuse must be disposed of either by burying or burning. This regulation applies to hunting and fishing parties, as well as to large logging camps, sawmills, and construction camps on National Forest lands. Thus the regulations strictly guard against the pollution of the 
water supply of the people who live in the large towns and cities, and also those who live on the Forests or near them. The watersheds tributary to many of the large western cities and towns are under special protection by the Forest Service. Under this sanitary regulation, it is possible to maintain such control of them as will greatly reduce the danger of typhoid and other enteric diseases.

Violation of Game Lares. Wild game, fish and birds add materially to the enjoyment of the $\mathrm{Na}$ tional Forests by the public, and their protection and preservation is a duty of Forest officers. Although this duty rests primarily with the State the Forest Service assists, as far as practicable, in the protection of game on the National Forests from illegal practices. Forest Service officials are at the same time State Game Wardens. In the event of a violation of the state game laws, they either apprehend the offender or report the matter to the proper state official.

Various kinds of game and bird refuges may be included within National Forests, depending upon whether they are created by specific acts of the State Legislature or by Acts of Congress. In these refuges, hunting, trapping, willfully disturb- 


\section{PROTECTION}

ing, or killing any game or bird is prohibited. Whether the violation occurs in the state game refuge or the national refuge, the Forest officer has authority to arrest the offender without warrant. 


\section{CHAPTER IV}

\section{THE SALE AND RENTAL OF NATIONAL FOREST RESOURCES}

The timber, the pasture, the water and mineral resources and the land in the National Forests are for the use of the people, and they may be obtained for legitimate use from the local Forest officers without delay. In fact, the Forest Service is doing all it can to encourage all kinds of business which depends upon National Forest resources.

THE SALE AND DISPOSAL OF NATIONAL FOREST TIMBER

There has been a steady increase in the amount and value of the timber cut on the National Forests. During the fiscal year 1917 over 700,000,000 feet of timber, valued at almost $\$ 1,500,000$, was cut, while almost three times as much was sold. Most of this was cut in the States of Montana, Oregon, Idaho, Washington, California and Arizona.

All mature timber on the National Forests which 170 
may be cut with benefit and in accordance with certain well-established forestry principles, is for sale and is advertised and offered as demand arises. The outstanding feature of government timber sales is the fact that only the stumpage is sold, the title of the land remaining with the Government. The timber is sold in any quantity, so long as the sale is in accordance with well-established policy. Large sales require a large initial investment for constructing a railroad or other means for taking out the timber, and may even require the construction of a common carrier from the market to comparatively inaccessible regions.

Government Timber Sale Policy. The National Forest timber sale policy, first of all, aims to prevent the loss of this valuable public property through forest fires. This phase of the policy, however, is covered under the chapter on protection. Next, it aims to utilize the ripe timber which can be marketed and to cut it in such a way as to insure the restocking of the land with young timber and the continuance of forest production. The price at which timber is sold represents, as required by statute, the appraised market value and a proper return to the public which owns it. It is disposed 
of in such a way as to prevent its speculative acquisition and holding, and to prevent monopoly.

National Forest timber has found its way into both the general, far distant market, and the local market. But it is the aim of the Forest Service to first of all provide for the requirements of local communities and industries, including the free use and sale at cost to settlers as authorized by statute. It is also the aim of the Forest Service policy to make timberlands of agricultural value available for settlement under conditions which prevent speculative acquisition but encourage permanent and genuine farming. According to this policy, land which at the present time is covered with a good stand of timber and which has been shown to have a greater value for agricultural purposes is cleared as soon as a bona fide sale can be consummated. And, lastly, it is the aim of this policy to return as soon as possible the cost of protection and administration of the National Forests, and to yield a revenue to the States, since these are entitled by statute to 25 per cent. of all gross receipts as an offset to the loss of local taxes through the government ownership of the forests.

Annual Yield and Cut. Each year the amount 


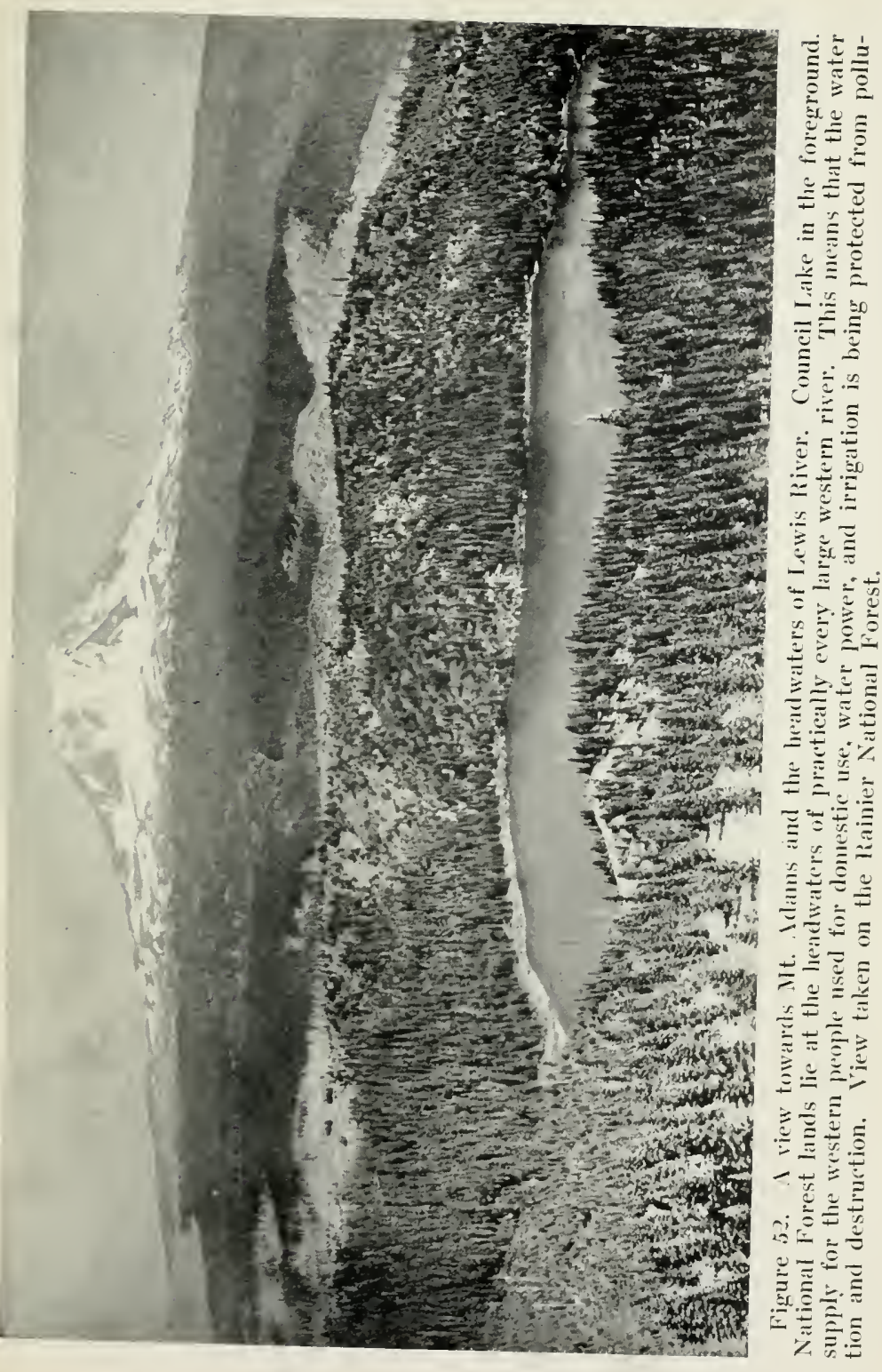



of timber which can be cut from each National Forest, according to sound forestry principles, is authorized by the Secretary of Agriculture. This cut is based upon the best available data as to the amount of mature and over-mature timber needing removal, and the amount of annual growth on each Forest. At the present time only a small percentage of the authorized annual cut of the Forests is taken. Most Forests cut a very small part of their annual allotment, but a few Forests cut their full annual yield, or nearly so. On some Forests, the entire annual yield is used by local industries and no timber can be sent to the general market; on others a very small part of the annual yield is used by local needs and most of the cut can be sent to the general market. On the Cascade National Forest, in Oregon, for instance, the annual production is estimated at about $200,000,000$ feet, while the present local needs can be supplied by approximately 1,000,000 feet. From such a Forest a large annual cut can be made for the general market. On the Deerlodge National Forest, in Montana, on the other hand, the annual yield is estimated to be about 40,000,000 feet, all of which is needed to supply the large copper mines near Butte. 


\section{OUR NATIONAL FORESTS}

From Forests like this, no sales for the general market can be made.

Although the National Forests contain about six hundred billions of board feet of timber, or about one-fifth of the standing timber in the United States, only a small fraction of the available timber is actually disposed of. This is due to the comparative inaccessibility of this timber and the presence of large bodies of privately owned timber which lie between it and the market. The result of this condition is that the bulk of the salable timber on the Forests will be automatically saved until such a time when most of the privately owned timber has been cut. In this way, future generations will benefit and the public will receive a much better price for it years hence than they could possibly obtain now.

Timber Reconnoissance. Before any timber can be sold to advantage, however, it is necessary to take an inventory of the timber resources. In other words, it is necessary to know where the timber is, how much there is, and what can be done with it. This timber estimate, or timber reconnoissance, as it is called, is also needed to settle questions of title 


\section{NATIONAL FOREST RESOURCES 175}

arising from the presence of patented lands or valid claims; to determine if cutting is advisable on a given area, and, if so, under what stipulations; and to fix the minimum price at which stumpage is to be sold. The annual yield, or the amount of timber grown or produced annually upon an area, must be the ultimate basis of the annual cut, and this yield can only be computed after an inventory of the timber has been made.

Timber reconnoissance (valuation survey or valuation strips) involves an estimate of the standing timber by small legal or natural subdivisions of land, with the necessary land surveys, the preparation of an accurate topographic and forest type map, and the compilation of detailed descriptive notes. These notes deal with the condition and character of the timber, the most practical methods of exploitation, the extent and character of the young growth, and many other factors which affect the management of timber lands. These data are secured at a cost of from 3 to 10 cents per acre, depending upon the accessibility and the topography of the region and the density of the timber. This work is carried on both in the summer and in the 
winter. Up to date, about $21,000,000$ acres have been covered by intensive reconnoissance and about $48,000,000$ acres by extensive methods.

Logging the Timber. In order that my reader may better understand various matters connected with the disposal of National Forest timber, it will be necessary to give a brief outline of how timber and other forest products are taken from the woods, and the different steps necessary before a green tree in the woods becomes a board or a railroad tie.

The methods of logging used in the National Forests are essentially the same as those used on private lands, with the exception of certain details, such as the protection of young growth, the cutting of snags, and the disposal of the brush. The methods used, of course, vary with the locality; they are different for the Pacific Coast, where donkey engines are used, than for the Rocky Mountains, where horses are largely employed. They vary with the climate, the topography, the size of the timber, and the kind of product to be harvested. But a typical logging operation, as carried on in the Sierras of California, will give an idea of how logs are taken from the forest.

In the particular operation which I have in mind 


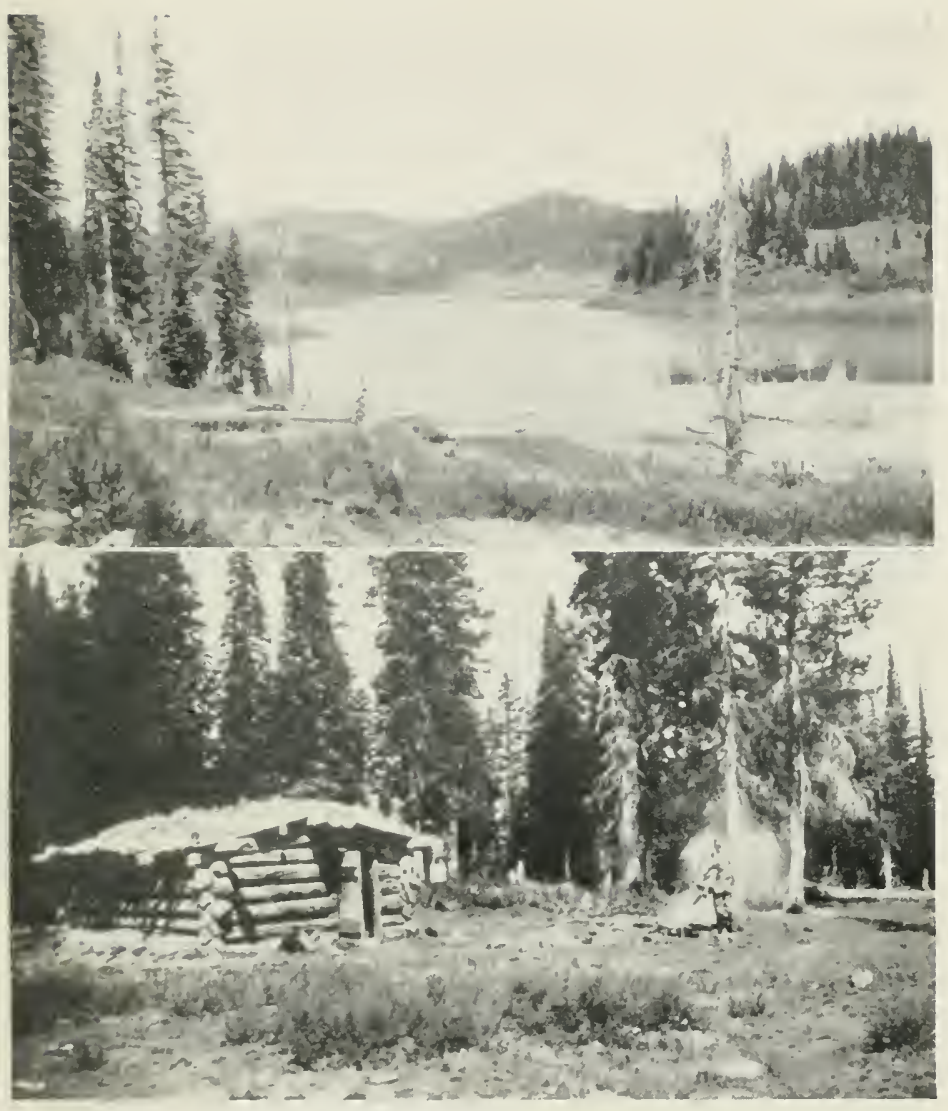

Figure 53. A large storage reservoir used to irrigate the ranches in the valley below. Elevation 10,500 feet. Battlement National Forest, Colorado. Photo by the author.

Figure 54. A sheep herder's camp used temporarily ly Forest Service timber cruisers. Elevation about 10,000 feet. Battlement National Forest, Culorado. Photo by the author. 

the timber was located on the western slope of the mountains between 3,500 and 5,000 feet in elevation. The slopes were of medium steepness and much of the timber was on level benches. The large sawmill was located at the lower edge of the timber and the logging camp was in the woods near the cutting. The felling of the trees, which were from 3 to 6 feet in diameter, was done by two men with a two-man saw. These men are the "fallers." Two men then cut the tree into logs and still other men called "swampers" cut the brush and fallen trees away so that the newly cut timber can be "skidded" to the railroad. This "skidding" is done by a powerful, steam-driven stationary donkeyengine, which is fitted up with a long cable and a drum. After the $\log$ is attached to the cable out in the woods by means of a "choker," the man in the woods gives the signal and the engine starts, revolving the drum and winding up the cable at the same time pulling the log towards the engine. Just beside this engine is a platform from which the logs are loaded directly on flat cars. When six or eight flat cars are loaded in this manner a locomotive hauls them to the sawmill where they are sawed into boards. In this case as soon as the 
boards were cut they were placed in a flume in which there was a strong stream of water. In this they floated about 40 miles to a town in the valley below directly into the company's lumber yard.

In the Rocky Mountains one of the main forest products derived from the National Forests is railroad ties. On the particular operation with which the writer is familiar the Government had sold to a tie operator about 3,000,000 railroad ties under a long term contract. This tie operator had a large contract with a railroad company. The area of the sale, several thousand acres, was divided or surveyed into long strips each 100 to 150 feet wide and from one to one and a half miles long. A large camp and commissary was established on the area. There were about 100 tie choppers and each man was assigned to a strip. On these strips the trees to be cut were marked by a Forest officer. Trees too small to make ties were left as a basis for a future tie operation in from forty to fifty years.

The tie choppers usually worked alone. They first felled the tree with a saw, cut the lower limbs off, and marked off the ties on the bark to see how many ties could be cut from the tree. The tree was then "scored" with an ax on both sides in order 


\section{NATIONAL FOREST RESOURCES 179}

to start making the two flat faces of the tie. These sides were then chipped with a "broad ax," thus making two smooth faces. The bark was then peeled from the other two faces and the tree was then cut into finished ties. After the ties were made the top of the tree was lopped, that is, the branches were cut from the trunk. In this operation these branches were scattered evenly over the ground. 'The tie chopper then cleared a road through the middle of his strip and "parked" his ties on the road. He then stamped his private mark on each tie. In the winter the ties were "hauled" on large sleds to the river bank. Each tie chopper's ties were put in a separate pile so that the company's scaler could count them and credit them to the man that made them. In the spring, when the river's banks were full, the ties were "driven" down the river to the shipping point, usually a town on a railroad line.

A Forest officer is detailed to an operation of this kind to inspect the choppers' work and count and stamp the ties. He sees to it that all trees that have been marked for cutting are cut, that no trees not marked have been cut, that young growth is not unnecessarily injured, that the stumps are not 
left too high, that the tops are fully utilized, that the slashing or brush is disposed of according to the contract, and that the operator is keeping all his agreements in the contract.

The First Step in Purchasing Government Timber. After the desired body of timber has been located, the first step for any one desiring to purchase government timber is to communicate with an officer of the National Forest in which the timber is located. If only a small amount is desiredless than $\$ 50$ in value-the local Ranger can arrange to make the sale without delay. Amounts valued at more than this can be sold only by the higher officials of the Service, that is the Supervisor, District Forester, or the Forester, according to the size of the sale. The Supervisor can sell up to two million feet; larger sales are made by the District Forester or the Forester. All sales exceeding $\$ 100$ in amount must be advertised, except those made to homestead settlers and farmers in a private sale. Sales are advertised in order to secure the largest number of bidders possible and thus prevent the monopoly of large bodies of timber by large timber operators.

Procedure in an Advertised Sale. After the ap- 

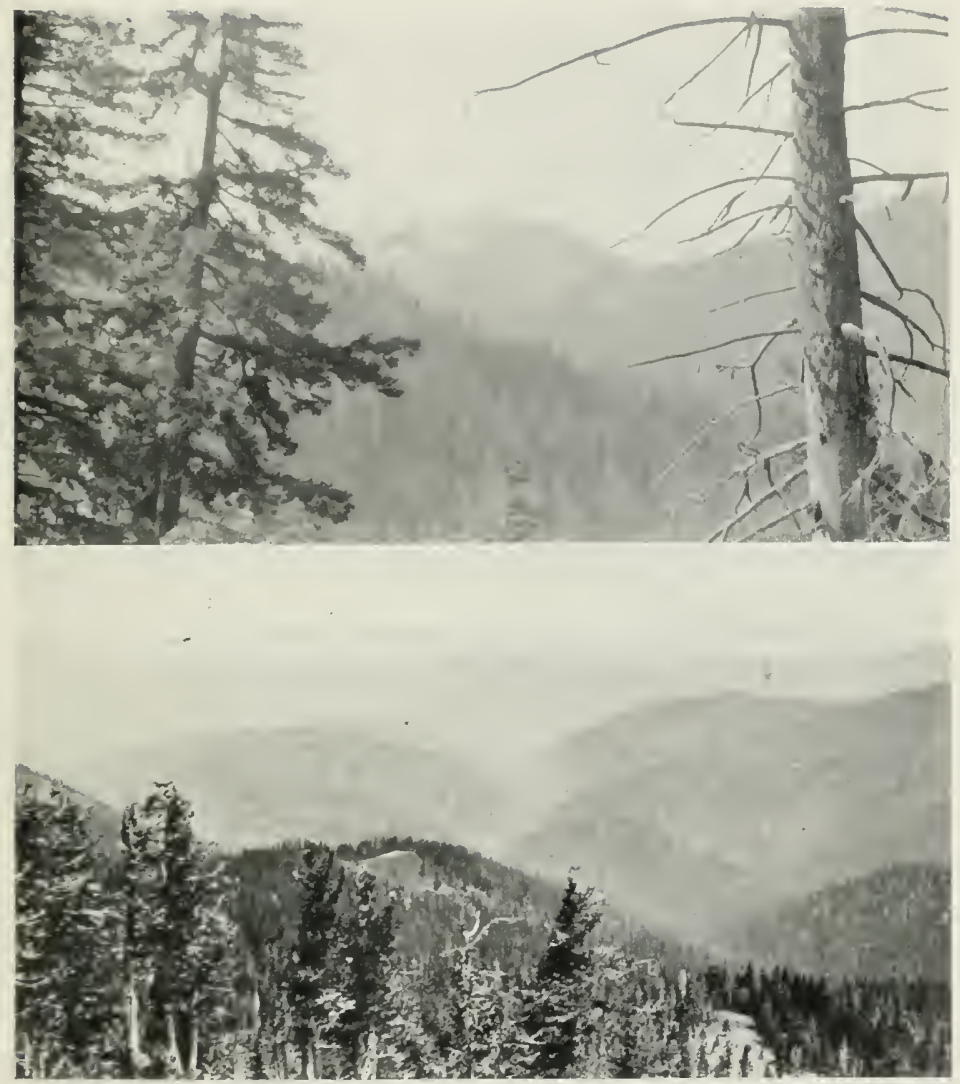

Figure 5.). View taken in the Coast liange mountains of Califormia where Sugar pine and Douglas fir are the principal trees. Klamath National Forest, California. Photo by the author.

Figure 56. A typical mountain scene in the California Coast Range. On these steep slopes a forest eover is of vital inportance. Klamath National Forest, California. Photo by the aunor. 

plicant has selected the body of timber he wishes to purchase, he is furnished by the Supervisor with a sample application stating the area, estimated amount, minimum stumpage price, period allowed for cutting and removing the timber, and other conditions to be complied with, following as closely as possible the form of the final sale agreement. Usually, also, the purchaser is interested in the amount of timber which he may cut per acre. For this reason he visits sample areas on which the trees have been marked for cutting. A notice of the sale of the timber is then published, the choice of mediums and number of insertions depending upon whether the sale is of local, regional, or general interest. 'This notice describes the timber, gives the minimum stumpage prices that will be accepted, and specifies the date upon which sealed bids will be received. The period of advertising is at least 30 days, and in large sales from 3 to 6 months. Forms for bidding are furnished to the original applicant and others who signify their intention to bid. A deposit is required with all bids to show the good faith of the bidder. In large transactions this deposit is usually from 3 to 5 per cent. of the purchase price. On the date specified in the adver- 
tisement the Supervisor (or District Forester) opens all bids received and awards the sale to the highest bidder. The sale contract is then prepared and executed by the purchaser.

A specific statement of financial ability is required in all sales of ten million feet or more, and in smaller sales in the discretion of the approving officer. Such a statement may be required before the approval of the sale application, either formal or tentative, and in any event before the timber is awarded to the successful bidder. The contract must be supported by a suitable bond given by two responsible sureties or by a surety company authorized to do business with the United States.

Timber Sale Contract Clauses. The sale contract contains in full all the conditions under which the cutting is to be done. In all sales of National Forest stumpage the contract provides that no timber shall be cut until it has been paid for, and that it shall not be removed until it has been scaled by a Forest officer. All live timber is marked or otherwise designated before cutting, and any merchantable timber used for logging improvements, such as houses, bridges, stables, etc., must be scaled and paid for. In order to secure full utilization of the 


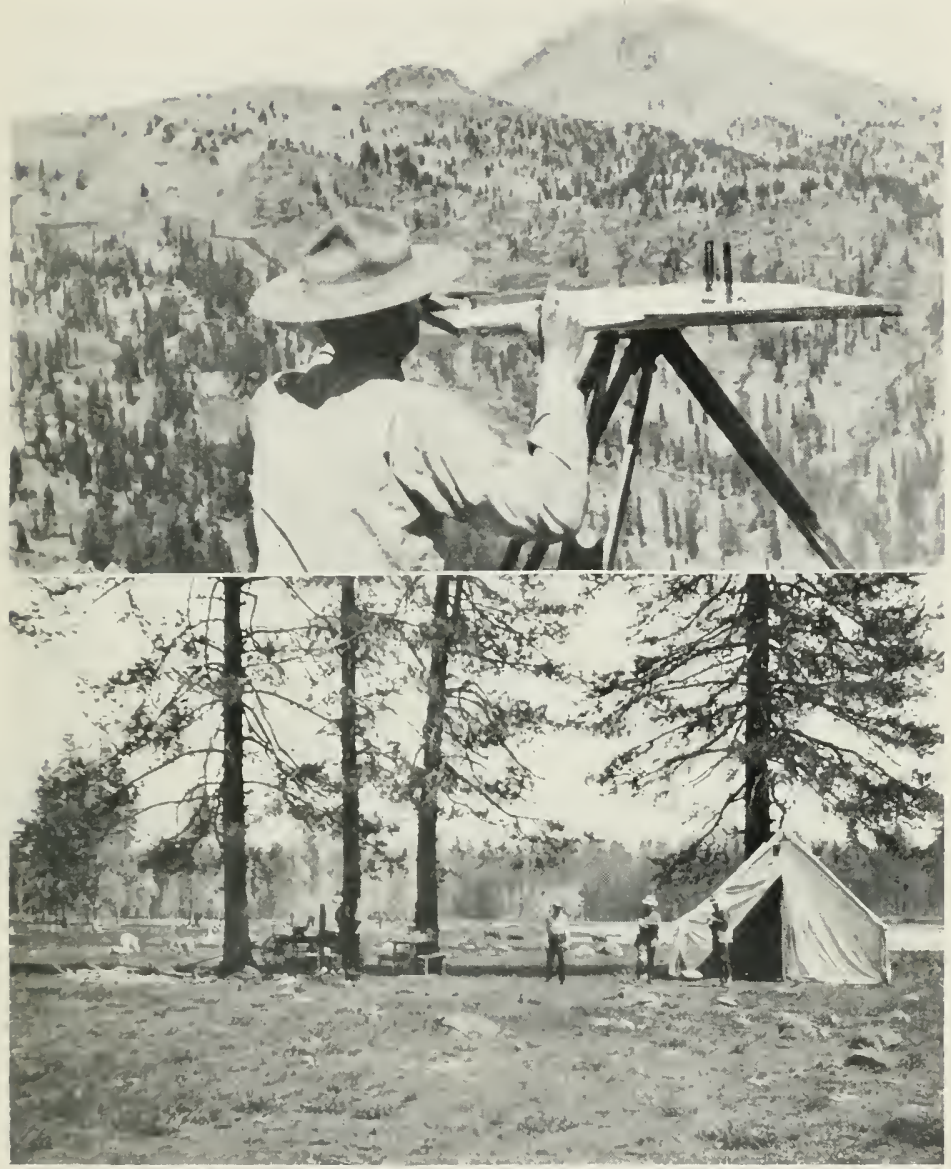

Fignre 5i. I forest officer at work on a high mountain peak making a plane-table survey and timber estimate of National Forest lands. Photo by the author.

Figure 5s. I government timber cruiser's summer camp. These cruisers gret a fairly accurate estimate of Uncle Sam's timber resources at a cost of from 2 to 5 cents an acre. Photo by the author. 



\section{NATIONAL FOREST RESOURCES 183}

timber the maximum stump height is ordinarily fixed at 18 inches, and merchantable timber must be used to a specified diameter in the tops, which is adjusted for each species in accordance with local manufacturing and market conditions. The officer in charge of the sale is authorized to vary the stump height and top diameter in individual cases when those specified in the contract are not practicable. The tops must be trimmed up and, as a rule, brush must be piled and burned, or burned without piling under the direction of Forest officers. Merchantable timber which is not cut and removed and unmarked trees which are cut must be paid for at double the specified stumpage rates. This extra charge serves as a penalty.

All camps, buildings, railroads, and other improvements necessary in logging and manufacturing the timber may be constructed upon National Forest land without charge. Railroads which open up inaccessible regions may be required to be made common carriers or to transport logs and lumber for other purchasers or for the Government at reasonable rates.

Since fire protection is one of the most important duties of the Forest Service, provision is made in 
all contracts that the purchaser must place himself and employees, as well as the employees of his contractors, at the disposal of authorized Forest officers for fighting fires. Reimbursement is made for such services at the wages in vogue for fighting fires on the National Forest in question, unless the fire threatens the timber of the purchaser or property of the operator, or is started in connection with the operation. Under these conditions the purchaser is expected to furnish his available employees to assist the Government in fire fighting without charge. Efficient spark arresters are required on wood and coal burning boilers or locomotives. Inflammable material must be cleaned up in the vicinity of logging engines, and other precautions taken to insure against fire spreading from this source. Snags and diseased trees upon the sale area must usually be felled, whether merchantable or not, in order to remove fire menace and to check the spread of timber infestations and pests.

Special Contract Clauses. Special clauses are inserted in contracts to meet peculiar and unusual conditions. These deal with the number of men the company is to furnish for brush burning; the time of the year this work is to be done; the con- 

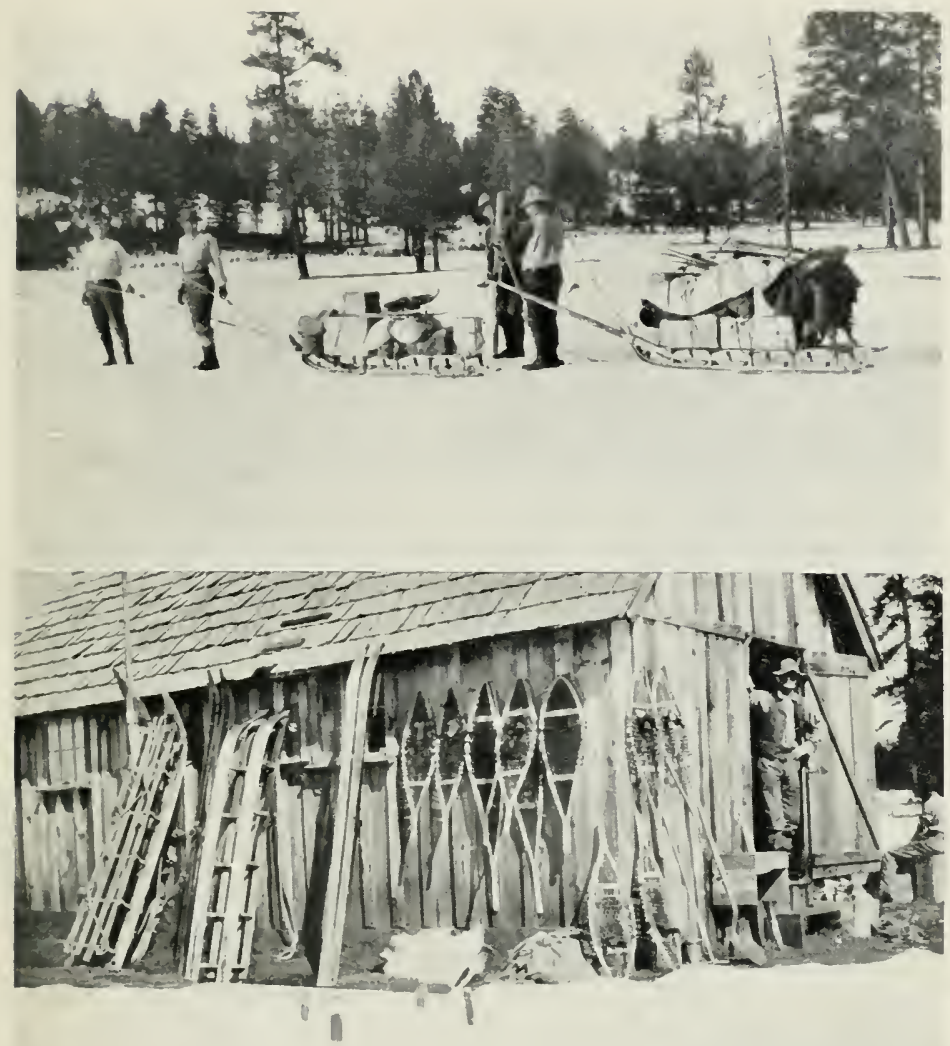

Figure 59. Forest officers moving camp while engaged in winter reconnaissance work. All food, heds, and clothing are packed on ".laska" sleds and drawn by the men themselves. Photo by the author.

Figure 60. A winter reconnaissance camp showing snow-shoes, skis, "Alaska" sleds, and bull hide used to repair the webbing on the snow-shoes. Lassen National Forest, California. Photo by the author. 

struction of fire lines; the manner of scaling timber; the manner of piling and the location of piles of material to be scaled; the definition of a merchantable $\log$; the utilization of tops; the manner or method of logging to be used; the location of improvements; the use of timber for the construction of improvements; the disposal of improvements at the termination of the contract; where cutting is to begin and how fast it is to proceed; the percentage of merchantable timber to be reserved in marking; and other special clauses recommended by the $\mathrm{Bu}$ reau of Entomology for the sale of insect infested timber.

That the Forest Service timber sale policy and the various timber sale clauses have met with the approval of the lumbermen and the timber buyers of the Western States is attested by the fact that in the last ten years (from July 1, 1907, to June 30, 1917) there have been nearly 75,000 purchasers of National Forest timber and that between these two dates the annual number of timber sales has increased from 5,062 in the fiscal year 1908 to 11,608 in the fiscal year 1917. No better evidence could ke cited of the confidence which the lumbermen have in the Forest Service method of doing business. 
When the Operation May Begin. As soon as the contract has been executed and the first payment has been made a portion of the timber is marked for cutting and the purchaser may begin operations at once. Sometimes cutting in advance of the execution of the contract is allowed to prevent serious hardship and unnecessary delay and expense on the part of the purchaser.

Marking the Timber for Cutting. In order to insure a proper restocking of the ground, all live trees must be marked or otherwise designated by a Forest officer before cutting can commence. Usually from $1 / 10$ to $1 / 3$ of the stand is reserved, either scattered over the entire tract or distributed in groups. These trees are left for various reasons, depending upon circumstances. The most important consideration is, of course, to leave enough seed trees to restock the cut-over area. On steep slopes a certain number of trees must be left to protect the watershed and to prevent the erosion of the soil. Many species of trees are subject to windthrow when the stand is thinned out. To counteract this tendency a sufficient number of trees must be left to prevent the wind from getting an unobstructed sweep. In many semi-arid por- 


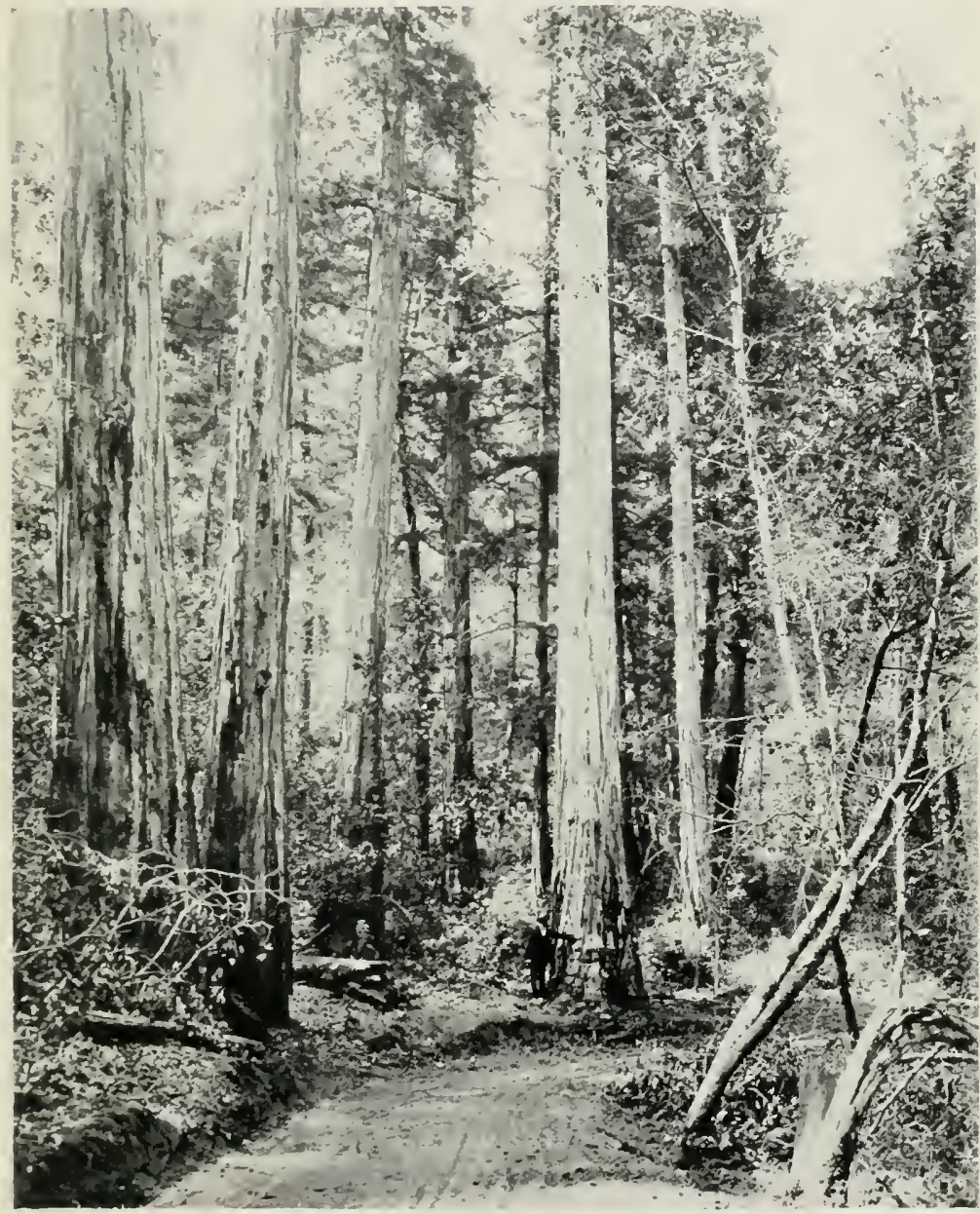

Figure 61. A group of giant redwoods. Santa Cruz County, California 


\section{NATIONAL FOREST RESOURCES 187}

tions of the West additional trees must be left standing to protect the forest from excessive drying and to prevent the ground from being occupied by useless tree weeds and brush. Often, especially along highways, trees are left for their scenic effect. From an economic standpoint it is important sometimes to leave trees in order to make a second cut worth while.

Where only dead timber is purchased, and no living trees are cut, or where patches of forest are to be cut clean, Forest officers, instead of marking every tree to be removed, blaze and mark a boundary of the cutting area or patch and instruct the purchaser accordingly. Where individual trees are marked they are blazed and stamped "U. S." next to the ground on the lowest side of the stump. Additional blazes may be made several feet above the ground whenever desired by the purchaser for the convenience of his "fallers" or where deep snow may conceal the lower mark from the "fallers." Where both kinds of blazes are used, one man, in fairly dense pine timber, can mark from 500 to 1,000 trees in a day. Under no condition may unmarked or undesignated trees be cut by the purchaser. 
The system of marking and the proportion of the timber to be cut is explained to purchasers by marking sample areas before the contract is executed. The cost of logging under the methods of marking adopted is compensated fully in the stumpage appraisal.

Scaling, Measuring, and Stamping. Unless timber is sold by estimate, it must be scaled, counted, or measured before it is removed from the cutting area or place agreed upon for this purpose. In addition it must be stamped by a Forest officer with a regulation marking ax or similar instrument. Payment is made upon the actual scale, count or measure, with due allowance for defect.

All National Forest timber is sold under specifications which are in accordance with those in commercial use, such as logs by the thousand board feet, ties by the piece, poles by length and top diameter, shingle bolts by the cord, and mining timbers by the linear foot. All logs are scaled at the small end.

All saw timber is scaled by the Scribner Decimal $\mathrm{C}$ log rule. In order to permit scaling at reasonable cost to the Forest Service, purchasers may be required, where the cost of logging may not be 


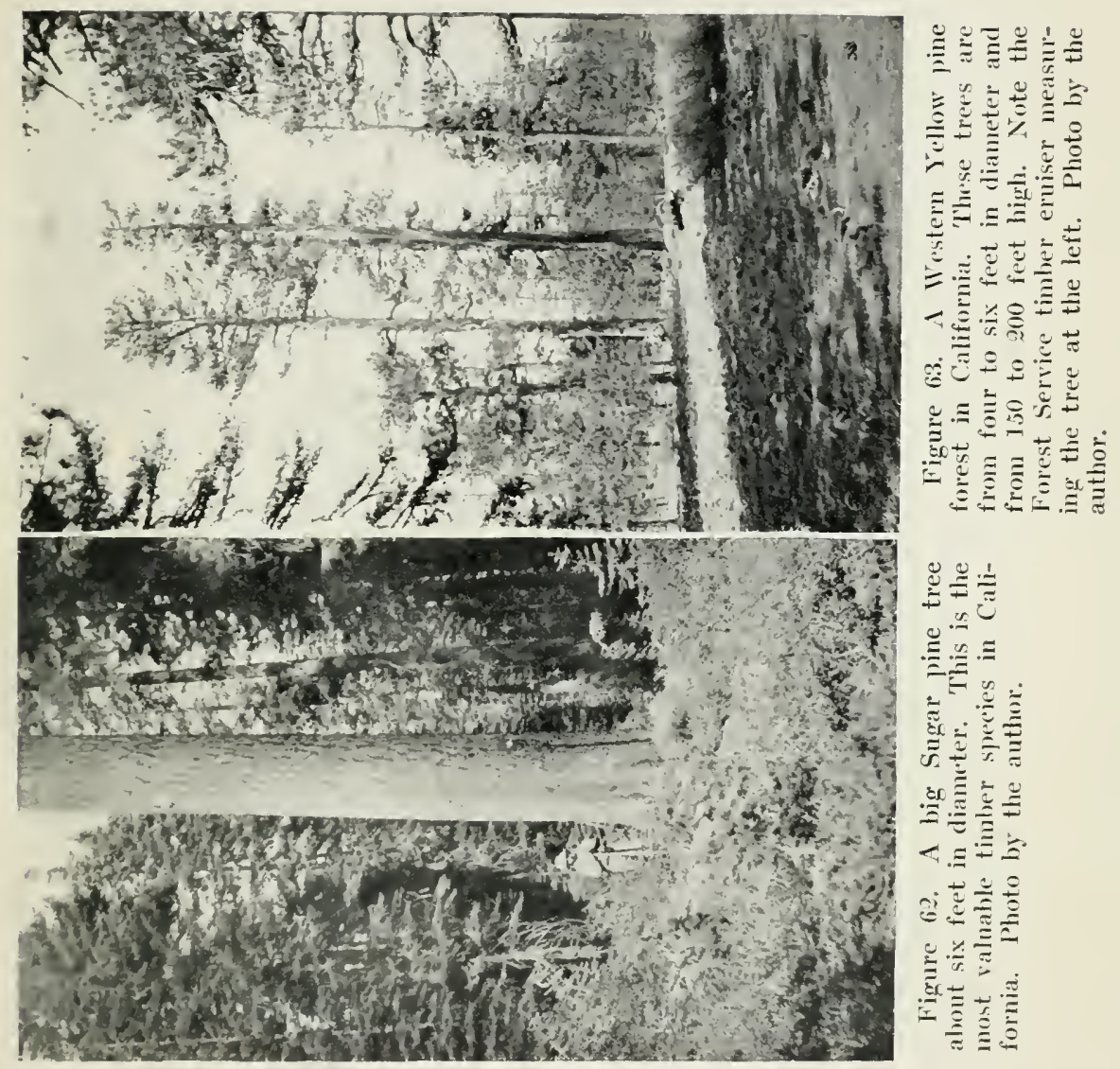



unduly increased, to skid and pile the logs for scaling. Piles and skidways must be constructed so as to permit economical scaling and when necessary and practicable the purchaser is required to mark the small ends of the logs to avoid misunderstanding when they are scaled on the pile.

Logs or other material that has been scaled or measured are designated by a "US" stamp impressed in the wood so that the material may not be scaled again by mistake. Each merchantable log scaled is stamped on at least one end and unmerchantable or defective logs are stamped "US" in a circle. Material other than saw logs, such as mine timber, ties, posts, poles, or piling, after scaling, is stamped on at least one end. Cord wood is stamped at both the top and bottom of each rick.

On all National Forests except those in Alaska and west of the summit of the Cascades in Washington and Oregon, logs over 16 feet are scaled as two or more logs as far as practicable in lengths of not less than 12 feet. In Alaska and parts of Oregon and Washington logs up to and including 32 feet in length are scaled as one log; logs from 32 to 64 feet inclusive are scaled as two logs as nearly equal in length as possible in even feet. All 
diameters are measured inside the bark at the top end of the log and diameters are rounded off to the nearest inch above or below the actual diameter.

In the case of logs each one is numbered and the number entered in a scale book with the corresponding board foot scale of the log. In the case of ties, posts, poles, mining timbers, etc., each pile or skidway is numbered and the count or scale entered opposite the corresponding number in the scale book.

Disposal of Slash. One of the most important features in National Forest timber sales is the disposal of the brush or slash after logging. On account of the great diversity of conditions which obtain on the Forests, the best way to dispose of brush is not everywhere the same. Piling and burning is required where the fire risk is great; otherwise the method promising the best silvicultural results is used.

When piling and burning is necessary, all tops and débris, including large chips made from hewing ties, are piled at a safe distance from standing trees. The piles are not allowed to be made in groups of seedlings or young growth, against dead snags, near living trees, or on stumps, large tops or logs, but 


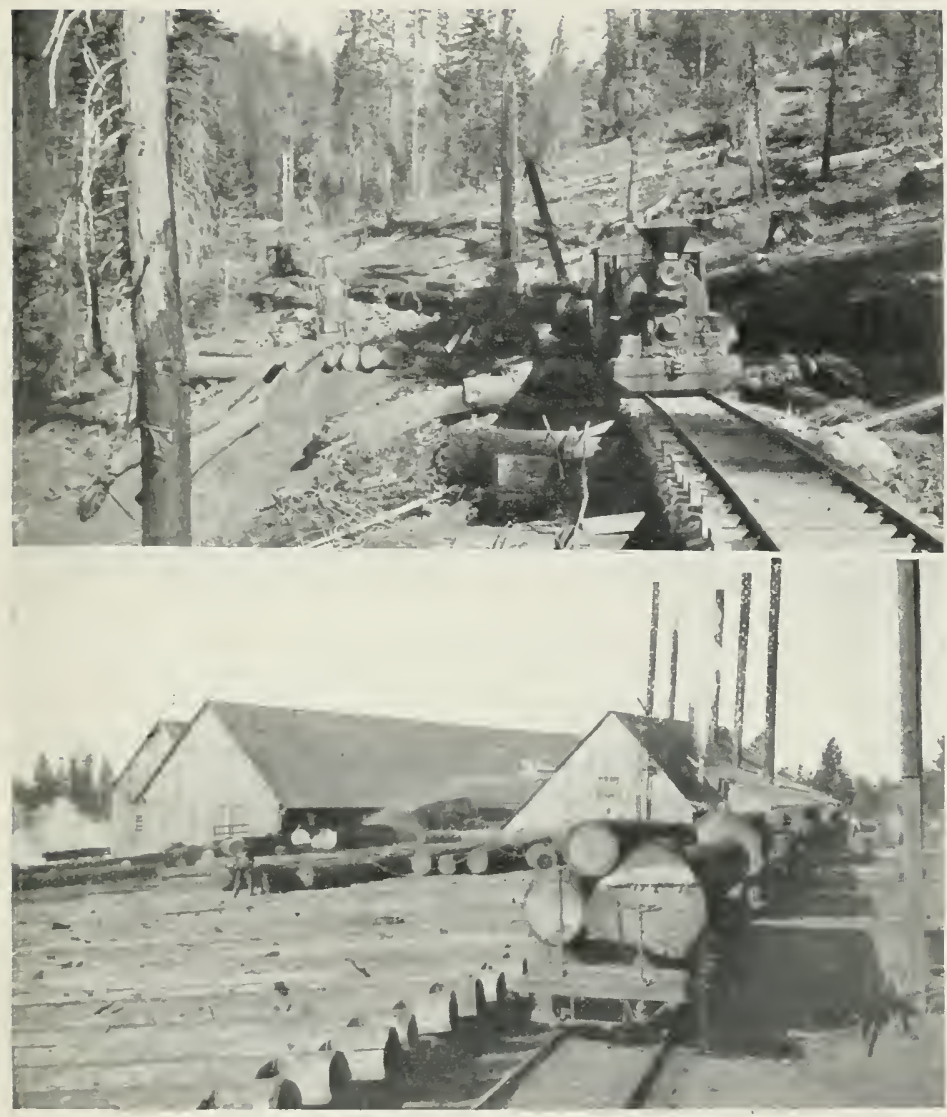

Figure 61. Logging in California. Powerful steam engines pull the logs from the woods to the railuad and load them on flat cars. Photo by the author.

Figure 65. The loaded flat cars reach the saw-mill where the logs are unloaded and sawn into lumber. During the fiscal rear $191 \mathrm{i}$ timber sales on the National Forests bought into the National Treasury almost \$1.700,000.00. Photo by the author. 

wherever possible in openings. The piles are adapted to the size of the opening in which they are made and must be made sufficiently compact to kindle easily and burn cleanly. The ideal pile is of medium size, conical in shape, compact, from 5 to 7 feet in diameter at the base and from 4 to 5 feet high. Brush piling and burning is an art which can only be acquired after long experience.

Brush is scattered whenever this method promises the best silvicultural results, unless there is serious danger from fire on account of dense timber and reproduction. The scattered brush is intended to afford protection to seedlings from excessive transpiration and from trampling by stock and to protect the soil from erosion.

Ground burning may be advisable where clean cutting has been employed, to expose the loose mineral soil for better seed germination. When this method is used the purchaser is required to clear a fire line around the area to be burned and to furnish adequate help to the Forest officer who supervises the burning.

Frequently brush is burned as the cutting progresses. Fires are started at convenient points and the brush is thrown on them as it is lopped. 
Where brush burning is necessary it is not advisable, ordinarily, to burn over an entire sale area. It is frequently possible to burn the brush so as to form broad fire lines, particularly along railroads or wagon roads. The best times for brush burning are after a light fall of snow or rain, early in the spring before the snow has melted or the dry season has begun or during or immediately after summer rains. Brush disposal must always keep pace with logging except when the depth of snow or other reasons make proper disposal impossible. Often the brush must lay in piles at least one season before it becomes dry enough to burn.

Payment for Timber. Payment must be made for all timber in advance of cutting. This, however, does not imply that one advance payment must be made to cover the stumpage value of all the timber included in the sale. Frequent installments are allowed sufficient usually to cover the cut of one or two months.

This arrangement makes it possible to secure large tracts of National Forest timber at a very slight initial outlay and to hold them with almost no interest charges. The other usual carrying charges, namely, taxes and fire protection, are elim- 


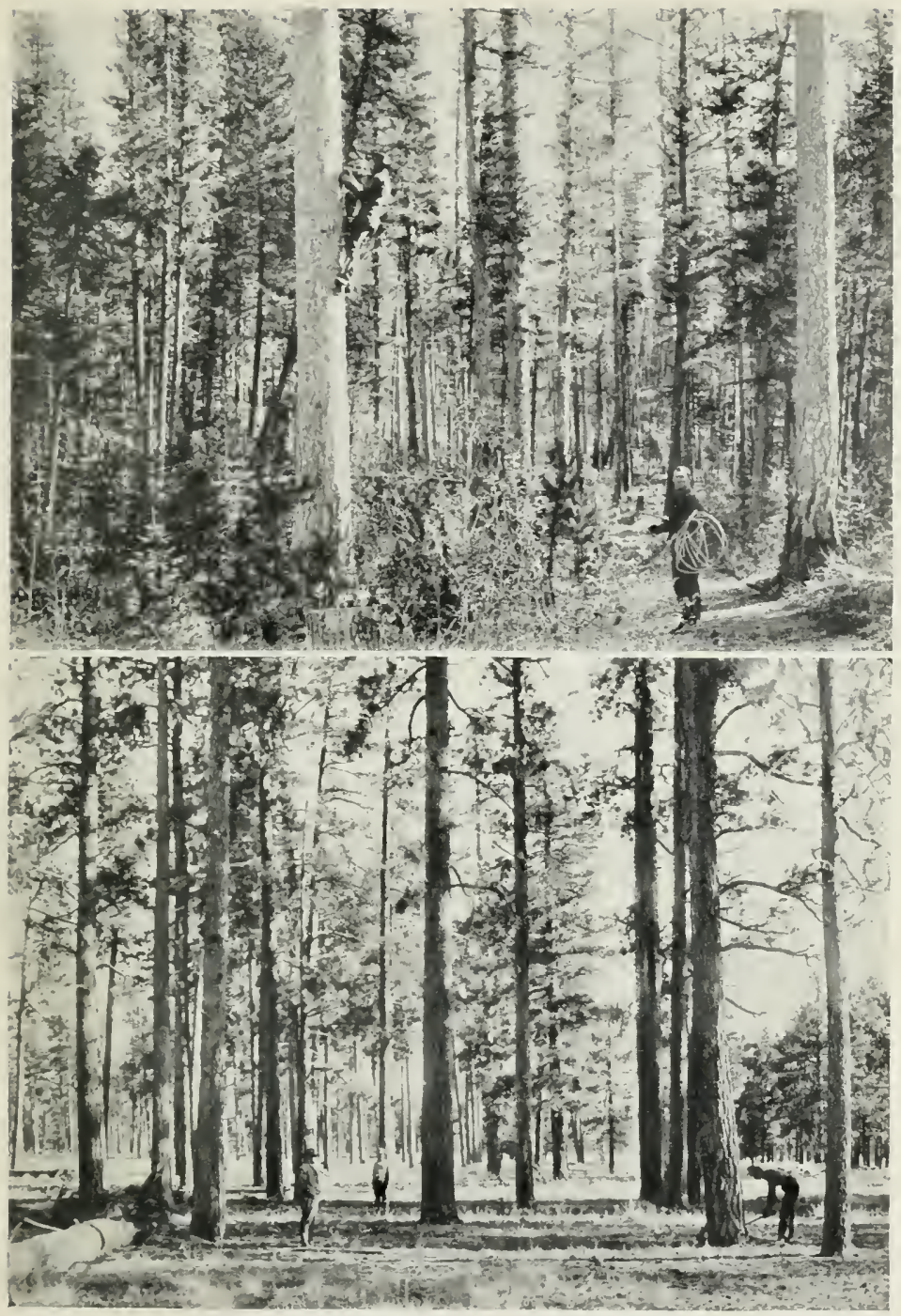

Figure 66. Scene in Montana. Forest officers constructing a telephone line through the Flathead National Forest.

Figure 6\%. Forest Ranger, accompanied by a lumberman, marking Vational Forest timber for cutting in a timber sale. Coconino $\mathrm{V}_{\mathrm{a}}$ tional Forest, Arizona. 

inated. The timber is protected from fire by the United States throughout the life of the contract. The money deposited to secure cutting in advance of the execution of the contract may be credited towards the amount to accompany the bid.

Stum page Rates. The minimum stumpage rates applicable in each proposed sale are determined by a careful study of the conditions in the particular case. Stumpage rates are the actual market value of the timber. They are based upon the quality of the timber and the character of its commercial products; the estimated cost of logging, transportation, and manufacture; the investment required on the part of the operator; the selling value of the product; and a fair profit to the purchaser. The estimated profit depends upon the size and the permanency of the operation and the degree of risk involved. The cost of brush disposal, protection of young growth, logging only marked timber and other requirements of the Forest Service is fully considered in appraising stumpage rates.

Timber is ordinarily appraised at the rates indicated for the most valuable products to which it is suited and for which an established market exists. Merchantable dead timber is appraised at the same 
rate as green timber of the same species unless it is clearly shown that the products manufactured from it command a lower market price or that logging costs are higher.

Cutting Period. Ordinarily the cutting period allowed in each sale is only sufficient to permit the removal of the timber at a reasonable rate, approximately equivalent to the working capacity of the plant. Sales of accessible timber usually do not exceed 5 years in length. However, in the case of inaccessible tracts requiring a large investment for transportation facilities an exception is made and periods of from 15 to 20 years may be granted.

Readjustment of Stumpage Rates. In all sales exceeding 5 years in length provision is made to have the stumpage rates readjusted by the Forester at the end of three or five year intervals to meet changing market and manufacturing conditions.

Refunds. Deposits to cover or secure advance cutting or to accompany bids apply on the first payment if a sale is awarded to the depositor; otherwise they will be refunded. Refunds are also made to the purchaser if the last payment is in excess of the value of the timber that is cut. 


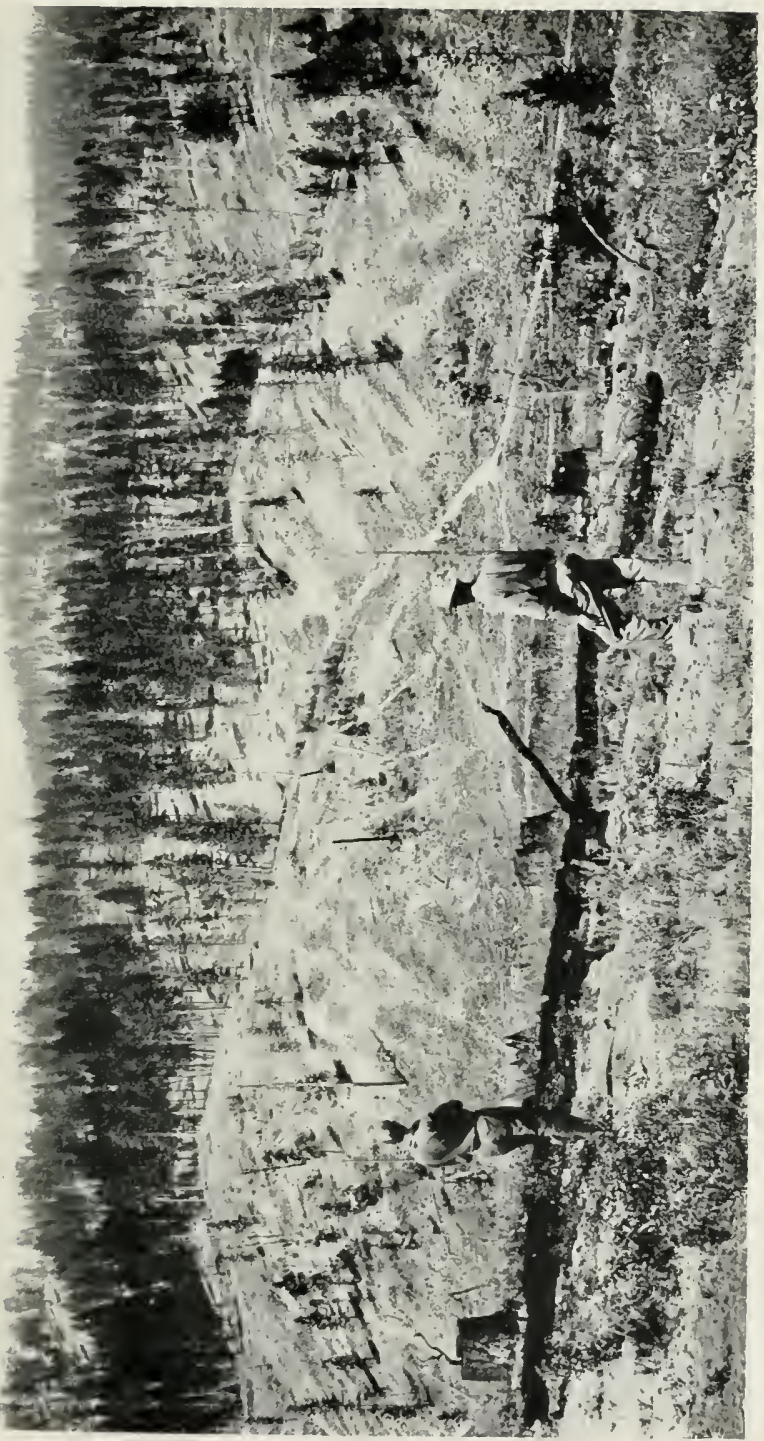

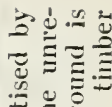

过

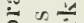

츠른

$\approx \Xi \bar{\Xi}$

20 $\Xi \cong \Xi$

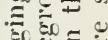

$\underbrace{}_{i=0} \underbrace{}_{0} \equiv$

…

$\bar{\Xi}$

艺艺

$\Xi \Xi$

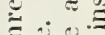

$\Xi$.

$=\approx+$

$\overline{0}=$

$+ \pm \overline{0}$

$=$

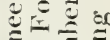

ఏ引引

$2=+5$

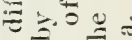

$\cong=\frac{1}{ \pm}$

- क्ष है

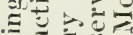

$=0$

$\equiv 三 \overline{2}$

$\approx \div \div \div$

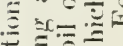

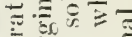

药

三五五

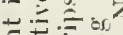

플 $\Xi$

$=\div$ 政

$\bar{y}=30$

急气

$\approx \overline{0}$

플

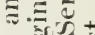

$x=3 x$ w

过是

$\Xi \Xi$

:0

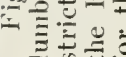



THE DISPOSAL OF TIMBER TO HOMESTEAD SETTLERS AND UNDER FREE USE

Besides selling the timber and other forest products outright, as has just been described, some timber is sold to settlers at cost and much timber is given away to the local people under the free use policy.

Sales to Homestead Settlers and Farmers. Sales to homestead settlers and farmers are made without advertisement in any amount desired, at the price fixed annually for each National Forest region of similar conditions by the Secretary, as equivalent to the actual cost of making and administering such sales. Only material to be used by the purchaser for domestic purposes exclusively on homesteads or farms is sold in this way. Such uses include the construction or repair of farm buildings, fences, and other improvements and fuel. Such sales are restricted to mature dead and down timber which may be cut without injury to the forest.

Free Use. Free use of timber is granted primarily to aid in the protection and silvicultural improvement of the Forests. Hence the material taken is, except in unusual cases, restricted to dead, 
insect infested and diseased timber, and thinnings. Green material may be taken in exceptional cases where its refusal would clearly cause unwarranted hardship. The use of such material is granted freely: (1) To bona fide settlers, miners, residents, prospectors, for fire wood, fencing, building, mining, prospecting, and other domestic purposes; and to any one in case its romoval is necessary for the welfare of the Forest; (2) for the construction of telephone lines when necessary for the protection of forests from fire; (3) to certain branches of the Federal Government. Free use is not granted for commercial purposes or of use in any business, including sawmills, hotels, stores, companies or corporations. Such persons are required to purchase their timber.

The aggregate amount of free use material granted annually to any user must not exceed $\$ 20$ in value, except in cases of unusual need or of dead or insect infested timber, the removal of which would be a benefit to the forest, or in the case of any timber which should be removed and whose sale under contract cannot be effected. In these cases the amount may be extended to $\$ 100$. Supervisors have authority to grant free use permits up to 


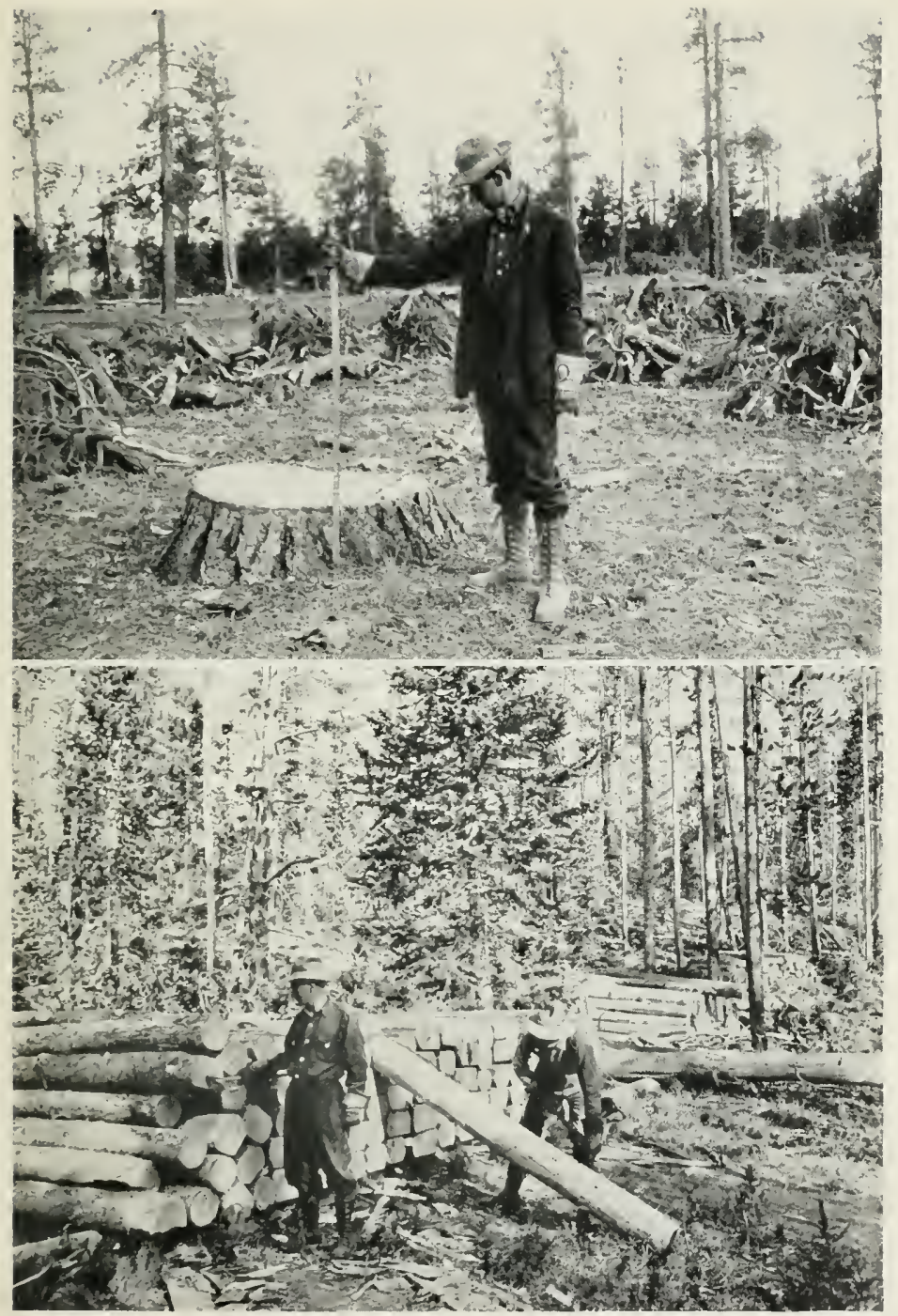

Figure 69. View showing the Forest Service method of piling the brush and débris after logging, and also how stump heights are kept down to prevent waste. New Mexico.

Figure $r 0$. A tie-eutting operation on a National Forest. These piles of railroad ties are being inspeeted, stamped, and counted by Forest rangers. From this point the ties are "skidded" to the banks of a stream to be floated to the shipping point. Near Evanston, Wy yoming. 



\section{NATIONAL FOREST RESOURCES 197}

$\$ 100$, District Forester's up to $\$ 500$, and larger amounts must have the approval of the Forester.

Free use material is appraised in the same manner and in accordance with the same principles as timber purchased under sale agreements. The valuation of such material is at the same rate as that prevailing for similar grades of stumpage in current sales in the same locality.

The magnitude of the free use business may be appreciated from the fact that during the fiscal year 1917 there were 41,427 individuals or companies who received timber under this policy. The total amount thus given away was $113,073,000$ board feet valued at over $\$ 150,000$.

Permits for this use are required for green material, but dead timber may be taken without a permit. Supervisors designate as free-use areas certain portions or all of any National Forest and settlers, miners, residents, and prospectors may cut and remove from such areas free of charge under Forest Service regulations any timber needed for their own use for firewood, fencing, buildings, mining, prospecting, or other domestic purposes.

Material cut under free-use regulations must not be removed from the cutting area until scaled or 
measured by a Forest officer. In some cases this requirement is waived when by it the needs of the users are met with greater dispatch and the cost of administration is thereby reduced. The free-use applicant is required to utilize the trees cut in accordance with local Forest Service practice and he is required to avoid unnecessary damage to young growth and standing timber.

\section{TIMBER SETTLEMENT AND ADMINISTRATIVE USE}

When timber on National Forest land is cut, damaged, killed, or destroyed in connection with the enjoyment of a right-of-way or other special use, it is not necessary to advertise it for sale, but payment therefor is required at not less than the minimum rate established by the Secretary of Agriculture. Timber removed in this way is usually scaled, measured, or counted and the procedure is identical with that of a timber sale. But where timber is destroyed or where it is not worked up in measurable form or where the cutting is done in such a way that scaling is impracticable, settlement is required on the basis of an estimate.

In 1912 a new branch of the Southern Pacific Railroad was built across a portion of the Lassen 


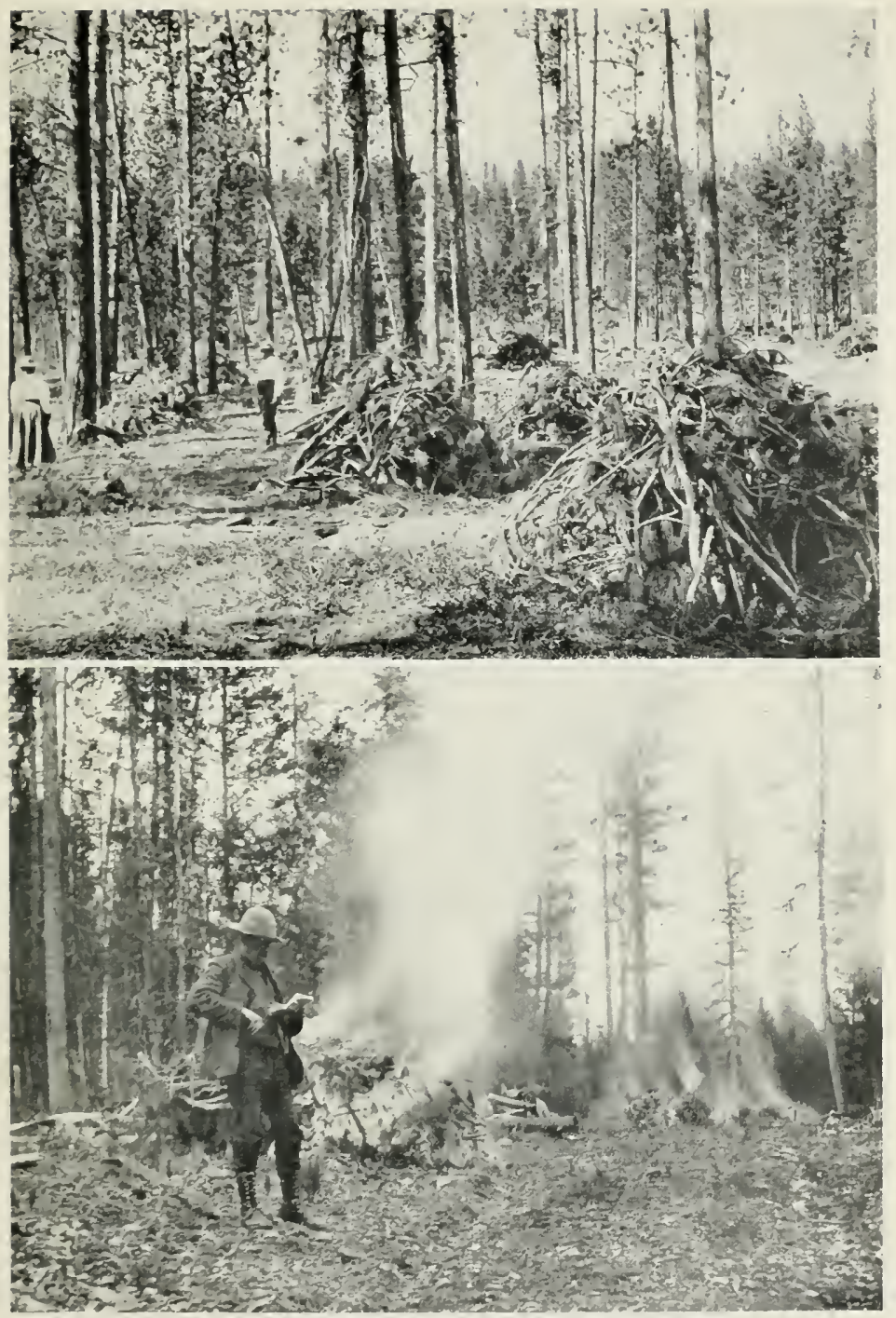

Figure 11 . Brush piles on a cut-over area before burning. Forest Serrice methods ain to ("lean up the forest after logging so that forest fires have less inflammable material to feed on. Bitterroot National Forest. INontana.

Figure iz. It a time of the year when there is last danger from fire the hrush piles are burned. Missoula National Forest, Montana. 
National Forest in California. The company was going to use some of the timber, but most of it was to be destroyed or disposed of in the easiest manner. Scaling was impossible, so the company paid for the timber-about $\$ 10,000$ - on the basis of a careful estimate made by the writer, then Forest Examiner.

The charge for all such timber is made on the basis of the current stumpage rates for timber of like quality and accessibility included in sales for all classes of material which have to be cut or destroyed and which are commonly salable on the Forest.

Timber is often used by the Forest Service itself in the administration of the National Forests. The Forester, District Foresters, and the Supervisors are authorized to sell or dispose of under free use or otherwise, within the amount each one is authorized to sell, any timber upon the National Forests when such removal is actually necessary to protect the Forest from ravages or destruction, or when the use or removal of the timber is necessary in the construction of roads, trails, cabins, and other improvements on the National Forests or in experiments conducted by the Forest Service. 
THE RENTAL OF NATIONAL FOREST RANGE LANDS

The forage crop on the National Forests is for the use of the sheep and cattle of the western stockmen and it is procured by means of grazing permits which are issued and charged for upon a per capita basis. The primary objects of the administration of government grazing lands are: the protection and conservative use of all National Forest land adapted to grazing; the permanent good of the live stock industry through the proper care and use of grazing lands; and the protection of the settler and home builder against unfair competition in the use of the range.

Importance of the Live Stock Industry. The grazing business, more than any other feature of National Forest management, is immensely practical, because it is immediately concerned with human interests. This industry furnishes not only meat, but leather, wool, and many by-products.

That the National Forests play a big part in the maintenance of this industry there can be little doubt, for it has been estimated recently that $\mathbf{3 0}$ per cent. of the sheep and 20 per cent. of the cattle of the far Western States are grazed in the $\mathrm{Na}$ - 


\section{NATIONAL FOREST RESOURCES 201}

tional Forests. The Forests contain by far the largest part of the summer range lands in the far Western States and hence are of paramount importance. The winter grazing lands in the West are so much greater in area than the summer lands, that for this reason also National Forest range lands are in great demand.

Permits Issued in 1917. During the fiscal year 1917 more than 31,000 permits to graze cattle, hogs, or horses, and over 5,500 permits to graze sheep or goats were issued. These permits provided for $2,054,384$ cattle, 7,586,034 sheep, about 100,000 horses, about 50,000 goats, and about 3,000 hogs. The total receipts for 1917 were over $\$ 1,500,000$. The gross receipts to the owners of the stock probably exceeded $\$ 50,000,000$ and the capital invested in the stock no doubt amounted to over $\$ 200,000,000$.

An idea of the growth of the grazing business may be gotten from the Forest Service statistics for the fiscal years 1908 and 191\%. The increase in the number of permits and the volume of the business is due primarily to a better administration and better regulation of grazing interests and more specifically to the increase in the carrying capacity 
of government lands by wise and restricted use. Between these two fiscal years there was no appreciable increase in the total area of the Forests which would account for the increased business. In 1908 there were issued 19,845 permits for $1,382,-$ 221 cattle, horses and hogs; in 1917 there were issued 31,136 permits for 2,054,384 animals. In 1908 there were issued 4,282 permits for $7,087,111$ sheep and goats; in 19175,502 permits were issued for 7,586,034 sheep and goats. The number of cattle and horses grazed has increased therefore by 50 per cent. and the number of sheep and goats by 7 per cent. The total receipts have increased from $\$ 962,829.40$ in 1908 to $\$ 1,549,794.76$ in 1917.

Kinds of Range, Grazing Seasons, and Methods of Handling Stock. For the proper understanding of the grazing business on the National Forests it is necessary to know something about the different kinds of range, the length of grazing seasons, and the methods of handling different classes of stock. Sheep and goat range differs materially from cattle and horse range and the proper distribution of stock over a National Forest cannot be effected unless this difference is recognized. Sheep and goat range usually consists of low shrubs or 


\section{NATIONAL FOREST RESOURCES 203}

brush and is known collectively as "browse"; cattle and horses subsist mainly upon grass, flowering plants and herbs. Sheep feel more at home on high mountain slopes, while cattle and horses range usually on the lower slopes and in the valleys, and especially in the broad meadows, around lakes and along streams. Sheep are more apt to find feed in the forests, that is under the trees; cattle prefer the open; they usually avoid the forest, preferring to keep out on the open meadows and grassy slopes.

Naturally some ranges have feed at some seasons of the year and other ranges at other seasons. Some of the National Forests in California extend from an elevation of a few hundred feet in the foothills of the great valleys to an elevation of more than 10,000 feet at the crest of the Sierra Nevada Mountains. The lower foothills afford excellent feed soon after the beginning of the fall rains in November and, due to the very mild winter which this region enjoys, there is excellent feed in February and March. This is known as winter range. The medium high slopes of the mountains have a later growing season and the sheep and cattle reach there about June and stay until August or September. Still higher up the forage matures 
later and the grazing season extends from August until Norember. At these elevations the snowbanks usually lie until July and the growing season is very short, for the new snow usually buries the vegetation about the first of November. Thus stockmen have what they call "winter range," "summer range," and "fall range," depending upon what seasons of the year the forage crop can be utilized. The National Forests on the whole contain very little winter range, hence stockmen must move their stock in the fall to private lands at lower elevations either where the climate is considerably warmer or where there is very little snowfall. A large part of the western winter grazing lands are in regions of light snowfall, such as at the lower elevations in Utah, Nevada, Wyoming, and Colorado. Here the stock feeds on dry grass. Stockmen who cannot get winter range lands must feed their stock at ranches.

The characteristic habits of sheep and cattle require that they be handled differently on the range. Sheep are herded in bands while cattle are handled in scattered groups. The new and approved method of handling sheep called the "burro system" calls for a burro with the sheep to pack the 
herder's blankets and provisions. The herder camps where night overtakes him. The herder and his band keep moving over the allotted range from one camp to another until he has covered the whole range. After leaving his last camp he is ready to begin all over again, since the feed near the camp where he began has had two to three weeks' time to grow a new crop. Cattle usually run loose singly or in groups on their allotted range. Usually a range rider is camped on the range to keep the cattle from straying to other ranges. He salts the cattle to keep them on their own range, takes care of cattle that have gotten sick, and takes care of the stock in other ways.

Grazing Districts and Grazing Units. The Secretary of Agriculture not only has the authority to regulate grazing and prescribe the schedule of grazing fees to be charged but he also regulates the number and class of stock which are allowed to graze on each National Forest annually.

The ranges within the National Forests are used by the kind of stock for which they are best adapted except when this would not be consistent with the welfare of local residents or the proper protection of the Forests. For convenience in administration 
Forests are divided into grazing districts. A typical Forest is divided into from 4 to 6 districts which may be natural grazing units, natural administrative units (coinciding with the Ranger districts), or parts of the Forest used by different classes of stock or parts of the Forest having different lengths of grazing seasons. Each grazing district is also subdivided into smaller divisions, units, or allotments. These are usually natural divisions defined by topographic boundaries, such as ridges, mountains, streams, etc., or more or less artificial divisions determined by the class of stock which uses them. For example, cattle and horses ordinarily graze in the valleys along the streams, while sheep and goats graze the crests of ridges and the slopes of mountains and will cross none but shallow streams. Each range division or unit is usually given a wellknown local name, such as "Duck Lake Unit" or "Clover Valley Unit." One or more stockmen may be allotted to such a unit, depending upon the size of the unit and the number of animals it can feed. If only one stockman.uses it, it becomes an individual allotment. Usually a sheep owner with several large bands of sheep is allotted one large unit adapted to sheep grazing, while a large unit 


\section{NATIONAL FOREST RESOURCES 207}

adapted to cattle and horses may be allotted to one large cattle owner or to two or more smaller owners. The manner in which sheep and goats are handled makes individual allotments both practicable and desirable.

The boundaries of range allotments are usually well defined. In the case of sheep they are marked with cloth posters. In most Forests range allotments are fairly well settled. Each stockman gets with his permit each spring a small map showing his own range and the surrounding ranges.

Who Are Entitled to Grazing Privileges. The Secretary of Agriculture has the authority to permit, regulate, or prohibit grazing on the National Forests. Under his direction the Forest Service allows the use of the forage crop as fully as the proper care and protection of the National Forests and the water supply permit. The grazing use of the National Forest lands is therefore only a personal and non-transferable privilege. This privilege is a temporary one, allowable under the law only when it does not interfere with the purposes for which the National Forests were created. It is non-transferable because it is based upon the possession of certain qualifications peculiar to the per- 
mittee. To understand these qualifications it is necessary to briefly look into the history of the grazing of live stock on the western grazing lands.

By long use of the public lands of the United States for grazing purposes, long before the $\mathrm{Na}$ tional Forests were created, stock owners have been allowed to graze their stock upon such lands under certain conditions of occupancy, residence, and ownership of improved lands and water rights. This use, continuing through a long period of years, has, in the absence of congressional legislation, been commonly accepted in many communities, even receiving the recognition of certain of the courts. It was allowed under "unwritten law," as it were, only by the passive consent of the United States, but by force of the presidential proclamation creating National Forests, such passive consent ceased, being superseded by definite regulations by the Secretary of Agriculture prescribed under the authority of Congress. Therefore grazing stock on the Forests, as it was done before the Forests were created, is trespass against the United States. Due to the fact that local stockmen have used certain public ranges year after year by the passive consent of the United States, these stock- 

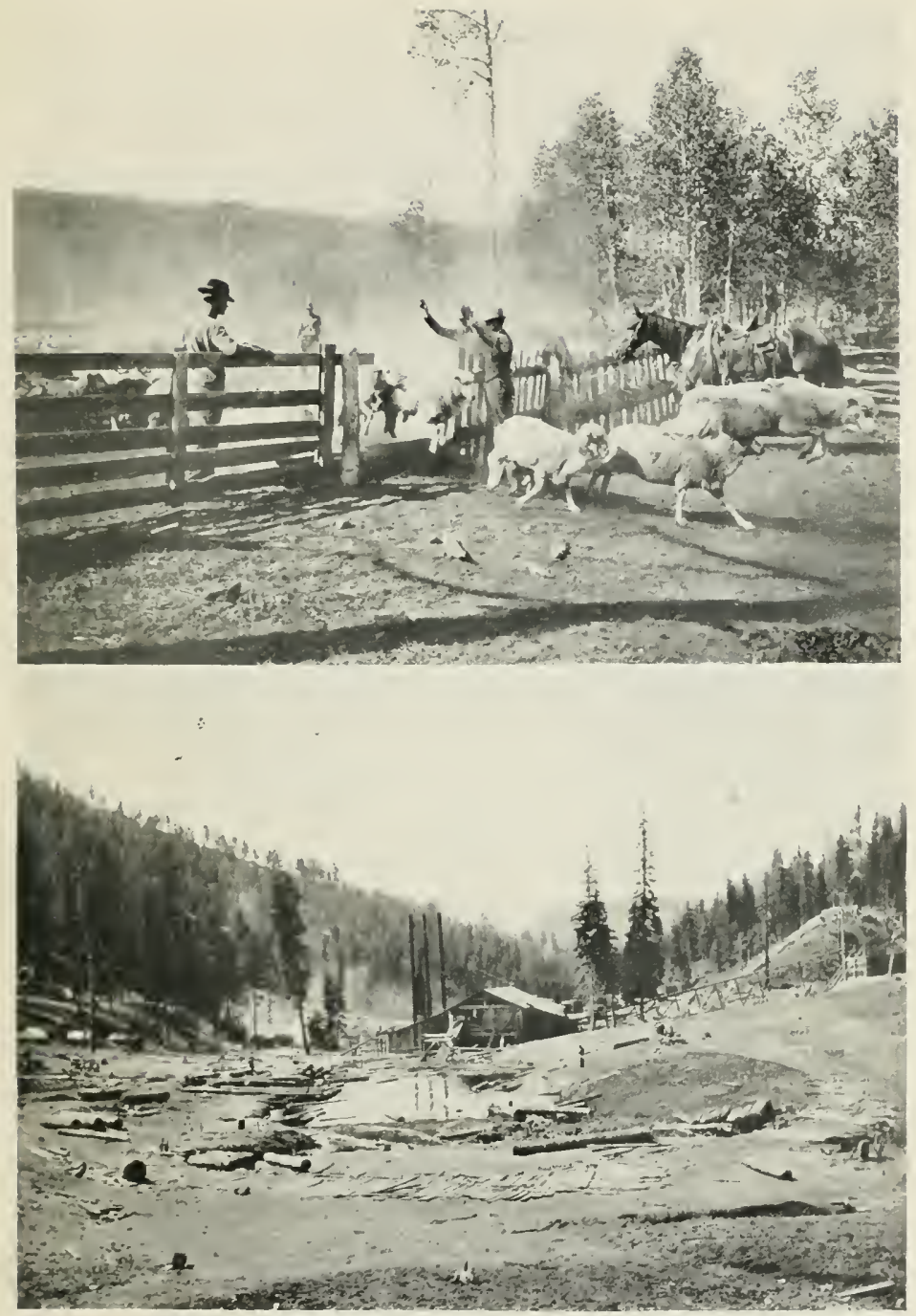

Figure 73. Counting sheep as they leave the corral. Sheep and eattle are pastured on National Forests at so many cents per head, hence they must be connted before they enter in the spring. Wasatch Cational Forest, ['tah.

Figure it. Iogging National Forest timber. Santa Fe National Forest, New Mexico. 

men are recognized in these localities as having preference rights or equities in the use of range lands. These equities form the basis upon which grazing privileges are allowed.

Grazing permits are issued only to persons entitled to share in the use of the range within the $\mathrm{Na}$ tional Forests by reason of their fulfilling certain conditions or requirements. Prior use and occupancy of National Forest lands for grazing purposes is the first and foremost requirement. Local residence and ownership of improved ranch property within or near the Forest and dependence upon government range are also conditions that may entitle a stockman to grazing privileges. The Forest Service also recognizes those stockmen who have acquired by purchase or inheritance stock grazed upon National Forest lands under permit and improved ranch property used in connection with the stock, provided circumstances warrant the renewal of the permit issued to the former owner. The regular use of a range during its open season for several successive years before the creation of the National Forest and under grazing permit thereafter is what is meant by "prior use" or "regular occupancy." 'The longer the period or use the 
greater the preference right. No one can acquire this right to the use of National Forest range, nor can it be bought or sold, but stockmen may acquire a preference in the allotment of grazing privileges. This preference right does not entitle him to continued use of a certain part of a Forest, but only to preference over other applicants less entitled to consideration in the use of the ranges open to the class of stock which he wishes to graze. Certain stockmen may be given preference in ranges secured by prior use and occupancy supplemented by heavy investments in improved property and water rights.

Citizens of the United States are given preference in the use of the National Forests, but persons who are not citizens may be allowed grazing permits provided they are bona fide residents and owners of improved ranch property either within or adjacent to a National Forest. Regular occupants of the range who own and reside upon improved ranch property in or near National Forests are given first consideration, but will be limited to a number which will not exclude regular occupants who reside or whose stock are wintered at a greater distance from the National Forests. With this pro- 
vision applicants for grazing permits are given preference in the following order:

Class A. Persons owning and residing upon improved ranch property within or near a National Forest who are dependent upon National Forests for range and who do not own more than a limited number of stock (known as the protective limit).

Class B. Regular users of National Forests range who do not own improved ranch property within or near a $\mathrm{Na}$ tional Forest, and persons owning such ranch property but who own numbers of stock in excess of the established limit.

Class C. Persons who are not regular users of the National Forest range and who do not own improved ranch property within or near a National Forest. Such persons are not granted permits upon Forests which are fully occupied by classes A and B. Classes B and C are not allowed to increase the number of stock grazed under permit except by the purchase of other permitted stock.

From this classification it is very evident that the small local stockmen who own approximately from 30 to 300 head of cattle and from 500 to 2,000 head of sheep and who own and reside upon the ranches near the Forests are given the preference in the allotment of grazing privileges.

Grazing Permits. Various kinds of grazing permits are required each year on the National Forests. These are known as ordinary grazing per- 
mits, on-and-off permits, private land permits, and crossing permits.

All persons must secure permits before grazing any stock on a National Forest except for the few head in actual use by prospectors, campers, ranchers, stockmen, and travelers who use saddle, pack and work animals, and milch cows in connection with permitted operations on the National Forests. Under these conditions $\mathbf{1 0}$ head are allowed to graze without permit.

Persons owning stock which regularly graze on ranges partially included within a National Forest, or upon range which includes private land may be granted permits for such portions of their stock as the circumstances appear to justify. This regulation provides for cases where only a part of a natural range unit is National Forest land, and where the economical use of the entire unit can be secured only by the utilization of the Forest land in connection with the other land. The regulation contemplates a movement of the stock governed by natural conditions, between the Forest range and the adjoining outside range, or between Forest land and intermingled private land. This is called an on-and-off permit. 
Permits on account of private lands are issued to persons who own, or who have leased from the owners, unfenced lands within any National Forest which are so situated and of such a character that they may be used by other permitted stock to an extent rendering the exchange advantageous to the Government. The permits allow the permittees to graze upon National Forest land, free of charge, the number of stock which the private lands will support, by waiving the right to the exclusive use of the private land and allowing it to remain open to other stock grazed on National Forest land under permit.

The regular grazing permit carries with it the privilege of driving the permitted stock over $\mathrm{Na}$ tional Forest lands to and from the allotted ranges at the beginning and end of the grazing season and from the range to the most accessible shearing, dipping, and shipping points during the term of the permit. But crossing permits are necessary for crossing stock over National Forest lands to points beyond the National Forest, for crossing stock to private lands within a National Forest, or for crossing stock to reach dipping vats or railroad shipping points. Rangers sometimes are detailed to accom- 


\section{OUR NATIONAL FORESTS}

pany the stock and see that there is no delay or trespassing. No charge is made for crossing permits, but it is absolutely necessary that persons crossing stock comply with the regulations governing the National Forests and with the quarantine regulations prescribed by the Secretary of Agriculture and the state authorities.

Grazing Fees. The full grazing fee is charged on all animals under 6 months of age which are not the natural increase of stock upon which the fees are paid. Animals under 6 months which are the natural increase of permitted stock are not charged for. A reasonable fee is charged for grazing all kinds of live stock on National Forests. The rates are based upon the yearlong rate for cattle, which is from 60 cents to $\$ 1.50$ per head, depending upon conditions on the Forest. The yearlong rates for horses are 25 per cent. more and the yearlong rate for swine 25 per cent. less than the rate for cattle. The rate for sheep is 25 per cent. of the yearlong rate for cattle. The rates for all kinds of stock for periods shorter than yearlong are computed in proportion to the length of the season during which the stock use National Forest lands. All grazing fees are payable in advance. 
When notice of the grazing allowance, periods, and rates for the year has been received by the Supervisor he gives public notice of a date on or before which all applications for grazing must be presented to him. These public notices are posted in conspicuous places, usually in the post offices. Applications for grazing permits are submitted on blank forms furnished by the Supervisor. As soon as an applicant for a grazing permit is notified by the Supervisor that his application has been approved, he must remit the amount due for grazing fees to the District Fiscal Agent and upon receipt of notice by the Supervisor that payment has been made a permit is issued allowing the stock to enter the Forest and remain during the period specified. All grazing fees are payable in advance and the stock is not allowed to enter the National Forest unless payment has been made.

Stock Associations. The thirty or more grazing regulations effective on the National Forests are for the primary purpose of making the National Forest range lands as useful as possible to the people consistent with their protection and perpetuation. It is clearly impossible to meet the wishes and needs of each individual user, but it is often 
entirely possible to meet the wishes of the majority of users if made known through an organization. The organization of stock associations is encouraged by the Forest Service and the opinions and wishes of their advisory boards are recognized when they represent general rather than individual or personal interests. It is often possible through these organizations to construct range improvements such as corrals, drift fences, roads, trails, and sources of water supply for the common good of the members of the organization and paid for by them.

Protective and Maximum Limits. In order to secure an equitable distribution of grazing privileges, the District Forester establishes protective limits covering the number of stock for which the permits of Class $A$ owners will be exempt from reduction in the renewal of their permits. Permits for numbers in excess of the protective limits will be subject to necessary reductions and will not be subject to increase in number except through purchase of stock or ranches of other permittees.

Protective limits are established to protect permittees from reduction in the number of stock which they are allowed to graze under permit below 

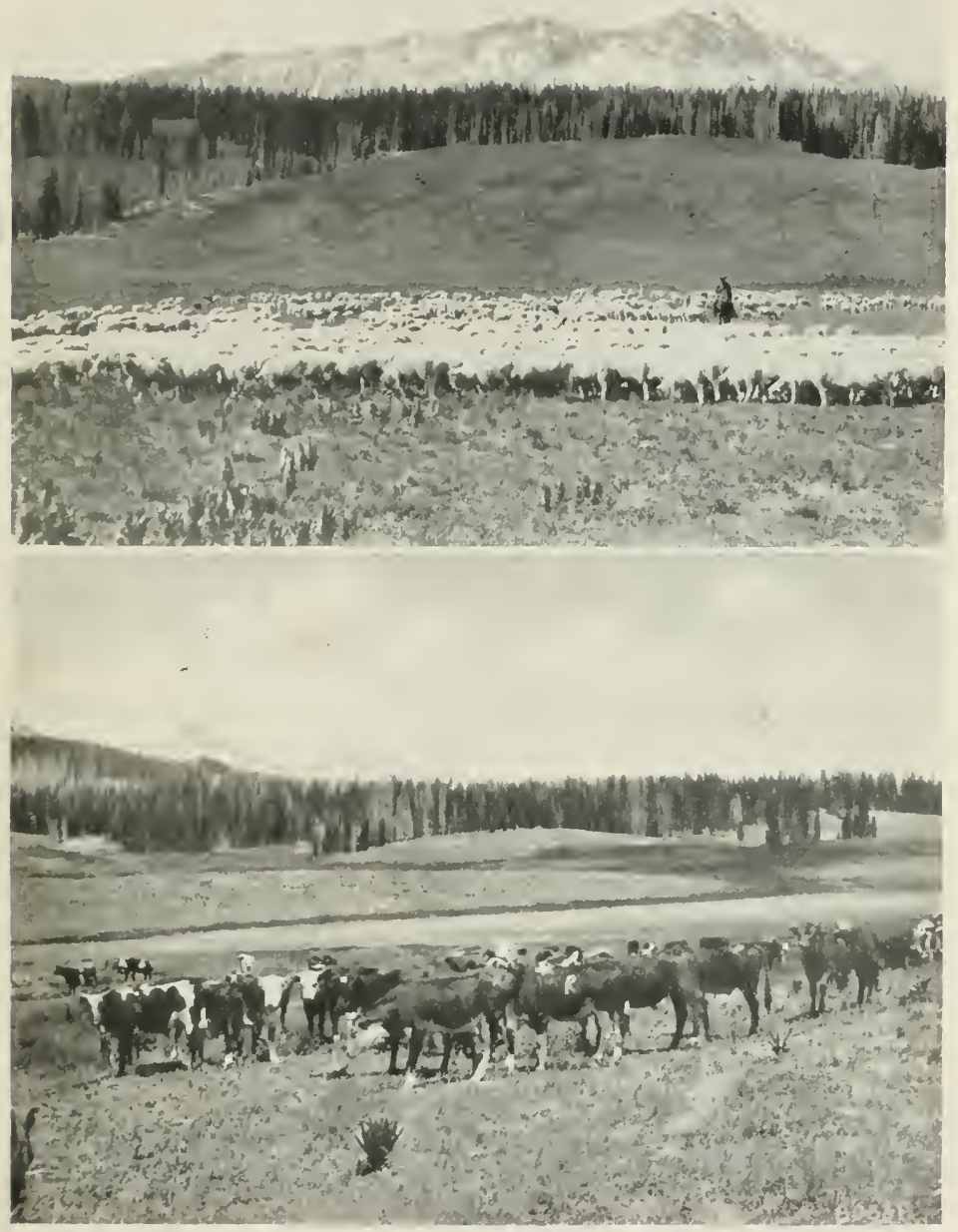

ligure is. Sheep grazing on the Montemuma Vational Forest at the foot of Mt. Wilson, Colorirlo. Over $;, 500,000$ shere $)$ and goats grazed on the National Forests during the fiscal year $191 \%$.

Figure ifo. Grazing cattle on a National Forest in Colorarlo. Permits were issued during 1917 to graze orer 2,000,000 cattle, horses, and swine on the National Forests. 

a point where the business becomes too small to be handled at a profit or to contribute its proper share toward the maintenance of a home. The average number of stock which a settler must graze in order to utilize the products of his farm and derive a reasonable profit is determined upon each Forest or, if necessary, upon each grazing district thereof, and serves as the basis for the protective limit. Protective limits have been established for various Forests running from 25 to 300 head of cattle and from 500 to 2,000 head of sheep and goats.

Increases above the protective limit are allowed only to purchasers of stock and ranches of permit holders and any such increase must not exceed the maximum limit. Class A permittees owning a less number of stock than the protective limit are allowed to increase their number gradually. Whenever it is found necessary to reduce the number of stock allowed in any National Forest, Class C stock is excluded before the other classes are reduced. The reduction on a sliding scale is then applied to Class B owners. Class A owners are exempt from reduction. When new stock owners are allowed the use of National Forest range upon a Forest already fully stocked, reductions in the number of 
permitted stock of Class B and C owners is made in order to make room for the new man. Thus it is seen that the matter of protective limits is actually a protection to the small stock owner; he is protected from the monopoly of the range by big corporations.

When necessary to prevent monopoly of the range by large stock owners, the District Forester establishes maximum limits in the number of stock for which a permit may be issued to any one person, firm or corporation.

Prohibition of Grazing. It often becomes necessary to prohibit all grazing on an area within a National Forest or at least to materially reduce the amount of stock which is allowed to graze on a given area. Sheep may be excluded from a timber-sale area for a certain number of years after cutting or until the reproduction has become well established. Where planting operations are being carried on it is usually necessary to exclude all classes of stock. If investigations show that grazing is responsible for the lack of reproduction over a considerable area, the area or a portion of it may be withdrawn from range use until young growth has become established again. The watersheds of streams sup- 
plying water for irrigation, municipal or domestic purposes may be closed to grazing of any or all kinds of domestic stock when necessary to prevent erosion and floods or diminution in water supply. Camping grounds required for the accommodation of the public may be closed to the grazing of permitted stock. Limited areas which are the natural breeding or feeding grounds of game animals or birds may be closed to grazing. Areas within National Forests infested seriously by poisonous plants may be closed to grazing.

Protection of Grazing Interests. The protection of National Forest grazing interests is secured by the prevention of overgrazing, by the prevention of damage to roads, trails, or water sources, by the proper bedding of sheep and goats, by the proper disposition of carcasses, by salting the stock and by the proper observation of the national and state live stock and quarantine laws.

When an owner, who has a permit, is ready to drive in his stock upon the National Forest he must notify the nearest Forest officer concerning the number to be driven in. If called upon to do so he must provide for having his stock counted before entering a National Forest. Each permittee must 
repair all damage to roads or trails caused by the presence of his stock. Sheep and goats are not allowed to be bedded more than three nights in succession in the same place (except during the lambing season) and must not be bedded within 300 yards of any running or living spring. The carcasses of all animals which die on the National Forests from contagious or infectious diseases must be burned and are not permitted to lie in the close vicinity of water. In order to facilitate the handling of stock and prevent their straying off their range, they must be salted at regular intervals and at regular places.

In order to facilitate the moving of stock by stockmen from their home ranches to their grazing allotments and to minimize the damage of grazing animals to the Forests, stock driveways are established over regular routes of travel.

\section{SPECIAL USES}

All uses of National Forest lands and resources permitted by the Secretary of Agriculture, except those specifically provided for in the regulations covering water power, timber sales, timber settlement, the free use of timber, and grazing, are desig- 
nated "special uses." Among these are the use or occupancy of lands for residences, farms, apiaries, dairies, schools, churches, stores, mills, factories, hotels, sanitariums, summer resorts, telephone and telegraph lines, roads and railways; the occupancy of lands for dams, reservoirs and conduits not used for power purposes; and the use of stone, sand, and gravel. No charge is made for a large number of these permits, some of which are the following: (1) agricultural use by applicants having preference rights under the Act of June 11, 1906; (2) schools, churches, and cemeteries; (3) cabins for the use of miners, prospectors, trappers, and stockmen in connection with grazing permits; (4) saw mills sawing principally National Forest timber; (5) conduits, and reservoirs for irrigation or mining or for municipal water supply; (6) roads and trails (which must be free public highways); (7) telephone lines and telegraph lines with free use of poles and connections for the Forest Service.

The occupancy and use of National Forest land or resources under a special use permit (except those given free of charge) are conditioned upon the payment of a charge and are based upon certain rates. Agricultural use of land is given to permit- 
tees at a charge of from 25 cents to $\$ 1.00$ an acre. Not over 160 acres are allowed to any one permittee. Cabins cost from $\$ 3.00$ to $\$ 5.00$; hay cutting from 20 to 50 cents an acre; hotels and roadhouses from $\$ 10.00$ to $\$ 50.00$; pastures from 4 to 25 cents per acre; residences covering from one to three acres cost from $\$ 5.00$ to $\$ 25.00$; resorts from $\$ 10.00$ to $\$ 50.00$; stores from $\$ 5.00$ to $\$ 50.00$ for two acres or less; and other uses in proportion.

Perhaps the use that is purchased most of all on the National Forests is that for residences and summer homes. On many of the Forests they are already in great demand. A large proportion of the population of the far Western States seek the cool and invigorating air of the mountains in the early summer because the heat of the valleys, especially in California, is almost unbearable.

There are many desirable pieces of land on the National Forests that are being reserved by the Forest Service especially for this purpose for the people of the neighboring towns. For example, on the Angeles National Forest in California the Supervisor had about 250 suitable sites surveyed in one picturesque canyon and in six months 226 of them were under special use permits as summer homes. 
A large reservoir-Huntington Lake-was constructed on the Sierra National Forest in California as the result of a dam constructed by a hydroelectric power company. Immediately there was a keen demand among the residents of San Joaquin Valley for summer homes on the shores of the lake. In a few years it is expected there will be a permanent summer colony of from 2,000 to 3,000 people. The Forest Service has already authorized an expenditure of $\$ 1,500$ in order to furnish an adequate supply of domestic water for the colony.

\section{CLAIMS AND SETTLEMENT}

Claims can be initiated upon National Forest lands under (1) the Act of June 11, 1906, (2) under the mining laws, and (3) under the coal land laws. In connection with these claims it is the duty of the Forest Service to examine them, but the determination of questions involving title is within the jurisdiction of the Secretary of the Interior.

It is the purpose of the Forest Service to protect the lands of the United States within the National Forests from acquisition by those who do not seek them for purposes recognized by law. When it is apparent that an entry or a claim is not initiated 
in good faith and in compliance with the spirit of the law under which it was asserted, but is believed from the facts to be a subterfuge to acquire title to timber land, or to control range privileges, water, a waterpower site, or rights of way; or if it otherwise interferes with the interests of the National Forests in any way, the Forest Service recommends a contest, even if the technical requirements of the law appear to have been fulfilled. It is bad faith, for instance, to hold a mining or agricultural claim primarily for the timber thereon or to acquire a site valuable for water power development.

The National Forest Homestead Act. At the present time there is very little, if any, fraud connected with the Forest Homestead Act because the land is classified before it is opened to entry. The greater part of the work dealing with fraudulent claims is a relic of the old régime. Before the Forests were established many Homestead and Timber and Stone entries were made for the purpose of securing valuable timber. A large number of persons resorted to settlement in order to secure the preference right. It was the common custom in those days for land cruisers to locate men on heavily timbered land either before or immediately after 
survey and before the filing of the plats and the opening of the land to entry. A cabin would be built upon the land and some unsubstantial improvements made. When the National Forests were created they contained great numbers of these squatters' cabins. Many were abandoned but others attempted to secure title. Under the old Timber'and Stone Act timber could be secured for $\$ 2.50$ per acre, but the National Forests are not subject to entry under this act. So as a last resort the squatters tried to prove up on the land under the Homestead law. When the Forests were created the Service found a great many of these fraudulent claims on their books, many of which were being brought up annually for patent. Between December, 1908, and June 30, 1913, a total of 498 entries for National Forest land were canceled in a single administrative district. These entries represented fraudulent efforts to secure title to 85,906 acres of National Forest land for speculative purposes, involving nearly a billion feet of merchantable timber. During the fiscal year 1913 alone 300,000,000 board feet of merchantable timber in one district was retained in public ownership primarily because the Forest officers brought out the facts. The lands 
in all cases were covered with heavy stands of timber, very small portions of the land had been cleared, the claimant's residence on the land was not in compliance with the law, seldom was any crop raised on the land, and the claimant in other ways did not carry out the intent of the law.

The Act of June 11, 1906, known as the National Forest Homestead Act, provides for the acquisition by qualified entrymen of agricultural lands within National Forests. The Act is in effect an extension of the general provisions of the Homestead laws to the agricultural lands within the National Forests, with the essential difference that the land must be classified by the Secretary of Agriculture as chiefly valuable for agriculture.

This Act authorizes the Secretary of Agriculture in his discretion to examine and ascertain, upon application or otherwise, the location and extent of lands both surveyed and unsurveyed in the National Forests, chiefly valuable for agriculture, which may be occupied for agricultural purposes without injury to the National Forests or public interests. He is authorized to list and describe such lands by metes and bounds or otherwise and to file such lists and descriptions with the Secretary of the 
Interior for opening to entry in accordance with the provisions of the Act. Agricultural lands listed by the Secretary of Agriculture are opened by the Secretary of the Interior to homestead entry in tracts not exceeding 160 acres at the expiration of 60 days from the filing of the lists in the local Land Office. Notice of the filing of the list is posted in the local Land Office and is published for a period of not less than four weeks in a local newspaper. The Act provides that the person upon whose application the land is examined and listed, if a qualified entryman, shall have the preference right of entry. To exercise this preference right, application to enter must be filed in the local Land Office within 60 days after the filing of the list in that office. The entryman ean perfect his title to the land within a certain period of years by fulfilling certain conditions of residence and cultivation.

By the Act of June 6, 1912, known as the "Three Year Homestead Act," the period of residence necessary to be shown in order to entitle a person to patent under the Homestead laws is reduced from 5 to 3 years and the period within which a homestead entry may be completed is reduced from 7 to 5 years. The new law requires the claimant to 
cultivate not less than $1 / 16$ of the area of his entry beginning with the second year of entry and not less than $1 / 8$ beginning with the third year and until final proof, except that in the case of the enlarged Homestead laws, double the areas given are required. On a 160-acre claim, therefore, it is required that $1 / 8$ or 20 acres be under cultivation. A mere breaking of the soil does not meet the requirements of the statute, but such breaking of the soil must be accompanied by planting and sowing of seed and tillage for a crop other than native grasses. The period within which the cultivation should be made is reckoned from the date of the entry. The Secretary of the Interior, however, is authorized upon a satisfactory showing therefor to reduce the required area of cultivation on account of financial disabilities or misfortunes of the entryman or on account of special physical and climatic conditions of the land which make cultivation difficult. The entryman must establish an actual residence upon the land entered, 6 months after the date of the entry. After the establishment of residence the entryman is permitted to be absent from the land for one continuous period of not more than 5 months in each year following. He must also file 
at the local Land Office notice of the beginning of such intended absence.

The Mining Laros. Mineral deposits within National Forests are open to development exactly as on unreserved public land. A prospector can go anywhere he chooses and stake a claim wherever he finds any evidences of valuable minerals. The only restriction is that mining claims must be bona fide ones and not taken up for the purpose of acquiring valuable timber or a town or a water power site, or to monopolize the water supply of a stock range. Prospectors may obtain a certain amount of National Forest timber free of charge to be used in developing their claims. More than 500 mining claims are patented within the National Forests every fiscal year.

A good example of mining claims located for fraudulent purposes were those located on the rim and sides of the Grand Canyon in Arizona to prevent the people from gaining free access to the canyon and make them pay to enter it. These claims were shown to be fraudulent since no deposits of any kind were ever found on them. They were canceled by the higher courts and the land reverted to the people. 
Coal-Land Laws. Coal lands are mineral lands and as such are subject to entry the same as other mineral lands in the National Forests.

ADMINISTRATIVE USE OF NATIONAL FOREST LANDS

Lands within National Forests may be selected for administrative uses such as Supervisor's and Ranger's headquarters, gardens, pastures, corrals, planting or nursery sites or rights-of-way. These administrative sites are necessary for the present and probable future requirements of the Forest Service for fire protection and the transaction of business on the National Forests.

WATER POWER, TELEPHONE, TELEGRAPH, AND POWER TRANSMISSION LINES

Along the streams within the National Forests are many sites suitable for power development. These are open to occupancy for such purposes and have the advantage of being on streams whose headwaters are protected. The aggregate capacity of the water power sites on the National Forests is estimated at 12,000,000 horsepower.

'The Government does not permit the monopolization of power in any region or allow sites to be 


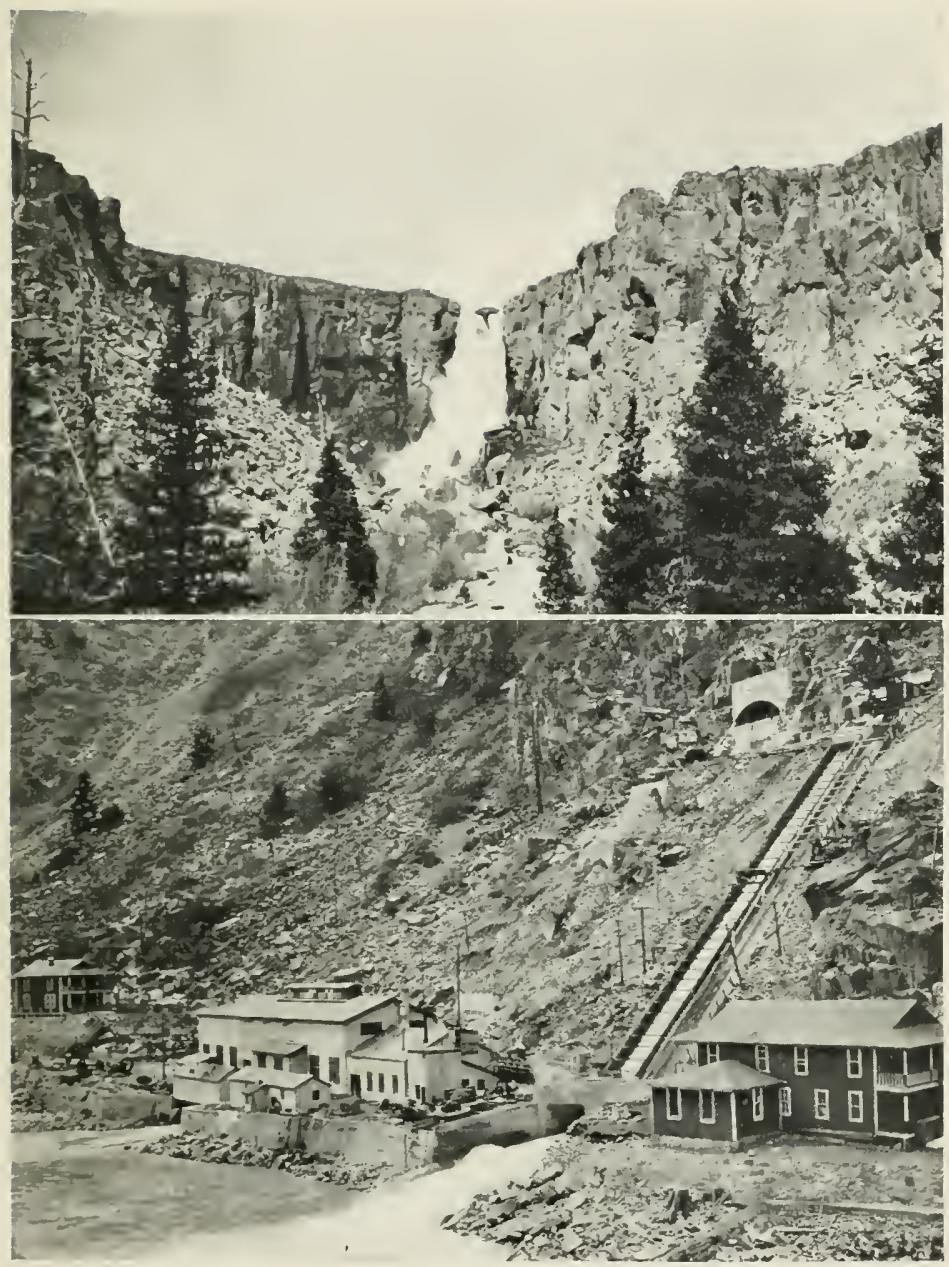

Figure 7 \% North Clear Creek Falls, Rio Grande National Forest, Colorado. The National Forests eontain about one-third of all the potential water-power resources of the ['nited States.

Figure 78. The power plant of the Colorado Power Company, on the Grand River, Holy Cross National Forest, Colorado, Every fiscal year there is a substantial inerease in water power development on the National Forests. 



\section{NATIONAL FOREST RESOURCES 231}

held for speculative purposes. The objects of the regulations are to secure prompt and full development and to obtain a reasonable compensation for the use of the land occupied and the beneficial protection given the watershed.

Permits for power development on the National Forests usually run for a term of 50 years and may be renewed at their expiration upon compliance with the regulations then existing. Such permits, while granting liberal terms to applicants, contain ample provision for the protection of the public interests.

Applications for power permits are filed with the District Forester of the Forest Service District in which the desired site is located. Preliminary permits are issued to protect an applicant's priority against subsequent applicants until he has had an opportunity to study the proper location and design of the project and to obtain the data necessary for the final application. Operation is allowed under the final permit only. The permittee is required to pay an annual rental charge under the preliminary and final power permits and definite periods are specified for the filing of the final application, beginning of construction and of operation. 
The rental charges are nominal in amount, the maximum being about $1 / 16$ of a cent per kilowatt hour. The amount of annual payment for transmission lines is $\$ 5.00$ for each mile or fraction thereof if National Forest land is crossed by the line. No rental charges are made for small power projects (under 100 horsepower capacity), or for transmission lines used in connection therewith, or for transmission lines which are part of a power project under permit or for any power project in which power is to be used by a municipal corporation for municipal purposes.

The Secretary of Agriculture has authority to permit the use of rights-of-way through the $\mathrm{Na}$ tional Forests for conduits, reservoirs, power plants, telephone and telegraph lines to be used for irrigation, mining, and domestic purposes and for the production and transmission of electric power. No rental charges are made for the telephone and telegraph rights-of-way, but the applicant must agree to furnish such facilities to Forest officers and to permit such reasonable use of its poles or lines as may be determined or agreed upon between the applicant and the District Forester. 

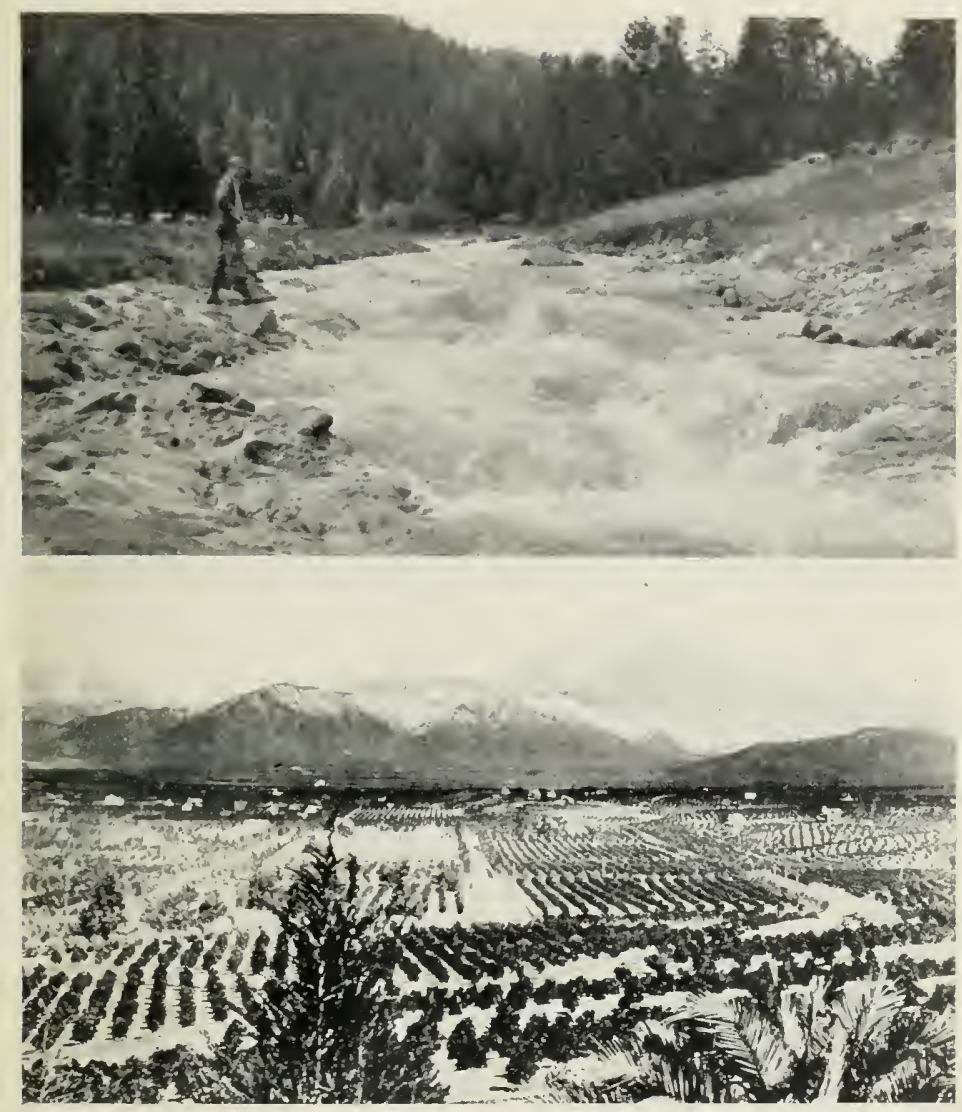

Figure 79. This is only one of the thousands of streams in the National Forests of the lifest capable of generating electric power. It has been estimated that over 40 per cent. of the water power resources of the western states are included in the $N$ ational Forests. Photo by the author.

Figure 80. View in the famous orange bett of San Bernardino County, California. These orchards depend absolutely upon irrigation. 'The watersheds from which the necessary water comes are in the National Forests and are protected by the Forest Service. Some of the smaller watersheds in these mountains are said to irrigate orchards valued at $\$ 10,000,000$. 



\title{
APPENDIX
}

\author{
TABLE OF LAND AREAS WITHIN THE NATIONAL \\ FOREST BOUNDARIES
}

June 30,1917

\begin{tabular}{|c|c|c|c|c|c|}
\hline State and Forest & 范 & $\begin{array}{c}\text { Headquarters } \\
\text { of } \\
\text { Forest } \\
\text { Supervisor }\end{array}$ & $\begin{array}{l}\text { National } \\
\text { Forest } \\
\text { Land } \\
\text { (acres) }\end{array}$ & $\begin{array}{l}\text { Patented } \\
\text { and other } \\
\text { lands } \\
\text { (acres) }\end{array}$ & $\begin{array}{l}\text { Total } \\
\text { area } \\
\text { (acres) }\end{array}$ \\
\hline \multicolumn{6}{|l|}{ ALASKA } \\
\hline Chugach & 6 & Ketchikan & $5,418,753$ & $113,68: 2$ & $5,532,435$ \\
\hline Tongass & 6 & Ketchikan & $15,451,716$ & 29,284 & $15,481,000$ \\
\hline \multicolumn{6}{|l|}{ ARIZONA } \\
\hline Apache & 3 & Springerville & $1,182,782$ & 93,618 & $1,2 \tau 6,400$ \\
\hline Chiricahua 1 & 3 & Tucson & $348,15 \pi$ & 10,691 & 358,848 \\
\hline Coconino & 3 & Flagstaff & $1,601,598$ & $161,799^{\circ}$ & $1,763,397$ \\
\hline Coronado & 3 & Tucson & 959,304 & $39,6 \% 6$ & 998,980 \\
\hline Crook & 3 & Safford & 870,130 & 14,870 & 885,000 \\
\hline Dixie 1 & 4 & St. George, & & & \\
\hline Kaibab & 4 & Kanab, Utah & $1,072,375$ & 525 & $1,072,900$ \\
\hline Manzano 1 & 3 & $\begin{array}{l}\text { Albuquerque, } \\
\text { N. M. }\end{array}$ & 27,708 & 29,724 & \\
\hline Prescott & 3 & Prescott & $1,433,366$ & 186,589 & $1,619,955$ \\
\hline Sitgreaves & 3 & Snowflake & 659,337 & 234,883 & 893,720 \\
\hline Tonto & 3 & Roosevelt & $1,994,239$ & 39,521 & $9,033,760$ \\
\hline Tusayan & 3 & Williams & $1,602,750$ & 186,068 & $1,788,818$ \\
\hline $\begin{array}{l}\text { Arkans } \\
\text { Ozark }\end{array}$ & 7 & $\begin{array}{l}\text { Hot Spri } \\
\text { Harrison }\end{array}$ & $\begin{array}{l}020,1+0 \\
291,840\end{array}$ & $\begin{array}{l}331,0+4 \\
23 \tau, 338\end{array}$ & \\
\hline \multicolumn{6}{|l|}{ CALIFORNIA } \\
\hline Angeles & 5 & Los Angeles & 820,980 & 240,723 & $1,061,703$ \\
\hline California & 5 & Oriental & $80 \tau, 444$ & 255,178 & $1,062,622$ \\
\hline Cleveland & 5 & Escondido & $54 \pi, 981$ & 265,635 & 813,616 \\
\hline Crater 1 & 6 & Medford, Ore. & 46,977 & 10,045 & 57,022 \\
\hline Eldorado 1 & 5 & Placerville & $549,39 \approx$ & 286,408 & 835,800 \\
\hline Inyo 1 & 5 & Bishop & $1,269,980$ & $6 \tau, 800$ & $1,337,780$ \\
\hline Klamath 1 & 5 & Yreka & $1,470,841$ & 263,824 & $1,734,665$ \\
\hline Lassen & 5 & Red Bluff & 936,877 & 384,466 & $1,321,343$ \\
\hline Modoc & 5 & Alturas & $1,182,986$ & $399,8 \pi 3$ & $1,532,859$ \\
\hline
\end{tabular}

1 Area of National Forest in nore than one State. 
TABLE OF LAND AREAS-Continued

\begin{tabular}{|c|c|c|c|c|c|}
\hline State and Forest & 点 & $\begin{array}{l}\text { Headquarters } \\
\text { of } \\
\text { Forest } \\
\text { Supervisor }\end{array}$ & $\begin{array}{l}\text { National } \\
\text { Forest } \\
\text { Land } \\
\text { (acres) }\end{array}$ & $\begin{array}{l}\text { Patented } \\
\text { and other } \\
\text { lands } \\
\text { (acres) }\end{array}$ & $\begin{array}{l}\text { Total } \\
\text { area } \\
\text { (acres) }\end{array}$ \\
\hline Mono 1 & 5 & $\begin{array}{l}\text { Gardnerville, } \\
\text { Nev. }\end{array}$ & 784,620 & 90,241 & 874,861 \\
\hline Monterey & 5 & King City & 316,058 & 44,436 & 360,494 \\
\hline Plumas & 5 & Quincy & $1,144,835$ & 288,025 & $1,432,860$ \\
\hline $\begin{array}{l}\text { Santa Bar- } \\
\text { bara }\end{array}$ & 5 & Santa Barbara & $1,688,571$ & 239,723 & $1,928,294$ \\
\hline Sequoia & 5 & Bakersfield & $2,194,926$ & 274,344 & $2,469,270$ \\
\hline Shasta & 5 & Sisson & 803,448 & 783,432 & $1,586,880$ \\
\hline Sierra & 5 & Northfork & $1,489,934$ & 172,626 & $1,662,560$ \\
\hline Siskiyou 1 & 6 & $\begin{array}{l}\text { Grants Pass, } \\
\text { Ore. }\end{array}$ & 069 & 52,726 & 401,795 \\
\hline Stanislaus & 5 & Sonora & 810,399 & 294,013 & $1,104,412$ \\
\hline Tahoe & 5 & Nevada City & 542,226 & 666,851 & $1,209,077$ \\
\hline Trinity & 5 & Weaverville & $1,430,547$ & 315,600 & $1,746,147$ \\
\hline COLORADO & & & & & \\
\hline Arapaho & $\mathcal{2}$ & $\begin{array}{l}\text { Hot Sulphur } \\
\text { Springs }\end{array}$ & 634,903 & 46,371 & 681,274 \\
\hline Battlement & 2 & Collbran & 651,927 & 26,113 & 677,340 \\
\hline Cochetopa & $\tilde{z}$ & Saguache & 905,723 & 24,497 & 930,220 \\
\hline Colorado & $\tilde{\mathcal{Q}}$ & Fort Collins & 847,328 & 302,266 & $1,149,594$ \\
\hline Durango & 2 & Durango & 614,129 & 89,871 & 704,000 \\
\hline Gunnison & $\tilde{2}$ & Gunnison & 908,055 & 43,255 & 951,310 \\
\hline Hayden 1 & $\tilde{2}$ & $\begin{array}{l}\text { Encampment, } \\
\text { Wyo. }\end{array}$ & 65,598 & 6,402 & 72,000 \\
\hline Holy Cross & 2 & $\begin{array}{r}\text { Glenwood } \\
\text { Springs }\end{array}$ & 576,905 & 28,795 & 605,700 \\
\hline La Sal 1 & 4 & Moab, Utah & 27,444 & 176 & 27,620 \\
\hline Leadville & $\mathcal{2}$ & Leadville & 934,017 & 122,503 & $1,056,520$ \\
\hline Montezuma & $\boldsymbol{2}$ & Mancos & 700,082 & 112,018 & 812,100 \\
\hline Pike & 2 & Denver & $1,080,381$ & 175,731 & $1,256,112$ \\
\hline Rio Grande & $\tilde{2}$ & Monte Vista & $1,136,884$ & 84,256 & $1,221,140$ \\
\hline Routt & 2 & $\begin{array}{l}\text { Steamboat } \\
\text { Springs }\end{array}$ & 833,459 & 86,487 & 919,946 \\
\hline San Isabel & 2 & Westcliffe & 598,912 & 52,288 & 651,200 \\
\hline San Juan & 2 & Pagosa Spgs. & 617,995 & 127,005 & 745,000 \\
\hline Sopris & $\tilde{\mathcal{Q}}$ & As & 596,986 & 59,014 & 656,000 \\
\hline Uncampahgre & $\tilde{\mathcal{2}}$ & Delta & 790,349 & 77,511 & 867,860 \\
\hline White River & $\mathcal{Z}$ & Meeker & 848,018 & 23,012 & 871,030 \\
\hline FLORIDA & & & & & \\
\hline $\begin{array}{l}\text { Florida } \\
\text { IDAHO }\end{array}$ & 7 & Pensacola & 308,268 & 367,152 & 675,420 \\
\hline $\begin{array}{l}\text { IDAHO } \\
\text { Boise }\end{array}$ & 4 & Boise & 1,0 & 173 & $1,118,114$ \\
\hline Cache 1 & 4 & Logan, Utah & 513,617 & 31,447 & 545,064 \\
\hline
\end{tabular}

1 Area of National Forest in more than one State. 
TABLE OF LAND AREAS-Continued

\begin{tabular}{|c|c|c|c|c|c|}
\hline State and Forest & 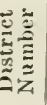 & $\begin{array}{c}\text { Headquarters } \\
\text { of } \\
\text { Forest } \\
\text { Supervisor }\end{array}$ & $\begin{array}{l}\text { National } \\
\text { Forest } \\
\text { Land } \\
\text { (acres) }\end{array}$ & $\begin{array}{l}\text { Patented } \\
\text { and other } \\
\text { lands } \\
\text { (acres) }\end{array}$ & $\begin{array}{l}\text { Total } \\
\text { area } \\
\text { (acres) }\end{array}$ \\
\hline Caribou 1 & 4 & Montpelier & 681,540 & 30,090 & 711,630 \\
\hline Challis & 4 & Challis & $1,259,237$ & 10,753 & $1,269,990$ \\
\hline $\begin{array}{l}\text { Clearwater } \\
\text { Coeur }\end{array}$ & 1 & Orofino & 785,103 & 122,743 & 907,846 \\
\hline d'Alene & 1 & Coeur d'Alene & 662,611 & 127,623 & $\tau 90,234$ \\
\hline Idaho & 4 & McCall & $1,193,439$ & 15,841 & $1,209,280$ \\
\hline Kaniksu 1 & 1 & $\begin{array}{c}\text { Newport, } \\
\text { Wash. }\end{array}$ & 198,757 & 260,220 & $458,9 \tau \pi$ \\
\hline Lemhi & 4 & Mackay & $1,095,924$ & 4,638 & $1,100,562$ \\
\hline Minidoka 1 & 4 & Oakley & 509,536 & 21,584 & 531,120 \\
\hline Nezperce & 1 & Grangeville & $1,624,582$ & 41,497 & $1,666,079$ \\
\hline Palisade 1 & 4 & St. Anthony & 283,495 & $9,8 \approx 0$ & 293,315 \\
\hline Payette & 4 & Emmett & 831,926 & 31,748 & 863,674 \\
\hline Pend Oreille & 1 & Sandpoint & $6 \tau 6,014$ & 198,724 & 874,738 \\
\hline St. Joe & 1 & St. Maries & 493,925 & 481,743 & 975,668 \\
\hline Salmon & 4. & Salmon & $1,621,70 \tau$ & 21,653 & $1,6+3,360$ \\
\hline Sawtooth & 4 & Hailey & $1,203,387$ & 16,743 & $1,220,130$ \\
\hline Selway & 1 & Kooskia & $1,693, \tilde{\pi} 11$ & 108,289 & $1,802,000$ \\
\hline Targhee 1 & 4 & St. Anthony & 283,495 & 9,820 & 293,315 \\
\hline Weiser & 4 & Weiser & 562,609 & 98,291 & 660,900 \\
\hline $\begin{array}{l}\text { MICHIGAN. } \\
\text { Michigan }\end{array}$ & 2 & East Tawas & 89,466 & 74.412 & 163878 \\
\hline MINNESOTA & & & & & \\
\hline Minnesota & $\stackrel{2}{2}$ & Cass Lake & 190,602 & 121,874 & 312,476 \\
\hline Superior & 2 & Ely & 857,255 & 411,283 & $1,268,538$ \\
\hline MONTANA & & & & & \\
\hline Absaroka & 1 & Livingston & 842,467 & 145,243 & 987,710 \\
\hline Beartooth & 1 & Billings & 662,537 & 19,393 & 681,930 \\
\hline Beaverhead & 1 & Dillon & $1,337,223$ & 27,777 & $1,365,000$ \\
\hline Bitterroot & 1 & Missoula & $1,047,012$ & 108,856 & $1,155,868$ \\
\hline Blackfeet & 1 & Kalispell & $865,0 \% 7$ & 202,013 & $1,067,090$ \\
\hline Cabinet & 1 & Thompson & & & \\
\hline & & Falls & 830,676 & 195,874 & $1,026,550$ \\
\hline Custer & 1 & Miles City & 428,922 & $83, \$ 88$ & 512,810 \\
\hline Deerlodge & 1 & Anaconda & 833,178 & 130,822 & 964,000 \\
\hline Flathead & 1 & Kalispell & $1,802,905$ & 285,815 & $2,088,720$ \\
\hline Gallatin & 1 & Bozeman & 564,855 & $344,5 \div 5$ & 909,430 \\
\hline Helena & 1 & Helena & 687,983 & 232,497 & $9: 20,480$ \\
\hline Jefferson & 1 & Great Falls & $1,039,766$ & 135,919 & $1,175,685$ \\
\hline $\begin{array}{l}\text { Kootenai } \\
\text { Lewis and }\end{array}$ & 1 & Libby & $1,336,061$ & 287,279 & $1,6: 23,340$ \\
\hline Clark & 1 & Chouteau & 811,161 & 15,199 & 826,360 \\
\hline Lolo & I & Missoula & $850,67 \tau$ & 330,341 & $1,181,018$ \\
\hline
\end{tabular}

1 Area of National Forest in more than one State. 


\section{OUR NATIONAL FORESTS}

TABLE OF LAND AREAS-Continued

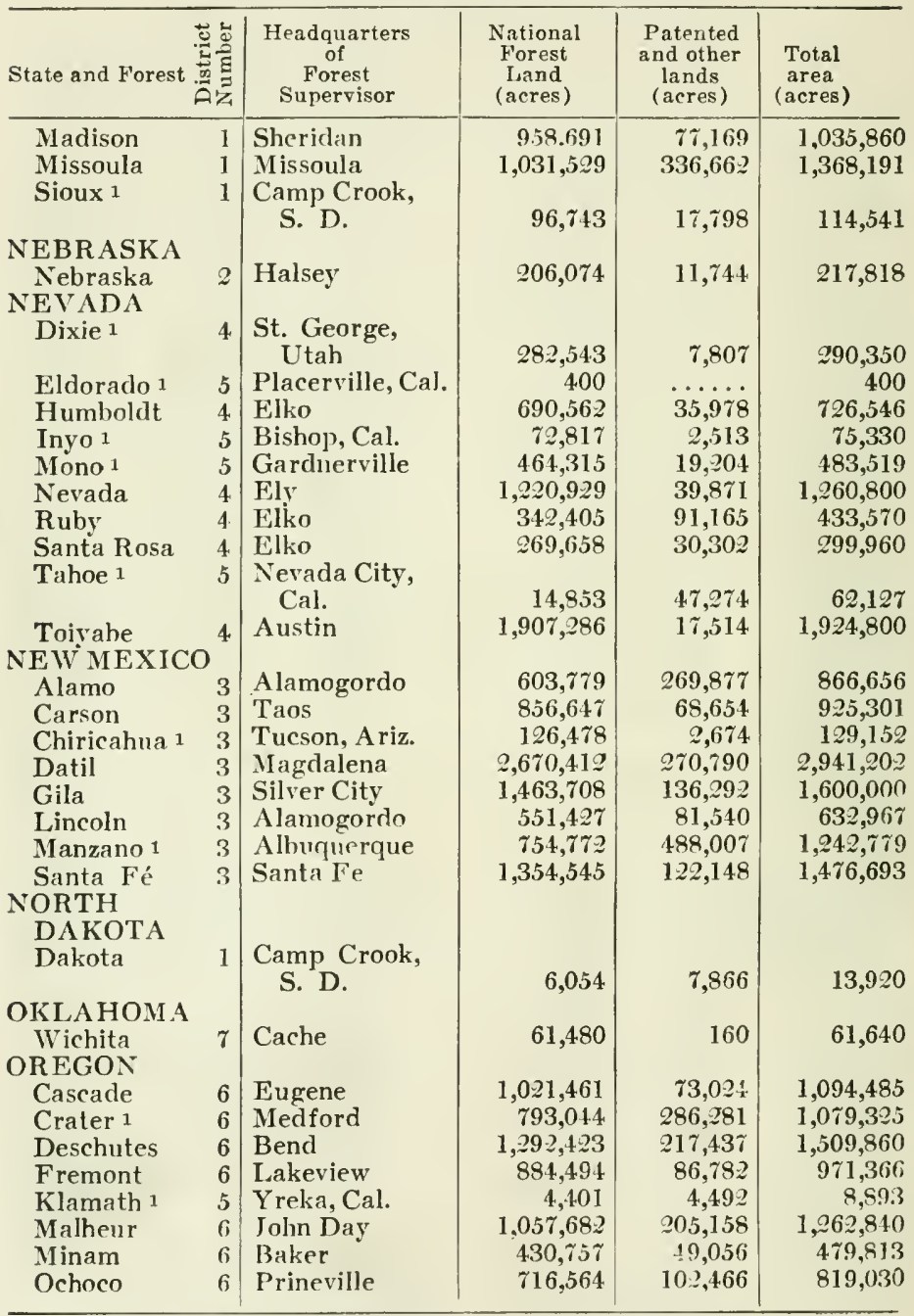

1 Area of National Forest in more than one State, 
TABLE OF LAND AREAS-Continued

\begin{tabular}{|c|c|c|c|c|c|}
\hline State and Forest & 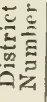 & $\begin{array}{c}\text { Headquarters } \\
\text { of } \\
\text { Forest } \\
\text { Supervisor }\end{array}$ & $\begin{array}{c}\text { National } \\
\text { Forest } \\
\text { Land } \\
\text { (acres) }\end{array}$ & $\begin{array}{l}\text { Patented } \\
\text { and other } \\
\text { lands } \\
\text { (acres) }\end{array}$ & $\begin{array}{l}\text { Total } \\
\text { area } \\
\text { (acres) }\end{array}$ \\
\hline ()rcgon & 6 & Portland & $1,03 I, 9 \gtrsim 6$ & 108,994 & $1,140,920$ \\
\hline Santiam & 6 & Albany & $60 \%, 099$ & 112,881 & 719,983 \\
\hline Siskigou 1 & (j) & Grants Pass & $998,04$. & $2.5 \%, 206 \mathrm{i}$ & $1,255,250$ \\
\hline Siuslaw & 6 & Eugene & 514,178 & 989,263 & 833,441 \\
\hline Lmatilla & 6 & Pendleton & $48.5,786$ & 79,199 & $564,98.5$ \\
\hline Unupqua & 6 & Rosehurg & $1,011,097$ & 210,294 & $1,221,391$ \\
\hline II allowa & 6 & Wallowa & 961,601 & 104,810 & $1,069,411$ \\
\hline Wenaha & 6 & $\begin{array}{c}\text { Walla Walla, } \\
\text { Wash. }\end{array}$ & 425,504 & 36,540 & 461,954 \\
\hline $\begin{array}{c}\text { Whitman } \\
\text { PORTO RICO }\end{array}$ & 6 & Sumpter & 884,485 & 115,008 & 999,493 \\
\hline Luquillo & 7 & None & 12,443 & 53,507 & 65,950 \\
\hline $\begin{array}{l}\text { SOLTH } \\
\text { DА KOTA }\end{array}$ & & & & & \\
\hline $\begin{array}{l}\text { Black Hills } 1 \\
\text { Harney }\end{array}$ & $\begin{array}{l}2 \\
2\end{array}$ & $\begin{array}{l}\text { Deadwood } \\
\text { Custer }\end{array}$ & $\begin{array}{l}483,403 \\
548,854\end{array}$ & $\begin{array}{r}118,608 \\
79,093\end{array}$ & $\begin{array}{l}602,011 \\
627,947\end{array}$ \\
\hline Sioux 1 & 1 & Camp Crook & $75,5 \geq 4$ & 7,744 & 83,268 \\
\hline UTA H & & & & & \\
\hline Ashley 1 & 4 & Vernal & 982,493 & 9,607 & 992,100 \\
\hline Cache 1 & 4 & Logan & 265,594 & 53,987 & 319,581 \\
\hline Dixie 1 & 4 & St. George & 432,784 & 26,106 & 458,890 \\
\hline Fillmore & 4 & Ritchfield & $699,5 \% 9$ & 79,711 & $\tau 79,990$ \\
\hline Fishlake & 4 & Salina & 661,245 & 62,145 & 723,390 \\
\hline La Sal 1 & 4 & Moab & 519,384 & 16,986 & 535,670 \\
\hline Manti & 4 & Ephraim & 781,800 & 65,070 & 846,870 \\
\hline Minidoka 1 & 4 & Oakley, Idaho & $\tau 2,123$ & 20,157 & 92,280 \\
\hline Powell & 4 & Escalante & $68,9,927$ & 14,773 & 704,700 \\
\hline Sevier & 4 & Panguitch & 729,061 & 73,599 & 802,660 \\
\hline Uinta & 4 & Provo & 988,602 & $54,5.3,3$ & $1,043,135$ \\
\hline Wasatch & 4 & Salt Lake City & $60 \tau, 492$ & 56,913 & 664,405 \\
\hline W ASHINGTC & & & & & \\
\hline Chelan & 6 & Chelan & 677,129 & 46,681 & 724,110 \\
\hline Columbia & 6 & Portland, Ore. & 784,498 & 157,702 & 942,200 \\
\hline Colville & 6 & Republic & 754,886 & 61,114 & 816,000 \\
\hline Kaniksu 1 & 1 & Newport & $25 \tau, 859$ & 118,904 & $3 \div 6, \pi 63$ \\
\hline Okanogan & 6 & Okanogan & $1,486,325$ & 54,675 & $1,541,000$ \\
\hline Olympic & 1 & Olympia & $1,534,689$ & 117,311 & $1,652,000$ \\
\hline Rainier & 6 & Tacoma & $1,315,891$ & 245,579 & $1,561,4.70$ \\
\hline Snoqualmie & 6 & Seattle & 698,043 & 343,957 & $1,0 \pm 2,000$ \\
\hline Washington & 6 & Bellingham & $1,454,214$ & 35,786 & $1,490,000$ \\
\hline Wenaha 1 & 6 & Walla Walla & 313,434 & 8,397 & 321,831 \\
\hline Wenatchee & 6 & Leavenworth & 665,276 & 491,724 & $1,15 \tau, 000$ \\
\hline
\end{tabular}

1 Area of National Forest in more than one State. 
TABLE OF LAND AREAS-Continted

\begin{tabular}{|c|c|c|c|c|}
\hline State and Forest & $\begin{array}{c}\text { Headquarters } \\
\text { of } \\
\text { Forest } \\
\text { Supervisor }\end{array}$ & $\begin{array}{l}\text { National } \\
\text { Forest } \\
\text { Land } \\
\text { (acres) }\end{array}$ & $\begin{array}{l}\text { Patented } \\
\text { and other } \\
\text { lands } \\
\text { (acres) }\end{array}$ & $\begin{array}{l}\text { Total } \\
\text { area } \\
\text { (acres) }\end{array}$ \\
\hline \multicolumn{5}{|l|}{ WYOMING } \\
\hline Ashley 1 & 4 Vernal, Utah & $5,98 \pi$ & 73 & 6,060 \\
\hline Bighorn & 2 Sheridan & $1,119,725$ & 16,475 & $1,136,200$ \\
\hline Black Hills 1 & 2 Deadwood, S.D. & 144,759 & 34,362 & 179,121 \\
\hline Bridger & 2 Pincdale & 710,570 & 7,407 & 717,977 \\
\hline Caribou 1 & $\begin{array}{c}\text { 4. Montpelier, } \\
\text { Idaho }\end{array}$ & 6,5 & 813 & 7,360 \\
\hline Hayden 1 & 2 Encampment & 322,175 & 43,445 & 365,620 \\
\hline Medicine Bow & 2 Laramie & 469,786 & 41,596 & 511,382 \\
\hline Palisade 1 & $\begin{array}{l}4 \text { St. Anthony, } \\
\text { Idaho }\end{array}$ & 950 & 3 & 253,620 \\
\hline Shoshone & 2 Cody & $1,5 \tau 6,043$ & $32,95 \pi$ & $1,609,000$ \\
\hline 'Targhee 1 & $\begin{array}{l}4 \text { St. Anthony, } \\
\text { Idaho }\end{array}$ & 84,970 & 480 & 85,450 \\
\hline Teton & 4 Jackson & $1,922,9,47$ & 48,245 & $1,9 \pi 1,192$ \\
\hline Washakie & 2 Lander & $852,6.5 .3$ & 12,220 & 864,873 \\
\hline Wyoming & 4. Afton, & 899,980 & $12,0 \approx 0$ & 912,000 \\
\hline \multicolumn{5}{|c|}{ Aggregate for the 147 National } \\
\hline & . & $155,166,(1) 19$ & $21,085,341$ & $176,202,100$ \\
\hline
\end{tabular}

1 Area of National Forest in more than one State. 





\section{Date Due}

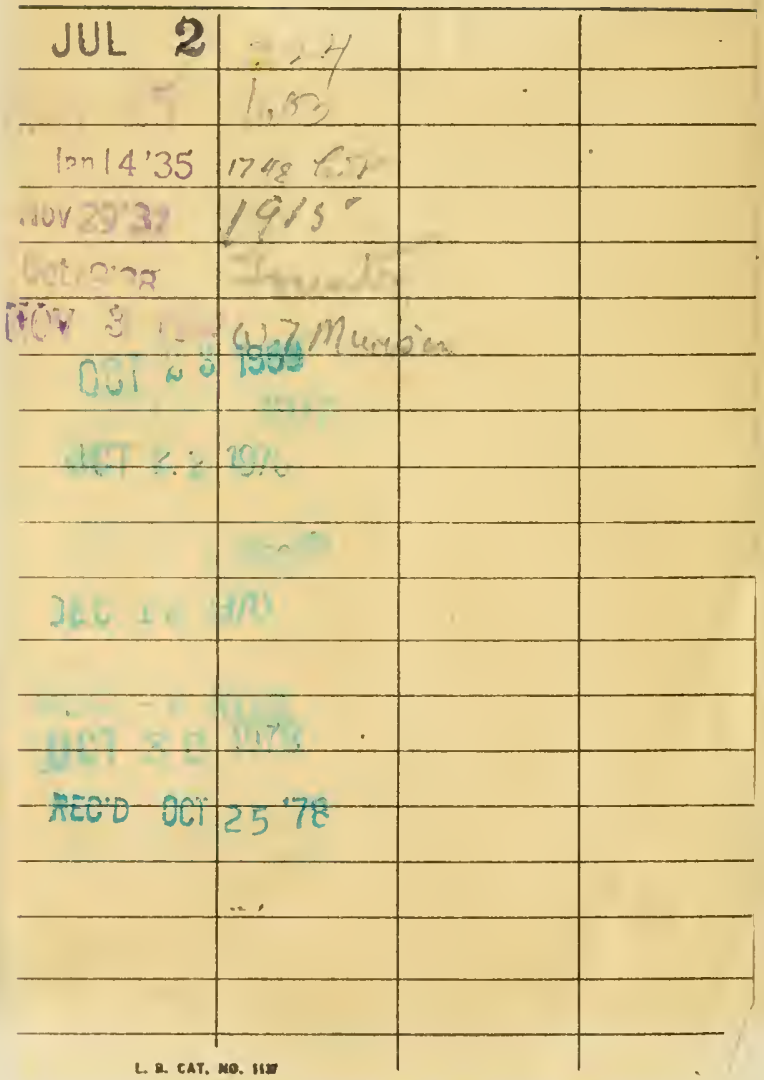




\section{AGRICUILTURE FORESTRY LIBRARY}

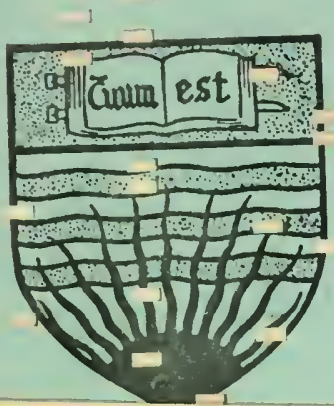

\section{FDRESTRY}




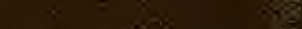

$$
10
$$

$$
\begin{aligned}
& = \\
& 80 \%
\end{aligned}
$$

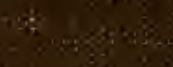

4. $808 \times 8 \times=$

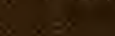

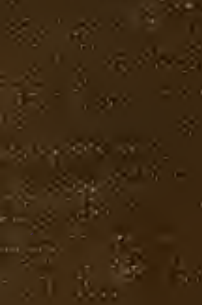

(1) $\$, \$ 10$

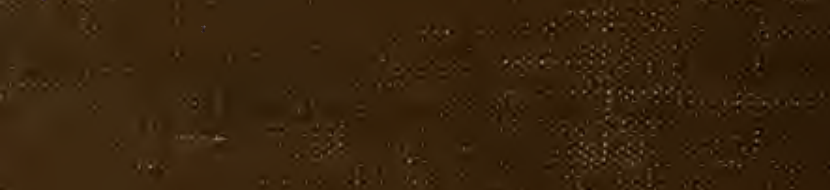

3. $-8 \times 2009$

a then 34

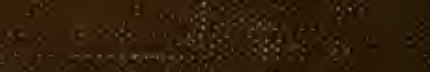

$6 \%$

6.8.8.

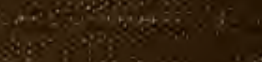

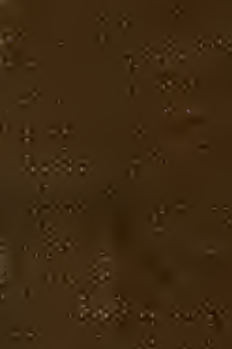

45 a
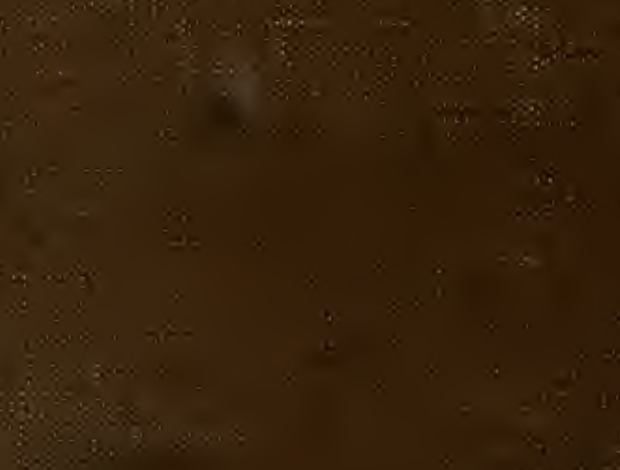

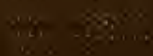

8

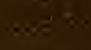

$=+\infty \times 8 \%$

$x^{2}$

$\$ 8$

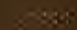

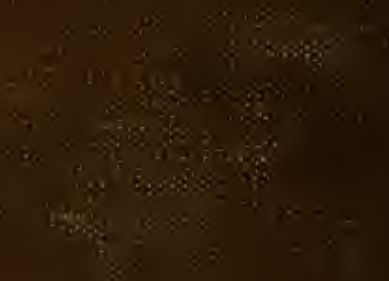

60 